\title{
Professionsföretagare
}

\section{I skärningspunkten mellan småföretagande, profession och genus}

\author{
Jenny Appelkvist
}

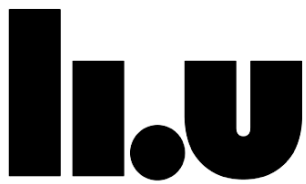

LINKÖPINGS UNIVERSITET

Linköping Studies in Arts and Science No. 697

Linköpings Universitet, Institutionen för ekonomisk och industriell utveckling

Linköping 2016 
Linköping Studies in Arts and Science • No. 697

Vid filosofiska fakulteten vid Linköpings universitet bedrivs forskning och ges forskarutbildning med utgångspunkt från breda problemområden. Forskningen är organiserad i mångvetenskapliga forskningsmiljöer och forskarutbildningen huvudsakligen i forskarskolor. Gemensamt ger de ut serien Linköping Studies in Arts and Science. Denna avhandling kommer från Företagsekonomi vid Institutionen för ekonomisk och industriell utveckling

Distribueras av:

Institutionen för ekonomisk och industriell utveckling Linköpings universitet 58183 Linköping

Jenny Appelkvist Professionsföretagare

I skärningspunkten mellan småföretagande, profession och genus

Upplaga 1:1

ISBN 978-91-7685-675-8

ISSN 0282-9800

(C)Jenny Appelkvist

Institutionen för ekonomisk och industriell utveckling 2016

Tryckeri: LiU-tryck, Linköping 


\section{"Nolite te bastardes carborundorum. \\ Don't let the bastards grind you down."}

[Margaret Atwood; The Handmaids Tale]

Till Farmor 

Avhandlingens ledmotiv:

“Well I won't back down, no I won't back down You could stand me up at the gates of hell

But I won't back down

Gonna stand my ground, won't be turned around And I'll keep this world from draggin' me down Gonna stand my ground and I won't back down"

Johnny Cash - American III: Solitary Man 



\section{Sammanfattning}

Den här avhandlingen handlar om kvinnors företagande i en profession stadd i förändring. Flera professioner i Sverige, men också internationellt, präglas av en ökad andel kvinnor men även av de strukturella omvandlingar som under 1900-talet lett från ett industri- till ett tjänstesamhälle. Ett ökat småföretagande är en annan förändring som uppkommit under senare år.

I föreliggande studie beskrivs och analyseras kvinnors företagande inom en profession utifrån vad som sker i skärningspunkten mellan företagande, profession och genus. Ett tydligt exempel i Sverige på en profession stadd i förändring är veterinärprofessionen som de senaste 50 åren genomgått en rad förändringar.

Den teoretiska referensramen består av en kombination av teorier om småföretagande, profession och genus. Det empiriska materialet består av intervjuer med samtliga veterinärer som är företagare och kvinnor i Östergötland.

I avhandlingen myntas begreppet professionsföretagare med avsikt att synliggöra samspelet mellan företagande och profession. Studiens resultat visar att professionen i många fall prioriteras framför företagandet. Professionsföretagarna gör genus på skilda sätt i olika dimensioner och på olika nivåer. Det är stabilitet i hur genus görs på generell nivå medan genus på specifik nivå görs på ett sätt som i vissa dimensioner utmanar genussystemet. Även om stabilitet är dominerande visar studien exempel på att professionsföretagande skapar förutsättningar för vissa glipor i genussystemets mönster. 



\section{Förord}

Under tiden som jag har arbetat med den här avhandlingen så har livet fortsatt att gå sin gilla gång. Det har en tendens att göra det, det blir ingen paus bara för att en avhandling ska skrivas. Det har varit både glädjeämnen och sorger, brutalt utportionerade utan hänsyn till att syftet ska sättas eller att analysen är inne i ett kritiskt skede. Under den här tiden har jag återkommit till några ledord för att hålla den värsta doktorandångesten stången; "Det är en forskarUtbildning" samt "Good enough". Jag tänker inte påstå att jag lyckats hålla fast i dessa ledord hela tiden - jag har snubblat och glömt och tvivlat. Jag har glömt att syftet med det jag gjort varit att utbilda mig till forskare. Istället har jag krävt av mig själv att vara fullfjädrad från början. Jag har sökt perfektion. Jag har glömt att det ibland är viktigt att sätta gränser för saker och ting. Texter alltid kan förbättras men någon gång måste punkt sättas. För vad är annars vitsen om texten aldrig blir läst?

Vad jag vill säga med detta är att boken du ser framför dig inte är mitt livsverk. Det är resultatet av en forskarutbildning och en, i det stora perspektivet, liten del av mitt liv. Därmed inte sagt att jag inte är stolt och glad i denna stund. Tvärtom så svävar jag på moln när jag nu håller den färdiga produkten i mina händer. Det har varit en stor utmaning och jag har lärt mig mycket på vägen - om att skriva och forska men också om livet och om mig själv. Jag har framför allt lärt mig att jag är stark, men även att det mesta har en tendens att ordna sig. En smärre förändring av en dialog från filmen Shakespeare In Love där "the theatre business" byts mot "doing a PhD" illustrerar detta förhållande:

Philip Henslowe: $\quad$ Mr. Fennyman, allow me to explain about doing a PhD. The natural condition is one of insurmountable obstacles on the road to imminent disaster.

Hugh Fennyman: So what do we do?

Philip Henslowe: Nothing. Strangely enough, it all turns out well.

Hugh Fennyman: How?

Philip Henslowe: I I don't know. It's a mystery. 
Jag är i denna stund djupt tacksam för allt stöd jag har fått under min tid som doktorand. Det är många som ska tackas och jag ämnar göra det ordentligt!

Mina handledare; Malin Tillmar, Elisabeth Sundin och Lena Högberg - tre starka och kloka kvinnor - har stått mig bi i vått och torrt. Ni är var och en värda ett alldeles eget tack:

Malin, du har betytt otroligt mycket för mig på den här resan. Tack för allt ditt stöd och inte minst din tro på mig, även då min egen stundtals sviktade! Tack för din värme och din humor.

Elisabeth, din entusiasm och vetgirighet är en inspiration för oss alla. Dina kloka kommentarer har mången gång givit mig energi att fortsätta kämpa. Tack!

Lena, du har lyckats med att gå från att vara doktorandkollega till chef och bihandledare under åren vi känt varandra. Alltid lika stöttande oavsett din roll. Tack!

Forskargruppen MORE har varit en hemvist för mig under de här åren. Här har utöver mina kloka handledare även Olga Yttermyr, Birgitta Sköld, Vivi Hallström och Hanna Antonsson ingått. Tack för alla spännande samtal vi delat!

Tack även till Anette Hallin för hennes kloka kommentarer vid slutseminariet. Jag fick även värdefulla kommentarer i slutskedet av Magnus Klofsten - Tack!

Tack till avdelningen Företagsekonomi som delvis finansierat mina sista år som doktorand. Samvaron med kollegorna på fredagsfikan men även i seminarier och små pratstunder i korridoren har gjort vår del av A-korridoren till en trivsam plats. Särskilt tack till mina fantastiska föregångare och inspirationskällor men även vänner; Cecilia Enberg och Marie Bengtsson. Ni har betytt så mycket. Jag ser fram emot fler bioupplevelser tillsammans med er!

Johanna Nählinder, du har blivit en god vän och mentor alltsedan du kommenterade mitt manus på vägen mot licentiaten. Jag har uppskattat våra samtal om känslor, släktforskning och böcker. Tack för allt ditt stöd under den här tiden!

Ett särskilt tack till doktorandkollegorna för gemenskapen och skratten: Svjetlana Pantic Dragisic, Josefin Rasmussen, Christopher Danielsson, Hugo Guyader, Linus Axén, Anja Sorokina, Johanna Sylvander, Aliaksei Kazlou, David Andersson, Vivi Hallström, Victor Aichagui, Susan Riedel. Ni är fantastiska!

Ett särskilt tack också till alla och envar som stöttat min process genom sponsring med finkaffe under våren 2016. Det har värmt och gett energi på mer än ett sätt. Jag för det vidare. 
Mina underbara vänner som stått vid min sida i med- och motgång: Hanna Mattsson, Elisabeth Borg, Lisa Melander, Christina Maack, Katharina Baer - Tack! Ni är så värdefulla för mig.

Tack mamma och pappa för all hundpassning och goda middagar. Det har inte alltid varit lätt att förklara doktorerandets, ibland nyckfulla, tillvaro men ni har hela tiden funnits där med både tröst och uppmuntran.

Tack älskade Stellan för ditt stöd, uppmuntran och förmåga att få mig att skratta. Du är och förblir min klippa.

Jenny

Linköping i september 2016

"Mod är inte alltid högljutt. Ibland är mod den lilla rösten i slutet av dagen som säger: 'Jag försöker igen imorgon.'” 



\section{Innehållsförteckning}

\section{Del 1}

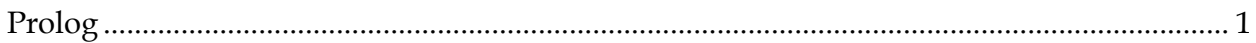

Kapitel 1: Kvinnors företagande i en profession stadd i förändring ........................................ 3

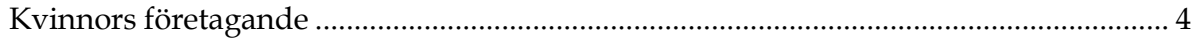

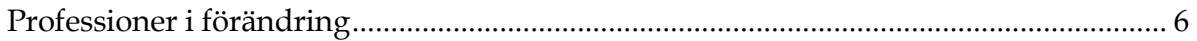

I skärningspunkten mellan småföretagande, profession och genus .................................. 7

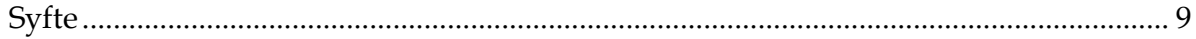

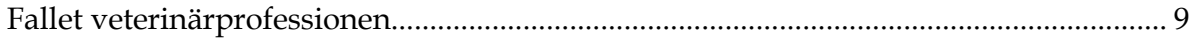

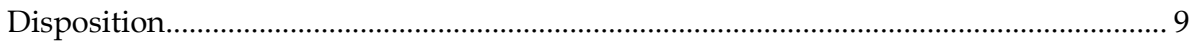

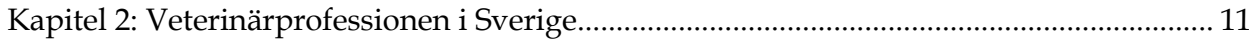

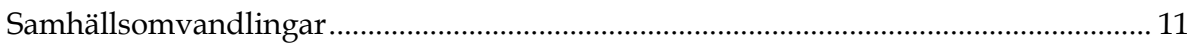

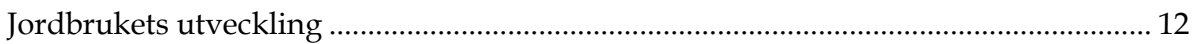

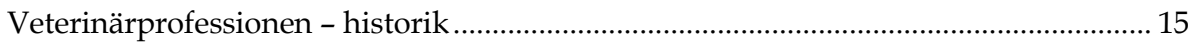

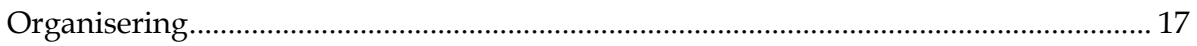

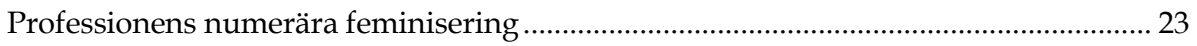

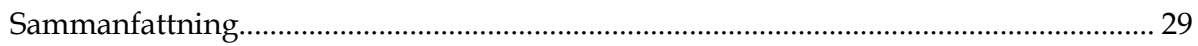

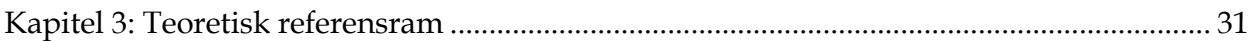

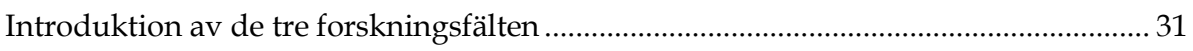

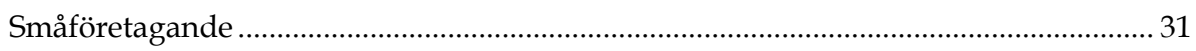

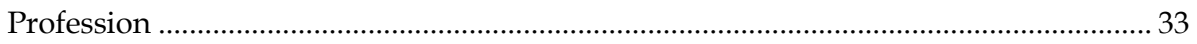

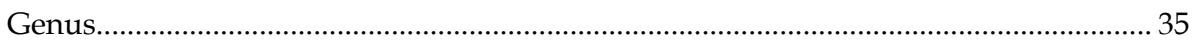

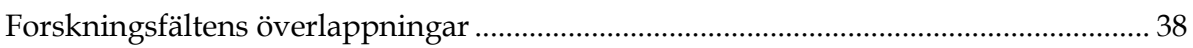

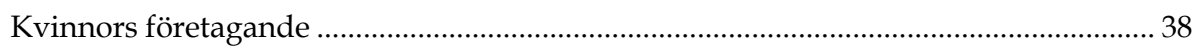

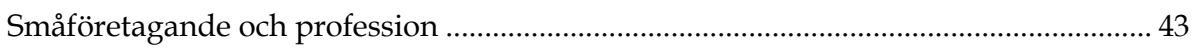

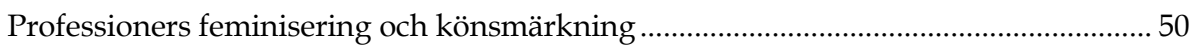

I skärningspunkten mellan småföretagande, profession och genus ................................. 56

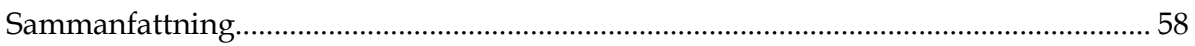

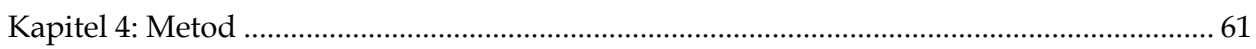

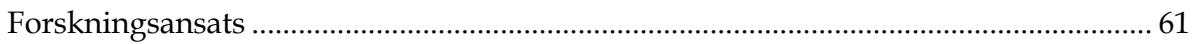




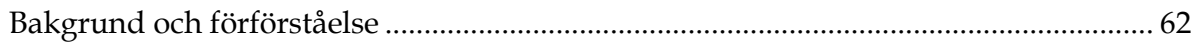

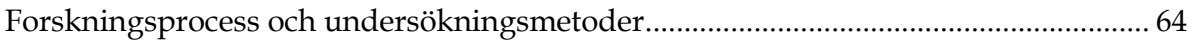

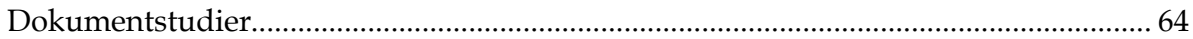

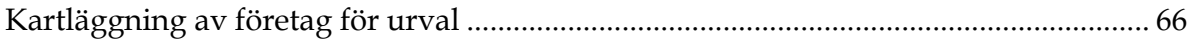

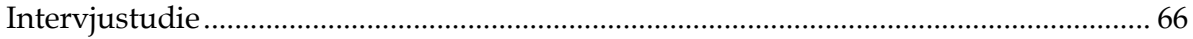

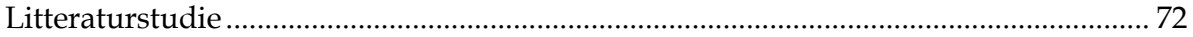

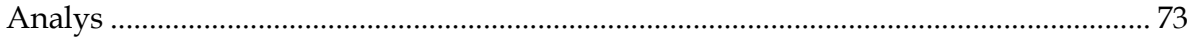

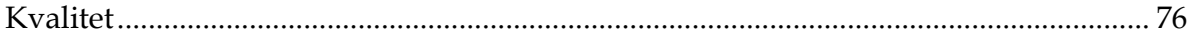

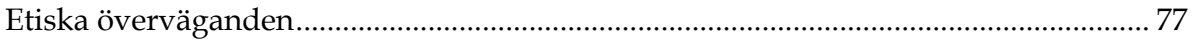

\section{Del 2}

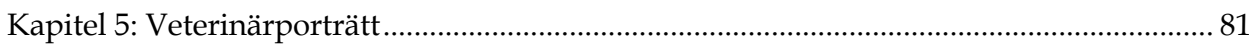

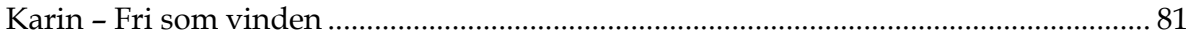

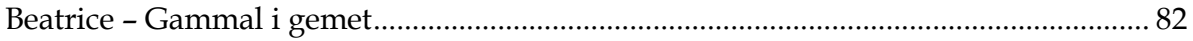

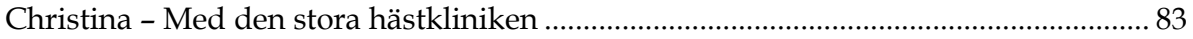

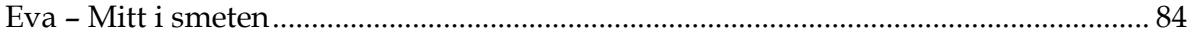

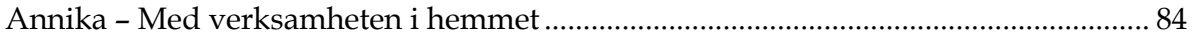

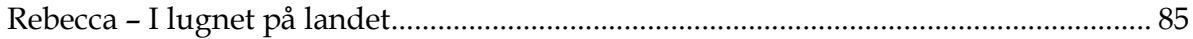

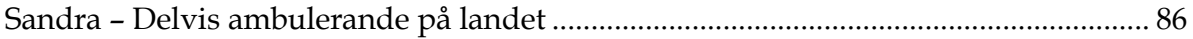

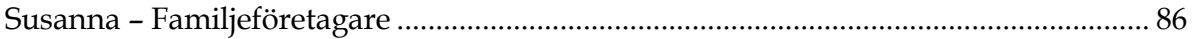

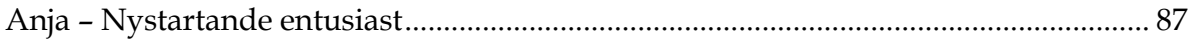

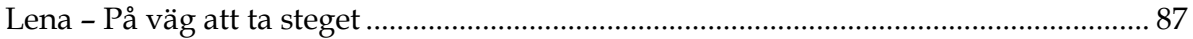

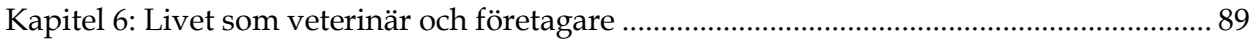

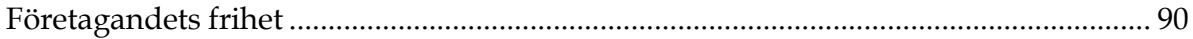

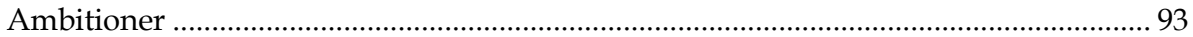

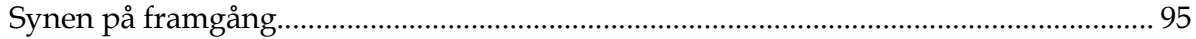

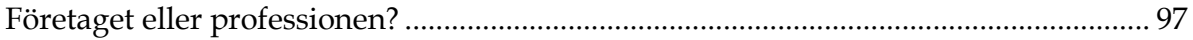

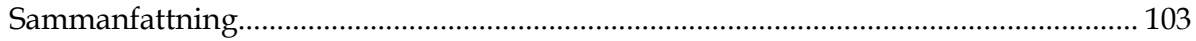

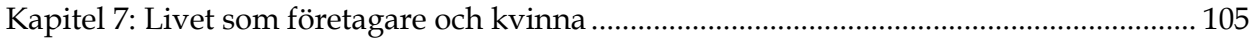

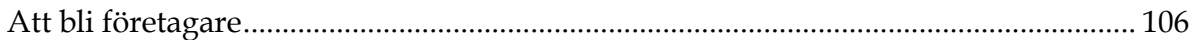

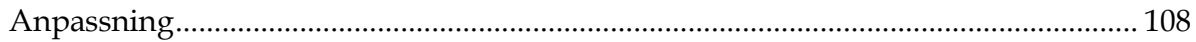

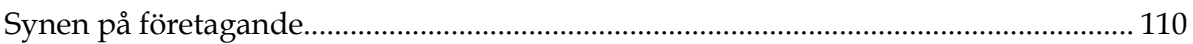

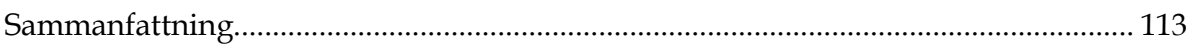

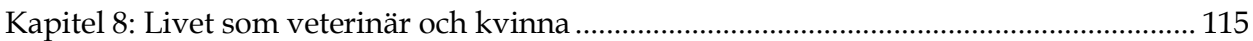

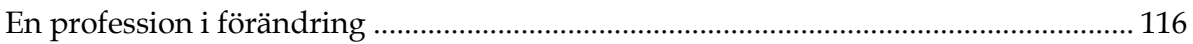




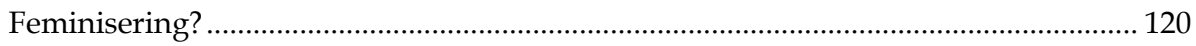

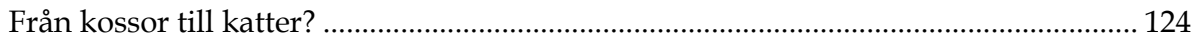

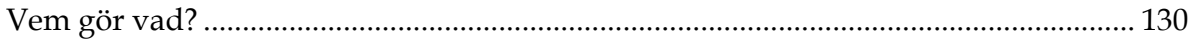

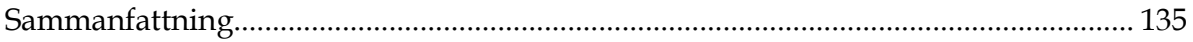

\section{Del 3}

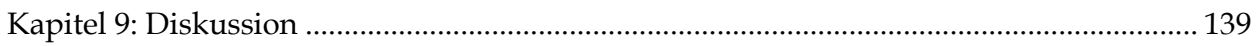

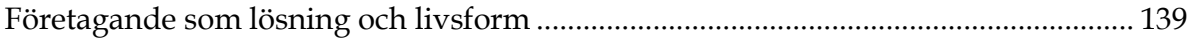

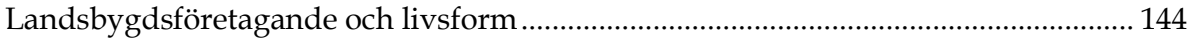

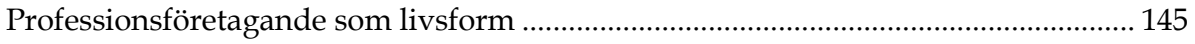

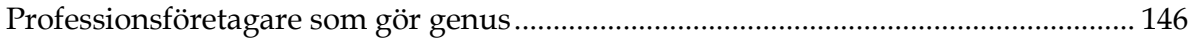

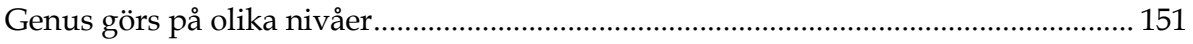

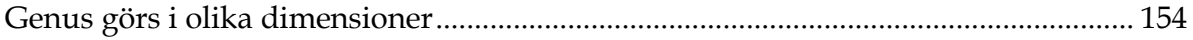

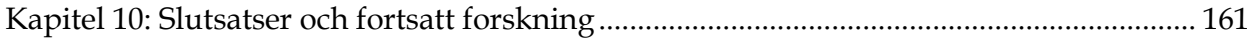

Hur yttrar sig samspelet mellan företagande och profession? ....................................... 161

Hur görs genus i företagande respektive profession? ....................................................... 163

Hur påverkar förändringar inom profession och företagande hur genus görs? .......... 165

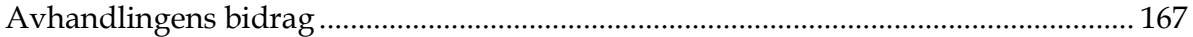

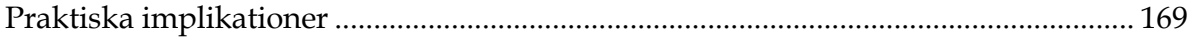

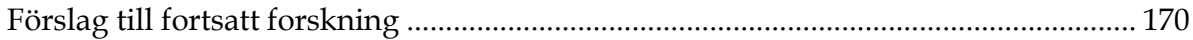

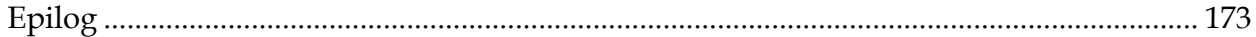

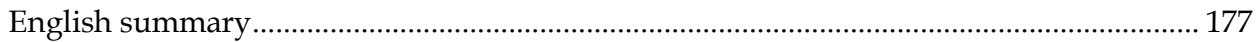

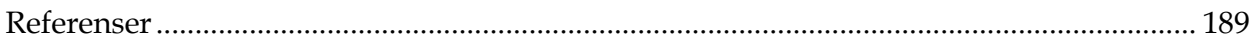


I avhandlingen ingår delar av text från min licentiatavhandling. Nedan följer en sammanställning över var i avhandlingen dessa texter återfinns. Vid respektive textavsnitt finns dessutom en referensnot.

Kapitel 2: sida 14-15, 17-19, 21, 24, 26-29

Kapitel 3: sida 33, 35, 41

Kapitel 4: sida 63-72

Kapitel 5

Bilaga 1

Bilaga 2 


\section{Förteckning över bilagor}

1: Intervjuguide

2: Översikt statliga myndigheter och övriga aktörer

3: Dokumentstudie

4: Litteraturstudie

5: Översikt över intervjupersonerna, samlad matris

\section{Förteckning över tabeller}

2-1: Antal Saco-anslutna medlemmar i Sveriges Veterinärförbund uppdelat på yrkesverksamma och icke-yrkesverksamma

2-2: Antal Saco-anslutna medlemmar i Sveriges Veterinärförbund uppdelat på arbetsmarknadsområde

2-3: Lönekartläggning veterinärer

3-1: Domän, betonad aspekt och mål med företagande. Bearbetad från Lönnbring (2003:137)

4-1: Tidslinje avseende forskningsprocessen

4-2: Översikt intervjustudie

4-3: Reducera och redigera transkriberad text, ett exempel

4-4: Sammanförande av kategorisering

4-5: Identifiering och framskrivning av teman

6-1: Översikt tidsdimensioner

7-1: Översikt företagande

8-1: Översikt professionsutövning

10-1: Sammanfattning av avhandlingens bidrag för respektive forskningsfråga

\section{Förteckning över figurer}

1-1: Skärningspunkten mellan småföretagande, profession och genus

3-1: Typer av kvinnliga företagare. Bearbetad från Goffee och Scase (1985:55)

3-2: Företagande som uttryck för individens position avseende självständighet (beroende - autonomi) och förhandlingsstyrka (överordning - underordning). Med vänligt tillstånd från Sundin och Holmquist (1989:148)

3-3: Strategier för stängning. Översatt från Witz (1992:45), med vänligt tillstånd från UK Book Permissions

4-1: Överlappningar mellan småföretagande, profession och genus

9-1: Att göra genus; dimensioner och nivåer (veterinärer)

10-1: Att göra genus; dimensioner och nivåer 

The road goes ever on and on, down from the door where it began Now far ahead the road has gone, and I must follow if I can.

Pursuing it with eager feet, until it joins some larger way where many paths and errand meet, and whither then? I cannot say 

Del 1 



\section{Prolog}

Sensommaren håller på att övergå i höst och jag styr mot den östgötska landsbygden. Idag ska jag intervjua Eva; en företagare och tillika hästveterinär. Evas beslut att bli veterinär kopplar hon delvis till sin morbror veterinärens svar på den då tolvåriga Evas fråga om det var roligt att vara veterinär. Morbrodern svarade att det var det, men tillade att det inte var något flickor kunde bli. Eva påbörjade veterinärutbildningen i slutet av 1970-talet och tog sin examen 1981. Redan då hon började var en majoritet av de veterinärstuderande kvinnor. Ändock var Evas upplevelse att $i$ synnerhet hästveterinärer var en utvald skara; skickliga, smarta och främst män.

Hennes avsikt var från början inte att bli företagare. Under sina första år som legitimerad veterinär var Eva anställd vid ett djursjukhus. För att kunna utvecklas som veterinär på egna villkor startade hon dock eget redan på 1980-talet. Sedan dess har hon pendlat fram och tillbaka mellan att vara anställd och företagare. Vi pendlar också $i$ intervjun mellan profession och företagande som centrala ämnen $i$ Evas berättelse. Vi landar dock ständigt i professionen. Eva säger:

Jag är inte särskilt road av att driva företag, det är inte den viktigaste grejen för

mig. Jag driver företag för att det är den bästa formen för min verksamhet. 


\section{Kapitel 1}

\section{Kvinnors företagande i en profession stadd i förändring}

$\mathrm{S}$ om framgått av prologen handlar den här avhandlingen om kvinnor som är veterinärer och utövar sitt yrke som egna företagare. Att de är veterinärer innebär att de är verksamma inom en sektor som är stadd i förändring.

Sverige har som många andra länder i världen de senaste decennierna genomgått omvandlingar som syftat till att öka det privata ägandet inom verksamheter som tidigare utförts av det offentliga (Regeringens proposition, 1990/91). Ibland har företagandet också ökat (Tillväxtverket, 2015). De politiska ambitionerna har varit att öka just kvinnors företagande (Hirdman, 2014; Olofsson, 2010). Det långsiktiga utfallet av omvandlingarna är på den punkten ännu oklara, men på kortare sikt visar kvantitativ forskning att mäns företagande ökar mer än kvinnors (Sköld \& Tillmar, 2015). Kvalitativa och kvantitativa studier av omvandlingarna förstärker slutsatsen att genussystemet reproduceras i företagandet, internationellt (Thomas \& Davies, 2002) såväl som i en svensk kontext (Sköld, 2015; Sundin, 2011; Sundin \& Tillmar, 2010a).

Omvandlingarna påverkar samtidigt i hög grad professioner som exempelvis läkare, tandläkare och lärare genom en minskning av offentlig verksamhet och ökning av verksamhet i privat regi (Svensson, 2003). Professioner såsom läkare, revisorer och lärare genomgår även förändringar i form av en ökad andel kvinnor, både i Sverige (Florin, 1987; Jonnergård \& Stafsudd, 2009; Nordgren, 2000) och internationellt (Crompton \& Lyonette, 2011; San Román \& Cortina, 2006). Av tidigare forskning vet vi att utbildning har betydelse för kvinnors småföretagande bl.a. genom att ge trygghet och legitimitet i exempelvis kontakten med myndigheter (jmf Holmquist \& Sundin, 2002). Samtidigt visar studier av flera så kallade statusprofessioner, såsom 
läkare och jurister, på en könsmärkt uppdelning inom professionen (Einarsdóttir, 1997; Lindgren, 2008).

För att utröna hur och varför småföretagandet utvecklas som det gör över tid, och hur det påverkar och påverkas av genussystemet, behövs mer kunskap om kvinnors företagande inom professioner som är stadda i förändring. Den profession där andelen kvinnor bland de yrkesverksamma ökat mest dramatiskt i Sverige, men även internationellt, är veterinärprofession (Irvine \& Vermilya, 2010; Saco, 2014), som därför utgör studiens empiriska fall.

Nedan diskuterar jag först kort forskningen om kvinnors företagande och därefter forskningen om professioner i förändring. Därefter presenteras syfte och forskningsfrågor.

\section{Kvinnors företagande}

Kvinnors företagande har i forskningssammanhang ägnats allt större uppmärksamhet de senaste decennierna (Achtenhagen \& Tillmar, 2013). Internationellt har bland andra Diana-gruppen (Gatewood, Brush, Carter, Greene, \& Hart, 2009) spelat en viktig roll (Holmquist \& Carter, 2009). I Sverige har forskningen om kvinnors företagande, i internationell jämförelse, haft en stark position med start i en pionjärstudie i slutet av 80-talet (Sundin \& Holmquist, 1989). Men även om forskningen om kvinnors företagande gått framåt de senaste 25 åren utgör den fortfarande en liten del av forskningen om småföretagande och entreprenörskap (Sundin \& Holmquist, 2015). Forskningen har i linje med rekommendationer från bl.a. Ahl (2006) samt Hughes et al (2012) rört sig mot alltmer konstruktivistiska ansatser, såsom "doing gender" (West \& Zimmerman, 1987).

"Doing gender" är ett samlingsnamn för en teoretisk utgångspunkt där genus ses som något som konstrueras socialt, på svenska ofta uttryckt som att genus "görs"1. Med begreppet poängteras vikten av att se genus som något som skapas ständigt och rutinmässigt i vår vardag, i interaktioner mellan människor samt i relation till en viss kontext (West \& Zimmerman, 1987).

Genussystemet är ett sätt att beskriva och belysa maktrelationer mellan könen på en strukturell nivå (SOU, 1990:44). Principerna segregering och hierarkisering utgör grunden för genussystemet (Hirdman, 1988). Segregering yttrar sig i särhållning av kvinnor och män, genom arbetsdelning eller i starka dikotomier kring vad som är

\footnotetext{
${ }^{1}$ Då hur genus "görs" är ett återkommande begrepp i den här avhandlingen väljer jag härefter att skriva ut det utan citattecken. "Doing gender", såsom ett engelskt begrepp, skrivs dock inom citattecken.
} 
manligt respektive kvinnligt. Hierarkisering, i form av sortering och värdering, tar utgångspunkt $\mathrm{i}$ mannen som norm och kvinnan som avvikande. Tidigare forskning har visat att företagande är manligt könsmärkt (Ahl, 2006; Sundin, 2002). Andra studier visar att profession är manligt könsmärkt på liknande sätt (Davies, 1996; Johansson, 1997). Detta torde innebära att kvinnor som företagare i professioner är avvikande i dubbel bemärkelse.

En teoretisk ansats där "doing gender" kombineras med genussystemets principer av hierarkisering och segregering är ett fruktbart sätt att studera genus i och med att såväl struktur som aktör synliggörs (jmf Kvande, 2003). Genussystemet kritiseras för att inte ta tillräcklig hänsyn till aktörer (jmf Wetterberg, 1992) och "doing gender" för att inte ta tillräcklig hänsyn till strukturer (jmf Collins et al., 1995). För att förstå hur företagare i en profession gör genus och påverkas av genussystemet behöver perspektiven kombineras.

Forskningen om kvinnors företagande präglas av en mångfald av perspektiv och har genom åren ändrat inriktning "från att vara konkret kopplad till empirin (genom stora datainsamlingar och ingående fallstudier) har den gått till att bli mer internt akademiskt fokuserad" (Sundin \& Holmquist, 2015:137). Postmoderna influenser har även tagit sig uttryck i forskningen med inriktning mot diskurser i bl.a. media och forskning gällande kvinnors företagande (jmf Berglund, 2007; Hamilton, 2013; Hjorth \& Steyaert, 2004; Pettersson, 2002). Sådan forskning är viktig för att förstå mediabilden och konstruktionen av genus på makronivå. Jag menar att det är av vikt att forskningen om kvinnors företagande även fortsättningsvis också innehåller studier som ligger nära företagarens vardag. I analogi till att Barley och Kunda (2001) förespråkade en återgång till att studera det konkreta arbetets organisering, vill jag bidra till forskningen om kvinnors företagande genom en vardagsnära studie av hur företagandet upplevs och beskrivs av företagarna själva.

För att förstå förutsättningarna för kvinnors företagande är det vidare viktigt att ta hänsyn till det sammanhang $\mathrm{i}$ vilket företagandet utförs (jmf Achtenhagen \& Tillmar, 2013; Ahl, 2006; de Bruin, Brush, \& Welter, 2006; Hughes et al., 2012). Detta då all ekonomisk aktivitet, liksom varje individ, är inbäddad i och därmed del i, sin omgivning (Granovetter, 1985). Denna inbäddning kan vara både en tillgång och en belastning och avser sammanhang såsom ex. anställning, livsval, karriär, välbefinnande, makroekonomiska förhållanden och plats (Bögenhold \& Fachinger, 2013; Sundin \& Holmquist, 1989; Welter, 2011; Zahra, 2007). I den här avhandlingen är det professionskontexten som står i fokus. För att förstå den behöver vi ta hjälp av teoribildning och tidigare studier om profession. 


\section{Professioner i förändring}

Profession avser en yrkesmässig organisering av arbete (Molander \& Terum, 2008) vars medlemmar har monopol på en viss kunskap och traditionellt har haft en viss autonomi i sitt arbete (Freidson, 2001). Mintzberg (1980) betraktade "professionsbyråkratier" som en särskild typ av platta organisationer där koordinering sker genom gemensam standardiserad kunskap. I utvecklingen av de europeiska välfärdsstaterna blev många professionella anställda och integrerade i stora offentliga organisationer (Sehested, 2002). Förutsättningarna för många professioner ändras dock i flera dimensioner, i och med samhällsomvandlingar som exempelvis New Public Management (Brock, 2006; Jonnergård, Funck, \& Wolmesjö, 2008). I debatten uppmärksammas framför allt vård och omsorg men även jurister och revisorer påverkas av dessa förändringar (Svensson, 2003). Marknader för professionsorganisationer avregleras, konkurrensen ökar både inom och mellan professioner, det är en ökad fokus på finansiella begränsningar, kunderna blir kunnigare och mer krävande och teknologiska innovationer öppnar i vissa fall upp för inträde av nya leverantörer (Brock, 2006). Till dessa förändringar kan även läggas globalisering med en ökande internationalisering av professionella tjänster såsom juridik och revision till förmån för multinationella klienter (Brock, 2006).

Den positiva status som medlemskapet i en profession ger möjliggör etablering av företag, bland annat då det minskar inträdesbarriärer och inte minst därför att affärsidén delvis är given (Gustavsson \& Rönnqvist, 2004). Exempel på professioner med störst andel företagare är jurister, arkitekter, tandläkare och veterinärer (Svensson, 2003). För andra professioner såsom socionomer har företagande på senare år förts fram som en professionaliseringsstrategi (Dellgran \& Höjer, 2005). Med utgångspunkt i Sacos samtliga medlemsförbund visar statistiken på en viss ökning av företagandet ${ }^{2}$. Kvinnors andel av detta företagande har ökat. Statistiken visar att den profession där företagande har ökat mest under 2000-talet är veterinärprofessionen (Saco, 2004, 2014).

Professionerna förändras även $i$ andra dimensioner. Av särskilt intresse för föreliggande studie om kvinnors företagande är den numerära feminiseringen ${ }^{3}$ som skett inom många professioner. Allt eftersom kvinnor fått tillgång till

\footnotetext{
${ }^{2}$ Statistik visar att antalet företagare har svängt genom åren och varierar mellan olika professioner. Statistiken kommer från Sveriges akademikers centralorganisation (Saco) vars medlemsförbund inkluderar flera etablerade professioner såsom jurister, lärare, arkitekter, läkare, tandläkare och veterinärer.

${ }^{3}$ Begreppet Feminisering är omdebatterat och många gånger otydligt (se vidare diskussion om detta i kapitel 3). I denna studie väljer jag att använda mig av benämningen numerär feminisering fortsättningsvis för att tydliggöra att förändringen jag hänvisar till är den i antal/andel män och kvinnor snarare än i termer av att professionen präglas av feminina konnotationer.
} 
universitetsutbildning har andelen kvinnor ökat inom de tidigare manligt dominerade professionerna (Högskoleverket, 2005; jmf Slater \& Slater, 2000).

Sedan 1990-talet har studier av genusdimensionen alltmer uppmärksammats även inom professionsforskningen. Inslag av genus i professionsforskning i Sverige återfinns huvudsakligen i studier av läkarprofessionen. Exempelvis har sambandet mellan en numerär feminisering och en eventuell avprofessionalisering analyserats av Nordgren (2000). Konsekvenserna av feminiseringen inom läkarprofessionen har analyserats av Einarsdottir (1997) som bland annat diskuterar intern segregering genom olika specialiseringar. En liknande frågeställning, men inom revisorsprofessionen, diskuteras av Jonnergård och Stafsudd (2009). Forskarna visar bland annat att både kvinnor och män tillskrivs genusstereotypa egenskaper i revisorsprofessionen. Då professioner styrs genom gemensam kunskap, förståelse och normer blir dessa centrala för den professionella verksamheten (Jonnergård \& Stafsudd, 2009).

Flera av de klassiska professionerna präglas av en manlig könsmärkning (jmf Bolton \& Muzio, 2008) och professionerna har traditionellt sett och generellt uttryckt varit mansdominerade och historiskt uppbyggda enligt så kallade manliga normer (Davies, 1996; Lindgren, 2000). Organisationsforskningen har dock visat att en organisation som domineras av kvinnor inte behöver präglas av korresponderande kvinnliga konnotationer och normer (Acker, 1990; Britton, 2000). Detta gäller även för professioner och i en studie av veterinärprofessionen visar Irvine och Vermilya (2010) att professionen, med en majoritet kvinnor, fortfarande bär med sig drag av maskulinitet vad gäller tillskrivna egenskaper och normer. En åtskillnad av män och kvinnor bibehålls därmed inom professioner i form av intern segregering, ibland som en avgränsningsstrategi baserad på olika specialiseringars status inom professionen (jmf Einarsdottir, 1999; Witz, 1992). Professioners manliga könsmärkning förefaller därmed seglivad (Bolton \& Muzio, 2008; Bottero, 1992).

Flera professioner förändras alltså både i termer av i vilken organisatorisk form och sektor de utövas, och i termer av en numerär feminisering. Hur detta påverkar de normer som är så centrala för professionerna är ännu oklart eftersom förändringarna är pågående.

\section{I skärningspunkten mellan småföretagande, profession och genus}

Företagare som Eva är exempel på företagare som förhåller sig såväl till sin situation som småföretagare som till profession och till genus. Bland det fåtal studier som finns från och belyser denna skärningspunkt kan nämnas Marlow och Carter (2004), vars 
studie gjordes i Storbritannien och av revisorsprofessionen. Forskarna menar att det underläge som det innebär att vara kvinna och företagare består även i kontexten av en profession. I en svensk studie av företagarpar bestående av advokater och ICAhandlare, menar Javefors Grauers (2002) emellertid att medlemskap i en profession är till de företagande kvinnornas fördel i jämförelse med att inte vara det. Den komplexa interaktionen mellan genus, profession och företagande uppmärksammas även av Lindgren (2000) samt Kovalainen \& Österberg-Högstedt (2013). Båda studier lägger dock fokus på identitet och identitetskonstruktion på individnivå.

Ovan har jag argumenterat för att det inom fältet kvinnors företagande fortfarande behövs mer vardagsnära studier, som tar hänsyn till kontexten. Jag har också argumenterat för att vi i de pågående samhällsomvandlingarna behöver mer kunskap om företagande i professioner samt hur professioner, och dess företagande, påverkas av numerär feminisering. Den här studien bidrar med sådan kunskap genom att fokusera på kvinnors företagande i en profession. För att förstå företagande såsom Evas kombinerar jag teoribildning från forskningsfälten småföretagande, profession och genus. Det är i skärningspunkten mellan de tre teoretiska fälten som avhandlingen ger sitt huvudsakliga bidrag. Figur 1-1 illustrerar de tre forskningsfälten, och skärningspunkten där de möts.

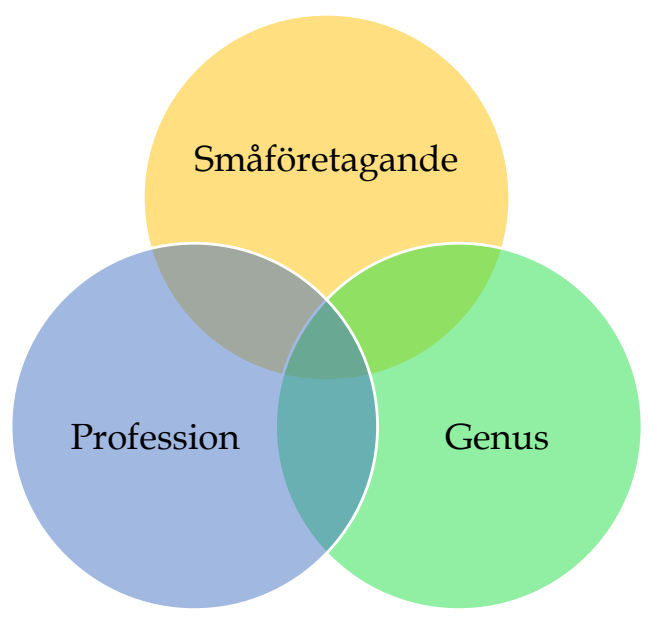

Figur 1-1: Skärningspunkten mellan småföretagande, profession och genus 


\section{Syfte}

Syftet med denna studie är att beskriva och analysera kvinnors företagande inom en profession stadd i förändring utifrån vad som sker i skärningspunkten mellan småföretagande, profession och genus. Specifikt analyseras hur genus görs bland företagare som är kvinnor och medlemmar av en profession stadd i förändring.

$>$ Hur yttrar sig samspelet mellan företagande och profession?

$>$ Hur görs genus i företagande respektive profession?

Hur påverkar förändringar inom profession och företagande hur genus görs?

\section{Fallet veterinärprofessionen}

I denna studie utgör veterinärprofessionen det empiriska fallet. Veterinärer är ett intressant fall för att studera kvinnors företagande $i$ en profession stadd i förändring av flera orsaker.

Den första orsaken är att veterinärprofessionen är ett tydligt exempel på en statusprofession som numerärt feminiserats. Professionens numerära feminisering är ett internationellt fenomen (Henry \& Treanor, 2012b; Lofstedt, 2003; Maines, 2007) men är särskilt dramatisk i Sverige (Östensson, 2010). År 2014 var 77 \% av landets verksamma veterinärer kvinnor (Saco, 2014) och andelen kvinnor antagna till veterinärutbildningen var 87 \% (Statistiska Centralbyrån, 2014).

Den andra orsaken är att veterinärprofessionen även präglas av ett flertal förändringar gällande såväl i djurhållning och därmed även i vilka djur som utgör veterinärernas primära arbetsområde samt ett ökat företagande, både i fråga om antalet företagare och företagens storlek (Appelgren, Jämte, \& Östensson, 2010; SOU, 2007:24). År 1995 genomfördes en omorganisation av distriktsveterinärorganisationen, följden blev ett omfattande avhopp av distriktsveterinärer som istället valde att bli företagare (SOU, 2007:24).

\section{Disposition}

Avhandlingen är indelad i tre delar där den första delen introducerar studien, veterinärprofessionen som kontext samt presenterar den teoretiska referensramen. Här presenteras även metoden. Resultatet presenteras i del två och diskuteras sedan i del tre, där även slutsatser och fortsatt forskning ingår. 
Del 1: I föreliggande kapitel (1) har jag introducerat studiens ämne vilket har utmynnat i ett syfte med vidhängande frågeställningar. Kapitel 2 ger en bakgrund till veterinärprofessionen och är resultatet av en dokumentstudie som genomförts inom ramen för denna studie. Den teoretiska referensramen introduceras i kapitel 3. I kapitel 4 presenteras de vetenskapsteoretiska och metodologiska ställningstaganden som utgör ramen för denna studie. Här ges även en ingående redogörelse för, och diskussion kring, det praktiska tillvägagångssättet vid genomförandet av studien.

Del 2: Denna del av studien består av fyra kapitel. I det första kapitlet (5) presenteras intervjupersonerna i form av porträtt. Det tematiserade resultatet från intervjuerna presenteras i kapitel 6-8. I kapitel 6 läggs fokus på livet som veterinär och företagare, I kapitel 7 på livet som företagare och kvinna. Slutligen är det livet som veterinär och kvinna som står i centrum i kapitel 8.

Del 3: Därpå följer en diskussion av resultatet i förhållande till teori (kapitel 9) och till sist, i kapitel 10, presenteras studiens slutsatser tillsammans med ett avsnitt om fortsatt forskning. 


\title{
Kapitel 2
}

\section{Veterinärprofessionen i Sverige}

\begin{abstract}
A vsikten med detta kapitel är att beskriva bakgrunden till veterinärprofessionen i Sverige idag, för att på så sätt introducera det sammanhang som studiens intervjupersoner verkar inom. Kapitlet inleds med ett historiskt ramverk som sätter in veterinärprofessionen i tid och rum. Här inkluderas aspekter av strukturella omvandlingar med fokus på övergången från industri- till tjänstesamhälle samt jordbrukets och djurhållningens utveckling. Därefter redogörs för veterinärprofessionens historik, organisering och numerära feminisering.
\end{abstract}

\section{Samhällsomvandlingar}

Strukturella omvandlingar har de senaste 100 åren förändrat det svenska samhället. Vi har gått från en omvandling av jordbrukssamhället till olika grader av industrialisering och till industrisamhällets höjdpunkt åren 1930-1975. De senaste decenniernas utveckling kan ses som slutet på industrins dominans och som en övergång till ett tjänstesamhälle (Schöön, 2014). Antalet sysselsatta i den traditionella industrin har minskat allteftersom industriarbete automatiserats, rationaliserats och omlokaliserats till nya regioner och länder (Ekstedt \& Sundin, 2006; Johannisson \& Lindmark, 1996a). Arbetskraften har istället kommit att riktas mot tjänsteverksamhet, ett tjänstesamhälle har formats (Johannisson \& Lindmark, 1996a). Samhället har gått från jordbruk, fiske och grovarbete via produktion och tillverkning till en ekonomi som idag till stor del baseras på service och tjänster (Bögenhold, 2004; Ekstedt \& Sundin, 2006). I samhällen där mer produceras snabbare, i kombination med en ständig minskning av arbetsinsatser, är det främst områden som transport, handel, konsumtion och fritid som ökar. I spåren av ett tjänstesamhälle följer även en ökning av egenföretagande där företagen till storlek blir allt mindre (Bögenhold, 2004). Som 
vi ska se nedan har den etappvisa omvandlingen även påverkat veterinärprofessionen och dess arbetsfokus.

I början av 1970-talet var Sverige fortfarande det högst industrialiserade landet i Norden. Därefter och fram till år 2010 kom emellertid sysselsättningen att kraftigt förändras. Jordbruk, industri och byggnadsverksamhet minskade sin andel av den totala sysselsättningen från 45 till 30 procent. Samtidigt ökade tjänstesektorerna och år 1995 stod de för 70 procent av sysselsättningen. Fram till år 1990 drevs expansionen av tjänster främst av den offentliga sektorn men perioden 1985-1995 blev en genombrottsperiod för den privata tjänstesektorn. När de offentliga finanserna stramades åt efter krisåren i början av 1990-talet kom de privata tjänsterna alltmer att stå för tillväxten i sysselsättningen (Schöön, 2014).

Omvandlingen av den offentliga sektorn de senaste decennierna sätts ofta i direkt relation till fenomenet New Public Management (NPM), vilket är samlingsnamnet för trender som privatisering och nedskärningar i offentlig sektor (Hasselbladh \& Bejerot, 2008; Hood, 1995). Denna omvandling uppstod under 1980-talet och är fortgående i Sverige och ett antal OECD-länder ${ }^{4}$ (Hood, 1995; Montin, 2007; Tillmar, 2009). Tidigare ledord inom den offentliga sektorn som tillgänglighet och likställdhet byts i och med omvandlingen mot valfrihet och vinstintresse (Lundström \& Sundin, 2008; Montin, 2007). I den svenska regeringspropositionen från år 1990 drevs frågor om den offentliga sektorns utveckling utifrån argument att sektorn expanderat alltför snabbt. En ökad konkurrens poängterades som en möjlig effekt av att utsätta den offentliga sektorn för marknadsmässiga förutsättningar (Regeringens proposition, 1990/91).

\section{J ordbrukets utveckling}

Jordbruket i Sverige har som en del i ovan beskrivna strukturella omvandling genomgått kraftiga förändringar de senaste 100 åren. Då veterinärprofessionen traditionellt sett varit tätt knuten till jordbrukets djur har förändringarna även haft implikationer för professionens arbete. Främst perioden efter andra världskriget fram till mitten av 1970-talet kan ses som särskilt omvälvande, cirka 750000 människor lämnade då jordbruket (Flygare \& Isacson, 2003; Schöön, 2014). Sedan 1940-talet har andelen sysselsatta i jordbruk med binäringar minskat från 25 till knappt 2 procent (Isacson, 2008). Sveriges jordbruk omvandlades under denna period från en basnäring som i första hand byggde på djurs och människors muskelkraft, till en högteknologisk näring som är hårt specialiserad med ett begränsat antal sysselsatta (Flygare \& Isacson, 2003).

\footnotetext{
${ }^{4}$ Organisation for Economic Co-operation and Development.
} 
Jordbrukets utveckling och omvandling påverkades inte minst av mekanisering och teknisk utveckling där hästdragna slåttermaskiner ersatte liar och räfsor i slutet av 1800-talet, och där traktorer stegvis kom att ersätta arbetshästar innan och efter andra världskriget. Parallellt kom även elbelysning till byarna och gårdarna. På detta sätt blev livet på landet alltmer stadslikt (Isacson, 2008).

Så länge jordbruk bedrivits har det varit en angelägenhet för båda könen. Ändå tenderar föreställningar om jordbruk, och i förlängningen landsbygden, ha en manlig prägel. Kvinnor har dock genom alla tider i högsta grad deltagit i de flesta tunga fysiska jordbruksarbeten - kvinnans fysik sågs sällan som ett hinder i det dagliga arbetet (Flygare, 1999). Det var inte ovanligt för kvinnor att överskrida könsgränserna och bredda sina ansvarsområden vid behov, exempelvis i tider då männen drog ut $\mathrm{i}$ krig eller tillbringade långa perioder till sjöss eller i skogsarbete. Däremot ansågs det under en mans värdighet att utföra typiskt kvinnliga sysslor. På detta sätt kan den könbestämda arbetsdelningen $\mathrm{i}$ jordbruket beskrivas som flexibel, men där kvinnorna stått för flexibiliteten (Flygare \& Isacson, 2003). Landsbygdens förändring och dess inverkan på könsmönster och jämställdhet behöver inte vara entydig. Det finns en risk att traditionella mönster består då invanda mönster är trygga men det kan även innebära en möjlighet att hitta nya roller i tider då man inte har råd att vara könsbunden. Landsbygdsmiljöer kan vara begränsande för både män och kvinnor (Stenbacka, 2008).

\section{Djurslagens könsmärkning}

Under flera hundra år ansågs det som kvinnogöra att mjölka och ta hand om gårdens kor (Sommestad, 1992). För en man var sådana sysslor otänkbara att utföra. Hästarnas skötsel var däremot husbondens ansvarsområde. Andra män på gården, som drängen, äldsta sonen eller farfar, kunde involveras i det dagliga arbetet med att fodra, rykta och mocka. Ladugården där korna huserade var dock kvinnornas domän, även när det gällde att mocka (Flygare, 1999).

I slutet av 1800-talet inleddes dock en könsmärkningsförändring av det tidigare så renodlat kvinnliga arbetsområdet - mejeriproduktion - och män började ersätta kvinnorna i detta yrke. Resultatet blev att kvinnornas hantverkskunnande ersattes av maskinteknologi (Schöön, 2014; Sommestad, 1992). Sommestad (1992) menar att anledningarna till att män kunde tränga undan kvinnorna står att finna i samspelet mellan industriell utvecklingen, kulturella och politiska faktorer. Arbete med häst, som tidigare varit traditionellt manligt könsmärkt utvecklades i motsatt riktning (Flygare, 1999; Forsberg, 2012). Så länge hästarna användes i jordbruket var de prestigefyllda djur som ägnades stor omsorg och var manligt könsmärkta. Hästen kom dock i och med mekaniseringen av jordbruket att ersättas av traktorn och arbetet med hästen började istället allt mer ses som kvinnligt (Flygare, 1999). I och med denna 
förändrade könsmärkning ökade mjölkningsarbetets status medan hästen förlorade i status (Javefors Grauers, 2003).

Synen på hästen har under de senaste 50 åren därmed förändrats från ett redskap för transport och jordbruk till att ses som en redskap för att skapa upplevelser inom sport, fritid och rekreation (Forsberg, 2012). Förändringen har även yttrat sig i en förändrad könsmärkning. På mindre än 50 år har hästen gått ifrån att vara mannens till kvinnans område. Förändringen kan inte minst kopplas till hästens minskade betydelse i armén och jordbruket. Ridhästen, med betydelse för folkhälsan snarare än något annat, blev inte legitim för mannen att investera i som fritidsverksamhet. Mannens arbetshäst blev därmed kvinnans vårdobjekt (Forsberg, 2012). Stallet blev en plats där ungdomar, framför allt flickor, fann en plats att utöva en livsstil och på 1970-talet kom dessa hästar att i veterinärmun benämnas som "tjejmopeder" (Hammarberg, 2010).

\section{Från lantbruksdjur till sällskapsdjur}

Djurhållningen ${ }^{5}$ i Sverige har parallellt med jordbruket genomgått stora förändringar. De flesta lantbruksdjur har minskat betydligt i antal under de senaste 25 åren. Antalet grisar i Sverige minskade med drygt 33 procent, antalet nötkreatur med cirka 15 procent och mjölkkor med nästan 40 procent mellan åren 1980-2005. Det har även skett en förändring $\mathrm{i}$ antalet kor per besättning ${ }^{6}$ som har ökat samtidigt som beståndet i landet i stort har minskat. En genomsnittlig kobesättning bestod år 1980 av cirka 15 kor för att 25 år senare uppgå till 46. I intervjuer med veterinärer i samband med Veterinärutredningen 2007 framhölls det som en positiv utveckling. Det sågs då som fördelaktigt att spendera en hel dag vid en stor besättning snarare än att åka runt till flera mindre besättningar, ofta med stora avstånd emellan (SOU, 2007:24).

Enligt statistik från Jordbruksverket (2012) var antalet hästar i Sverige 362700 år 2010. Detta kan jämföras med hästens storhetstid under 1920-talet då antalet hästar i Sverige uppgick till drygt 700000 (SOU, 2007:24). Mellan åren 2004-2010 ökade antalet hästar med 10-20 procent (Jordbruksverket, 2012). Hästantalet är tydligt beroende av befolkningens storlek och i länen med störst befolkningsmängd återfinns därmed högst antal hästar (SOU, 2007:24).

Hunden och katten har under 1900-talets andra hälft uppgraderats från att bedömas efter sina förmågor som jägare eller jaktassistent (hunden) och musjägare (katten) till att ses som familjemedlemmar (Hammarberg, 2010). Antalet hundar och katter i Sverige uppgick år 2006 till 729000 respektive 1256 000, vilket gör katten till det

\footnotetext{
${ }^{5}$ Innehållet under denna rubrik är delvis text från min licentiatavhandling (Appelkvist, 2013:25-27).

${ }^{6}$ Djurbestånd vid exempelvis en gård.
} 
vanligaste sällskapsdjuret i Sverige. Båda djurslagens antal förväntas fortsätta att öka (Manimalis, 2009).

Även om människans kontakt med lantbruksdjuren minskat under de senaste 50 åren finns fortfarande ett intresse och en vilja att omge sig med djur. Djurslagen och synen på dem har dock delvis förändrats (Hammarberg, 2010). För veterinären har det inneburit ett skifte i fokus - från lantbruksdjur (kor, får grisar etc.) till sällskapsdjur (hund, katt, häst etc.).

Samtidigt med minskningen av lantbruksdjur och ökningen av sällskapsdjur har efterfrågan på djursjukvård för sällskapsdjur ökat. Även antalet vårdinsatser per djur har ökat. Trenden i Sverige och internationellt är att sällskapsdjuren ses mer som familjemedlemmar än tidigare. Djurägarna har därmed blivit alltmer benägna att söka vård för sina sjuka djur. En ökning av antalet sällskapsdjur som är försäkrade är ytterligare en förklaring till att antalet vårdinsatser ökat. Med en sjukvårdsförsäkring betalar djurägaren en summa motsvarande självrisken till vårdgivaren medan försäkringsbolaget står för resterande kostnad. Försäkringarna har därmed en stor betydelse för huruvida djuren får vård eller avlivas (SOU, 2007:24). Omkring 80 procent av alla hundar är numera försäkrade och antalet ökar stadigt (Agria Djurförsäkring, 2012). Försäkringsgraden för Sveriges vanligaste sällskapsdjur katten ökar också. Under de senaste 6 åren har den ökat från 27 till 36 procent. För yngre katter är försäkringsgraden nästa 40 procent, en försäkringsgrad som är unik i världen, särskilt för katt. I Norge och Danmark är endast 2 procent av katterna försäkrade (Agria Djurförsäkring, 2013).

\section{Veterinärprofessionen - historik}

Ursprunget $^{7}$ till den svenska veterinärprofessionen uppstod i kölvattnet av de smittsamma farsoter bland lantbruksdjur som drabbade Europa under 1700-talet (Hallgren, 1962). Dessa farsoter utsatte såväl ekonomin som livsmedelsförsörjningen i de europeiska länderna för stora påfrestningar och satte ljuset på behovet av en yrkeskår som kunde hantera liknande problem i framtiden. Enligt vissa beräkningar dog cirka 200 miljoner nötkreatur i boskapspest i Europa under 1700-talet (SOU, 2007:24).

Den första regelrätta veterinärutbildningen i världen startades i Frankrike 1762 och året efter beslutade den svenska staten att sända tre stipendiater för att ta del av utbildningen (Jönsson, 2010). En av stipendiaterna, Peter Hernqvist, anses allmänt vara den svenska veterinärprofessionens grundare. Hernqvist fick, efter avklarad

\footnotetext{
${ }^{7}$ Innehållet under denna rubrik förutom det sista stycket är helt eller delvis text från min licentiatavhandling (Appelkvist, 2013:13-15).
} 
utbildning, i uppdrag av Kung Gustaf III att starta veterinärinrättningen i Skara år 1775. Detta skedde i samband med att Hernqvist framgångsrikt behandlat ett utbrott av en dödligt smittsam sjukdom bland hästar vid två av statens stuterier. Under sin livstid utbildade Hernqvist cirka 150 veterinärer (Hallgren, 1962).

Flera utbildade veterinärer sökte sig under 1800-talet till krigsmakten (Hallgren, 1962). Deras vanliga beteckning blev hovslagare. För att dryga ut den ringa lön hovslagarna erhöll från staten bedrev de privat även viss praktik på lantbrukets djur. Några hovslagare övergick snart till att bli veterinärer och fick anställning av socknar samt på större gårdar och bruk. Till en början hade de utbildade veterinärerna svårt att klara konkurrensen från det som klassades som okunskap, kvacksalveri och "kloka gummor". Att kombinera arbetet som veterinär med att exempelvis vara klockare i ett pastorat var ett vanligt sätt för den tidens veterinärer att trygga sina inkomster. Detta var en medveten strategi av den svenska veterinärprofessionens grundare som vid sidan av veterinärundervisningen även utbildade sina elever till klockare. Tanken var att försäkra sig om att eleverna efter utbildningens slutförande skulle ha möjlighet till en fast inkomst, tjänstebostad och en given roll i samhället (Hallgren, 1962).

Hushållningssällskapen bidrog i stor utsträckning till utbyggnaden av en organiserad veterinärverksamhet (SOU, 2007:24) och uppkom under 1700-talet med målsättning att intressera bönder för nya och bättre odlingsmetoder samt att främja djurskötseln ${ }^{8}$ (Nationalencyklopedin, 2012). De veterinärdistrikt som bildades under 1800-talets första hälft avlönades delvis av hushållningssällskapen, landstingen och kommunerna (SOU, 2007:24).

År 1830 ålades varje län i Sverige att anställa minst en veterinär för att hjälpa provinsialläkarna med bekämpningen av smittsamma djursjukdomar (SOU, 2007:24). Syftet var att etablera en rikstäckande veterinärservice. I och med detta uppkom så småningom Länsveterinärkåren. Under 1800-talets senare hälft bearbetades frågan om statliga bidrag till veterinärer vid flera tillfällen. Först efter sekelskiftet infördes dock statsbidrag till veterinärverksamhet. Innan dess, 1877, etablerades de första distriktsveterinärerna med tjänstgöringsskyldighet och tjänsteårsbeskrivning.

1900-talet var på många sätt ett omvälvande århundrade för veterinärprofessionen. Inte minst med anledning av jordbrukets utveckling. Medan den första halvan gick i konsolideringens tecken förde den andra halvan med sig uppluckring och omorganisationer. För att få ett fastare grepp om distriktsveterinärverksamheten förstatligades den år 1934. Föresatsen från statens sida var att underlätta en likformig

8 Till finansiering fick hushållningssällskapen under lång tid statligt stöd för sin rådgivnings- och serviceverksamhet till lantbruket. Detta statsstöd drogs dock in år 1967 och verksamheten togs istället över av lantbruksnämnderna. Sedan dess har sällskapen verkat på egen hand och beskrivs som en länsvis organiserad sammanslutning som befinner sig i gränslandet mellan privat och offentlig sektor (Nationalencyklopedin, 2012). 
drift i hela landet. Detta bidrog i mycket stor utsträckning till den tradition och standard vi har i Sverige vad gäller smittskydd, sjukdomsbekämpande och djurskydd. Sedan år 1934 har en riks- och dygnsomfattande veterinärservice kunnat erbjudas till en bestämd taxa (SOU, 2007:24).

Även veterinärprofessionen har varit föremål för diskussioner om privatisering och nedskärningar i enlighet med New Public Management. I regeringens proposition (1990/91) konstaterades, som angivits ovan, att den offentliga sektorn expanderat i snabb takt. Något som skett genom ökade skatteintäkter. Samtidigt som det fastslogs att sjukvård, skola och barnomsorg även fortsatt skulle vara tillgängligt för alla på ett likvärdigt sätt, påpekades att utgiftsexpansionen måste dämpas. Det konstaterades att förändringar måste ske genom såväl omprioriteringar som effektiviseringar. Ett av de områden som föreslogs väl lämpat för detta var veterinärprofessionen. Besparingar föreslogs bland annat inom statens veterinärmedicinska anstalt samt distriktsveterinärorganisationen. Någon privatisering blev dock inte aktuell. Huvudmotiven till ett fortsatt statligt huvudmannaskap var att i hela landet garantera djurskydd, smittskydd, officiella uppdrag samt att prioritera lantbruksdjurens behov av veterinära tjänster.

\section{Organisering}

Den svenska veterinärprofessionen beskrivs i Veterinärutredningen (SOU, 2007:24) som splittrad och präglad av en heterogen marknad med oklara roller och ansvarsgränser - både vad gäller den kommersiella marknaden och statens uppgifter med samordning, uppföljning, officiella kontroller och tillsyn. Bland annat fastställs i utredningen att ett oklart uppdrag till de statliga distriktsveterinärerna gör att de konkurrerar på djursjukvårdsmarknaden utanför vad som rimligtvis bör vara det statliga ansvarets gränser. Statliga och privata veterinärer har under långt tid i hög grad utfört samma arbete och fyllt samma funktion, sida vid sida. I och med förändringarna i antalet lantbruksdjur i landet har efterfrågan på sådan vård minskat medan efterfrågan på djursjukvård kraftigt ökat. Situationen har lett till att det uppstått motsättningar mellan statliga och privata aktörer på marknaden. Något som har skapat svårigheter att samarbeta. En effekt som anges i utredningen är att många företagare försöker motverka att statliga veterinärstationer etableras i deras område (SOU, 2007:24).

Även ${ }^{9}$ företagandet i veterinärprofessionen kan beskrivas som heterogent och består av aktörer av flera olika slag och storlek, organiserade i olika driftformer och med en varierande ägarstruktur (SOU, 2007:24). Den privata delen av veterinärsektorn har

\footnotetext{
${ }^{9}$ Detta stycke innehåller delvis text från min licentiatavhandling (Appelkvist 2013:22-23).
} 
sedan 1980-talet expanderat i snabb takt, både vad gäller antalet företag och nettoomsättning. Statistik visar att medan antalet distriktsveterinärer i landet i princip har varit oförändrat sedan 1980-talet har antalet företagande veterinärer mellan åren 1978-2004 mer än tredubblats (SCB statistisk årsbok, 1978-2005).

\section{Distriktsveterinärorganisationen, en del av Jordbruksverket}

Distriktsveterinärorganisationen (DVO) spelar på många sätt en viktig roll för veterinärprofessionen i Sverige. Organisationen har under lång tid fungerat som en "Rite de passage" för nyutexaminerade veterinärer och de flesta veterinärer har vid något tillfälle i sin karriär tjänstgjort som "distriktare"(Appelkvist, 2013). Med anledning av detta, och i ett sammanhang där veterinärprofessionen är stadd i förändring blir det därmed viktigt att närmare redogöra för DVO i fråga om organisering, uppdrag och utveckling i ett historiskt perspektiv.

DVO$^{10}$ är en rikstäckande aktör och finns på omkring 100 platser i landet från Tomelilla i söder till Kiruna i norr (Distriktsveterinärerna, 2015). Samtidigt som DVO är en betydande aktör på de regionala marknaderna har organisationen i princip monopol på marknaderna för veterinär fältverksamhet i stora delar av Norrland (SOU, 2007:24). Sverige är indelat i fyra regioner och varje region leds av en regionchef. En region består av flera praktikområden där varje praktikområde leds av en klinikchef som är ansvarig inför regionchefen. Praktikområdena i sin tur består vanligen av flera mottagningar. Varje mottagning ansvarar för att ge service främst inom det egna geografiskt fastställda området (Jordbruksverket, 2015). Inom DVO arbetar för tillfället cirka 298 tillsvidareanställda distriktsveterinärer (varav 233 kvinnor och 65 män) enligt Jordbruksverkets årsredovisning (2015).

DVOs verksamhet finansieras i huvudsak med avgifter och statliga anslag och har en årlig omsättning på 500 miljoner kronor (Distriktsveterinärerna, 2015). Huvuduppgiften är att tillhandahålla rikstäckande akut djursjukvård, epizootiberedskap samt att bedriva förebyggande djurhälsovård för alla djur i människans vård. Ett beslut som har tagits av Jordbruksverket är att distriktsveterinärerna inte ska erbjuda stationär vård. Detta innebär i sin tur att endast sådan utrustning som används vid primärvård får användas (Jordbruksverket, 2014).

Vad gäller verksamhetsinriktning för de olika djurslagen är uppdraget att (Jordbruksverket, 2014):

Vara en komplett leverantör av veterinär service för lantbrukets djur.

\footnotetext{
${ }_{10}$ Detta stycke innehåller delvis text från min licentiatavhandling (Appelkvist 2013:18-19)
} 
Vara en komplett leverantör av ambulerande veterinär service samt hålla ett nätverk av mottagningar för häst.

Vara en allsidig leverantör av veterinär service på primärvårdsnivå (från vilken svårare fall eller patienter som behöver stationär vård remitteras) för sällskapsdjur.

Veterinärerna som arbetar inom DVO är i grunden oftast allmänpraktiker där alla behärskar samtliga vanliga djurslag och åtgärder i en beredskapssituation (Jordbruksverket, 2014). En satsning på utvecklingstjänster för nyutbildade veterinärer, innebär att veterinärerna under 2 år deltar i utbildning 25 procent av tiden. Syftet med tjänsterna är att förbereda nyutexaminerade veterinärer för livet som distriktsveterinärer. Inom distriktsveterinärerna hanteras även ett stort antal vikarier, bland annat för att upprätthålla dygnet-runt-bemanning under jour och beredskap. Belastningen på den kliniska verksamheten ökar under sommaren när många företagare tar ut ledighet. Veterinärstudenter är vanliga som sommarvikarier och sedan flera år tillbaka erbjuds de i samarbete med SLU praktisk klinisk undervisning hos distriktsveterinärerna (Jordbruksverket, 2014).

Distriktsveterinärerna ${ }^{11}$ arbetar med såväl lantbruksdjur, sällskapsdjur som hästar ${ }^{12}$. Verksamheten har dock kommit att alltmer inriktas mot djursjukvård för sällskapsdjur och häst. Under perioden 2000-2005 har andelen tjänsteärenden avseende lantbruksdjur minskat från 39 till 28 procent medan det har skett en ökning av sällskapsdjur från 45 till 53 procent och för häst från 16 till 19 procent (SOU, 2007:24). Enligt Jordbruksverkets årsredovisning utfördes 50032 tjänsteärenden på lantbruksdjur av distriktsveterinärerna under år 2014. Det kan jämföras med 54175 tjänsteärenden på hästar och 169539 tjänsteärenden på sällskapsdjur. De behandlingar som utförs har samtidigt blivit mer omfattande. En ökning av diagnostiska hjälpmedel (t.ex. blodanalys, ultraljud och röntgen) uppges ha höjt kvaliteten i det kliniska arbetet men har även medfört ökade kostnader (Jordbruksverket, 2014).

\section{Utveckling och förändringsarbete}

I en utredning av veterinärväsendet år 1971 förslogs att flerveterinärdistrikt skulle införas och att fler veterinärstationer skulle byggas. I utredningen poängterades att

\footnotetext{
${ }^{11}$ Detta stycke innehåller text från min licentiatavhandling (Appelkvist 2013:20).

${ }^{12}$ Den indelning som är vanligast, vad gäller arbetsområden inom veterinärprofessionen utifrån djurslag, är hästar, sällskapsdjur samt animalieproduktion. Benämningen animalieproduktion används bland annat $\mathrm{i}$ Jordbruksverkets årsredovisningar. Alternativ och enklare benämning, som $\mathrm{i}$ huvudsak har samma innebörd, är Lantbruksdjur. Övriga indelningar är stordjur samt smådjur (där häst ingår i kategorin stordjur), samt lantbruksdjur och sällskapsdjur (där häst ingår i kategorin sällskapsdjur). Jag kommer i denna studie att använda mig av indelningen - lantbruksdjur, sällskapsdjur samt häst.
} 
tjänstgöringsskyldigheten för de statliga veterinärerna $i$ första hand gällde lantbruksdjuren och att skyldigheten att behandla sällskapsdjur endast gällde då övriga åtaganden medgav det. Som följd av utredningens förslag omorganiserades år 1974 distriktsveterinärernas organisation, bland annat bildades veterinärstationer där flera distriktsveterinärer arbetade tillsammans på några ställen (SOU, 2007:24).

I Djurhälsoutredningen från år 1981 konstaterades att staten hade ett övergripande ansvar för djurens hälso- och sjukvård och att statens huvudmannaskap borde fortsätta. Utredningen satte ett tak på 390 anställda veterinärer. I och med år 1982 förändrades DVO genom delfinansiering med djursjukvårdsavgift. Staten inkasserade avgifterna av djurägaren via distriktsveterinären. Omorganisationen och finansieringsformen syftade till att betydligt minska den statliga kostnaden (SOU, 1981:57).

Även 1992 års veterinärutredning föreslog en avveckling av DVO då kostnaderna ansågs för höga. Utredningen förslog privatisering i den södra delen av landet men lade inte några förslag till lösning för den norra delen. Någon avveckling blev dock inte aktuell denna gången heller. I stället genomfördes år 1995 en omorganisering av distriktsveterinärerna. Liksom tidigare var syftet med omorganisationen att i första hand skapa en kostnadseffektiv verksamhet. Förändringarna till följd av omorganisationen infördes relativt snabb och medförde vissa negativa effekter. I delar av DVO uppstod stor irritation och följden blev omfattande avhopp av distriktsveterinärer, som i stället blev företagare (SOU, 2007:24).

Kommentarer i dagstidningarna speglade två olika inställningar till omorganisationen och dess effekt. Veterinärförbundets inställning var att planerna skulle innebära stora försämringar med lägre inkomster för förbundets medlemmar samt högre avgifter för djurägarna (Göteborgs-posten, 1995-06-20). Jordbruksverkets generaldirektör uttryckte däremot att omorganisationen skulle innebära en modern och kostnadseffektiv organisation med mer samlad kompetens och bättre service (Göteborgs-posten, 1995-06-23). De farhågorna inför omorganisationen utgick ifrån de höjda taxorna och vad det skulle kunna innebära; uppsägningar på grund av minskat antal kunder, djur som for illa för att deras ägare inte hade råd med veterinärvård samt minskade inkomster för veterinärerna själva (Helsingborgs Dagblad, 1995-07-01).

Den genomgripande förändringen i DVO under 1990-talet förde med sig motsättningar och ett negativt arbetsklimat mellan distriktsveterinärer och företagare. Erfarenheten från utredningsarbetet med SOU 2007:24 var att företrädare för båda kategorier på olika sätt försökte misskreditera varandra. Påståenden berörde områden som bristande ansvarskänsla och försumlighet i professionsutövningen. Företagarna uppgavs inte ta sitt fulla ansvar för den veterinära jouren och de hänvisade till distriktsveterinärerna när det föll dem in. På detta sätt påstods de "plocka russinen ur 
kakan" och koncentrera sig på de lönsammaste delarna av marknaden. Distriktsveterinärerna i sin tur uppgavs gå utöver sitt uppdrag och med stöd av statliga anslag gå in på den lönsamma verksamheten med sällskapsdjur (SOU, 2007:24).

Grunden ${ }^{13}$ till det utbredda missnöjet var de rådande villkoren för veterinär verksamhet och då framför allt de olika villkoren för statlig respektive privat verksamhet (SOU, 2007:24). Problemställningarna handlade framför allt om: de olika ekonomiska villkoren för privat och statlig veterinärverksamhet; att de statliga distriktsveterinärerna ökade sin verksamhet med sällskapsdjur och hästar, som traditionellt varit de företagande veterinärernas ansvarsområde; Jordbruksverkets dubbla roller $\mathrm{i}$ och med att verket både bedrev klinisk veterinärverksamhet, hade tillsynsuppgifter och andra myndighetsuppgifter som berörde denna verksamhet.

Riksdagens revisorer granskade på eget initiativ år 2002 förhållandena på veterinärmarknaden. De konstaterade att distriktsveterinärernas verksamhet inte på något avgörande sätt avvek från den verksamhet som bedrevs av företagande veterinärer. Däremot låg en betydande skillnad i att de statliga distriktsveterinärerna fick bidrag för att driva sin verksamhet. Företagen måste däremot drivas helt på marknadens villkor. Samtidigt hade de statliga distriktsveterinärerna börjat behandla sällskapsdjur i en allt större utsträckning, något som av tradition skötts av företagande veterinärer (Riksdagens Revisorer, 2002).

Omorganisationen fortsatte under kommande år och en förändring genomfördes bland annat gällande Jordbruksverkets dubbla roller. Distriktsveterinärerna blev en egen avdelning inom Jordbruksverket med avdelningschef, egen budget och enhet för administration. 2000-talet inleddes med att kvinnliga veterinärer för första gången var i majoritet bland de anställda distriktsveterinärerna. Samtidigt medförde en omfattande veterinärbrist särskilda rekryteringsinsatser både inom och utom landet (SOU, 2007:24).

Under ${ }^{14}$ år 2007 lades ännu en veterinärutredning fram. Även denna gång föreslogs, bland annat, en privatisering av den statliga distriktsveterinärorganisationen. Utredningen förslog en privatisering $i$ två etapper i landets södra och djurtätaste delar. Avsikten var att erbjuda personalen att överta veterinärstationerna tillsammans med fordon och inventarier. Under arbetet med veterinärutredningen genomfördes intervjuer med ett antal veterinärer, både statliga och företagare. Insikten från dessa intervjuer var att veterinärprofessionen, för många, alltjämt ses som ett "kall". Intrycket av veterinärerna var dessutom att de $\mathrm{i}$ hög grad var utpräglade

\footnotetext{
${ }^{13}$ Detta samt nästkommande stycke innehåller text från min licentiatavhandling (Appelkvist 2013:21).

${ }^{14}$ Detta stycke innehåller delvis text från min licentiatavhandling (Appelkvist 2013:21).
} 
Kapitel 2: Veterinärprofessionen i Sverige

individualister, med en påtaglig professionsstolthet $\mathrm{i}$ kombination med misstänksamhet mot konkurrenter och myndigheter (SOU, 2007:24).

\section{Sveriges lantbruksuniversitet}

Även utbildningen omorganiserades under denna tidsperiod. Sveriges lantbruksuniversitet (SLU) bildades år 1977 genom en sammanslagning av Lantbrukshögskolan, Skogshögskolan, Veterinärhögskolan, Skogsmästarskolan i Skinnskatteberg samt Veterinärinrättningen i Skara. Veterinärinrättningen i Skara omvandlades sedermera till veterinärhistoriskt museum (Nationalencyklopedin, 2016).

SLU har verksamhet på ett 30-tal orter i landet. Huvudorterna är Ultuna, Umeå, Alnarp och Skara. Vid Ultuna residerar rektor och här finns även den centrala administrationen. Det är här som veterinärutbildningen är förlagd. Utbildningen motsvarar fem och ett halvt års heltidsstudier om totalt $330 \mathrm{hp}$. Antagningen till veterinärutbildningens 100 platser sker en gång per år (Sveriges lantbruksuniversitet, 2015). Vid sidan av DVO som en "Rite de passage" kan även utbildningen vid SLU beskrivas i dessa termer. De flesta veterinärer i Sverige har utbildningen vid SLU som en gemensam grund för insocialisering i professionen.

I bilaga 2 ges en överblick och beskrivning av övriga statliga myndigheter och aktörer inom veterinärprofessionen. 


\section{Professionens numerära feminisering}

No lady...would like to perform those operations which are the almost daily work of the veterinary practitioner... [unless she] is prepared to unsex herself completely.

Editorial från 1897 citerad i Slater and Slater (2000).

Kvinnor som veterinärer har historiskt inte setts med blida ögon som ovanstående citat indikerar. Den första kvinnan som antogs till veterinärutbildningen i Skara var Waldy Bergegren (Hallgren, 1962). Hon blev år 1914 en pionjär i Sverige men även i världen i egenskap av att vara den 10:e kvinnan som blev veterinär (Östensson, 2010). Europas första kvinnliga veterinär, Agnes Sjöberg född 1888 i Finland, föregick Waldy med några få år (Helsingfors universitetsmuseum, 2011).

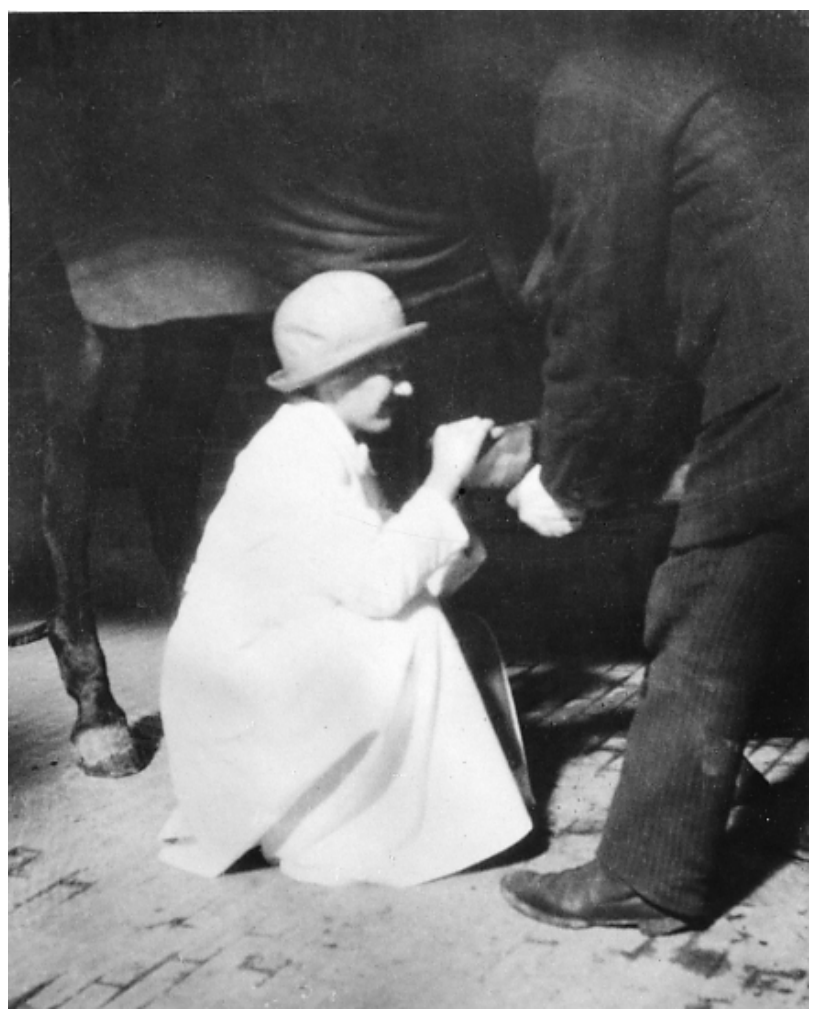

Waldy Bergegren, kirurgiska kliniken 1918

Publicerad med vänligt tillstånd av Veterinärhistoriska museet, Skara. 
Det ${ }^{15}$ dröjde fram till 1930-talet innan fler kvinnor slöt upp i Waldys fotspår (Hellberg, 1978). Utvecklingen tog dock fart efter ytterligare ett par decennier och andelen kvinnor som nya studenter 10-dubblades mellan åren 1955-1970. Första gången som kvinnor utgjorde mer än hälften av de nya studenterna var 1973 och i och med år 1975 var det i Sverige inte längre en stor sak att en kvinna sökte till veterinärutbildningen (Östensson, 2010). I USA har utvecklingen varit snarlik med ett 30-tal kvinnliga veterinärer år 1936 medan siffran år 1963 hade stigit till 277. Under en 10-årsperiod mellan åren 1976-1986 ökade antalet kvinnor som tog examen snabbt, tills de utgjorde 51,5 procent av de examinerade studenterna (Drum \& Whiteley, 1991).

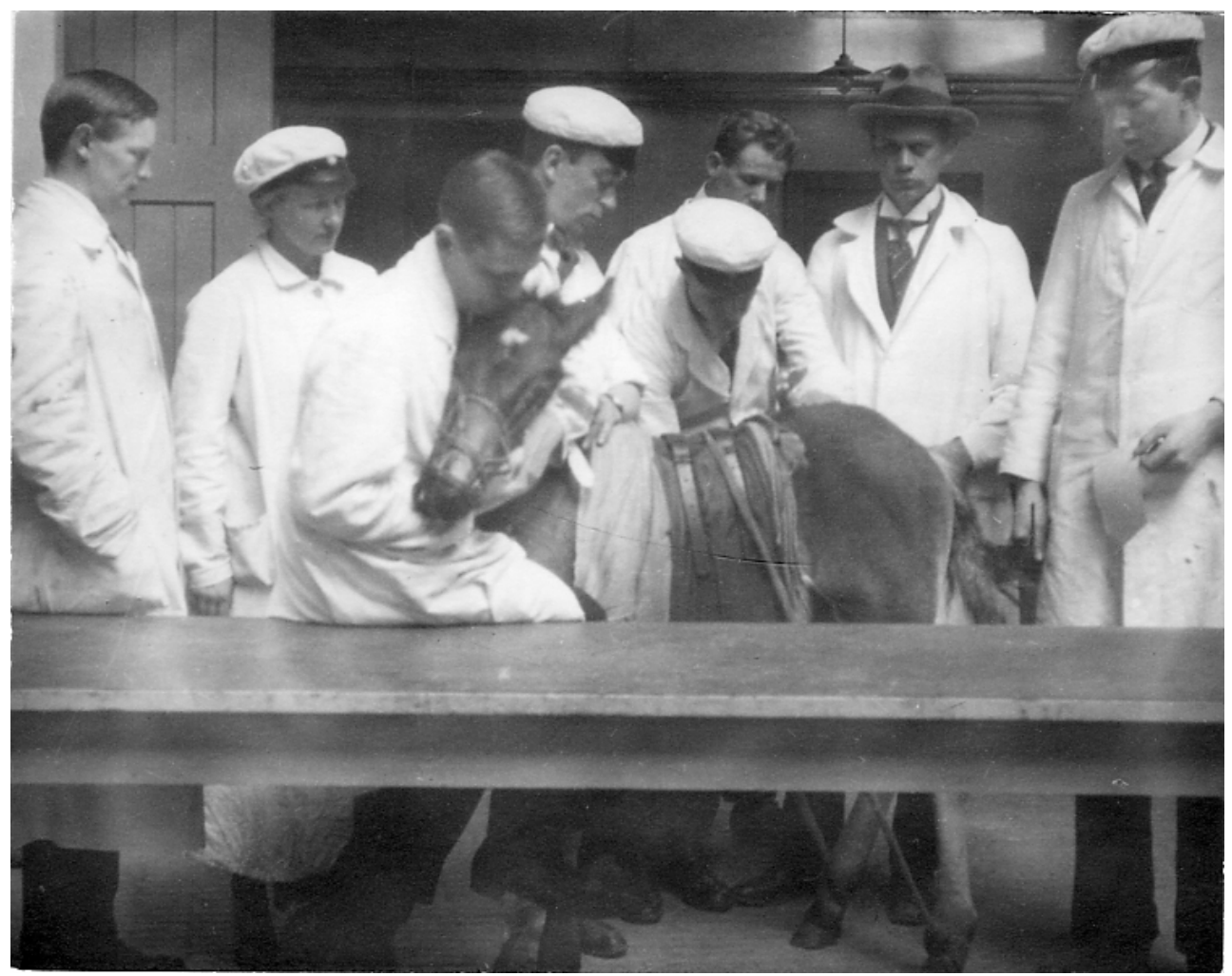

Veterinärstudenter cirka 1914-1919, Waldy Bergegren näst längst till vänster på bilden. Publicerad med vänligt tillstånd av Veterinärhistoriska museet, Skara.

Numera är veterinärprofessionens numerära feminisering ett faktum i Sverige. Kvinnor utgör 77 procent av alla verksamma veterinärer (Saco, 2014) och 88 procent av veterinärstudenterna (Universitets- och högskolerådets antagningsstatistik, 2015).

${ }^{15}$ Detta stycke innehåller text från min licentiatavhandling (Appelkvist 2013:28) 
En svensk studie av yrkens status visar att veterinärprofessionen är det högst placerade (plats 13) yrket där kvinnor är i majoritet (Ulfsdotter Eriksson, 2006).

Veterinärprofessionen är även internationellt ett tydligt exempel på en klassisk profession som har blivit numerärt feminiserad (Irvine \& Vermilya, 2010). I Storbritannien är 55 procent av de verksamma veterinärerna (RCVS, 2012a) respektive 77 procent av veterinärstudenterna kvinnor (RCVS, 2012b). Fördelningen är jämförbar i USA där 55 procent av verksamma veterinärer (AVMA, 2012) och 76 procent av veterinärstudenterna är kvinnor (VMCAS Statistics, 2012).

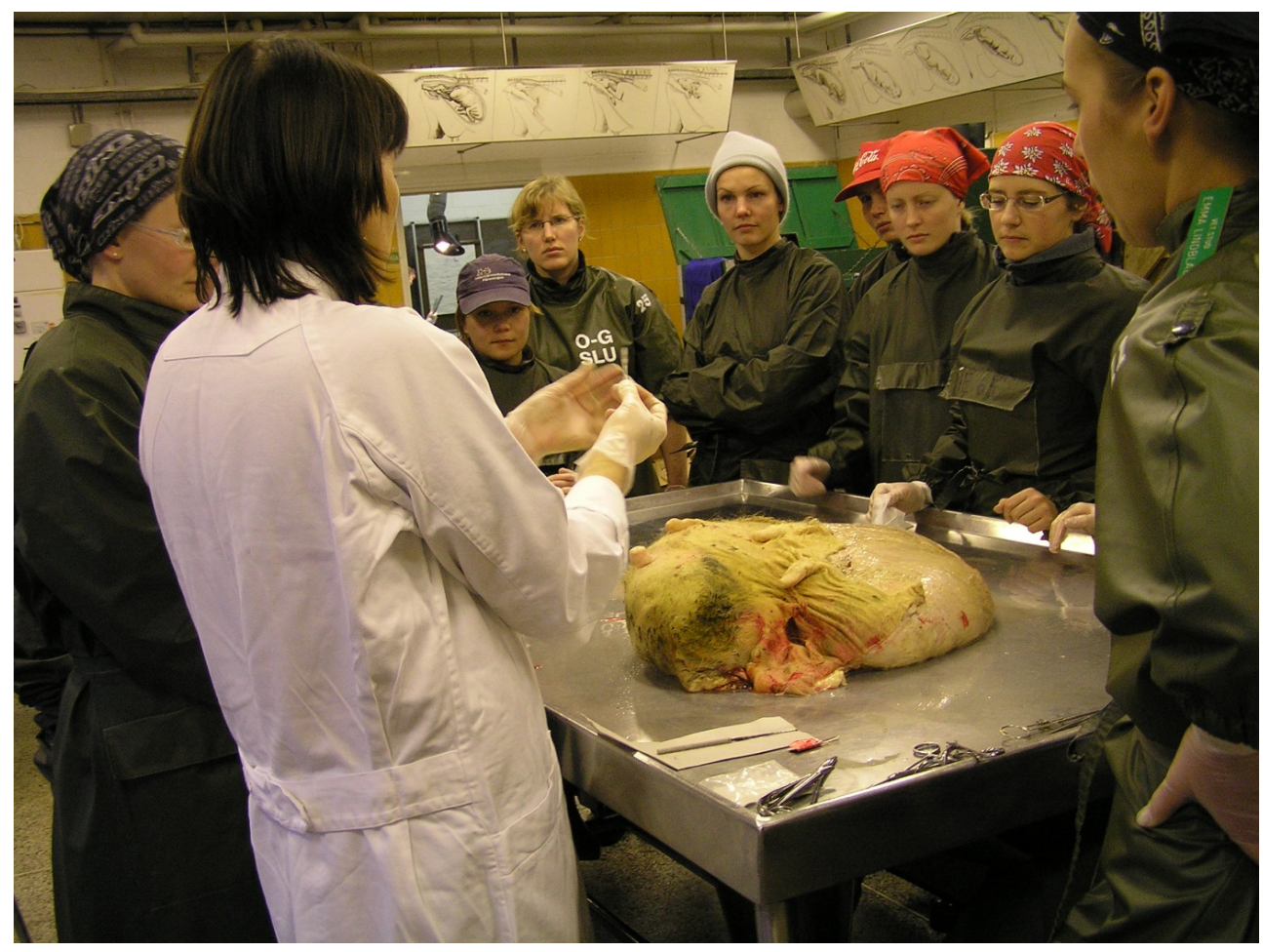

Veterinärstudenter med ett kojuver, 2000-talet.

Publicerad med vänligt tillstånd av Veterinärhistoriska museet, Skara.

Med utgångspunkt i antalet Saco-anslutna medlemmar i Sveriges Veterinärförbund var antalet verksamma veterinärer i Sverige år 2014, 2365 (se tabell 4-1). Av dem var cirka 77 procent kvinnor och 23 procent män. Antalet icke verksamma var i Sverige år 2014, 832 med en fördelning av 44 procent kvinnor och 56 procent män. 
Tabell 2-1: Antal Saco-anslutna medlemmar i Sveriges Veterinärförbund uppdelat på verksamma och icke verksamma

\begin{tabular}{lccccc} 
& Män & \multicolumn{3}{c}{ Kvinnor } \\
& Antal & $\%$ & Antal & $\%$ & Totalt \\
\hline Verksamma & 534 & 23 & 1831 & 77 & 2365 \\
$\begin{array}{l}\text { Icke verksamma } \\
\text { (pensionärer etc.) }\end{array}$ & 465 & 56 & 367 & 44 & 832 \\
Totalt & 999 & 31 & 2198 & 69 & 3197 \\
\hline
\end{tabular}

Källa: Saco (2014)

Den svenska veterinärsektorn kan delas in i tre arbetsmarknadsområden: statligt anställda, privat anställda samt egenföretagare. Tabell 4-2 visar att de verksamma kvinnorna dominerar i samtliga arbetsmarknadsområden men i fallande skala från privat anställd (83\%), till statligt anställd (75\%)och slutligen som egenföretagare (69\%). Siffrorna indikerar att även om kvinnor är i majoritet inom samtliga arbetsmarknadsområden är det vanligare att kvinnor som är veterinärer är privat anställda än företagare medan det omvända gäller för män som är veterinärer.

Tabell 2-2: Antal Saco-anslutna verksamma medlemmar i Sveriges Veterinärförbund uppdelat på arbetsmarknadsområde

\begin{tabular}{lllllc}
\hline & Män & \multicolumn{5}{c}{ Kvinnor } \\
& Antal & $\%$ & Antal & $\%$ & Totalt \\
\hline Stat & 197 & 24 & 615 & 75 & 812 \\
Privat & 170 & 17 & 842 & 83 & 1012 \\
Egenföretagare & 163 & 31 & 364 & 69 & 527 \\
\hline
\end{tabular}

Källa: Saco (2014)

Det $^{16}$ ökande antalet kvinnliga veterinärer har till och från uppmärksammats inom professionen. Skillnaden mellan Sveriges Veterinärförbunds jubileumsskrifter Svensk Veterinärhistoria i ord och bild från 1960-talet och Veterinär - yrke i förändring, från manligt till kvinnligt, från ensamvarg till lagarbetare från år 2010 visar tydligt att något skett. I den förstnämnda skriften nämns Waldy Bergegren endast i en kort bildtext "År 1914 inträffade det oväntade och oerhörda, att en kvinnlig studerande sökte inträde till Veterinärinstitutet" (Hallgren, 1962:87). Numera är det inte ovanligt att förhållandena

\footnotetext{
${ }^{16}$ Detta stycke innehåller delvis text från min licentiatavhandling (Appelkvist 2013:30)
} 
mellan män och kvinnor diskuteras i en rad olika sammanhang. I samband med omorganisationen av DVO i mitten av 1990-talet presenterades omorganisationen i media som en fördel för kvinnliga distriktsveterinärer. Särskilt för de som var småbarnsföräldrar. Fördelen beskrevs vara att omorganisationen innebar nyanställningar och tillkomsten av fler deltidstjänster. Eftersom 80 procent av dem som då utbildade sig till veterinärer var kvinnor bedömdes behovet av föräldraledighet, flexiblare scheman och deltidstjänster öka inom några år (Helsingborgs Dagblad, 1995a). I artikeln med titeln Veterinärer säger upp sig (Helsingborgs Dagblad, 1995b) beskrevs veterinär som ett "nytt kvinnoyrke".

Under åren 2006 och 2007 använde sig SLU av så kallad viktad lottning vid antagningen till veterinärutbildningen. Den viktade lottningen tillämpades inom gruppen för sökande med folkhögskolebetyg. Lottningen innebar i korthet att ju fler sökande som var kvinnor, desto större chans för en man att komma in. I efterhand stämdes SLU för olaglig könsdiskriminering vid antagningen av 44 drabbade kvinnor. SLU fälldes sedermera för att ha diskriminerat kvinnliga sökande till veterinärutbildningen. Tingsrätten ansåg att kvinnor helt hade uteslutits från att komma in på utbildningen efter folkhögskolestudier (Hamrud, 2009; Jällhage, 2008).

\section{Skillnader i lön}

I17 spåren av professionens numerära feminisering har löneskillnaden mellan män och kvinnor ökat påtagligt bland de senast legitimerade veterinärerna (Östensson, 2010) och detta är en trend även internationellt (Felsted, 2000; Smith, 2002). Ett tänkbart skäl som anges är att de unga manliga veterinärerna genom sitt fåtal börjat betraktas som exklusiva och därför ges lönefördelar (SOU, 2007:24).

Enligt den lönekartläggning som genomfördes år 2012 av Saco bland veterinärförbundets medlemmar (bygger på frivilligt lämnade uppgifter) är den svenska veterinärprofessionen vara numerärt feminiserad men det är fortfarande männen som dominerar i löneligan (se tabell 4-3). Medianlönen för en privat anställd manlig veterinär är cirka $45000 \mathrm{kr}$ i månaden, medan en privat anställd kvinnlig veterinär har en medianlön på 35500 kr i månaden. Det är just mellan män och kvinnor som är privat anställda som den största löneskillnaden föreligger. Även bland distriktsveterinärer tjänar män mer än kvinnor men löneskillnaden är bara hälften så stor. En svårighet med att genomföra lönekartläggningar anges vara överrepresentationen av kvinnor bland veterinärerna i Sverige. På många arbetsplatser är männen så få att det skulle vara omöjligt att genomföra en lönekartläggning utan att samtidigt avslöja hur mycket varje enskild man tjänar (Rosell, 2013). Det är även viktigt att

\footnotetext{
17 Detta stycke innehåller text från min licentiatavhandling (Appelkvist 2013:30).
} 
påpeka att denna statistik inte inkluderar ålder som variabel. Det är möjligt att det vi ser i statistiken är en åldersfråga där äldre män har högre lön än unga kvinnor.

Tabell 2-3: Lönekartläggning Veterinärer

\begin{tabular}{llll}
\hline & Män medianlön & Kvinnor medianlön & Skillnad \\
\hline Privat anställda & $45000 \mathrm{kr}$ & $35500 \mathrm{kr}$ & $9500 \mathrm{kr}$ \\
Distriktsveterinärer & $42712 \mathrm{kr}$ & $40350 \mathrm{kr}$ & $2362 \mathrm{kr}$ \\
Samtliga veterinärer & $44600 \mathrm{kr}$ & $38150 \mathrm{kr}$ & $6450 \mathrm{kr}$ \\
\hline
\end{tabular}

Källa: Veterinärmagazinet (Rosell, 2013)

\section{Förklaringar till feminiseringen}

Allt eftersom den numerära feminiseringen av veterinärprofessionens har blivit mer tydlig har olika förklaringar till fenomenet diskuterats. Framför allt fyra förklaringar dominerar i den anglo-saxiska forskningen; (1) Att Kvinnorörelsens kamp för lika rättigheter samt lagstiftning om kvinnors rätt till utbildning lade en grund för kvinnor i utbildningen anges som en grundläggande förklaring och förutsättning (Slater \& Slater, 2000). (2) Även den veterinärmedicinska utvecklingen med såväl utvecklad teknik som effektivare bedövning och lugnande medel förs fram som en förutsättning för att kvinnor skulle klara av att hantera stora djur (Slater \& Slater, 2000). Förändring gjorde att kraven på veterinärens fysiska styrka minskade. (3) Till detta läggs även förklaringar av fler kvinnliga förebilder (Smith, 2002) samt (4) mediebilden av veterinärer som omsorgsfulla och eftertänksamma (här tillskrivs James Herriots böcker och den efterkommande TV-serien "I vår herres hage" en del av äran) (Lofstedt, 2003).

Det är ett faktum att sällskapsdjuren har ökat i antal och fått större betydelse i det svenska samhället. För allt fler människor har just sällskapsdjuren blivit den sinnebild som begreppet djur står för. Omsorg och omvårdnad, som numera kan ses som ledord i veterinärsektorn (såväl i marknadsföring som i media av olika slag) präglar alltmer förhållningssättet till sällskapsdjuren och kan ses som kvinnliga karaktäristika stereotypa för en kvinnlig sektor (Östensson, 2010).

Det $^{18}$ förekommer dock fortfarande att kvinnor anses olämpliga att behandla stora djur såsom lantbruksdjur, till synes enbart på basis av att de ses som maskulint könsmärkta. Denna koppling mellan maskulinitet och stora djur förstärks, åtminstone

\footnotetext{
${ }^{18}$ Detta stycke innehåller delvis text från min licentiatavhandling (Appelkvist 2013:31).
} 
internationellt, ytterligare av att majoriteten av arbetet med lantbruksdjur utförs av manliga veterinärer (Henry, Baillie, \& Treanor, 2010; Lowe, 2010). I Sverige, som nämnts ovan, utgjorde kvinnor 78 procent av distriktsveterinärerna år 2015, den grupp veterinärer som främst arbetar med lantbruksdjur. Som vi har sett minskar dock antalet tjänsteärenden avseende lantbruksdjur för distriktsveterinärerna medan antalet tjänsteärenden avseende sällskapsdjur och häst ökar.

Kategorierna ${ }^{19}$ av lantbruksdjur, sällskapsdjur och häst kan även delas in kategorierna sociala eller ekonomiska djur (Östensson, 2010). Lantbrukets djur är ett tydligt exempel på ekonomiska djur i egenskap av produktionsmedel. Sällskapsdjur såsom hundar och katter beskrivs som sociala djur då deras värde ligger i sällskapet de ger (det finns givetvis undantag i hundar tränade för jakt, assistans etc.). Hästen beskrivs ha en mellanställning då den kan vara antingen ett ekonomiskt eller socialt djur. Östensson (2010) menar att hästen, för unga flickor, har en utpräglad social karaktär, medan hästen för män inom exempelvis hästsporten är mest ekonomisk. Detta kan sättas i relation till det som tidigare visats i detta kapitel, att omsättningen i sektorn stadigt ökat samtidigt som de svenska veterinärerna i allt högre grad behandlar sällskapsdjur snarare än lantbrukets djur.

\section{Sammanfattning}

Strukturella omvandlingar har de senaste hundra åren förändrat det svenska samhället och vi har gått från jordbruk, fiske och grovarbete till en ekonomi som idag till stor del baseras på service och tjänster (Schöön, 2014). I samband med dessa omvandlingar har Sveriges jordbruk de senaste 100 åren gått ifrån att vara en basnäring beroende av djurs och människors muskelkraft till att bli en högteknologisk näring med ett begränsat antal sysselsatta (Flygare \& Isacson, 2003).

Parallellt med jordbrukets omvandling och tjänstesamhällets framväxt har djurhållningen genomgått förändringar (SOU, 2007:24). I princip samtliga slag av lantbruksdjur har minskat betydligt i antal under åren 1980-2005. Samtidigt har sällskapsdjuren ökat i antal, vilket även har påverkat veterinärprofessionen som traditionellt haft en inriktning mot lantbrukets djur. Numera är det sällskapsdjuren som dominerar.

Ursprunget till dagens svenska veterinärprofession uppkom under i slutet av 1700talet (Hallgren, 1962) och har sedan dess etablerats, organiserats och utvecklats löpande. 1900-talet var ett omvälvande århundrade för professionen, inte minst med

\footnotetext{
${ }^{19}$ Detta stycke innehåller delvis text från min licentiatavhandling (Appelkvist 2013:31).
} 
anledning av jordbrukets utveckling. De första distriktsveterinärerna etablerades år 1877 och distriktsveterinärverksamheten förstatligades år 1934 (SOU, 2007:24).

DVO är numera en rikstäckande aktör med huvuduppgift att tillhandahålla rikstäckande akut djursjukvård, epizootiberedskap samt att bedriva förebyggande djurhälsovård för alla djur i människans vård. Verksamheten finansieras av avgifter och statliga anslag (Distriktsveterinärerna, 2015; Jordbruksverket, 2015). Veterinärer inom DVO arbetar med såväl lantbruksdjur, sällskapsdjur som hästar. Verksamheten har dock kommit att alltmer domineras av djursjukvård för sällskapsdjur och häst. DVO har varit föremål för diskussioner om privatisering och nedskärningar vid ett flertal tillfällen men ännu har inga radikala förändringar genomförts (SOU, 2007:24). Organisationen har vid sidan av utbildningen vid SLU under lång tid fungerat som en "Rite de passage" för nyutexaminerade veterinärer (Appelkvist, 2013).

Veterinärprofessionen i Sverige präglas av en numerär feminisering (jmf Saco, 2014). Pionjären Waldy Bergegren blev antagen till veterinärutbildningen i Skara redan år 1914 (Hallgren, 1962). Det dröjde dock ända fram till 1930-talet innan fler kvinnor antogs till veterinärutbildningen (Hellberg, 1978). Andelen kvinnor som nya studenter tiodubblades mellan åren 1955-1970 och kvinnor utgjorde mer än hälften av de nya studenterna redan år 1973 (Östensson, 2010). Antalet verksamma veterinärer i Sverige år 2014 uppgick till 2365 (varav 77 \% kvinnor och 23 \% män). Kvinnor är i majoritet generellt men det är vanligare att de är privat anställda än företagare (Saco, 2014). Samtidigt föreligger en löneskillnad mellan män och kvinnor i professionen, den är som störst vad gäller privat anställda.

Allt eftersom veterinärprofessionen numerärt feminiserats förs olika förklaringar till fenomenet fram. Främst fyra orsaker dominerar i den anglo-saxiska forskningen (Lofstedt, 2003; Slater \& Slater, 2000; Smith, 2002): (1) Rätt till högre utbildning, (2) utvecklingen av bedövning och lugnande medel som underlättar hantering av stora djur, (3) förekomsten av kvinnliga förebilder samt (4) mediabilden av veterinären som omsorgsfull. 


\section{Kapitel 3}

\section{Teoretisk referensram}

$\mathcal{O}_{\text {fat }}$ tudiens teoretiska referensram redogörs för i detta kapitel. Först kommer de tre fälten av småföretagande, profession och genus att introduceras. Därefter närmar jag mig den här avhandlingens specifika fokusområde genom att diskutera den forskning som gjorts gällande överlappningarna mellan de olika fälten, två och två (se figur 1-1). Till sist presenteras den forskning som relaterar till skärningspunkten mellan de tre forskningsfälten. Kapitlet avslutas med en sammanfattning.

\section{I ntroduktion av de tre forskningsfälten}

I det här avsnittet introducerar jag läsaren till de tre forskningsfälten samt diskuterar och definierar avhandlingens centrala begrepp. Jag introducerar i tur och ordning viktiga ställningstaganden inom ramen för fälten småföretagande, profession och genus.

\section{Småföretagande}

I en tid där småföretagande och entreprenörskap tillskrivs en allt större betydelse för samhällets ekonomi används begreppen i dagligt tal som jämbördiga och utbytbara. Att alla entreprenörer inte är företagare och att alla företagare inte är entreprenörer är något som ofta glöms bort (Sundin, 2003). Denna oklara gräns mellan begreppen influerar även forskningen. I synnerhet i engelskspråkig litteratur används "entrepreneur" även då det är "business owner" som avses. Detta har resulterat i att forskningsområdena till stor del överlappar varandra (Bridge \& O'Neill, 2012; 
Landström, 2010). Ett exempel är de återkommande forskningsrapporterna Global Entrepreneurship Monitor (GEM). I dessa rapporter kartläggs entreprenöriell aktivitet i ett stort antal länder utifrån data om företag från och med planerad företagsstart tills företaget har funnits $\mathrm{i}$ tre och ett halvt år. Entreprenörskap mäts alltså genom företagsstart, och företag startar i normalfallet som småföretag. Det innebär att det som presenteras som en kartläggning av entreprenörskap i praktiken blir en kartläggning av nya småföretag (jmf Sternberg \& Wennekers, 2005).

När en differentiering mellan företagande och entreprenörskap görs i forskningen lyfts entreprenörskap och entreprenören ofta fram som nyskapande och innovativ medan företagaren får en mer traditionell om än allomfattande roll (Acs, 2006; Bridge \& O'Neill, 2012). I denna avhandling kommer fokus att ligga på småföretagande. I hur hög grad företagarna är entreprenöriella, i den meningen att de realiserar nya idéer och kombinationer (Schumpeter, 1934/1994), har inte varit studiens fokus. Eftersom fälten är överlappande kommer jag dock även inkludera teorier om entreprenörskap där dessa är tillämpbara.

Att definiera vem som är företagare kan dock vara nog så problematiskt. Företagande är en komplex och strukturellt inbäddad socioekonomisk aktivitet som är föremål för ett antal hinder och fördomar (Marlow, 2014). Vem som är företagare beror på vem man frågar. Myndigheter, gemene man eller företagaren själv kan ha olika sätt att se på saken. Det är inte ens självklart att den som är företagare enligt myndigheter och gemene man är det i sina egna ögon (Sundin, 2010). I den här studien har jag, som framgår av metodkapitlet, intervjuat personer som är företagare i myndigheternas mening.

I Sverige tog forskningen om småföretagande fart på allvar under 1960-talet. Primärt inriktades denna forskning mot att beskriva småföretagens struktur och speciella behov (Landström, 2010). För att skapa en allmän bild av forskningsfältet har det ägnats stort intresse åt exempelvis vad som gör att företag uppstår. En vanlig uppdelning i sammanhanget är företag-företagare-företagsamhet (Johannisson \& Lindmark, 1996b).

Småföretags- och entreprenörskapsforskningen kan kritiseras för att rikta uppmärksamheten mot individen (företagaren) som analysenhet och förklaringsnivå (Blackburn \& Kovalainen, 2009). Detta fokus på individen och dennes egenskaper var något som bland andra William Gartner (1989) vände sig emot i sin numera klassiska artikel: "'Who is an Entrepreneur?' Is the Wrong Question". Det viktiga menade han är att studera vad entreprenören gör snarare än vem entreprenören är. Detta för att komma bort ifrån tendenserna till att entreprenören utmålas som en solitär och som någon som är ensam ansvarig för sin framgång. Denna individs egenskaper beskrivs inte sällan som "larger than life" och i heroiska ordalag. Vad hjälten gör är dock ofta 
höljt i dunkel, menar Gartner (1989). I den här avhandlingen inspireras jag av det synsättet såtillvida att jag intresserar mig för processer snarare än egenskaper.

Småföretags- och entreprenörskapsforskningen har delvis vuxit fram utifrån det samhälleliga och politiska intresset för sysselsättningstillväxt. Forskningen har dominerats av finansiella och nationalekonomiska perspektiv och förklaringar där företagare och entreprenörer ofta framställs som rationella, objektiva och könsneutrala (Acs, 2006; Gandemo, 1996). Möjligheter och hinder för företagande och tillväxt kopplas till utformningen av den ekonomiska politiken och bygger bl.a. på antaganden om att lösningen finns i dynamiska och växande marknader (jmf Braunerhjelm, 2007). En rapport från Tillväxtverket (2012b) visar att de flesta av Sveriges småföretagare svarar "Ja" när de tillfrågas om de vill att deras företag ska växa. Samtidigt visar forskning att de flesta företag, ägda av såväl kvinnor som män, är och förblir små och endast växer marginellt under sina första levnadsår (Daunfeldt \& Halvarsson, 2011). I linje med detta visar en annan rapport från Tillväxtverket (2012a) att de vanligaste skälen till att vilja bli företagare är möjligheten till självständigt arbete och att förverkliga idéer. Att tjäna pengar samt status är de skäl som hamnar längst ned på listan över drivkrafter.

\section{Profession}

Professionen tillskrivs stor vikt i denna avhandling och kommer att introduceras närmare nedan. Det förekommer en mängd definitioner och klassificeringar av vad som utgör en profession. Begreppet ${ }^{20}$ profession avser enligt Molander och Terum (2008) en yrkesmässig organisering av arbete. Det är genom denna organisering som personer med viss utbildning ges rätten att utföra särskilda arbetsuppgifter. Grunden för att ges denna rätt ligger $i$ att arbetsuppgifternas sociala betydelse erkänns samt att det finns en tillit till att professionen kan garantera att uppgifterna blir utförda i enlighet med standarden för god yrkesutövning. Ett samhällskontrakt sluts mellan professionen och samhället, där professionen förpliktigar sig att tjäna vissa allmänna intressen. Det blir därmed viktigt för professionen att uppfylla det samhällskontrakt som åläggs den - detta blir en del i dess existensberättigande (Freidson, 2001; Molander \& Terum, 2008). Detta tar sig ofta uttryck i sanktioner från statens sida i form av en övervakning av professionens utbildning samt genom att auktorisationer utfärdas (Abrahamsson, 1986).

Autonomi är ett annat grundläggande kriterium. Detta innebär att professionen, på basis av den kunskap som den förvaltar, har definitionsföreträde för standarden och utförandet av arbetsuppgifterna. Monopol på kunskap är av yttersta vikt då detta

\footnotetext{
${ }^{20}$ Innehållet under denna rubrik är delvis text från min licentiatavhandling (Appelkvist, 2013:61-64)
} 
innebär att professionen kan monopolisera en viss/vissa yrkespositioner (Freidson, 2001; Molander \& Terum, 2008). Dessa kriterier av kunskapsmonopol och autonomi lägger grunden för att professionen har goda förutsättningar för företagande då de kontrollerar arbetsområdet; affärsidén delvis är given och barriären för att starta företag därmed är låg (jmf Gustavsson \& Rönnqvist, 2004; Hytti, 2003). Jurisdiktionen blir en länk mellan professionen och dess arbete (Abbott, 1988) både som anställd och företagare. Ytterligare kriterier som vanligen lyfts fram för att markera professionens särställning är att medlemmar bekänner sig till en uppsättning etiska normer samt att det finns en markerad kåranda. Grunden till kåranda läggs bland annat genom att vissa kandidater sorteras bort vid rekrytering och genom utbildningen (Abrahamsson, 1986).

Professioner kan delas in utifrån vilken typ av kunskap de fokuserar. Hellberg (1999) skiljer mellan kunskap som handlar om människan eller det levande i allmänhet (Lkunskap) och kunskap om tingen (T-kunskap). Utifrån denna kunskapsindelning ser författaren två olika kategorier av professioner med olika förutsättningar att organisera sitt arbete. Inom L-professionen finns i huvudsak bara en utbildningsväg som kombineras med ett statligt legitimitetsförfarande genom auktorisation. Lprofessioner utövar dessutom sitt yrke gentemot klienter som de står i direkt kontakt med. T-professioners utbildningar finns på flera olika nivåer och även utbildningar utanför det offentliga utbildningssystemet existerar här (Hellberg, 1999). Tprofessioner har inget legitimationsförfarande som en markering på den professionella statusen. Däremot använder man sig av en egen auktorisering, medlemskap i yrkesförbund och titlar. Inom T-professioner utövas yrket mot organisationer så som den direkta klienten.

Professioner och yrkesgrupper kan, i förhållande till varandra, ses som relativa snarare än absoluta enheter (McMurray, 2011). Yrkesgrupper kan beskrivas som ett sätt att dela upp arbete i samhället i grupper där individerna har gemensamma roller och funktioner som åtskiljer deras aktiviteter från vad andra gör, i utbyte mot pengar (Hughes, 1984). Professioner kan sägas skilja sig från yrkesgrupper i grad snarare än typ och representerar en mer priviligierad position som andra yrkesgrupper eftersträvar (McMurray, 2011). När en yrkesgrupp beskriver sig själv som en profession uttrycker detta en självbild och det kan ses som ett försök att övertyga andra om gruppens betydelse och rätt (Molander \& Terum, 2008).

Ovanstående är endast generella karaktäristika för en profession. Olika professioner, men även yrken, kan därmed befinna sig på ett kontinuum med fler eller färre, mer eller mindre starka karaktäristiska (McMurray, 2011; Molander \& Terum, 2008). Professionerna är med andra ord snarare heterogena än homogena; det vill säga de är olika och därmed åtskiljbara från varandra (jmf Bögenhold, Heinonen, \& Akola, 2014). 
I föreliggande avhandling är kopplingen till faktiska historiska förhållanden men även nutida förhållanden i samhället av stor vikt.

\section{Genus}

I denna avhandling använder jag mig av både kön och genus som begrepp. Därmed blir det viktigt att förtydliga vad som skiljer dessa åt. Avsikten med begreppen är att tydliggöra skillnaden mellan kön såsom biologiskt och genus såsom något som är socialt och kulturellt konstruerat (Hirdman, 1988; Åsberg, 1998).

Begreppet genussystem introducerades i Sverige av historikern Yvonne Hirdman 1988. Begreppet har även haft stor genomslagskraft internationellt (Se Ridgeway \& Correll, 2004; Ridgeway \& Smith-Lovin, 1999). Genussystemet kan ses som ett sätt att beskriva och belysa maktrelationer mellan könen på en strukturell nivå. På samma sätt som varje samhälle har en ekonomisk struktur finns där även en genusstruktur. Genussystemet kan på detta sätt ses som ett av de samhällsbärande maktsystemen (SOU, 1990:44).

Två principer som är tätt knutna till genussystemet och som kan sägas utgöra basen för systemet är segregering och hierarkisering (Hirdman, 1988). Segregering avser de krafter som verkar för att hålla män och kvinnor åtskilda. Hierarkisering avser de krafter som tar utgångspunkt $\mathrm{i}$ att mannen är normen och ses som det som är normalt och allmängiltigt medan kvinnan konstrueras som den andra, den som ses som avvikande. Dessa två principer kan ses som tätt sammanvävda och influerar varandra då åtskillnaden mellan könen legitimeras genom antagandet om mannen som norm.

Segregeringen ${ }^{21}$ har i forskningen vidare konceptualiserats och brutits ned till tre olika dimensioner när det gäller att beskriva kvinnors och mäns positioner på arbetsmarknaden (Wahl, Holgersson, Höök, \& Linghag, 2011). I dessa sammanhang talar man om horisontell, vertikal samt intern könssegregering. Den horisontella könssegregeringen tar sig uttryck i en åtskillnad av kvinnor och män i olika sektorer (ex. offentlig respektive privat) eller yrken (ex. frisör respektive elektriker). Den vertikala könssegregeringen illustrerar snarare hur kvinnors och mäns uppgifter är placerade i organisatoriska hierarkier. Kvinnors positioner återfinns generellt på lägre och mellannivåer i organisationer och mäns på mellannivåer och i toppen. Resultatet blir att kvinnor och män inte har samma möjligheter att göra karriär. Detta benämns ibland inom forskning som "glastaket" (Morrison \& Von Glinow, 1990). Andra relaterade termer är "glasväggar" (Miller, Kerr, \& Reid, 1999) såsom hinder för kvinnors tillgång till olika typer av arbeten och "klibbigt golv" (Booth, Francesconi, \&

${ }^{21}$ Detta stycke innehåller delvis text från min licentiatavhandling (Appelkvist, 2013:72-73) 
Frank, 2003) som innebär att kvinnorna längst ned i hierarkin möts av flera nackdelar och ett större lönegap än män. Intern könssegregering innebär att kvinnor och män i samma yrken och/eller på samma arbetsplats tilldelas olika arbetsuppgifter eller väljer olika specialiseringar och inriktningar i sitt arbete (Wahl et al., 2011).

Genussystemet som begrepp har kritiseras för ett inbyggt förgivettagande av förtryck och maktförskjutning mellan könen (Risman, 2009; Thurén, 1996). En hierarkisk ordning mellan könen blir en utgångspunkt för genussystemet. Risken med detta är att vi inte kan se när genussystemets segregerande och hierarkiserande principer utmanas. Det är viktigt att vara medveten om att genussystemets inflytande kan variera och förändras. Det kan vara mer eller mindre starkt, utbrett och hierarkiskt och är inte statiskt (Risman, 2009; Thurén, 1996).

Ytterligare en vanlig kritik av begreppet genussystem och dess tillämpning tar utgångspunkt i debatten om struktur och aktör. Kritiken avser att aktörerna osynliggörs i förhållande till strukturen då begreppet genussystem implicerar determinism (jmf Wetterberg, 1992; Åsberg, 1998). Det vill säga att vi som individer är utelämnade till, och hjälplösa inför, ett system som vi inte kan förändra. Hirdman (1988:51) påpekar dock själv att genus är något som görs: "Jag förslår att vi med genus sätter namn på den alltmer komplicerade kunskap vi har om manligt och kvinnligt, vår allt större förståelse av hur manligt och kvinnligt görs. (...) Genus kan förstås som föränderliga tankefigurer män och kvinnor vilka ger upphov till/skapar föreställningar och sociala praktiker (...)”. Att se beroendeförhållandet och komplexiteten mellan struktur och aktör ser jag som konstruktivt för studiens syfte. Som Kvande (2003:33) uttrycker det: "One might at times need to put a damper on the optimism generated by focusing on agency, but in the next instant need to calm down the pessimism generated by focusing on structure".

Genus som process kan uttryckas på en rad olika sätt, till exempel som något som görs, konstrueras, formas eller skapas. Begreppet "doing gender", vilket fick sitt stora genomslag i och med West och Zimmermans (1987) klassiska artikel med samma namn, används numera ofta som ett samlande begrepp för teorier som tar sin utgångspunkt $\mathrm{i}$ att genus konstrueras socialt (Wahl et al., 2011). Samlingsbegreppet "doing gender" används på olika sätt i olika teoretiska traditioner (Nentwich \& Kelan, 2014).

Med begreppet "doing gender" poängteras betydelsen av att betrakta genus som något som ständigt skapas; i interaktioner mellan människor samt i relation till en viss kontext (West \& Zimmerman, 1987). Här betonas en öppenhet för variationer i konstruktionen av genus och för möjligheter till förändring. En central del är hur genus skapas i situationen/interaktionen snarare än existerar á priori (jmf Kelan \& Nentwich, 
2009). Genus är något som vi alla gör, rutinmässigt, i vår vardag (varje dag, hela tiden). På detta sätt, som en ständigt pågående aktivitet, är det något som vi inte kan undvika.

Både män och kvinnor, pojkar och flickor, är delaktiga i att skapa genuspraktiker i vardagen, enligt West och Zimmerman (1987). Dessa genuspraktiker vävs in i sociala interaktioner på ett sätt som gör dem omöjliga att komma ifrån. Vi gör genus samtidigt som vi är medvetna om att vi, i vårt eget görande, kommer att bli bedömda av andra. Vi hålls därmed ansvariga (accountable ${ }^{22}$ ) av andra för hur vi gör genus. Flickor och pojkar lär sig, från tidig ålder, vad som är ett lämpligt beteende för en pojke respektive en flicka och vad som är passande enligt ett normativt beteende. Värt att notera är att vårt görande av genus inte alltid är i linje med de normativa uppfattningar som finns om vad som är feminint och maskulint. "Doing gender" inkluderar även det görande som kan ses som riskabelt eller avvikande. De individer och grupper vars görande av genus faller utanför normen utmanar därmed traditionella genusstrukturer (West \& Zimmerman, 1987). För en fördjupning av "doing gender" som perspektiv se exempelvis Korvajärvi $(1998,2003)$.

Som med många teoretiska begrepp riktas nu kritik mot hur man i forskningen har nyttjat begreppet "doing gender" och urholkat det. Ett problem som förs fram är att begreppet ständigt kopplas samman med forskning där genussystemets uthållighet på ett eller annat sätt bekräftas (Deutsch, 2007). På så sätt kopplas innebörden allt mer till att det illustrerar en till synes oundviklig ojämställdhet. I linje med detta har bland annat "degendering" förts fram som alternativt begrepp (Lorber, 2005). Deutsch (2007) menar att "doing gender" bör reserveras för interaktioner som återskapar genus och att "undoing gender" bör nyttjas för interaktioner där genusskillnader reduceras. Den klassiska artikeln "Doing gender" har senare omarbetats av West och Fenstermaker (1995) som svar på kritik. I sin nya tappning har dock begreppet fortsatt kritiserats, bland annat för att ta otillräcklig hänsyn till strukturer (Collins et al., 1995).

"Doing gender", som jag tolkar det med grund i West och Zimmerman (1987), handlar dock inte om att det genus som görs endast återskapar och befäster genussystemet. Begreppet innefattar såväl stabilitet som förändring. Det inbegriper möjligheter till att återskapa och befästa men även till att göra om och förändra, samt öppnar upp för en sensitivitet för komplexitet och förändring i olika sammanhang (jmf Gunnarsson, Andersson, Vänje Rosell, Lethto, \& Salminen-Karlsson, 2003; Korvajärvi, 1998, 2003). Det är i detta vi bör ta utgångspunkt och vi behöver återerövra "doing gender" som ett öppet begrepp snarare än begränsa och förminska det. Jag instämmer dock med Deutsch (2007:107); "It is time to put the spotlight squarely on the social processes that underlie resistance against conventional gender relations and on how successful

\footnotetext{
${ }^{22}$ Detta är det begrepp som författarna använder och som jag valt att översätta till ansvariga
} 
change in the power dynamics and inequities between men and women can be accomplished".

Med utgångspunkt i "doing gender" formulerar Fogelberg Eriksson (2004) liknelsen "glipor i mönstret". Med denna liknelse avser hon processer där genussystemets traditionella mönster utmanas och där förändringar kan skönjas i mönstret. I och med denna liknelse åskådliggörs även genussystemet såsom en struktur som är möjlig att förändra. Med glipor avses situationer eller processer som på ett eller annat sätt kan fungera som utmanare till genussystemet och de traditionella mönster som skapas genom detta. Gliporna handlar om varianter och variationer exempelvis i konstruktionen av manlighet och om situationer där stereotypa uppfattningar om kvinnlighet utmanas. I den här avhandlingen använder jag i likhet med Fogelberg Eriksson (2004) perspektivet "doing gender", för att synliggöra glipor ${ }^{23}$ i mönstret samt öppna upp för en möjlighet att analysera och förstå både stabilitet och förändring i förhållande till genus. Som nämndes i introduktionen kommer jag huvudsakligen att använda det svenska uttrycket; att göra genus.

\section{Forskningsfältens överlappningar}

I det här avsnittet närmar jag mig avhandlingens kärna genom att diskutera tidigare forskning som relaterar till flera av ovan beskrivna forskningsfält. Avsnittet är indelat i tre delar (jmf fältens överlappningar som illustreras i figur 1:1). Första delen nedan behandlar forskning om kvinnors företagande, som alltså berör fälten småföretagande och genus. Den andra delen diskuterar den tidigare forskning som jag sedan använder för att analysera företagande i en profession inklusive teoribildningen om företagande och livsform. I tredje delen av detta avsnitt presenteras och diskuteras tidigare forskning om profession och genus.

\section{Kvinnors företagande}

Historiskt är inte kvinnors företagande ett nytt fenomen. Kvinnor har snarare alltid, på ett eller annat sätt, varit företagare (Holmquist \& Sundin, 2002). Även då det var i det närmaste förbjudet för dem att driva företag gjordes undantag för änkor i vissa sammanhang under 1700-talet i Sverige (Sundin \& Holmquist, 1989). I en pionjärstudie av kvinnors företagande visade Sundin och Holmquist (1989) att 25 procent av Sveriges företagare var kvinnor samt att deras företagande kunde beskrivas utifrån nyckelorden osynlighet, mångfald och anpassning. Det har visat sig att dessa

\footnotetext{
${ }^{23}$ Med glipa avses, i likhet med Fogelberg Eriksson (2004), ett smalt mellanrum på grund av att något inte sluter tätt.
} 
nyckelord är valida även på 2000-talet (Sundin \& Tillmar, 2010a). Sundin och Holmquists (1989) studie var den första studie som med hjälp av bland annat information från Folk- och bostadsräkningen visade det som tidigare varit osynligt $\mathrm{i}$ det dåvarande företagarregistret - att kvinnor till en större utsträckning än vad man dittills trott utgjorde en ansenlig del av landets företagare. Studien visade att den typiska kvinnliga företagaren inte gick att beskriva - hon fanns helt enkelt inte. Det som fanns var ett antal företagare som skilde sig åt på en rad olika områden (ålder, bostadsort, civilstånd, utbildning, bransch etc.). Kvinnors företagande visade sig präglas av mångfald snarare än likformighet. Företagandet visade sig även präglas av en hög grad av anpassning utifrån rådande familjesituation. En slutsats av studien var att kvinnor som företagare inte är en homogen grupp (Sundin \& Holmquist, 1989). Detta är något som även bekräftas av internationella studier (Gatewood, Carter, Brush, Greene, \& Hart, 2003). En av de saker som de kvinnliga företagarna har gemensamt är dock att hindren de möter härrör från genussystemet i samhället (Tillmar, 2007).

Den ovan refererade pionjärstudien blev en stark kontrast till inte minst Boltonrapporten, ansedd som ett pionjärarbete inom entreprenörskaps- och småföretagsforskningen, där det genomgående alluderas till företagaren som en man: "firms are (...) as varied and individual as the men who founded them" (Bolton, 1971:22). Denna genusblindhet präglar en stor del av de teorier och metoder som tidigt utvecklades inom forskningsfältet; de tar sin utgångspunkt i mäns företagande (Stevenson, 1990). Vid tillämpning av dessa teorier på kvinnor, och i jämförelser mellan män och kvinnor, blir de som avviker från normen betraktade som misslyckade. Det vill säga, när kvinnors företagande studeras med hjälp av teorier som tar sin utgångspunkt i mäns företagande framstår det som avvikande och mindre värt (Mirchandani, 1999).

Internationellt har Diana-gruppen varit av stor vikt för forskningen om kvinnors företagande och har utkommit med flera böcker (Brush, Carter, Gatewood, Greene, \& Hart, 2006; Brush, De Bruin, Gatewood, \& Henry, 2010). Senast med fokus på kvinnors företagande i globala och lokala kontexter (Diaz-Garcia, Brush, Gatewood, \& Welter, Kommande). Vad gäller de nya riktningar som bland andra Ahl (2006) förespråkar med bland annat fokus på kontext, icke-essentialism och socialkonstruktionistiska perspektiv ligger skandinaverna i framkant i den typen av forskning (Alsos, Jensen, \& Ljunggren, 2010; Kovalainen \& Arenius, 2006; Pettersson, 2002; Sundin \& Tillmar, 2008).

Kvinnors företagande har i forskningssammanhang ägnats allt större uppmärksamhet de senaste decennierna (Achtenhagen \& Tillmar, 2013). Inte minst har forskningsfältet sammanfattats i ett antal översikter där forskningen om kvinnors företagande erhåller såväl kritik som uppmuntran till att bryta ny mark (Ahl, 2006; Henry, Foss, \& Ahl, 2016; Marlow, 2002; Mirchandani, 1999). I ett globalt perspektiv utgör kvinnor en av 
de snabbast växande grupperna av företagare och är pådrivande i utvecklingen av nya företag (Brush, De Bruin, \& Welter, 2009).

På senare år har statistik visat att kvinnor i större utsträckning än män återfinns inom tjänstesektorer såsom kultur, nöje, fritid och annan service samt vård och omsorg (Tillväxtverket, 2012b). Som ett utslag av den internationella trend som benämns New Public Management (NPM) (Hood, 1995) har konkurrensutsättningen av offentliga verksamheter i Sverige medfört en förändring av välfärdsområdet i form av inslag av privat näringsliv (Hasselbladh \& Bejerot, 2008). Detta antas kunna öppna upp för ett ökat deltagande av kvinnors företagande då kvinnor dominerar som anställda inom exempelvis skola, vård och omsorg (Dahlman, 2004). Forskning har tidigare visat att många startar företag inom branscher där de har tidigare erfarenhet (Shane, 2000; Sundin \& Holmquist, 1989). En avreglering av offentlig sektor har på så sätt framställts som en lösning vad gäller att öka andelen kvinnor som är företagare i Sverige (Dahlman, 2004).

Det har dock visat sig att det inte har varit helt enkelt för mindre företag att hävda sig i konkurrensen som uppstått i samband med avregleringen. Många kvinnor riskerar istället att gå från att vara anställda med låg lön inom offentlig sektor till att driva företag med låg förtjänst (Sundin \& Tillmar, 2010b). Det finns även tendenser till både maskulinisering och oligopolisering i spåren av offentlig sektors omvandling (Sundin \& Tillmar, 2010a). Kvinnors företagande har ökat, men inte i den omfattning som förväntats. Snarare är trenden att överrepresentationen av män som företagare ökar (Sköld, 2013, 2015).

Kvinnor som är företagare kan förenklat delas upp i de som väljer att se genusfrågor och de som väljer att bortse från dem (Lewis, 2006). I den sistnämnda gruppen inkluderas både de som behandlar företagande som en genusneutral företeelse och de som aktivt arbetar för att inte bli identifierade som avvikande. Ironiskt nog bekräftar de på detta vis istället företagandets manliga könsmärkning. Denna så kallade genusblindhet döljer kvinnornas ogynnsamma positioner och genom att upplevelser av könsmärkningen neutraliseras stärks i förlängningen den maskulina normen. Kvinnornas agerande kan ses som ett sätt att försöka undkomma att märkas och konstrueras som "den andra". I sin studie av kvinnor som är företagare i Londonområdet visar Lewis (2006) att det tenderar att uppstå konfliktytor mellan de kvinnor som väljer att se respektive att inte se genusfrågor.

\section{Företagandets könsmärkning}

Män som är företagare presenteras vanligen som just företagare medan kvinnor som är företagare främst presenteras så som kvinnor (Holmquist, 2008). Ett dominerande antagande är att företagaren i "normalfallet" är en man (Ahl, 2006; Ljunggren \& Alsos, 
2007; Sundin, 2002). I fallet med den individfokus som Gartner (1989) kritiserade, och där entreprenören beskrevs i heroiska ordalag, var det stålmannen och inte stålkvinnan som var föremål för beskrivningen. Detta kan ses som ett utslag för genussystemets närvaro i vårt samhälle (jmf Hirdman, 2001). Den könsuppdelningen som är närvarande i både samhälle och arbetsliv är även förhärskande i företagande. Den uppdelning som kännetecknar genussystemet gör att män och kvinnor söker sig till olika fält inom arbetslivet och denna uppdelning fortplantar sig vidare till olika fält inom företagande (Holmquist, 2008). Företagande kan på så sätt sägas präglas av en manlig könsmärkning (Ahl, 2006; Sundin, 2002).

Med könsmärkning avses tillskrivningen av specifika uppgifter, artefakter, språk, kläder och titlar till kvinnor respektive män. Det är ett sätt att förenkla och ordna verkligheten utifrån en struktur. När en ny teknik eller arbetsuppgift introduceras råder inledningsvis ofta en osäkerhet kring om den ska betraktas som i huvudsak manlig eller kvinnlig (Sundin, 1995a). Könsmärkningar kan variera över tid och rum och det som vid en tidpunkt ses som uppgifter lämpade för en man kan vid en annan ha setts som uppgifter lämpade för en kvinna (Bradley, 1989). Detta kan gälla för såväl yrken (jmf Sommestad, 1992), arbetsuppgifter (jmf Abrahamsson, 2004; Lindgren, 1999) och teknik (jmf Sundin, 1995b). Det som dock hålls som konstant är uppdelningen mellan könen och idén om att visst arbete är mer lämpligt för kvinnor och annat mer lämpligt för män (Bradley, 1989, 2013).

Förklaringarna ${ }^{24}$ till företagandets manliga könsmärkning står att finna i såväl kvantitativa som kvalitativa föreställningar och påståenden som präglar företagande och entreprenörskap (Sundin, 2002). En kvantitativ förklaring är att kvinnor deltar i lika stor utsträckning som män på dagens arbetsmarknad men står för endast en fjärdedel av företagarpopulationen. Men även om kvinnor står för en mindre del av företagandet är deras företagande också osynliggjort i statistiken. Utöver detta ges även förklaringar i form av att de arbetsuppgifter som vanligen förknippas med företagare och företagande har en manlig könskodning. I dessa föreställningar inkluderas sådant som ledarskap, som i sig har en manlig könsmärkning (Due Billing \& Alvesson, 1989), och kontakter med långivare. Faktum är dock att detta gäller långt ifrån alla arbetsuppgifter. Det råder dessutom en föreställning om att företagande förutsätter ett stort engagemang. Ett större engagemang än vad en kvinna p.g.a. könsrollerna i samhället anses kunna ha, om engagemang definieras som det antal timmars arbete som kan investeras i företaget. Men engagemang som begrepp har även en innehållslig sida såsom att tro på verksamheten och brinna för idén. Här finns det inga belägg för att kvinnor skulle uppvisa ett lägre engagemang än män. Det paradoxala blir att företagandets könsmärkning enligt detta står på en instabil grund och ändå kvarstår den (Sundin, 2002). Andra forskare förklarar nedvärderingen av

\footnotetext{
${ }^{24}$ Detta stycke samt nästa innehåller delvis text från min licentiatavhandling (Appelkvist, 2013:73-74)
} 
kvinnors företagande med att en majoritet av dessa företag finns i tjänsteproduktionssektorn (Bruni, Gherardi, \& Poggio, 2004). Sektorn, menar författarna, förknippas med enklare arbete där det är låga inträdesbarriärer och låga krav på teknisk kompetens.

Forskningen om kvinnors företagande har i många fall också förstärkt bilden av entreprenören som en man (Ahl, 2004). Genom att dekonstruera bilden av entreprenören visar Ahl (2004) att de egenskaper som förknippas med entreprenörer och förs fram i forskningen går i linje med Bems index ${ }^{25}$. I Bems index lyfts maskulina egenskaper såsom bestämd, målmedveten, oberoende, risktagande, modig, visionär, atletisk och kraftfull etc. Dessa egenskaper ses ofta som motsatsord till feminina egenskaper; osäker, feg, beroende, försiktig, förstående, lojal, empatisk, lyhörd för andras behov etc. Könsmärkningen av entreprenören/företagaren som man skapas och återskapas på detta sätt delvis även i forskningen om kvinnors företagande. Även om skillnader mellan män och kvinnor som är företagare har hittats är likheterna avsevärt fler. Trots detta presenteras kvinnors företag i förhållande till mäns konsekvent som mindre till storlek, i fråga om vinst och inte minst långsammare i fråga om tillväxt. Till detta kan läggas att en norm för prestationen (där prestationen mäts utifrån företagsstorlek, vinst, ökad försäljning samt i antal anställda) åläggs kvinnorna och att denna gör att de betraktas som otillräckliga. Normen blir dessutom dubbelt förtryckande då majoriteten av mäns företag enligt denna kan ses som otillräckliga (Ahl, 2004).

I uppdelningen av, och jämförelsen mellan, män och kvinnor cementeras en syn på kvinnors företagande som bristande och problematiskt och detta föranleder ofta såväl förklaringar till, som lösningar på, problemet (Marlow, 2002). Förklaringarna baseras ofta på stereotypa karaktärsdrag och behandlar kvinnor som en homogen grupp och lösningarna emanerar ofta i att kvinnor behöver utbildas/formas för att bli mer lika män. Lösningar är ofta individualistiskt orienterade, det vill säga ansvaret läggs på aktören (Ahl, 2006). I en nyligen publicerad artikel diskuterar Ahl, Berglund, Pettersson och Tillmar (2016) hur de neoliberala strömningarna påverkar feminismen. Författarna frågar sig huruvida feministisk aktivism i framtiden kommer att ske i företagsform, och myntar begreppet FemInc.ism.

\footnotetext{
${ }^{25}$ Forskaren Sandra Bem utarbetade ett index över egenskaper som kunde anses vara typiskt maskulina respektive feminina. Denna lista reviderades i efterhand för att passa svenska förhållanden (Ahl, 2002).
} 


\section{Småföretagande och profession}

Det har sedan länge uppmärksammats att företagande och entreprenörskap är inbäddat i sin kontext, på ett sätt som har stor betydelse för hur företagandet bedrivs (jmf Morrison, 2006). Kontexter både sätter gränser för och möjliggör individers handlade. I en ambition att skapa överblick över alla de typer av kontext som påverkar företagande listar Welter (2011) den rumsliga, sociala och institutionella kontexten, liksom branschkontexten. I den här avhandlingen fokuseras branschkontexten, här specifikt i termer av professionens roll. Detsamma gäller dock det sociala i termer av hur företagarna väljer att leva sina liv. Även det rumsliga, som här är landsbygden, kommer att diskuteras. Dessa tre sammanvävda kontexter för småföretagande diskuteras nedan.

Flera professioner har goda förutsättningar för företagande i och med kontrollen av kunskap och arbetsområdet vilket gör att affärsidén är delvis given och barriären för att starta företag är låg (Gustavsson \& Rönnqvist, 2004). Jurister, arkitekter, tandläkare och veterinärer är exempel på professioner med en jämförelsevis stor andel företagare (Svensson, 2003). För andra professioner såsom socionomer har eget företagande på senare år förts fram som en professionaliseringsstrategi (Dellgran \& Höjer, 2005). Trots detta råder det brist på studier där professionsteori och teori om småföretagande och entreprenörskap kopplas samman. Här presenterar jag därmed några av de studier som finns, samt övriga studier som används för att analysera företagande i en professionskontext. Till dessa hör framförallt studier av företagande och livsform och företagande på landsbygden. Då profession varit starkt förknippat med hur företagare valt att leva sina liv har livsformsteorin under processens gång visats sig användbar.

En enkätstudie av finska frilansjournalister, översättare, tolkar och konstnärer visar att dessa professioners förutsättningar och företagande varierar beroende på situationen på arbetsmarknaden (Bögenhold, Heinonen, \& Akola, 2014). De undersökta professionerna visar sig vara högst heterogena på detta sätt och en slutsats av studien är att dessa utifrån livs- och arbetssituationen inte kan beskrivas entydigt som vinnare eller förlorare. Många nyanser av socioekonomiska situationer förekomma. Vissa typer av företagare och oberoende professionella tillhör en kategori som inte passar ihop med den stereotypa bilden av entreprenörskap menar författarna.

Att vara företagare kan ses som ett sätt att leva, som en livsform (Bergqvist, 2004; Holmquist \& Sundin, 2002; Lönnbring, 2003). Livsformsteori avser att förklara varför människor fattar olika typer av beslut och tar utgångspunkt $i$ att människor på grund av olika villkor har varierande sätt att hantera och leva sina liv. Detta är något som inverkar på såväl val av boende, barnomsorg och sätt att organisera företag (Lindgren, 2002). Nedan återkommer jag till studier som kombinerat livsformsteori och företagande. 
Begreppet livsform lanserades av forskaren Thomas Höjrup (1983/89) i Danmark på 1980-talet. Sedan dess har en rad empiriska undersökningar gjorts av olika nordiska forskare. Livsformsteorin är främst etablerad och nyttjad i Norden med sina starkaste säten i forskargrupper i Köpenhamn, Karlstad och till viss del även Göteborg. Jag tar i denna studie utgångspunkt i Höjrups klassiska livsformer samt den forskning som gjorts om företagande med hjälp av livformsteori.

Höjrup (1983/89) utvecklade ett analytiskt teoretiska verktyg som inkluderar tre livsformer; självständighetens-, karriärens- och löntagarens livsform. Centralt för dessa livsformer är förhållandet till arbetet, med en betoning på kopplingen mellan livsform och livsvillkor. Självständighetens livsform lägger tonvikt vid arbetet. Dessa individer lever för att arbeta snarare än drivs av storleken på lönen. Gränserna mellan arbete och fritid har en tendens att flyta ihop. Att ha kommandot över sitt eget liv och att inte behöva vara beroende av andra tillskrivs stor vikt. Individer som tillhör löntagarlivsformen arbetar för att leva, det vill säga de ser arbetet som ett medel för att nå målet av en rik fritid. I och med detta skiljer dessa individer strikt mellan arbete och fritid. Karriärlivsformen kan beskrivas som en blandning av de två föregående livsformerna. Arbetet är ett sätt att leva men i likhet med löntagarlivsformen vill dessa individer ha bra betalt för sitt arbete. Dessa individer strävar framåt och uppåt och kan tänka sig att flytta om det skulle gagna deras karriär. Det är möjligt för en person att vara bärare av flera av dessa livsformer samtidigt menar Höjrup (1983/89). Dessa livsformer har kritiserats för att de inte tar hänsyn till kvinnors liv. När begreppen utvecklades av Christensen (1987) formulerades de kvinnliga livsformerna dock främst som komplement till de manliga och grundproblematiken kvarstod.

Livformsteori och företagande har sammanförts i en handfull studier sedan 1980-talet. Nedan kommer jag att närmare redogöra för tre som frekvent citeras. I en klassisk studie som är baserad på engelska förhållanden klassificerade Goffee och Scase (1985) kvinnors företagande utifrån värderingar i form av företagarideal och könsrollsideal. Företagaridealen kännetecknas i denna studie av ekonomisk självständighet, individualism, personligt ansvar och självförtroende. Könsrollsidealen kännetecknas av hur individen anknyter till traditionella bilder av män och kvinnor. Utifrån en matris av dessa två spektrum identifieras fyra typer av kvinnliga företagare (se figur 3-1). 
Anslutning till gängse könsrollsideal

Hög Låg

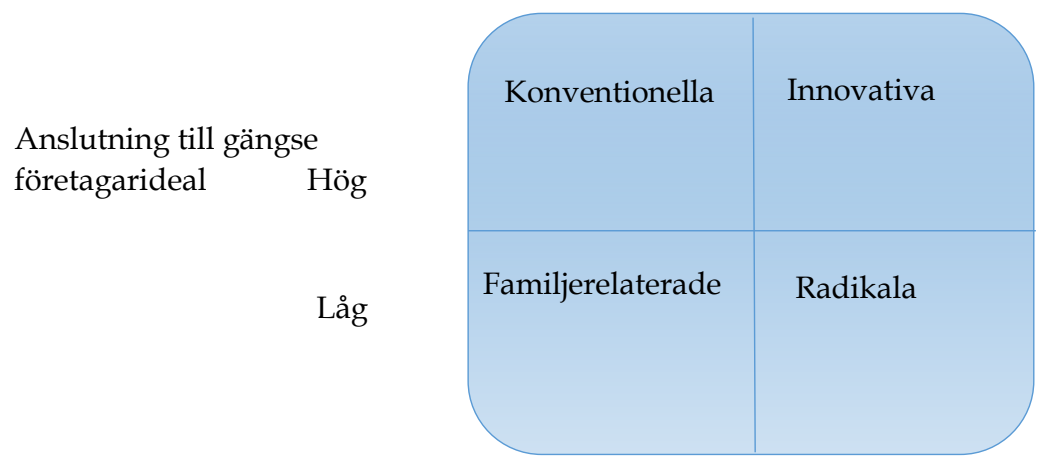

Figur 3-1: Typer av kvinnliga företagare. Goffee och Scase (1985:55)

De konventionella företagarna är vanligtvis gifta, har barn och familjen är det viktigaste i deras liv. Det egna företagandet ses som ett komplement till makens arbete (vilket ses som basen för familjen ekonomiskt och socialt). De innovativa företagarna ser arbetet som det viktigaste i livet och är ofta välutbildade och karriärsdrivna. I denna grupp finns en hög tilltro till individuella drivkrafter som lösningen på genusproblematik. De familjerelaterade företagarna är företagare för att det ger dem en möjlighet att anpassa förläggningen av arbetet i tid och rum till familjens krav och behov. De radikala kan beskrivas som de ofrivilliga företagarna som helst av allt vill utöva sitt yrke. De är ofta högutbildade och har erfarenheter av mäns fördomar från tidigare arbete i storskaliga organisationer (Goffee \& Scase, 1985). Goffee och Scase (1985) poängterar att typologin i hög grad är förenklad och att det finns andra faktorer än företagarideal och könsrollsideal som kan ha stor inverkan på motiven till att starta företag. Dessutom kan en och samma individ tillhöra olika typologier vid olika tillfällen.

I den tidigare nämnda studien av Sundin och Holmquist (1989) använder sig författarna av begreppet livsform och då särskilt löntagarlivsformen, självständighetslivsformen och karriärlivsformen för att diskutera förutsättningarna för kvinnors företagande. Livsformerna delas upp i en traditionell och en modern variant. Utifrån bland annat en tillämpning av ovanstående typologi av Goffee och Scase (1985) på den egna studiens grupper av företagare i en svensk kontext utvecklade Sundin och Holmquist (1989) en typologi över livsformer som de identifierade i sitt material. Till företagarideal och könsrollsideal som grund för att urskilja olika typer av kvinnor som företagare tillförde författarna även 
familjesituationen. Detta då studien visade att kvinnornas familjesituation var av stor betydelse för såväl valet att starta samt för hur de arbetade i sitt företag. Denna mycket detaljerade typologi (Se Sundin \& Holmquist, 1989:144) strukturerades och kondenserades sedermera (se figur 3-2).

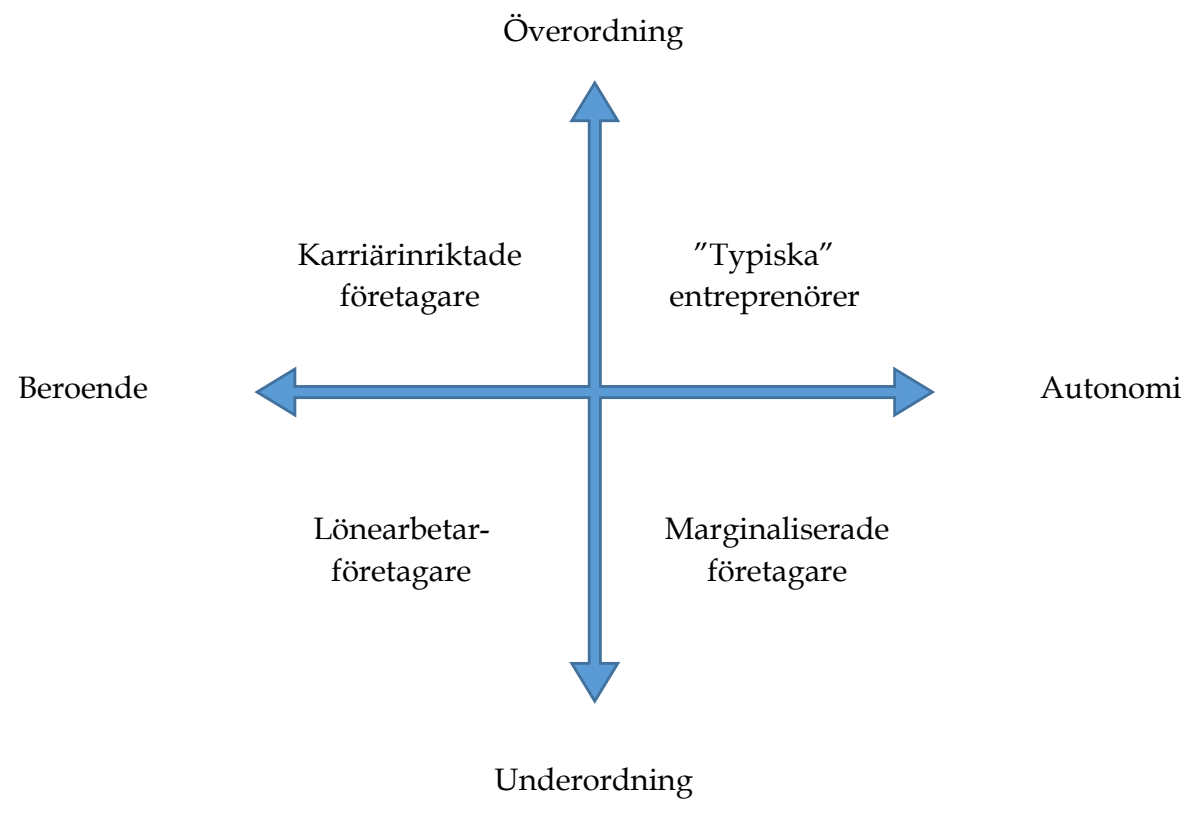

Figur 3-2: Företagande som uttryck för individens position avseende självständighet (beroende - autonomi) och förhandlingsstyrka (överordning - underordning). Sundin och Holmquist (1989:148)

I figuren ges utrymme för flera dimensioner av företagande. Här illustreras hur företagande kan vara ett utryck för överordning och underordning avseende förhandlingsstyrka men även vara ett uttryck för beroende och autonomi avseende självständighet. I och med detta lämnas utrymme för att företagande kan bedrivas på skilda grunder och utifrån olika förutsättningar. Det kan vara en lösning på problem eller ett uttryck för möjligheter. Företagande kvinnor kan vara karriärinriktade och privilegierade men även vara marginaliserade och styrda av nödvändighet. Det finns inte en typ av företagande kvinnor snarare kan gruppen beskrivas i termer av mångfald. Därmed blir det tydligt att kvinnors företagande bör ses i sitt sammanhang.

Lönnbring (2003) identifierar i sin avhandling om kvinnors företagande på den värmländska landsbygden en mångfald av självständigheter. Författaren identifierar i sin empiri fyra idealtypiska företagarkategorier utifrån skilda förhållningssätt till familj och omsorgsarbete å ena sidan och till företagandet och arbete å andra sidan. 


\begin{tabular}{llll}
\hline Tabell 3-1: Domän, betonad aspekt och mål med företagandet & \\
\hline Företagarkategori & Domän i centrum & $\begin{array}{l}\text { Betonad aspekt av } \\
\text { företagandet }\end{array}$ & Mål med företagandet \\
\hline $\begin{array}{l}\text { De familje- } \\
\text { orienterade }\end{array}$ & Familjen, boendet & $\begin{array}{l}\text { Möjlighet att arbeta } \\
\text { hemifrån }\end{array}$ & $\begin{array}{l}\text { Att få vardagen att gå } \\
\text { ihop }\end{array}$ \\
$\begin{array}{l}\text { De genuina } \\
\text { entreprenörerna }\end{array}$ & $\begin{array}{l}\text { Utmaningen, } \\
\text { risktagandet }\end{array}$ & $\begin{array}{l}\text { Projektet, } \\
\text { uppbyggnaden }\end{array}$ & $\begin{array}{l}\text { Realisera nya idéer, } \\
\text { nyskapande }\end{array}$ \\
$\begin{array}{l}\text { De genuina } \\
\text { företagarna }\end{array}$ & Företagandet & $\begin{array}{l}\text { Långsiktighet, } \\
\text { säkerhet, stabilitet }\end{array}$ & $\begin{array}{l}\text { Oberoende, } \\
\text { självbestämmande, } \\
\text { kontroll }\end{array}$ \\
Hobbyföretagarna & Verksamheten & $\begin{array}{l}\text { Underlättar endast } \\
\text { för det egna intresset }\end{array}$ & $\begin{array}{l}\text { Kunna utveckla sig } \\
\text { själv, fä ägna sig åt ett } \\
\text { intresse, leva enligt } \\
\text { ideologisk övertygelse }\end{array}$ \\
& & &
\end{tabular}

Källa: Lönnbring (2003:137)

De familjeorienterade företagarna betonar en integration mellan sitt företagande, sina barn och familj samt den plats de bor på. De genuina entreprenörerna ser företagandet som ett individuellt projekt som är tidsbegränsat; det är uppbyggnaden och att realisera en idé som är det centrala. Det är den grupp som har högst utbildning och som starkast betonar företagandet som en livsstil. De genuina företagarna sätter företagandet i centrum. Det är mindre viktigt vilken verksamhet som bedrivs. Självständighet är framträdande och självbestämmande både uppskattas och eftersträvas. Hobbyföretagarna har ett starkt intresse för det innehållsliga i företagets verksamhet och företagets form är det sätt på vilket man bäst kan utöva detta intresse.

Det är ovanligt att en företagartyp uppträder i sin "rena" form menar Lönnbring (2003). De olika kategorierna griper snarare in i varandra i olika grad. Dessutom skiftar betoningen på olika domäner och kategorier, som framgår av tabell 3-1, över tid beroende på olika förändringar i vardagslivet. Författaren menar vidare att bakom alla dessa varianter av självständigheter finns en vilja till försörjning helt eller delvis och att företagandet i den meningen är en ekonomisk strategi för alla företagande kvinnor.

\section{Landsbygdskontexten}

På landsbygden finns en tradition av ett självständigt sätt att leva (Glesbygdsverket, 2008a). Denna tradition har uppburits främst av jord- och skogsbruken. Strukturella omvandlingar i Sverige har under 1900-talets senare hälft dock inneburit en minskning av antalet jordbruk samt sysselsatta i jord- och skogsbruk och numera är lönearbete landsbygdens dominerande försörjningsstrategi. Forskningen om landsbygden som kontext utgör endast en liten del av forskningen om småföretagande och 
entreprenörskap. Det gäller särskilt forskning med inriktning mot kvinnors företagande.

En tredjedel av Sveriges befolkning bor idag på det som kan betecknas som landsbygd (Företagarna, 2013). Vad som definieras som landsbygd skiljer sig dock mellan olika länder men även mellan olika regioner. Landsbygd i Norrbotten är något helt annat än landsbygd i Skåne. De flesta definitioner bygger på ett motsatsförhållande mellan stad och land. Det är vanligen stad som definieras som begreppet medan landsbygd blir ett restbegrepp. Annorlunda uttryckt blir det rurala det urbanas motsatts. Statistiska Centralbyrån och SKL har sina egna definitioner av vad som är landsbygd 26 där SKLs ger omfattare en glidande skala snarare än ett motsatsförhållande mellan stad och landsbygd. Denna variation i definitioner präglar även forskningen om landsbygd. Westholm (2008) menar att en enhetlig definition skulle fungera som en tvångströja och att det är bättre att var och en som analyserar eller beskriver landsbygden får göra sina egna avgränsningar. En grov uppdelning som kan göras är den mellan stad och landsbygd och det är denna som jag kommer att använda mig av i denna studie. Den baseras på en definition som används av Glesbygdsverket (2008b) där indelningen främst bygger på tillgänglighet. Stad inkluderar det som faller inom ramen för 3000 invånare och uppåt. Landsbygd inkluderar tätort (200-3000 invånare), småort (50-200 invånare), tätortsnära landsbygd (5-45 min till närmaste tätort) och landsbygd (45 min eller mer till närmaste tätort). Utifrån denna uppdelning kan i föreliggande studie 7 av 10 intervjupersoner betecknas som landsbygdföretagare (se bilaga 5).

Andelen företagare på landsbygden i Sverige är relativt sett högre än i stadsregionerna (Bjerke, Johansson, \& Pettersson, 2012). Även förekomsten av enmansföretag och företag med låg omsättning är i jämförelse högre på landsbygden. Kvinnor står för en något lägre andel av företagandet på landsbygden (23\%), jämförbart med i stadsregionerna (26 \%). Resultatet av en enkät som Företagarna (2013) skickade ut till sina medlemmar visade på en större tillväxtvilja bland företagare på landsbygden än bland andra företagare samtidigt som de även upplevde fler hinder för tillväxt. Dessa hinder bestod främst i upplevelserna av externa och strukturella förutsättningar

\footnotetext{
${ }^{26}$ Statistiska Centralbyrån (SCB) avgränsar inte gles- och landsbygd i egentlig mening utan istället avgränsar man tätorter. Definitionen av tätbebyggt område är "alla hussamlingar med minst 200 invånare, såvida avståndet mellan husen normalt icke överstiger 200 meter". Det som blir kvar utanför tätorterna bildar glesbygd (Statistiska Centralbyrån, 2010).

Ett annat exempel på definition av begreppen glesbygd och landsbygd är Sveriges kommuner och landstings definition. De har gjort en indelning av kommunerna i nio grupper efter vissa strukturella egenskaper som bland annat befolkningsstorlek, pendlingsmönster och näringslivsstruktur. Ordet landsbygdskommuner förekommer inte som benämning för någon av grupperna men däremot finns det en grupp som betecknas som glesbygdskommuner, dessa beskrivs som kommuner med en tätortsgrad understigande 70 procent och mindre än åtta invånare per kvadratkilometer (Sveriges Kommuner och Landsting, 2015).
} 
mellan land och stad. Strukturella hinder för företagande på landsbygden angavs bland annat vara glesa marknader på utbuds- och efterfrågesidan. Den nya informationstekniken spås dock vara landsbygdsföretagens väg in i framtiden då den öppnar upp hela världen som marknad (Johannisson, 2008).

Forskningen om företagande på landsbygden är till stor del inriktade mot verksamheter som turism, naturresurser eller livsmedelsproduktion (Waldenström \& Westholm, 2006). En faktor som sägs gynna landsbygdens företagande är att upplevelseekonomins kunder söker avskildhet och särskildhet snarare än likriktning och standardisering. Särskildhet innefattar att som kund bli behandlad på ett personlig och unikt sätt medan avskildhet innefattar att i tid och rum bli frikopplad från sitt vardagsliv. Här erbjuder landsbygden goda möjligheter.

Landsbygden som kontext för företagande i England har studerats av bland andra Jack och Andersson (2002) vilka visar att den lokala inbäddningen influerar hur företagare etablerar och driver sina företag. Etableringen av företag influeras av sociala faktorer såsom familj och livsstil. Genom sin lokalkännedom kan företagarna lättare identifiera och agera på möjligheter för företagande. I en dansk studie av landsbygdskontextens influenser på företagande och skapande av möjligheter visar Korsgaard, Ferguson och Gaddefors (2015) att företagarna mixar sin lokala inbäddning och kännedom om trakten med strategiskt byggda icke-lokala nätverk.

I en studie med ett försörjningsperspektiv som utgångspunkt och företagande som en sysselsättning och livsform intervjuade Hellberg (1990) kvinnor på landsbygden (Orust) med ett begränsat utbud av arbetstillfällen och social omsorg. Fyra kategorier av motiv till att starta eget kunde identifieras bland dessa kvinnor; (1) Sysselsättningsproblem på orten, (2), Familjeskäl (inkluderar en situation där man träffat en man som är företagare eller har startat företag samt som ett sätt att lösa barnpassning), (3) Egenskaper hos det tidigare jobbet, (4) En hobby som utvecklats. Hellberg (1990) menar att samtliga fyra skäl kan föreligga samtidigt, med ett av dem som en utlösande faktor. Vidare identifierades tre tematiska drag i kvinnornas anpassning till den lokala arbetsmarknadens villkor och deras försök att förändra den. För det första anpassade kvinnorna sitt arbetskraftsutbud till sina familjeförhållanden. För det andra skedde en kunskapsutveckling parallellt med kvinnornas yrkesverksamheter. För det tredje handlade det om en flexibilitet vad gällde såväl arbetsuppgifter som arbetstider. Trots den omfattande arbetsbördan uppgav kvinnorna i studien att de upplevde en stor frihet. Trots långa arbetsveckor, att de är uppbundna på kvällar och helger och inte kan ta ut en marknadsmässig semester uppvägdes detta av flexibilitet och en känsla av frihet $i$ arbetet.

Så som jag tidigare nämnt har Lönnbring (2003) undersökt kvinnors liv och företagande på den värmländska landsbygden med utgångspunkt i företagande som 
livsform. Flera av företagen i studien har en koppling till turismsektorn. I empirin ingår bland annat företagare inom café, hotell och restaurang samt vandrarhem och syftet är att förklara och hitta mönster i det kvinnliga företagandet på den värmländska landsbygden. Studien visar att det finns många olika drivkrafter och attityder till företagande bland de intervjuade företagarna. Uppskattningen av företagande som livsstil och medföljande frihet är dock ett gemensamt drag. En slutsats är att även om företagande handlar om självständighet finns det många olika typer av självständighet. Landsbygden som en rumslig kontext lyfts i denna studie fram främst som en faktor som bär med sig traditionella ideal av självständighet och egenkontroll. Kvinnornas företagande ses som medvetna val vad gäller försörjning i ett föränderligt lokalsamhälle.

Hur företagande kan förstås $\mathrm{i}$ form av potentiella förändringar $\mathrm{i}$ hur genus görs diskuterar Pettersson och Heldt Cassel (2014) i en studie av kvinnors företagande på landsbygden. Studien visar att omvandlingen av den traditionella lantgården till olika typer av turistföretagande både förstärker och förändrar hur genus görs. Å ena sidan förstärks det genom att företagandet bygger på en bild av huslighet och landsbygdsromantik där kvinnorna spelar på rollen som traditionell bondmora. $\AA$ andra sidan förändrar de hur genus görs genom att identifiera sig som entreprenörer och genom att de förändrar användningen av lantgården.

\section{Professioners feminisering och könsmärkning}

Genus görs inte enbart i relation till individer utan även till organisationer, professioner och företag (Acker, 1990; Korvajärvi, 1998). Det vill säga, även professioner präglas av en manlig könsmärkning. Som många andra teorier har professionsteori uppmärksammats som genusblind och själva professionsepitetet som präglat av manliga normer och karaktärsdrag (Johansson, 1997). Davies (1996:661) menar att mannen som norm är så genomgående att professionsteorin och begreppet profession uttrycker en könsbias: "(...)a key feature of profession, as presently defined, is that it professes gender".

Allt eftersom kvinnor fått tillgång till universitetsutbildning, detta skedde formellt i Sverige redan 1873 men i större utsträckning först under 1960-talet, har de tidigare manligt dominerade professionerna kommit att präglas av en ökad andel kvinnor (Högskoleverket, 2005). För att beskriva ett ökat inflöde av kvinnor i en profession används ofta beteckningen feminisering. Feminisering av professioner har på olika sätt varit fokus för ett flertal studier, såväl i Sverige som internationellt (se Bolton \& Muzio, 2007; Florin, 1987; Kelleher, 2011; Nordgren, 2000; Riska, 2010). Trenden av feminisering inkluderar professioner såsom läkare (Crompton \& Lyonette, 2011), 
jurister (Kay \& Gorman, 2008), revisorer (Dambrin \& Lambert, 2008; Jonnergård \& Stafsudd, 2009), lärare (San Román \& Cortina, 2006) och som vi sett i synnerhet veterinärer (Irvine \& Vermilya, 2010).

Feminisering kan indikera en ökning av kvinnor i jämförelse med män, i absoluta tal eller proportionerligt. Det kan även avse att en feminin (omvårdande) kultur dominerar inom professionen (Kelleher, 2011). Som exempel på detta kan vi ta läkarprofessionen där det tidigare låg en betoning på ett systematiskt tankesätt med grund i den medicinska vetenskapen. Detta sätt att tänka ansågs vara en manlig egenskap. Kvinnor ansågs kunna arbeta inom vården men då med uppgifter som passade den stereotypa bilden av kvinnor - såsom omsorg och vårdande uppgifter (Greiff, 2006). Att på detta sätt se omvårdnad och känslomässigt arbete som indikatorer på en feminin/feminiserad profession är vanligt $i$ forskning om professioner och bygger på stereotypa antaganden om vad som är manligt respektive kvinnligt (Svensson \& Evetts, 2010). Ett sätt att komma bort från otydlighet är att använda begreppet numerär feminisering för att poängtera att det är antal/andel det handlar om och inget annat (Bolton \& Muzio, 2008). Jag väljer i denna avhandling att använda mig av uttrycket numerär feminisering som en indikation på en förändring av könssammansättningen gällande antal/andel i en profession.

En organisation som domineras av kvinnor behöver dock inte nödvändigtvis präglas av en kvinnlig könsmärkning (Acker, 1990; Britton, 2000). På ett liknande sätt finner Irvine och Vermilya (2010) i en studie av veterinärprofessionen i USA att den numerärt feminiserade professionen fortfarande bär med sig maskulina konnotationer. Som kontrast till detta menar Greiff (2006) att skiften i könssammansättning ofta går hand i hand med att professionens könsmärkning förändras. Författaren menar att processerna blir ömsesidigt förstärkande. Enighet finns dock mellan forskarna i att det i grunden finns en rad föreställningar om vad som är kvinnligt respektive manligt.

Den förändring i form av den numerära feminisering som har skett i flera professioner lägger grunden för två motsatta utvecklingstendenser menar Hellberg (1989). Den numerära feminiseringen indikerar dels en könsutjämning inom flera av de tidigare manligt dominerade professionerna och dels en utveckling mot könspolarisering där vissa professioner blir feminiserade medan andra kvarstår som manliga. Greiff (2006) menar att historien tyder på att en professions könssammansättning inte förändras från dominans av ett kön till en jämn könsfördelning. Snarare blottläggs ett mönster där professionen går från ytterlighet till ytterlighet, från att domineras av ett kön till att domineras av ett annat.

En tes är att konsekvensen av en förändring av könsammansättning från män i majoritet till kvinnor i majoritet skulle föra med sig en risk för avprofessionalisering (Einarsdóttir, 1997; Nordgren, 2000). Enligt denna tes ses inträdet av kvinnor i en 
profession som ett problem, medförande urholkning eller degradering/devalvering. Grunden för ett sådant samband bestrids dock av flera forskare (Bolton \& Muzio, 2008; Nordgren, 2000; Silius, 1989). Läkare och veterinär är exempel på numerärt feminiserade professioner vars status alltjämt är hög. Ulfsdotter Eriksson (2006) menar att en förklaring kan vara att en ökad kvinnlig närvaro har mindre betydelse i starkt professionaliserade yrken. Professionsstarka yrkesgrupper bevakar ständigt den egna yrkeskårens ställning i samhället och strider för att behålla en högt värderad position oavsett vem som utgör den huvudsakliga utövaren.

I och med denna, åtminstone numerära, feminisering av flertalet priviligierade professioner har uppmärksamheten i forskningen om professioner skiftat från kvinnors exkludering till kvinnors inkludering. Utvecklingen med ett inflöde av kvinnor har lyft frågan om detta fenomen kan ha en effekt på genussystemet i positiv bemärkelse (Bottero, 1992; Davies, 1996). Mestadels har dock slutsatserna varit pessimistiska, som redan indikerats ovan. Forskare menar att den gamla strategin av kvinnors exkludering från professionerna har bytts mot en strategi av inkludering; emellertid utifrån sämre villkor och $\mathrm{i}$ form av både intern segregering och exploatering (Bolton \& Muzio, 2007; Walby, 1986). I en studie av bland annat jurister och lärare i Storbritannien visar Bolton och Muzio (2008) att det finns en generell tendens av genusprocesser där kvinnor och deras arbete marginaliseras, nedvärderas och exploateras. Det finns från professionens sida ett behov av kvinnornas arbetskraft men de inkluderas aldrig till fullo i professionen. Denna forskning har till viss del kritiserats för att den tar utgångspunkt i genusstrukturer och att sökande efter dessa strukturers överföring gör att man missar processernas komplexitet och därmed aspekter av förändring (Bottero, 1992). Det vill säga att det är genussystemets stabilitet som synliggörs och lyfts fram snarare än variationer och förändring av detsamma.

\section{Strategier mellan och inom professioner}

Det finns en tradition inom professionsforskningen att fokusera på hur professioner utövar stängningar gentemot angränsande grupper för att upprätta och bibehålla kunskaps- och professionsmonopol (Abbott, 1988). Med stängning avses gränsdragning i syfte att exkludera andra professioner och yrkesgrupper från ett visst arbetsområde. Öppningsstrategier används å andra sidan när professioner försöker att utvidga sina arbetsområden genom att söka nya nischer (Agevall \& Jonnergård, 2010). Stängningsstrategier och öppningsstrategier är därmed sammankopplade och förutsättningar för varandra (Ashcraft, Muhr, Rennstam, \& Sullivan, 2012). I en utveckling av en modell av strategier för stängningar (jmf Kreckel, 1980; Murphy, 1984, 1986; Parkin, 1974, 1979) anlägger Witz $(1988,1992)$ ett genusperspektiv på profession. 
I: Uteslutande strategi

Dominant grupp

Underordnad grupp

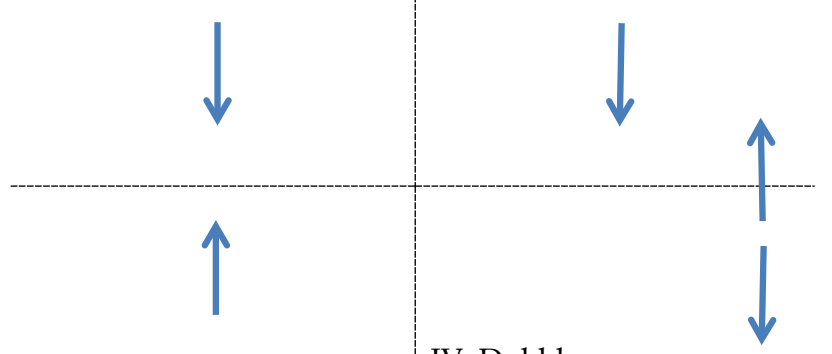

II: Inneslutande strategi
IV: Dubbla

III: Avgränsande strategi

stängningsstrategier
Inkräktarstrategi

Uteslutningsstrategi

\section{Figur 3-3: Strategier för stängningar. (Witz, 1992:45)}

Kommentar: Figuren illustrerar strategier för stängningar mellan professioner samt, $i$ utvecklingen mot genusstrategier, mellan mäns och kvinnors professioner/yrkesgrupper. Begreppsapparaten är översatt från engelska till svenska (jmf Winston Castro, 1992). Nedåtgående pilar indikerar maktutövning från dominant grupp. Uppåtgående pilar indikerar motverkande maktutövning från underordnad grupp.

Med uteslutande strategier (I) avses att en dominant grupp försöker utesluta en underordnad grupp genom att neka tillträde till en profession (Witz, 1992). Detta sker exempelvis på basis av krav på en särskild utbildning samt legitimation. Könade ${ }^{27}$ former av uteslutande strategier har använts för att säkra mäns tillgång till belöningar och möjligheter inom en profession. Som en motreaktion använder sig den underordnade gruppen av inneslutande strategier (II) i ett försök att vinna tillträde till den grupp som man exkluderas från (Witz, 1992). Könade former av inneslutande strategier innebär att kvinnor försöker motverka det nekade tillträdet på grund av sitt kön med argument för inneslutning baserade på okönade individualistiska kriterier som färdigheter och meriter.

Avgränsande strategier (III) tillämpas som ett sätt att kontrollera närliggande grupper när det gäller arbetsdelning. Könade avgränsande strategier används för att ringa in

\footnotetext{
27 Witz använder sig av begreppet "gendered". Jag har här valt att översätta detta till könade på svenska. Ett alternativt uttryck skulle vara genusifierade (jmf Thurén, 1996). Könade ger dock ett mindre otympligt intryck anser jag.
} 
kvinnor inom en relaterad men distinkt sfär av kompetens som kan underordnas mansdominerade professioner. Här är ett klassiskt exempel läkare och barnmorskor. Den dominanta gruppen, i detta fall läkarna, har makten att övervaka och reglera barnmorskornas arbete.

Motreaktionen till avgränsande strategier tar sig uttryck i form av dubbla stängningsstrategier (IV). Såsom begreppet antyder används två olika strategier; Inkräktarstrategier samt uteslutningsstrategier. Dessa strategier inkluderar motstånd mot avgränsningen ifråga (inkräktarstrategier) men även försök att konsolidera den egna positionen inom en profession genom att använda uteslutande strategier. Könade former av dubbla stängningsstrategier involverar en utövning av makt på två håll och beskriver hur kvinnorna dels bestrider mäns avgränsningar men även arbetar för att utesluta män från den egna gruppen.

Även denna modell, menar jag, kan kritiseras för att inte lämna utrymme för aktörerna och deras möjligheter att handla annorlunda (jmf Giddens, 1984). På detta sätt synliggörs inte möjligheter till förändring utan enbart stabilitet. Dessutom förstärker uppdelningen av dominanta och underordnade grupper ytterligare dikotoma förställningar om män och kvinnor. Som vi ska se fortsatt kan även kvinnor vara del i processer av uteslutning och avgränsning av andra kvinnor (jmf Bird \& Rhoton, 2011; Irvine \& Vermilya, 2010). Det är därför viktigt att differentiera mellan dominanta och underordnade grupper på andra grunder än enbart kön, såsom exempelvis ålder, etnicitet eller erfarenhet.

Då professioner styrs genom gemensam kunskap, förståelse och normer blir dessa centrala för den professionella verksamheten (Jonnergård \& Stafsudd, 2009). Inom revisorsprofessionen visar Jonnergård och Stafsudd (2009) hur både kvinnor och män tillskrivs genusstereotypa egenskaper inom professionen. Einarsdottir (1997) förklarar olikheter och könssegregering med hjälp av stängningsteori. Författaren menar att på grund av den ständigt pågående specialiseringen och utvidgningen av kunskap blir den interna trängseln inom professionen allt större och därmed vänds strategierna inåt exempelvis för att dra avgränsande linjer mellan olika fält. Det är främst på detta sätt som jag i denna avhandling kommer att nyttja stängningsteorins begreppsapparat.

Einarsdottir (1999) visar i en studie av den svenska läkarprofessionen att den interna segregeringen är nära knuten till olika specialiseringars status inom professionen. Män är överrepresenterade inom specialiteter med hög status medan kvinnor i högre grad finns representerade inom specialiteter med låg status. Kirurgi är ett exempel på en specialisering med hög status som är mansdominerad. En slutsats av studien är att genus och status är delvis sammanvävda och ömsesidigt förstärkande. Dessa processer menar Einarsdottir är en betydande del av de utestängande mekanismer som upprätthåller könssegregeringen inom läkarprofessionen. 
Veterinärprofessionen har fått tjäna som exempel i en amerikansk studie som fokuserar på en numerärt feminiserad profession med en maskulin kultur (Irvine \& Vermilya, 2010). Mot denna bakgrund har undersökts hur maskulint märkta normer kring arbete och identitet bibehålls trots inflödet av kvinnor i professionen. Studiens fokus ligger på diskurser och resultatet visar att de diskursiva strategier som de kvinnliga veterinärerna använder sig av bidrar till att upprätthålla den maskulina normen. Särskilt två diskursiva strategier lyfts fram; kvinnor som stereotypiserar andra kvinnor samt kvinnor som tar avstånd från det feminina och istället gör maskulinitet (Irvine \& Vermilya, 2010).

Vad gäller stereotypisering av andra kvinnor ger Irvine \& Vermilya (2010) exempel på hur de kvinnliga veterinärerna talar om kvinnor som grupp som vårdande/moderliga och att det är detta som lockat dem till veterinärprofessionen. Efter att ha erhållit veterinärlegitimationen begränsar dock dessa vårdande roller kvinnornas karriärer, då exempelvis familjeansvar lyfts fram som en förklaring till de begränsade karriärmöjligheterna. Samma diskurser som män under lång tid använde för att hålla kvinnor utanför professionen används nu istället för att förklara kvinnornas begränsade rörlighet inom professionen, och det är kvinnorna själva som tillämpar dem konstaterar Irvine och Vermilya (2010). När de intervjuade kvinnorna ska utgå ifrån sig själva i sammanhanget, snarare än tala om kvinnor generellt, uppstår en diskurs där de argumenterar för sina egna framgångar som ett resultat av att de exempelvis har intresse av vetenskap snarare än omvårdnad, har maskulina karaktäristiska (inte tvekar att kräva högre lön etc.) samt framhäver sig som en typisk pojk-flicka.

Paralleller kan dras mellan Irvine och Vermilyas (2010) studie och den studie där Bird och Rhoton (2011) presenterar en genomgång av forskning med fokus på personliga strategier som kvinnor i mansdominerade professioner utvecklar och nyttjar för att främja sin karriär. Fokus är här hur olika strategier påverkar kvinnornas kollektiva försök att bli rättvist behandlade när det gäller att få ta del av möjligheter och belöningar. Ur ett socialkonstruktionistiskt perspektiv argumenterar författarna för att strategier är något som nyttjas då aktörer måste hantera strukturerna. Kvinnor använder strategier för att försöka bringa klarhet i diskrepansen mellan deras egna värderingar i relation till deras faktiska omständigheter. Strategierna skiljer sig mellan olika individer. Sex stycken primära teman för strategier räknas upp av författarna; Vara en av grabbarna (1), Spela på feminitet (2), Hävda neutralitet (3), Beteckna som politik (4), Multipla strategier (5) samt Utmana könade organisationer (6).

Vid tillämpningen av "vara en av grabbarna" (1) anpassar sig kvinnorna till ett sätt att vara som de kopplar samman med den, inom professionen, rådande maskuliniteten. Konsekvensen av strategin blir dock att kvinnorna ofta betraktas som ofeminina och riskerar marginalisering. "Spela på feminitet" (2) innebär att kvinnorna genom att visa 
sig som feminina söker tillhörighet baserat på stereotypa förväntningar, exempelvis genom att flirta med chefen. I längden kan denna strategi underminera kvinnornas egna men även andra kvinnors legitimitet och möjligheter till att avancera i organisationen. Genom att "hävda neutralitet" (3) antar kvinnorna en linje av att själva vara neutrala i sitt agerande samt tillbakavisar andras försök att påvisa genuspraktiker. Problemen med denna strategi blir att hålla fast $\mathrm{i}$ den trots att det uppstår motstridiga situationer. Strategin "beteckna som politik" (4) kan relateras till "hävda neutralitet" och innebär ett avståndstagande från kvotering, program för genusmedvetenhet etc. i organisationen. En konsekvens blir att de kvinnor som hänfaller åt denna strategi hjälper till att bibehålla könsbarriärer i organisationen. "Multipla strategier" (5), det vill säga en blandning av de ovan nämnda strategierna används i olika stadier av kvinnornas professionella karriärer men även i livet generellt. Att vara en av grabbarna är en strategi som ofta revideras när en kvinna blir gravid exempelvis. Slutligen finns även strategin där kvinnorna bestämmer sig att utmana den könade organisationen (6), denna strategi är dock enligt författarna mindre vanlig än de övriga.

I en svensk studie där två empiriskt grundade material jämförs lyfts och problematiseras genusskapande processer bland läkare samt familjerättssekreterare (Eriksson \& Eriksson, 2002). Med "doing gender" perspektiv studeras hur genus görs i informanternas egna berättelser. Resultatet visar att även om informanterna talar om två olika sammanhang förhåller de sig i sina berättelser om sin vardag till vissa gemensamma konstruktioner vad gäller kön och profession. Noterbart här är att både män och kvinnor reproducerar manlig överordning och en manligt könsmärkt profession. Författarna menar att det är möjligt att tala om kön både i termer av stabilitet och förändring även om deras studie huvudsakligen ger exempel på stabilitet. "(...)det pågår ett förändringsarbete. Frågan är dock vilket utrymme det finns för alternativa och föränderliga könskonstruktioner i informanternas konkreta vardag, där alternativa och föränderliga (köns)konstruktioner görs till något annat än kön - till exempel till individuell personlighet eller professionalitet - och 'kön' förblir stabilt olikt (Eriksson \& Eriksson, 2002:66)."

\section{I skärningspunkten mellan småföretagande, profession och genus}

Den forskning som kombinerar småföretagande, profession och genus är begränsad och i flertalet studier ligger analysnivån på individen och dennes identitet. Då denna avhandling inte lägger fokus på identitet ges här endast ett par exempel på dylika studier med avsikt att ge kännedom om denna del av forskningsfältet. 
I en studie av kvinnliga lärare som gått från kommunal anställning till att starta egna friskolor lägger Lindgren (2000) fokus på identitetsskapande. Frågan hon ställer sig är vilken betydelse profession respektive företagande har för kvinnornas identitetsskapande. En slutsats författaren drar är att "såväl profession som entreprenörskap är könat och samtidigt integrerat; genom att professionen är könad blir också entreprenörskapet negligerat" (Lindgren, 2000:132). Frågan Kovalainen och Österberg-Högstedt (2013) ställer sig är huruvida en professionell identitet och företagaridentitet kan separeras och om det ens är meningsfullt? Med utgångspunkt i professioner inriktade mot socialt arbete samt hälso-och sjukvård visar författarna att även om professionen utgör kärnan för företagandet så uppstår starka spänningar i identitetskonstruktionen där profession och företagande men även genus möts. En slutsats såväl Lindgren (2000) samt Kovalainen och Österberg-Högstedt (2013) landar i är att kombinationen av profession, företagande och genus innebär en komplex process av identitetsskapande. Andra som kombinerat profession, företagande och genus med identitet är Hytti (2005) samt Gustavsson och Rönnqvist (2004). De sistnämnda, som har jämfört företagande i en kvinno- respektive en mansdominerad bransch, menar att yrkesutövningen kan bli en så stark drivkraft att företagandet blir ett hinder för individen.

Lindgren (2002) tar ett vidgat grepp på sin empiri från ovanstående studie då hon diskuterar kvinnliga lärare i samband med begreppet livsform. Författaren menar att de flesta av kvinnorna som startat friskolor drivs av sitt pedagogiska engagemang snarare än av lusten att driva företag. Har då kvinnor någon fördel av sin professionsstatus vad gäller företagande? I en svensk studie av företagarpar (med en jämförelse av advokater samt ICA-handlare) kommer Javefors Grauers (2002) fram till att professionen $\mathrm{i}$ de kvinnliga advokaternas fall, bidrog till att modifiera genussystemets uttryck. Författaren menar att de kvinnliga advokaterna synliggjordes och gynnades av att ha beviljats inträde i advokatsamfundet då de blev dubbelt synliga - såsom företagare och legitimerade advokater. Studien visade dock även på traditionella genusmönster av manlig överordning och kvinnlig underordning exempelvis vad gäller arbetsdelning. Här indikeras således mönster av både stabilitet och förändring. Marlow och Carter (2004) menar å andra sidan att underläget består även i kontexten av en profession (i detta fall med utgångspunkt i Storbritannien och revisorsprofessionen).

I de fall då företagande, genus och veterinärprofessionen specifikt har kombinerats i forskning ligger fokus på entreprenörskapsutbildningar för veterinärer och skillnader i inkomster av företagande mellan manliga och kvinnliga veterinärer samt vidhängande förklaringar till detta (Cron, Bruton, \& Slocum Jr., 2006; Henry \& Treanor, 2010, 2012a; Mueller, 2007). Henry och Treanor (2010, 2012a) argumenterar för införandet av kurser i företagande inom veterinärutbildningen då de menar att 
företagande är något som tillhör vanligheterna i veterinärprofessionen. I en kvantitativ och jämförande studie av amerikanska företagande veterinärer visar Cron, Bruton och Slocum Jr (2006) att kvinnor tjänar märkbart mindre än män och att detta kan härledas till faktorer såsom att de har mindre erfarenhet som företagare men även av att vara chef samt att det finns skillnader i drivkraften till företagandet; där männens fokus främst var inkomst. I en amerikansk enkätstudie av veterinärer, skriver Mueller (2007) att män visade mindre empati gentemot sina klienter och var mer benägna att sätta tanke för känsla vid beslutsfattande. Samtidigt visade resultatet att de män som visade empati hade högre inkomst än de som inte visade empati. Detta mönster stod inte att finna bland kvinnor (Mueller, 2007). I en konferensartikel presenterades helt nyligen en studie om villkoren för kvinnor som är veterinärer och företagare i Storbritannien (Treanor \& Marlow, 2016). Författarna konstaterar att veterinärprofessionens feminisering, i likhet med flera andra professioner, inte utmanar professionens manliga könsmärkning utan att denna snarare reproduceras. Segregeringen reproduceras även i förtagandet. En trend mot större praktiker och kedjor i veterinärbranschen minskar möjligheten för småföretagande i professionen. Treanor och Marlow (2016) menar att framtida generation av kvinnor som tar examen kommer få svårt med finansiering för att starta veterinärpraktiker då det pågår en ökning av stora koncerner och kedjor i branschen som intensifierar konkurrensen.

\section{Sammanfattning}

I det här kapitlet har jag definierat studiens nyckelbegrepp i förhållande till de tre forskningsfälten småföretagande, profession och genus.

Småföretagande är i fokus i denna avhandling men då forskningen om småföretagande och entreprenörskap är delvis överlappande kommer jag även att inkludera teorier om entreprenörskap där dessa är tillämpbara. Det huvudsakliga intresset ligger vidare på processer snarare än egenskaper.

Jag använder mig av både kön och genus som begrepp med åtskillnaden att kön är kopplat till biologi (man/kvinna) medan genus refererar till det som är socialt och kulturellt konstruerat (manligt/kvinnligt). Genussystemet är ett sätt att beskriva och belysa maktrelationer mellan könen på en strukturell nivå (Hirdman, 1988). Att genus är något som görs är en teoretisk utgångspunkt som kan samlas under beteckningen "Doing gender"(West \& Zimmerman, 1987). Att kombinera en "doing gender" ansats med genussystemets principer av hierarkisering och segregering ser jag som ett fruktbart sätt att studera pendlingen mellan struktur och aktör. Det öppnar upp för att se såväl stabilitet och förändring i form av glipor i systemets mönster (jmf Fogelberg Eriksson, 2005). 
Det förekommer en rad olika definitioner och klassificeringar av vad som utgör en profession. Begreppet avser bland annat en yrkesmässig organisering av arbete och innefattar kriterier såsom kunskapsmonopol och autonomi (Molander \& Terum, 2008). Professioner är sett till karaktäristika heterogena snarare än homogena. Fokus i denna avhandling ligger främst på profession som kontext.

Kvinnors företagande ges ökad uppmärksamhet inom forskningen men i relation till vad som skrivs inom ramen för småföretagande- och entreprenörskapsforskningen utgör det fortfarande en liten del. Fokus för denna forskning har förskjutits från studier av företagandet till studier av diskurser i media och policydokument. Liksom Barley och Kunda (2001) förespråkade en återgång till att studera det konkreta arbetets organisering vill jag i denna studie återgå till att studera företagarens vardag som den beskrivs av företagaren själv.

Det har sedan länge uppmärksammats att företagandet och entreprenörskap är inbäddat i sin kontext, på ett sätt som har stor betydelse för hur företagandet bedrivs. En professions kontroll över kunskap och arbetsuppgifter ger goda förutsättningar för företagande. Flera professioner har en tradition av företagande, trots detta är forskningen om företagande och profession begränsad. Livsformsteori tar utgångspunkt i att människor på grund av olika villkor har varierande sätt att hantera och leva sina liv samt fatta beslut. I livsformsteorin har företagande främst kopplats samman med självständighetens livsform och i fråga om kvinnors företagande har flera olika företagarkategorier utvecklats. Livsformsteori har även satts i relation till företagande på landsbygden. På landsbygden finns en tradition av ett självständigt sätt att leva (Glesbygdsverket, 2008a). Denna tradition har uppburits främst av jordoch skogsbruken. Landsbygden är i denna studie en rumslig kontext att ta hänsyn till då 7 av 10 intervjupersoners företag är lokaliserade på landsbygden.

Flera av de traditionella professionerna präglas av en manlig könsmärkning. Denna könsmärkning tar sig även uttryck inom professioner i form av en intern segregering. Den interna segregering kan ses som del i de stängningsstrategier som professioner nyttjar för att gentemot angränsande grupper upprätthålla och bibehålla kunskapsoch professionsmonopol. Det är främst på detta sätt som jag i denna avhandling kommer att nyttja stängningsteorins begreppsapparat (det vill säga inom en profession samt ur genusperspektiv).

Den forskning som kombinerar småföretagande, profession, och genus är begränsad. Flera studier har fokuserat på företagarens identitet. Andra har diskuterat hur professionsstatusen påverkar kvinnors underordning. I en svensk studie av företagarpar (med en jämförelse av advokater samt ICA-handlare) kommer Javefors Grauers (2002) fram till att professionen i de kvinnliga advokaternas fall bidrog till att modifiera genussystemets uttryck. Marlow och Carter (2004) menar å andra sidan att 
Kapitel 3: Teoretisk referensram

underläget består även i kontexten av en profession (i detta fall med utgångspunkt i Storbritannien och revisorsprofessionen). 


\section{Kapitel 4}

\section{Metod}

I

detta kapitel kommer de metodologiska val som har varit aktuella under avhandlingsarbetet att beskrivas och motiveras. Inledningsvis redogörs för några utgångspunkter för studien. Därefter berättas kort om bakgrunden till studien för att redogöra för min förförståelse. Vidare redogörs för forskningsprocessen $\mathrm{i}$ form av undersökningsmetoder, urval, genomförande och analys. Slutligen diskuteras även kvalitetskriterier och etik i relation till de metoder som använts.

\section{Forskningsansats}

I denna avhandling studeras kvinnors företagande i en profession stadd i förändring. Strävan har varit att skapa förståelse och att synliggöra komplexitet i samspelet mellan företagande, profession och genus. Denna strävan ställer krav på metoder som till sin ansats är tolkande och som ger möjligheter att blottlägga mångfald, detaljer och variationer i det studerade fenomenet. Det gör jag genom att be människor som kan ge en vardaglig bild av vad det innebär att verka i denna skärningspunkt att berätta om sina erfarenheter av att vara kvinnor och företagare i ett yrke statt $\mathrm{i}$ förändring, nämligen veterinärer.

Genus ses i denna studie som en dynamisk och framväxande social konstruktion. Den teoretiska ansatsen "doing gender" tar utgångspunkt i att genus är något som skapas ständigt och rutinmässigt i vardagen i interaktioner mellan människor och i relation till en viss kontext (West \& Zimmerman, 1987). Forskningsfrågor som handlar om hur genus görs lämpar sig därmed väl att studera med en kvalitativ ansats. Den huvudsakliga källan till empiri har varit intervjuer med företagare som är kvinnor och veterinärer. Som beskrivs nedan har intervjuerna kombinerats med bl.a. 
dokumentstudier om professionens utveckling i syfte att generera underlag för en rik framställning. Processen har präglats av en växelverkan mellan teori och empiri.

Ytterligare en utgångspunkt för metodvalet är ett förhållningssätt där både struktur och aktör inkluderas. Inspirerad av Giddens (1984) ser jag struktur oh aktör som förbundna med varandra på så sätt att de utgör två sidor av samma mynt. Människor såsom aktörer reflekterar över både sina egna och andras handlingar. Det centrala för min syn på detta är att aktören är kapabel att handla samt $i$ varje läge hade kunnat handla annorlunda. Det finns med andra ord ett visst handlingsutrymme. Samtidigt finns det i strukturerna regler för handlandet som ger det en mening, sanktionerar det likväl som begränsar det. Reglerna tar sig uttryck i form av förgivettagna sätt för hur man ska bete sig i olika situationer. Struktur och aktör är på så sätt tätt sammantvinnade samtidigt som strukturer är såväl möjlighetsskapande för handlingar som begränsande för vilka handlingar som aktören kan utföra (jmf Giddens, 1984). Denna utgångspunkt ligger till grund för valet att kombinera det aktörsorienterade "doing gender" med det strukturorienterade genussystemsynsättet.

\section{Bakgrund och förförståelse}

Den vanligaste frågan jag brukar få efter att jag har berättat om min studie är "varför blev du intresserad av veterinärprofessionen?". I början av min doktorandanställning (mer exakt i november 2009) deltog jag i en programkonferens i Jönköping. Konferensen genomfördes som del i Vinnovaprojektet "Kvinnors företagande" där mina handledare ansvarade för delprojektet "Kvinnors företagande i spåren av den offentliga sektorns omvandling". Projektet avrapporterades i sin helhet till Vinnova under 2012 och min licentiatavhandling "Det självklara företagandet?" var en del av detta.

Vid en av sessionerna deltog tre praktiker som berättade om sina företag. Vid sidan av en väskaffär och ett företag med inriktning mot ytbehandling av plåt fanns en representant från ett kooperativ av kvinnor som drev ett veterinärsjukhus. Denna veterinär fångade mig med sin berättelse om sitt företag. Hon berättade om den huvudsakliga inriktningen mot sällskapsdjur och om hur företaget dubblat sin omsättning under loppet av 6 år. I en personalgrupp på 45 individer fanns det en man - han arbetade dock deltid. Kooperativet bestod i sin tur av sex kvinnor varav två veterinärer och fyra sjuksköterskor. I egenskap av hundägare hade jag viss kunskap om veterinärers arbetssituation och denna kvinnas berättelse gjorde det tydligt för mig att det fanns många intressanta frågetecken som kunde vara värda att söka räta ut. Hur var det egentligen med könssegregering och normer inom professionen? Hur hade professionen växt fram och utvecklats? Hur passade de offentligt finansierade 
distriktsveterinärerna in i det hela? Det jag fann var ett intressant exempel på en profession i förändring där de teoretiska fälten av småföretagande, profession och genus möts.

I min licentiatavhandling om kvinnors företagande i veterinärprofessionen visade jag att kombinationen av att ha en professionstillhörighet samt att vara företagare leder till en rad dilemman där individen ställs mellan aspekter av etik och lönsamhet, kund och patient samt kollega och konkurrent (Appelkvist, 2013). I samband med dessa dilemman diskuterade jag även att genussystemet var en viktig push-faktor ifråga om att ta steget att bli företagare. Där kunde historien ha slutat men jag var inte redo att lägga kvinnors företagande i veterinärprofessionen åt sidan. Jag såg ytterligare behov av att utveckla och utmana synen på kvinnors företagande. Därför valde jag att göra en fördjupad analys med utgångspunkt $i$ det empiriska material som användes $i$ licentiatavhandlingen men utifrån en annan forskningsfråga och med en fördjupad analys ur ett nytt perspektiv. Jag valde att gå vidare med ämnet kvinnors företagande i veterinärprofessionen och lägger här fokus på det komplexa samspelet mellan företagande och profession samt hur genus görs.

$\mathrm{Jag}^{28}$ vill även ge läsaren en bakgrund till mig som person. Jag menar, i likhet med Harding (1987), att det är viktigt att placera forskaren inom ramen för den tavla som hen söker att måla. Därmed kommer jag nedan att kort berätta om mig och mina kopplingar till denna studie. Jag har en erfarenhet av att möta veterinärer då jag är uppvuxen med hund samt numera själv är hundägare. Jag har mött veterinärer i egenskap av djurägare och kund ett flertal gånger. Jag har suttit i väntrummen, talat med veterinärer om ordinationer och varit med vid avlivningen av en älskad hund. Innebörden av allt detta är att jag har ett visst intresse för djur, särskilt hundar, och att jag ser djur som betydelsefulla varelser. Det betyder även att jag har erfarenheter av att möta och samtala med veterinärer i deras arbetsmiljö. Min anknytning till djur har varit mig behjälpligt under denna studies gång, inte minst i samtalen med intervjupersonerna då det har fungerat som ett sätt att skapa gemenskap och en god kontakt. Under tiden som forskarstuderande har jag, vid sidan av den tidsperiod som det empiriska materialet samlades in, haft insikt i veterinärsektorn i det aktuella länet via media men även via personliga erfarenheter. Jag har även till viss del följt professionens utveckling i media nationellt. Jag var dock varken före eller under studiens genomförande har varit kund hos någon av de veterinärer jag har intervjuat.

\footnotetext{
${ }^{28}$ Detta stycke innehåller delvis text från min licentiatavhandling (Appelkvist, 2013:35).
} 


\section{Forskningsprocess och undersökningsmetoder}

Under forskningsprocessen har jag pendlat mellan att fokusera på empiri respektive teori. Även om forskningsprocessens delar så som de beskrivs nedan ger intryck av ett linjärt flöde så har arbetet i praktiken inneburit ett pendlande fram och tillbaka mellan de olika delarna. Nedan (tabell 4-1) åskådliggöras forskningsprocessen i form av en tidslinje, där växelverkan mellan teori och empiri illustreras.

\begin{tabular}{|c|c|c|c|c|}
\hline Årtal & & Forskningsprocess, aktivitet & Teori & Empiri \\
\hline \multirow[t]{2}{*}{2010} & VT & Dokumentstudie samt orienterande intervjuer. & & $\mathrm{X}$ \\
\hline & HT & Kartläggning samt teoristudier & $X$ & $X$ \\
\hline \multirow[t]{2}{*}{2011} & VT & Intervjuer, Orienterande dokumentstudie fördjupning & & $X$ \\
\hline & HT & Intervjuer, Orienterande dokumentstudie fördjupning & & $x$ \\
\hline \multirow[t]{2}{*}{2012} & VT & $\begin{array}{l}\text { Teoristudier fördjupning. Analys - växelverkan } \\
\text { mellan teori och empiri. }\end{array}$ & $x$ & \\
\hline & HT & Analys - växelverkan mellan teori och empiri. & $x$ & $x$ \\
\hline \multirow[t]{3}{*}{2013} & VT & Framläggning av licentiatavhandling & & $Y$ \\
\hline & & Dokumentstudie: Svensk veterinärtidning & & \\
\hline & $\mathrm{HT}$ & Teoristudier & $X$ & \\
\hline \multirow[t]{2}{*}{2014} & VT & Kompletterande systematisk litteratursökning & $X$ & \\
\hline & HT & Fördjupning i teori & $x$ & \\
\hline \multirow[t]{2}{*}{2015} & VT & $\begin{array}{l}\text { Fortsatt fördjupning i teori. Återgång till } \\
\text { intervjumaterialet - ny tolkning }\end{array}$ & $X$ & $X$ \\
\hline & HT & $\begin{array}{l}\text { Återgång till intervjumaterialet - ny tolkning. Analys } \\
\text { - växelverkan mellan teori och empiri }\end{array}$ & $\mathrm{X}$ & $X$ \\
\hline 2016 & VT & Analys - växelverkan mellan teori och empiri & $X$ & $x$ \\
\hline
\end{tabular}

\section{Dokumentstudier}

Att ${ }^{29}$ bekanta sig med forskningsområdets organisatoriska och historiska kontext rekommenderas av Saunders, Lewis och Thornhill (2007) som ett sätt att möjliggöra samtal med intervjupersoner på ett initierat sätt. Därför har jag gått igenom officiella

\footnotetext{
${ }^{29}$ Innehållet under denna rubrik är helt eller delvis text från min licentiatavhandling (Appelkvist, 2013: 37-38)
} 
dokument, organisationsdokument samt tidningsartiklar, det vill säga genomfört dokumentstudier (Andersen, 1994) på det sätt som beskrivs nedan.

Då veterinärprofessionens organisation till stor del var obekant för mig vid studiens början var en första hållpunkt i forskningsprocessen att läsa in mig på ämnet. Detta skedde huvudsakligen under våren 2010 men är något som jag har återkommit till flera gånger under studiens gång. Information av olika slag har tagits fram och kombinerats i syfte att ge en nyanserad bakgrund till studien, så som officiella dokument (SOU-rapporter, regeringspropositioner etc.), organisationsdokument (i huvudsak från Jordbruksverket och Svenska Veterinärförbundet), offentlig statistik (SCB:s databas), massmedia (tidningsartiklar). En mer detaljerad förteckning över detta material står att finna i bilaga 3.

Med hjälp av Jordbruksverkets och Veterinärförbundets hemsidor kunde jag bland annat navigera mig vidare till relevanta SOU-rapporter på området. Veterinärförbundets jubileumsböcker gav utöver detta en god historisk bakgrund till professionens utveckling. Parallellt med denna inläsning genomförde jag två orienterande intervjuer. En telefonintervju genomfördes med chefen för distriktsveterinärsorganisationens (DVO) huvudkontor för att få svar på frågor som uppkommit. En länsveterinär i Östergötland intervjuade jag samtidigt som jag följde med denne på en karantäninspektion. Mötet syftade till att få en närmare inblick i länsstyrelsens roll i veterinärsektorn. Vidare kunde jag med hjälp av Statistiska centralbyråns databaser samt statistiska årsböcker skapa longitudinella diagram över veterinärsektorns utveckling vad gällde könsfördelning inom utbildningen, antal veterinärkliniker samt deras nettoomsättning.

Vad gäller massmedia användes artikeldatabasen Retriever för en sökning på nyhetsartiklar om DVOs förändring. Sökningen gjordes med ordet veterinär* (trunkering för att få med samtliga böjningar och varianter) och urvalet begränsades till år 1995, dvs. året för distriktsveterinärorganisationens stora omvandling. Resultatet av sökningen blev 929 artikelträffar. De 929 artiklarna gicks igenom manuellt och de artiklar som berörde förändringen inom distriktsveterinärorganisationen arkiverades i kronologisk ordning. De artiklar som rörde veterinärer men som inte kunde relateras till omorganisationen (Exempelvis: "Felbehandling av veterinär i Söderköping") lades åt sidan. Återstående 37 artiklar förekom i totalt fyra dagstidningar från mars till augusti. Utifrån detta kronologiska grundmaterial sammanställdes den översikt över den massmediala bilden av omorganisationen som återfinns integrerad i kapitel 2.

I en andra dokumentstudie lade jag fokus på Svensk veterinärtidning, Sveriges veterinärförbunds egen tidning. Jag gick systematiskt igenom samtliga nummer mellan åren 2000-2013 med avsikt att få en bild av professionens utveckling och för att studera hur genus gjordes vad gällde djurslag. Fokus fästes vid såväl text som bilder. 
Denna genomgång fungerade som en bakgrund till fördjupningen i och nytolkningen av intervjumaterialet 2015.

\section{Kartläggning av företag för urval}

En ${ }^{30}$ kartläggning av samtliga företag med veterinärverksamhet i Östergötland har utgjort ytterligare en viktig del i forskningsprocessen då det var på detta vis urvalet till intervjuerna gjordes. Kartläggningen syftade även till att få en överblick över den privata veterinärsektorn i länet. Viktiga verktyg i kartläggningen var den ekonomiska databasen Affärsdata.se i kombination med databasen Allabolag.se. Vid sökningar i båda databaser har SNI-kod 75000 (veterinärverksamhet) använts i kombination med en avgränsning till regionen. Det var nödvändigt att kombinera två databaser då Affärsdata.se inte gav information om enskilda firmor. Dessa uppgifter hämtades istället ur databasen Allabolag.se. Vid sidan av detta genomsöktes Internet utifrån respektive företagsnamn för att kontrollera förekomsten av officiella hemsidor. De hemsidor som kunde kopplas till ett företagsnamn scannades för relevant information och arkiverades.

\section{Intervjustudie}

Intervjustudien $^{31}$ har stora likheter med det som kan beskrivas som en livsberättelseansats, en ansats som lämpar sig väl för analyser där människan ses som ett aktivt subjekt (Berglund \& Johansson, 2007). Ett kännetecken för livsberättelsen är att den är retrospektiv och ger mening åt det förflutna ur nuets perspektiv (Öberg, 2011). Det är därmed inte det inträffade händelseförloppet som studeras utan redogörelsen för detta (Nylén, 2005). Retrospektivt meningsskapande av veterinärernas erfarenheter är också vad som har karaktäriserat intervjuerna i denna studie. Forskningsintervjun har utgjort en arena för intervjupersonerna att berätta om sig själva i förhållande till de övergripande temana. I denna studie är det dessa valda delar av intervjupersonernas liv som är av intresse, det vill säga det är inte hela deras livshistoria som har varit fokus i intervjuerna.

Underlaget för intervjustudien är den kartläggning av företagare och könsfördelning som gjorts. Intervjupersonerna valdes ut på basis av klassificering som veterinärer, företagare och kvinnor. Den definition av företagare som använts är densamma som

\footnotetext{
${ }^{30}$ Innehållet under denna rubrik är helt eller delvis text från min licentiatavhandling (Appelkvist, 2013: 39-40)

${ }^{31}$ Innehållet under denna rubrik är helt eller delvis text från min licentiatavhandling (Appelkvist, 2013: 41-44)
} 
används av svenska myndigheter (jmf Sundin, 2010). Intentionen var att genomföra en totalstudie, det vill säga att intervjua samtliga veterinärer som är kvinnor och företagare i Östergötland. Med utgångspunkt $\mathrm{i}$ kartläggningen upprättades listor över veterinärer tillika kvinnor inom länet som klassificerades som företagsägare I början av 2011 identifierades totalt 11 relevanta intervjupersoner. I de fall företagen hade officiella hemsidor användes dessa för att tillgå kontaktinformation. I övriga fall kunde kontaktinformation inskaffas med hjälp av olika internetverktyg för kontaktuppgifter.

Som en första, inledande språngbräda till intervjustudien genomfördes under hösten 2010 en pilotintervju med en kvinna tillika företagande veterinär i Östergötland. Syftet med pilotintervjun var främst att pröva en preliminär intervjuguide men även att få inspiration till forskningsfrågor och studiens inriktning. I och med denna vida ingång blev denna pilotintervju ett samtal om både högt och lågt. En andra intervjuguide (bilaga 1) med smärre förändringar togs fram utifrån detta samtal. Empiriinsamlingen tog sin början i februari 2011 och pågick fram till september samma år. En anledning till denna utsträckning i tid var svårigheter att få tag på samt boka in intervjutillfällen med veterinärerna ifråga.

Kontakter togs via antingen telefon eller mail löpande under våren och intervjuer bokades in utifrån intervjupersonernas önskemål om dag, tid och plats. Studien presenterades via mail eller över telefon för intervjupersonerna såsom inriktad mot kvinnors företagande. På detta sätt presenterades den även vid varje intervjus inledning. Jag förklarade att jag var intresserad av förutsättningar för kvinnors företagande och att veterinärprofessionen var ett intressant sammanhang för detta. Innan varje intervju sammanställdes en mapp innehållande intervjuguide, bolagsinformation, utskrift av eventuell företagshemsida samt en vägbeskrivning. Det senare var många gånger nödvändigt då flertalet företag var situerade på landsbygden. Sammanställningen av denna mapp tjänade som en mental förberedelse inför intervjun samtidigt som den även tjänade sitt praktiska syfte med att tillhandahålla viktig information på ett lättillgängligt sätt. Denna strukturering hade jag nytta av vid flera tillfällen under studiens gång.

Intervjuerna varade i genomsnitt 1,5 timme. Intervjuerna spelades in digitalt och jag transkriberade dem själv i sin helhet för att underlätta det kommande analysarbetet. Sammanlagt genomfördes 13 intervjuer inom denna del av studien (för en sammanställning se tabell 4-1). Totalt tio av kartläggningens elva identifierade intervjupersoner gav sitt samtycke till att intervjuas ${ }^{32}$. Medelåldern för de intervjuade var 51,5 år där den yngsta var 39 och den äldsta 63. En av veterinärerna (Anja ${ }^{33}$ ) intervjuades vid flera tillfällen då hon startade upp sitt nuvarande företag parallellt

\footnotetext{
${ }^{33}$ Samtliga intervjupersoners namn är fingerade i denna avhandling
} 
med att denna studie genomfördes. Den första intervjun genomfördes innan hon fått tillträde till det nya företagets lokaler och den andra intervjun efter att företagets verksamhet öppnats för allmänheten. Däremellan skedde även en kort telefonintervju för en uppdatering om företagets status. Beatrice intervjuades två gånger, då hon var den som pilotintervjun genomfördes med. Syftet var att täcka in den uppdaterade intervjuguiden.

Intervjuguiden utformades som en lista med teman och kan benämnas som semistrukturerad (Bryman \& Bell, 2005). Detta innebär att intervjuprocessen är flexibel och medger att intervjupersonen har stor frihet att utforma svaren på sitt sätt. Semistrukturerade eller temabaserade intervjuer har fördelen att de på ett tydligt sätt markerar för intervjupersonen att det är dennes berättelse som är basen för intervjun, snarare än på förhand utarbetade och specifika frågor (Thomsson, 2010). På detta sätt lade detta intervjusätt också grunden till det som kom att utvecklas till livsberättelser. De teman som inkluderades i intervjuguiden omfattade aspekter som intervjupersonernas bakgrund avseende både profession och företagande samt omständigheter kring företagsetablering och nuvarande verksamhet. Intervjuguiden användes främst som en checklista i slutet av intervjun, för att stämma av att inget väsentligt missats. 


\begin{tabular}{|c|c|c|c|c|}
\hline \multicolumn{5}{|c|}{ Tabell 4-2: Översikt intervjustudie } \\
\hline Intervjuperson & Datum & Längd & Plats & $\begin{array}{l}\text { Typ av } \\
\text { datainsamling }\end{array}$ \\
\hline $\begin{array}{l}\text { Chef DVOs } \\
\text { huvudkontor }\end{array}$ & $14 / 4-2010$ & $25 \mathrm{~min}$ & Telefon & $\begin{array}{l}\text { Orienterande } \\
\text { intervju }\end{array}$ \\
\hline $\begin{array}{l}\text { Länsveterinär } \\
\text { Östergötland }\end{array}$ & $20 / 4-2010$ & $3 \mathrm{~h} 4 \mathrm{~min}$ & $\begin{array}{l}\text { Östergötland } \\
\text { med bil }\end{array}$ & $\begin{array}{l}\text { Orienterande } \\
\text { observation/ }\end{array}$ \\
\hline & & & & intervju \\
\hline Rebecca & $26 / 1-2011$ & $2 \mathrm{~h} 6 \mathrm{~min}$ & Företaget & Intervju \\
\hline \multirow[t]{5}{*}{ Anja } & $2 / 2-2011$ & 1h $11 \mathrm{~min}$ & Hemmet & Observation/ \\
\hline & & & & Intervju \\
\hline & $31 / 3-2011$ & $6 \mathrm{~min}$ & Telefon & Intervju \\
\hline & $16 / 8-2011$ & 1h 13 min & Företaget & Observation/ \\
\hline & & & & Intervju \\
\hline Lena & $7 / 2-2011$ & 1h $43 \mathrm{~min}$ & Universitetet & Intervju \\
\hline Sandra & $4 / 5-2011$ & 1h $31 \mathrm{~min}$ & Företaget & Intervju \\
\hline Eva & $1 / 6-2011$ & 1h $5 \mathrm{~min}$ & Företaget & Intervju \\
\hline Susanna & $24 / 8-2011$ & $53 \mathrm{~min}$ & Företaget & Intervju \\
\hline \multirow[t]{2}{*}{ Annika } & $8 / 9-2011$ & 1h $21 \mathrm{~min}$ & Företaget/ & Observation/ \\
\hline & & & hemmet & Intervju \\
\hline Karin & $7 / 10-2011$ & $53 \mathrm{~min}$ & Restaurang & Intervju \\
\hline \multirow[t]{2}{*}{ Beatrice } & $26 / 9-2010$ & $2 \mathrm{~h}$ & Företaget & Pilotintervju \\
\hline & $19 / 10-2011$ & 1h $29 \min$ & Restaurang & Intervju \\
\hline Christina & $24 / 10-2011$ & 1h 55 min & Företaget & Intervju \\
\hline
\end{tabular}

En majoritet av intervjuerna genomfördes i intervjupersonens företagslokaler och oftast då i fikarummet. En intervju genomfördes på universitetet och två i intervjupersonernas privata hem. Ytterligare två utfördes på en restaurang. Platsen för intervjun kan ha betydelse för såväl kontakten mellan intervjuare och intervjuperson och även inverka på intervjupersonens benägenhet att öppna sig (Bryman \& Bell, 2005; Trost, 2005). Det primära motivet för studien varit att få möjlighet att genomföra intervjuerna och därför har intervjupersonerna fått vara styra val av plats.

Ledord för samtliga intervjutillfällen har för mig varit följsamhet. Thomsson (2010) lyfter fram aspekter som att kunna skämta och hitta gemensamma nämnare som ett 
sätt att undvika distanserade och forcerade intervjuer. Min strategi för att skapa en god kontakt och att bygga en känsla av förtroende i situationen har förutom detta varit att fokusera min egen närvaro i intervjusammanhanget. Att förmedla närvaro i ögonblicket och ett intresserat lyssnade är av stor vikt $\mathrm{i}$ intervjusituationen då det visar på intervjuarens vilja att höra intervjupersonens berättelse (Thomsson, 2010; Öberg, 2011). Samtidigt menar jag att det för intervjuaren kan vara vanskligt att närvara i ögonblicket då risken är att intervjupersonen får allt för stort utrymme att breda ut sig om mindre relevanta aspekter. Dessutom är det lätt att tappa bort såväl intervjufrågor som tidsperspektiv.

Varje intervjutillfälle har präglats av en flexibilitet vad gäller fokus. I början av intervjustudien tenderade intervjuerna att vara vida i sitt fokus för att löpande i processen styras om och smalnas av. Varje intervju kan därför ses som en utveckling av föregående då intervjun med en person bidrog med insikter till intervjun med nästkommande person. I detta fall menar jag att det har varit en fördel att utföra intervjuerna under en längre tidsperiod då detta lämnat utrymme för eftertanke och vidareutveckling. Detta är något som Kvale (2014) för fram som en av fördelarna med just intervjuer - att forskaren kan blotta nya och oväntade aspekter som vidgar och förändrar hens uppfattning av de studerade fenomenen.

Dokumentstudien var till stor hjälp i genomförandet av intervjuerna då jag delvis var insatt i veterinärsektorns uppbyggnad och olika förkortningar för dess organisationer. Jag kunde även relatera till mina egna erfarenheter som hundägare för att finna en gemensam grund med intervjupersonerna. Detta menar jag är en styrka jag haft i intervjusituationen. Samtidigt föreligger en risk i att tro sig veta mer än vad man gör. Som intervjuare är det viktigt att vara vaksam och att inte ge sken av att kunna mer än vad som är fallet. Följaktligen kunde jag i vissa fall nicka igenkännande medan jag i andra behövde ställa specifika frågor om exempelvis olika beteckningar och procedurer.

Med en tematiserad intervjuguide och öppna frågor har jag bett intervjupersonerna berätta om sina liv och val de gjort - främst i förhållandet till företagande och profession. Intervjutekniken har präglats av ett aktivt lyssnande med inslag av löpande uppsummeringar (så efter att du fått din legitimation...), förtydligande frågar (när var det?), återkopplingar till sådant som sagts vid ett tidigare tillfälle (du sa tidigare...). Jag har som intervjuare haft en tillbakadragen roll på så sätt att jag främst lagt fokus på att ta del av intervjupersonernas berättelser. Risken med detta sätt att intervjua är ett visst beroende av intervjupersonens öppenhet för att prata fritt, det empiriska underlaget riskerar därmed att bli disparat i sin karaktär.

Förutom att presentera intresset för kvinnors företagande inledningsvis så ställdes begränsat med direkta frågor om detta tema respektive genus i allmänhet under 
intervjuerna. Däremot ställdes uppföljningsfrågor på sådant jag uppfattade som intressant i förhållande till studiens inriktning. Det vill säga jag ställde uppföljande frågor och bad intervjupersonerna förklara eller berätta mer vid de tillfällen då det jag identifierade som intressant ur genusperspektiv uppkom spontant $i$ deras berättelser. En fråga som ställdes till samtliga intervjupersoner i samband med deras berättelser om utbildningsåren var den om könsfördelningen i klassen.

I och med att intervjuerna, som ovan beskrivits, i hög grad kom att bli till livsberättelser fick jag veta mycket om flera delar av intervjupersonernas liv, såsom exempelvis familjesituationen. Dylik information var inget som efterfrågades i intervjusituationen. Berättelserna om profession och företagande är tätt sammantvinnade med andra avgörande händelser i livet såsom när ett barn föds eller vid en skilsmässa. Där sådant är relevant för företagande kommer det att beskrivas i resultatkapitlet.

Intervjuerna gav vid flera tillfällen möjlighet till spontana observationer. Antingen inledningsvis då intervjupersonen behövde göra klar en uppgift innan intervjun (ta hand om en hund med en infektion eller ge en hund en spruta) eller mitt i intervjun för att ta hand om en situation (ge rådgivning $i$ telefon, ta hand om en spontant inbokad patient, ta emot en travhäst för senare utredning). Dessa företeelser kan ses som störningsmoment. Jag såg dessa observationer som en möjlighet att ge en rikare empirisk beskrivning samt att få en inblick i företagarens vardag.

I nära anslutning till varje intervju skrevs minnesanteckningar. Fokus för dessa anteckningar var egna intryck från intervjutillfällena som exempelvis känslan av kontakt med intervjupersonen samt en beskrivning av omgivning i vilken intervjun utfördes (jmf Bryman \& Bell, 2005). Dessa minnesanteckningar tjänade som bakgrund till de transkriberade intervjuerna (jmf Kvale \& Brinkmann, 2014). Då tillfälle gavs fotograferade jag företagets entré och/eller besöksrummet som ett sätt att dokumentera intervjuernas omgivningar. Såväl minnesanteckningar som fotografier hjälpte mig att sätta in de transkriberade intervjuerna i ett sammanhang då det gått en tid efter intervjutillfället (jmf Thomsson, 2010). Med hjälp av dessa kunde jag lättare minnas den specifika intervjusituationen och känslan av kontakt.

Då vi gör genus är att vi medvetna om att vi kommer att bli bedömda av andra (West \& Zimmerman, 1987). I intervjusituationen kan det inte uteslutas att någon intervjuperson förhöll sig till mig så som en potentiell bedömare. Det var dock inte min upplevelse. Jag upplevde att de flesta kände sig fria att uttrycka sig i samtal med mig såsom kvinna med specifikt intresse för kvinnors företagande. Vid ett par intervjutillfällen blev det tydligt att intervjupersonen ställde sig skeptisk till behovet att tala om kvinnors företagande. Detta kan ses som ett uttryck för den strategi Bird och Rhoton (2011) betecknar som "hävda neutralitet" d.v.s. en personlig genusstrategi som kvinnor i mansdominerade professioner utvecklar. Liknade kan det ses som ett 
sätt att försöka undkomma att märkas och konstrueras som avvikande (jmf Lewis, 2006).

\section{Litteraturstudie}

Under 2014 genomförde jag en kompletterande systematisk litteraturstudie av forskningslitteratur med syfte att skapa en kunskapsbank och översikt över tidigare forskning av relevans för studien. Strukturerade sökningar efter såväl vetenskapliga artiklar som böcker och kapitel i antologier gjordes med hjälp av databaserna Scopus och Libris ${ }^{34}$. Fokus för sökningarna var studier som inkluderade de tre teoretiska fälten av småföretagande, profession och genus. Det var främst överlappningarna mellan dessa fält som var av intresse i sökningarna (se figur 4-1).

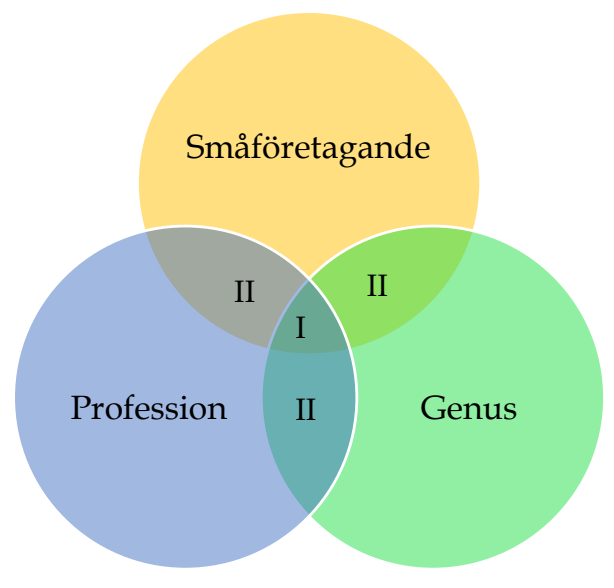

Figur 4-1: Överlappningar mellan småföretagande, profession och genus

Inledningsvis lades fokus vid punkt I där samtliga tre teman överlappar varandra. Resultatet av denna sökning blev förhållandevis litet. Därefter lades fokus vid punkt II, det vill säga vid forskning som inkluderade två av de tre temana i olika konstellationer. Avslutningsvis gjordes även tillägg av forskning för att ge en bakgrund till vart och ett av temana. Detta gjordes i form av sökningar kombinerade med snöbollsmetoden utifrån tidigare kända referenser. Via dessa kunde

\footnotetext{
${ }^{34}$ Inledningsvis användes även Google Scholar samt ISI Web of Science för sökningar. Scopus inkluderar dock fler tidskrifter än ISI och är ett databaskopplat sökverktyg medan Google Scholar är en sökmotor. Därmed föll det slutliga valet på en kombination av databaserna Scopus och Libris för den mer systematiska litteratursökningen.
} 
fördjupningar göras. I Libris gjordes sökningar på både svenska och engelska, i Scopus enbart på engelska. Manuella sökningar gjordes även av tre tidskrifter som identifierats som intressanta men som inte ingick i Scopus. För en mer detaljerad beskrivning av dessa litteratursökningar se bilaga 4 .

Listorna på referenser som kom av dessa sökningar kondenserades genom en granskning av abstrakt för artiklar och översiktlig scanning av böcker och kapitel för att sortera bort sådant som bedömdes som irrelevant. Resultatet av denna litteraturstudie blev en lista innehållande 61 artiklar samt 36 böcker/kapitel i böcker. Samtliga texter bearbetades och anteckningar fördes i ett Exceldokument utifrån en uppdelning av aspekter som nyckelord, syfte, slutsatser, vetenskapssyn, metod och empiriskt fokus.

\section{Analys}

Som ett första steg i det fördjupade analysarbetet gick jag tillbaka till intervjumaterialet för att åter bekanta mig med det. En tid hade passerat sedan intervjuerna genomfördes och analyserades till licentiatavhandlingen och jag hade fått distans till mitt material. Detta underlättade processen att på nytt närläsa och ta in de transkriberade intervjuerna. Denna genomläsning gjordes ett flertal gånger och jag gick även tillbaka till ljudfilerna i de fall där jag kände behov av att lyssna in tonfall och rytm. Materialet vidgade sig åter för mig och jag kände den bekanta känslan av att omslutas av empirin. Detta ser jag som ett tydligt tecken på att jag var redo att studera materialet med andra ögon. Med detta menar jag att jag hade släppt tidigare tematiseringar av materialet och åter såg det i sin helhet.

I ett första steg gjordes en systematisk reducering av samtliga intervjuer utifrån de transkriberade textdokumenten där jag korrigerade språk och tog bort upprepningar för att på så sätt få fram en mer lättillgänglig text. Mina egna små korta inlägg i form av "jaha ja", "jasså" och hmmanden togs helt bort från texten. Att reducera materialet i flera olika steg är ett sätt att hantera det faktum att man inte kan återge allt det som finns dokumenterat (Rennstam \& Wästerfors, 2015). Denna inledande reducering var främst språklig och begränsad för att inte tappa vare sig detaljer eller helheter (jmf Öberg, 2011). Se exempel i tabell 4:3 nedan. 


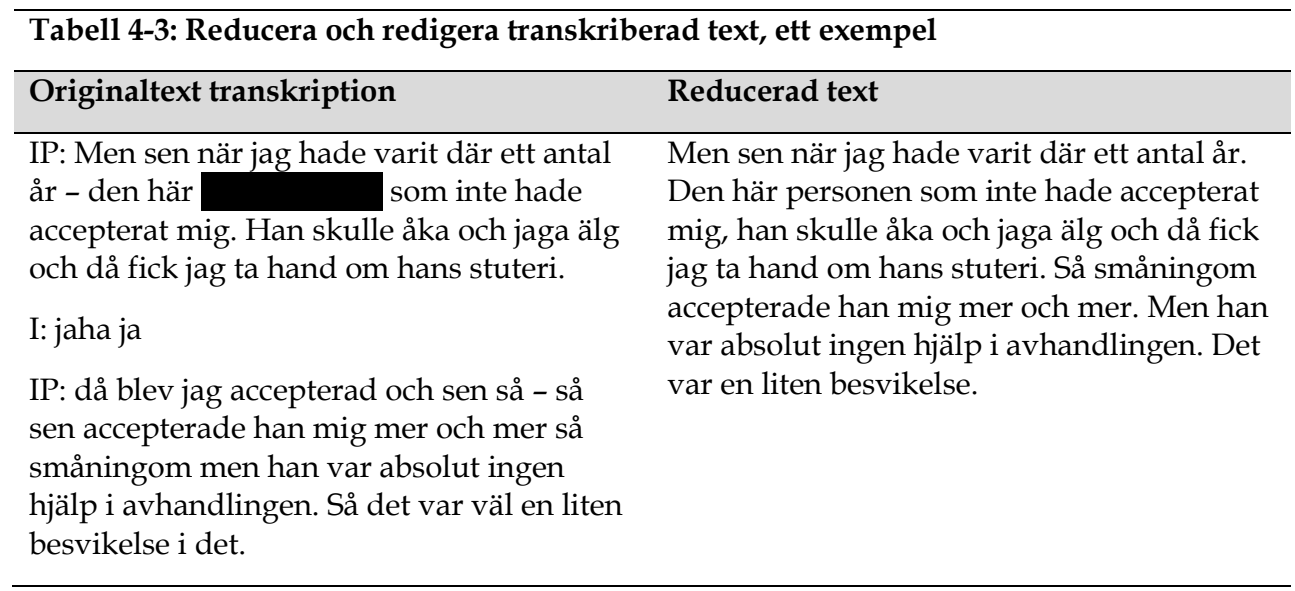

I nästa steg inleddes en kategorisering av materialet. De huvudkategorier som användes var företagande och genus, profession och genus samt företagande och profession. Dessa kategorier konstruerades i relation till studiens syfte och frågeställningar, särskilt vad gäller hur genus görs i företagande respektive profession. Den tredje kategorin uppstod utifrån ett behov av att öppna upp för de aspekter av intervjumaterialet där profession och företagande inte kunde skiljas ut från varandra. Dessa huvudkategorier uppkom under studiens gång och genererades induktivt då jag i genomläsningen av intervjuerna identifierade en komplexitet i förhållandet mellan profession, företagande och hur genus görs.

Ett dokument upprättades för varje intervjuperson med en indelning utifrån dessa kategorier och dit kopierades textstycken från den reducerade transkriptionen som kunde knytas till någondera kategori. Genom att identifiera hela stycken snarare än att välja ut enstaka meningar bibehölls berättelsernas sammanhang samtidigt som textmassan i förhållande till det transkriberade materialet minskades. Även denna bearbetning gjordes såväl direkt på dator som med hjälp av pennor och papper. I denna inledande kategorisering eftersträvade jag ett inkluderande förhållningssätt i urvalet. Därefter följde en process av att sammanföra den övergripande kategoriseringen och ta ett samlat grepp på intervjupersonerna en kategori i taget (se tabell 4-4). Vad var den samlade bilden av hur genus görs i företagande? 
Tabell 4-4: Sammanförande av kategorisering

\begin{tabular}{|c|c|c|c|c|c|c|}
\hline Huvudkategori & Anja & Annika & Beatrice & Christina & $\ldots$. & .... \\
\hline \multicolumn{7}{|l|}{$\begin{array}{l}\text { Företagande - } \\
\text { genus görs }\end{array}$} \\
\hline \multicolumn{7}{|l|}{$\begin{array}{l}\text { Profession - } \\
\text { genus görs }\end{array}$} \\
\hline $\begin{array}{l}\text { Företagande och } \\
\text { profession }\end{array}$ & & & & & & \\
\hline
\end{tabular}

Efter denna sammanställning studerade jag materialet inom varje huvudkategori. Vilka delkategorier kunde identifieras i de berättelser som lyftes fram inom varje huvudkategori (se tabell 4-5)? Fokus låg här på att inom varje identifierad kategori konstruera berättelser med inslag av såväl likheter som mångfald. Frågan "vad handlar det här om" har varit vägledande under denna del av kategoriseringen.

Tabell 4-5: Identifiering och framskrivning av teman

\begin{tabular}{ll}
\hline Huvudkategori & Teman \\
\hline $\begin{array}{l}\text { Företagande - } \\
\text { genus görs }\end{array}$ & 1 Val att bli företagare \\
& 2 Anpassningar \\
& $3 \ldots \ldots \ldots$ \\
Profession - & 1 Förändringar i professionen \\
genus görs & 2 Djur \\
& $3 \ldots \ldots .$. \\
Företagande och & 1 Frihet \\
profession & 2 Ambitioner \\
& $3 \ldots \ldots \ldots \ldots$
\end{tabular}

På detta vis har jag lagt tonvikt vid intervjuernas innehåll snarare än letat efter sådant som jag på förhand definierat. Detta sätt att arbeta har stora likheter med det som förespråkas inom grundad teori (jmf Alvesson \& Sköldberg, 2008). I skrivprocessen av det som kom att bli resultatkapitlen reviderades dessa kategoriseringar löpande. Texten har bearbetats och skrivits om i flera steg. Citaten har valts utifrån premissen att de ska förtydliga och understryka de tolkningar som gjorts från materialet för 
läsaren. Avsikten har dock även varit att bejaka den empiriska mångfalden, och ge utrymme för pluralism och motsägelse.

Att beskriva en analysprocess är svårt. Den består av ett otal små och stora steg, såväl praktiska som tankemässiga. Skrivande, att sätta tankar på pränt, resulterar å ena sidan förr eller senare i en "färdig" produkt. Men produkten är å andra sidan resultatet av en process och kan ses som ett instrument för självreflektion. Idéer existerar innan den skrivna texten men det är först $\mathrm{i}$ textform som de tar form, prövas och omprövas (Colyar, 2009). Delar av analysen har även i denna studie skett i samband med skrivandet av densamma (jmf Olson, 1996).

\section{Kvalitet}

Avslutningsvis finner jag det relevant att diskutera studiens kvalitet samt säga något om de etiska överväganden som gjorts. Beroende på om det handlar om en kvantitativ eller kvalitativ studie lyfts olika kvalitetskriterier fram. De kvalitetskriterier som applicerbara på denna studie är koherens, konsistens och transparens (Justesen \& Mik-Meyer, 2011). Koherens och konsistens fokuserar båda logiska sammanhang och handlar om att det inte får finnas motsägelser i studien. Med koherens betonas att problemformulering, teoretiska resonemang och metodval hänger ihop. Konsistens lägger snarare fokus på begrepp, metoder och teorier utifrån att begrepp som används i studien ska vara klart definierade. Både koherens och konsistens har varit vägledande genom hela forskningsprocessen och har diskuterats vid olika seminarier och i andra sammanhang. En studies transparens är grundläggande för att dessa övriga kvalitetskriterier ska kunna bedömas. I mångt och mycket är hela meningen med detta kapitel att beskriva och diskutera vilka metodologiska val som gjorts och varför.

Till dessa mer grundläggande kriterier vill jag även lägga de av Justesen och MikMeyer (2011) föreslagna kriterierna för konstruktivistisk forskning. Att avgöra huruvida denna studie är övertygande, relevant och intressant är i viss mån är upp till läsaren själv att bedöma. Jag anser dock att studien utgörs av relevant och intressant kunskap för flertalet målgrupper, såväl inom som utom akademin. En redogörelse för studiens implikationer återfinns i kapitel XX. Att göra bedömningen om studien är övertygande och trovärdig hoppas jag att bland annat detta kapitel lägger grund för.

I detta sammanhang är även kriteriet reflexivitet relevant (Justesen \& Mik-Meyer, 2011). Reflexivitet är besläktat med transparenskriteriet då det tar sin utgångspunkt i att jag som forskare ska blottlägga mina reflektioner för läsaren. Reflexivitetskriteriet går dock ett steg längre och innebär även att jag som forskare ska reflektera över vad min egen position och erfarenhet betyder för undersökningen. Jag har vinnlagt mig 
om att visa på reflexivitet $\mathrm{i}$ denna studie bland annat genom att diskutera min egen bakgrund och förförståelse men även genom att så långt som möjligt diskutera kring min del i studien såsom medskapare av resultaten. Genom sina berättelser skapade intervjupersonerna mening åt sina erfarenheter. De konstruerade och kommunicerade sin uppfattning om världen, sig själva och andra (jmf Johansson, 2012). Jag gör i denna studie därmed tolkningar av intervjupersonernas tolkningar av sig själva och sina sociala världar.

\section{Etiska överväganden}

Studien har präglats av de forskningsetiska principer vad gäller humanistisksamhällsvetenskaplig forskning som Vetenskapsrådet (2002) tagit fram. De fyra huvudkraven innefattar informationskravet, samtyckeskravet, konfidentialitetskravet och nyttjandekravet.

Intervjupersonerna informerades om studiens syfte och gav informerat samtycke vid inledningen av respektive intervjutillfälle. De informerades om att deltagandet var frivilligt och att de när som helst kunde välja att avbryta intervjun. De informerades och gav även sitt samtycke till att jag spelade in intervjuerna digitalt (jmf Kvale \& Brinkmann, 2014). Jag har i skrivandet av denna text eftersträvat konfidentialitet för intervjupersonerna framförallt genom att använda fingerade namn. Med detta sagt så är antalet veterinärer i Östergötland begränsat och det skulle kunna gå att identifiera intervjupersonerna av en, på området, initierad person. Jag bedömer dock att intervjuerna handlar om sådant som intervjupersonerna skulle stå för oavsett sammanhang. Ändå har jag som författare vinnlagt mig om att inte skriva något som kan vara skadligt för intervjupersonerna eller deras företagande.

Det insamlade materialet har behandlats med största möjliga konfidentialitet vad gäller förvaring och hantering och har endast använts för forskningsändamål. 
Del 2 


\title{
Kapitel 5
}

\section{Veterinärporträtt}

\begin{abstract}
Dorträtten ${ }^{35}$ nedan innehåller en presentation av var och en av de intervjuade veterinärerna (namnen är fingerade) och är baserad på information från intervjutillfället. I bilaga 5 finns en översikt över intervjupersonerna och deras företagande.
\end{abstract}

\section{Karin - Fri som vinden}

Karin är 63 år och den äldsta av de intervjuade veterinärerna. Även om viljan var stark var vägen till veterinärutbildningen inte spikrak. Karin kom in på utbildningen först på det fjärde försöket, år 1971. Vid tiden för sin examen fanns fortfarande en viss skepsis inför kvinnor i professionen, något som Karin dock menar kunde mildras om man visade sin färdighet. Direkt efter utbildningen arbetade Karin under några år som distriktsveterinär. Hon sökte sig dock snart tillbaka till lantbruksuniversitetet med en ambition att forska på hästar och tidig fosterdöd. Produktionens djur var dock de som vid den tiden prioriterades vid universitetet och Karin fann sig ingå i ett forskningsprojekt om galtsperma under några år. Med ett stort mått av envishet lyckades hon till slut komma in i ett forskningsprojekt och hennes avhandling inriktad mot hästobstetrik ${ }^{36}$ stod färdig 10 år senare; 1992. Parallellt med avhandlingsarbetet hann Karin och hennes man med att få tre barn samtidigt som de byggde upp en egen verksamhet med inriktning mot semin ${ }^{37}$. Karin startade sin nuvarande verksamhet år 2002. Det är en verksamhet som genom åren har transformerats. Under några år hade

\footnotetext{
${ }^{35}$ Detta kapitel bygger helt eller delvis på text från min licentiatavhandling (Appelkvist, 2013: 91-97 samt bilaga 7).

36 Obstetrik = förlossningslära.

${ }^{37}$ Seminering av djur för avel.
} 
Karin en fast punkt på en gård och även anställda, numera är hon dock såväl ambulerande som ensam i verksamheten. Med sin husbil och Östergötland som utgångspunkt far Karin land och rike runt. Verksamheten består av semin, frysning av sperma samt embryotransfer, allt med fokus på hästar. Vad gäller embryotransfer är hon en av tre i Sverige som utför detta. För Karin är det framför allt friheten med företagandet som lockar och med en ambulerande verksamhet uppnår hon kanske den yttersta friheten.

\section{Beatrice - Gammal i gemet}

Beatrice är 60 år och kommer ursprungligen från Stockholm. Hon har alltid haft ett intresse för djur. Betygen från gymnasiet gjorde dock att veterinärprogrammet tycktes ouppnåeligt och hon kom istället att utbilda sig till biolog och arbetade under flera år som labbingenjör. Veterinäryrket fortsatte dock att locka och slutligen gjorde Beatrice högskoleprovet. Med de erhållna poängen öppnades möjligheten att söka till veterinärprogrammet och utbildningen påbörjades när hon var i 30-årsåldern. Efter utbildningen bosatte sig Beatrice i Östergötland och började vikariera som distriktsveterinär. Förutom distriktet i Östergötland vikarierade hon även i ett distrikt i Värmland. På grund av missnöje i samband med omorganisationen av distriktsveterinärorganisationen år 1995 valde Beatrice att starta eget företag. Beatrices verksamhet har, vid tiden för intervjun, funnits i 17 år och är väl etablerad. Den lilla kliniken ligger mitt inne i stadskärnan i en stad i Östergötland och här tar hon tillsammans med en timanställd veterinär hand om stadens hundar och katter. Även hästar och andra stora djur behandlas men då i sina hemmastall. På sommarhalvåret har Beatrice även en inriktning mot semin. Beatrice har ett mångårigt hästintresse och har även egna hästar. 


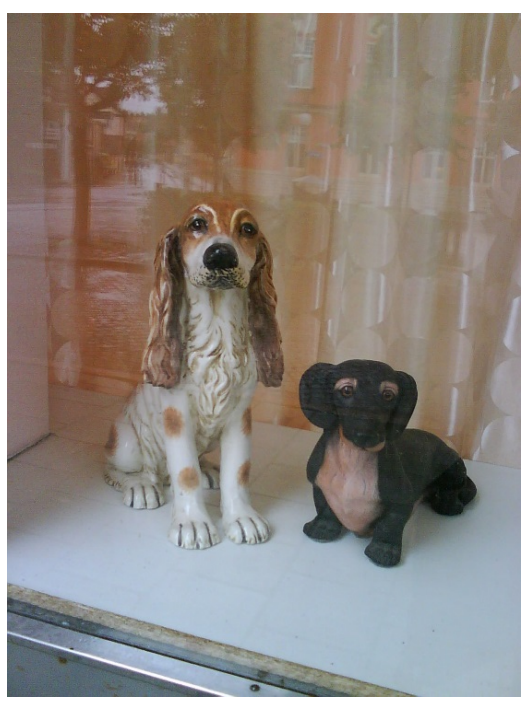

Skyltfönster till veterinärklinik, Foto: Författaren, 2011

\section{Christina - Med den stora hästkliniken}

Christina är 56 år, född i Sydamerika och hade tidigt ett intresse för såväl djur som natur. Detta intresse ledde henne till att, i ett utslag av skoltrötthet efter gymnasiet, söka arbete på en smådjursklinik. Erfarenheten grumlade dock viljan att bli veterinär då arbetsplatsen präglades av dålig stämning och en nedlåtande attityd från veterinärens sida gentemot djurägarna. Det var något som Christina starkt vände sig mot och under några år släppte hon därför tankarna på att bli veterinär och utbildade sig istället till förskolelärare. Tankarna om att bli veterinär försvann dock aldrig riktigt och år 1983 sökte hon och kom in på veterinärutbildningen. Efter examen följde en snabb karriär som distriktsveterinär, privatanställd men även som lärare. Efter att ha flyttat till Östergötland såg Christina att det fanns behov av en hästklinik i länet. En insikt som involverade henne i ett antal olika projekt med inriktning mot att öppna en klinik. Men av olika anledningar realiserades aldrig projekten. Först när hon mötte sin nuvarande partner blev drömmen verklighet och hästkliniken kunde byggas med Christina som ledare för den operativa verksamheten och med partnern främst fokuserad på administration. Kliniken är belägen ute på landsbygden, inrymd i en stor ladugårdsliknande byggnad. Till en början etablerades kliniken återhållsamt då Christina ville säkerställa det befintliga kundunderlaget. Efter hand har dock verksamheten utökats och såväl anställning av ytterligare veterinärer som tillbyggnad av lokalerna har varit nödvändiga. 


\section{Eva - Mitt i smeten}

Eva är 54 år och har pendlat fram och tillbaka mellan eget företagande och anställning ända sedan examen från veterinärutbildningen år 1981. Den första anställningen var dock som distriktsveterinär. Till en början arbetade hon med smådjur men det ändrades successivt allt mer mot häst. Sitt första företag startade Eva år 1984 och då med en inriktning mot semin och häst. Under flera år var även fokus på stuteriverksamhet. Några år senare, år 1990 valde Eva att byta företagande mot anställning vid en hästklinik i länet. Det hade varit mycket arbete med stuteriverksamheten och Eva kände ett behov av att göra något annat. Hon eftersökte såväl andra arbetsuppgifter som ett tillfälle att lära nytt. Sin nuvarande verksamhet startade Eva upp år 2001 och även denna gång berodde förändringen på ett behov av att göra något annat. Evas nuvarande verksamhet är strategiskt placerad, inte långt från hennes förra arbetsplats, mitt i ett kluster av travstall. Verksamheten är på grund av detta läge till viss del öppen för spontanitet. Det är enkelt att ta sin travhäst och promenera bort till Eva för att se om hon har tid.

\section{Annika - Med verksamheten i hemmet}

Annika är 53 år och hon kom in på veterinärprogrammet två år efter att hon tagit studenten. Efter examen från veterinärprogrammet år 1984 jobbade Annika som distriktsveterinär i några år. Därefter följde arbete vid flera olika kliniker i länet. Annika sade upp sig från en anställning i samband med att hon blev gravid med sitt första barn och påbörjade uppstarten av sitt företag parallellt med föräldraledigheten. Hon bor i en villa på landsbygden i Östergötland och i en tillbyggnad är verksamheten inhyst. Annika menar att det kan vara speciellt att ha sitt företag i hemmet. Det finns alltid något att göra och det är svårt att sätta sig och göra ingenting med verksamheten endast en dörr bort. Lokalen där verksamheten är inhyst har byggts om efterhand, till en början bestod den av ett enda stort rum. För den kund som behövde låna toaletten fick det bli den i huset, något som Annika tyckte var besvärligt på olika sätt - inte minst vad gällde integriteten. Ett av de första byggprojekten var just en gästtoalett. Numera finns även ett litet rum med utrymmen för den katt eller hund som behöver stanna över natten för observation. Annika behandlar i första hand sällskapsdjur. 


\section{Rebecca - I lugnet på landet}

Rebecca är 53 år och äger sin klinik tillsammans med sin make. Hon är dock ensam ansvarig för den kliniska verksamheten. Rebecca sökte veterinärutbildningen i såväl Finland som Sverige och tog slutligen sin examen år 1983 i Sverige. Den sista sommaren under utbildningen jobbade hon som distriktsveterinär och det var då hon blev särskilt intresserad av att arbeta med sällskapsdjur. Rebecca drev tillsammans med en manlig kollega en klinik mellan åren 1987-2005. Kliniken låg dock på en annan ort än bostaden och Rebeccas dagar upptogs till viss del av att pendla. Så småningom väcktes tanken att starta om på nytt med ett företag i närmare anslutning till hemmet. Förutom att slippa pendla ville Rebecca förverkliga drömmen om att skaffa en egen häst. Detta fanns nu goda möjligheter till, då det var gott om utrymme på hennes och makens gård. Rebecca väckte idén hos sin make att de skulle kunna renovera den ladugård som stod tom på gården och inrätta en egen verksamhet där. Kliniken startades sedermera år 2006 och dess slogan blev "Djursjukvård i hemmamiljö". Kliniken är belägen mitt ute på landsbygden och har en inriktning gentemot hund och katt. Rebecca menar att hon är nöjd med sitt kundunderlag och en dag i veckan ägnar hon sig åt företagets bokföring.

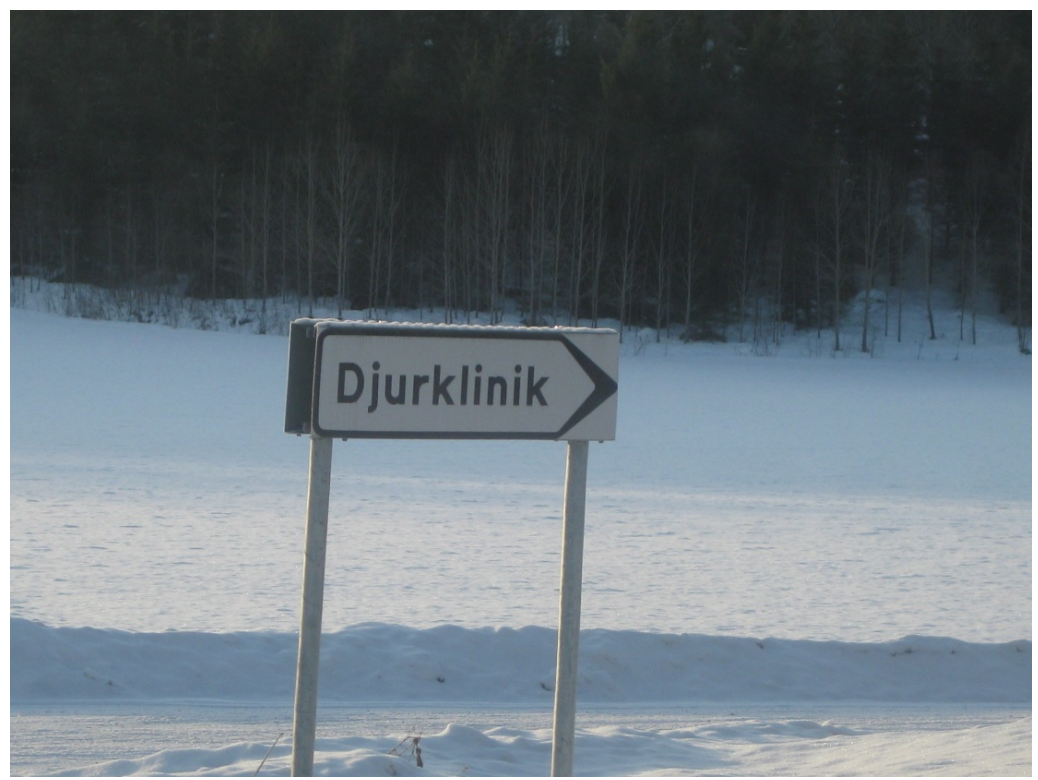

Väganvisning, Foto: Författaren, 2011 


\section{Sandra - Delvis ambulerande på landet}

Sandra är nyligen fyllda 50 år och hon var den första i sin släkt som erhöll högskoleutbildning. Som barn hade Sandra flera smådjur och när högstadiekompisarna passade barn för att dryga ut barnbidraget gick Sandra ut med andras hundar. Betygen från den naturvetenskapliga linjen räckte inte för att komma in på veterinärutbildningen och under några år jobbade Sandra bland annat som väktare, städerska, inom äldrevården och på sjön. Första gången hon sökte till veterinärutbildningen blev hon 594:e reserv på 65 platser. Året därefter avancerade hon till första reservplats. Det året kom hon också in då en antagen tackade nej till sin plats. Sandra startade sin veterinärutbildning år 1983 och blev färdig till årsskiftet 1988/1989. Från utbildningen blev hon direkt värvad till en klinik i en av Östergötlands större städer. En arbetsplats där hon inledningsvis trivdes men där arbetsförhållandena förändrades när hon återvände från föräldraledigheten. Med ett par mellanår som lärare i djursjukvård startade Sandra år 1994 sitt företag med inriktning mot både sällskapsdjur och häst. I ett inledande stadium var verksamheten lokaliserad till det egna hemmets källare, år 1998 flyttade dock Sandra in i sina nuvarande lokaler. Sandras klinik är belägen ute på den östgötska landsbygden och hon delar lokaler med ett byggföretag. Hon arbetar med såväl sällskapsdjur som hästar. Företagets lokaler är dock små och eftersom hon arbetar med hästar är Sandra därmed delvis ambulerande.

\section{Susanna - Familjeföretagare}

Susanna är 45 år och hade som ung hand om hästarna på en mjölkgård tillsammans med en kompis. Hon läste samhällsvetenskaplig linje på gymnasiet och spenderade efter studenten några år med att jobba och läsa in naturvetenskapliga ämnen på Komvux. Hon erhöll examen från veterinärutbildningen år 1995 och arbetade därefter bland annat som distriktsveterinär i åtta år. Susannas situation är speciell jämfört med övriga intervjupersoner då hon är delägare och verksam i ett företag som hon inte var med och startade upp från början. Det innebär att Susanna egentligen inte ser sig själv som företagare. Rollen som företagare ger hon istället sin make som startade företaget under 1980-talet. Susanna är dock i dagsläget till hälften delägare i företaget, aktiv i den dagliga verksamheten samt delaktig i alla ekonomiska beslut som fattas gällande företaget. I alla bemärkelser utom då kanske i sina egna ögon är Susanna därmed företagare. Veterinärrollen är enklare att förlika sig med för Susanna. Kontakt med sin make fick hon via en patient och han sökte efter en veterinär till sin verksamhet just under samma period. Susanna gick in som anställd i företaget och i och med omvandlingen från handelsbolag till aktiebolag blev Susanna delägare i företaget. Företaget, beläget på landet, har en inriktning mot djurtandvård och då främst häst. 


\section{Anja - Nystartande entusiast}

Anja 44 år, kommer ursprungligen från Nya Zeeland men fördes av såväl reslust som släktband till Sverige. Att utbilda sig till veterinär på Nya Zeeland lockade inte Anja, hon ville se Europa. Veterinärutbildningen i Sverige var, till skillnad från i många andra europeiska länder gratis och det var slutligen där Anja hamnade. Efter ett års språkutbildning började Anja på veterinärutbildningen år 1992. Efter att ha erhållit sin legitimation begav sig Anja till Irland för att jobba som stordjursveterinär. I samband med att mul- och klövsjukan kom styrde hon kosan mot England och jobbade där i ett år. Kliniska tjänster var dock svårt att få utomlands och när Anja väl ringde Sverige för att "kolla läget" rådde brist på veterinärer. Hon fick snabbt anställning på Jordbruksverket och jobbade även i flera år som distriktsveterinär på olika platser i Sverige. Det första företaget som Anja startade var ett konsultföretag med inriktning mot beredskap, smittskydd och sanering av gårdar. Det första året arbetade hon gentemot Jordbruksverket och utbildade personal $i$ användandet av ett datastödsprogram för större utbrott av djursjukdomar. Tanken var sedan att hon skulle börja leta andra kunder såsom saneringsföretag och myndigheter. Diagnosen med en allvarlig sjukdom kom dock i vägen, såväl nätverk som företagets ekonomi raserades under det år hon genomgick behandling. Efter några år som distriktsveterinär i såväl Piteå som Skåne har nu Anja riktat in sig på företagande igen och hennes nuvarande verksamhet startades under år 2011. Inom ramen för verksamheten behandlas såväl sällskapsdjur som häst och lantbruksdjur.

\section{Lena - På väg att ta steget}

Lena är 39 år och arbetade några år som djursjukvårdare innan hon kom in på veterinärutbildningen. Detta gav erfarenheter som var ovärderliga då det i årskurs 4 var dags att börja jobba kliniskt. Lena var då redan fingerfärdig i att sätta kanyler och hade tagit hand om avlivningar. Examen från veterinärutbildningen erhölls i årsskiftet 2005/2006 och några år därefter arbetade Lena på såväl en klinik som två djursjukhus. I uppstarten av sitt företag år 2009 fick Lena rådet av en vän och kollega att se till att inledningsvis ha en alternativ inkomst. Med en administrativ tjänst på 80 procent hos en myndighet var inkomsten säkrad och Lena började parallellt att bygga upp sin verksamhet. Efter fyra år håller Lena medvetet sin verksamhet kvar på 20 procent och hennes lokaler består egentligen av ett förvaringsutrymme i villans tvättstuga. Det faller sig dock naturligt då delar av hennes affärsidé handlar om att åka hem till kunden i samband med både undersökningar och avlivning. Lena har gott om visioner och idéer för sin verksamhet och deklarerar glatt att hon kommer att starta upp verksamheten till 100 procent när barnen (varav ett i magen vid intervjutillfället) är större. 
Kapitel 5: Veterinärporträtt 


\section{Kapitel 6}

\section{Livet som veterinär och företagare}

Tdetta kapitel kommer livet som veterinär och företagare stå i fokus. Resultaten presenteras i tematiserad form. Inledningsvis, i tabell 6-1, ges översiktlig information om intervjupersonerna i form av födelseår, examensår samt år för företagsstart. En mer detaljerad översikt står att finna i bilaga 5 .

\begin{tabular}{llll}
\hline \multicolumn{2}{l}{ Tabell 6-1: Översikt tidsdimensioner } & \\
\hline Namn & Födelseår & Examensår & $\begin{array}{l}\text { Företagsstart } \\
\text { (nuvarande verksamhet) }\end{array}$ \\
\hline Karin & 1949 & 1976 & 2002 \\
Beatrice & 1951 & 1989 & 1995 \\
Christina & 1956 & 1987 & 2005 \\
Eva & 1957 & 1981 & 2001 \\
Annika & 1958 & 1984 & 1996 \\
Rebecca & 1958 & 1983 & 2006 \\
Sandra & 1961 & $1988 / 89$ & 1994 \\
Susanna & 1966 & 1995 & 2007 (1985) \\
Anja & 1967 & 2000 & 2011 \\
Lena & 1972 & $2005 / 06$ & 2009 \\
\hline
\end{tabular}

\footnotetext{
38 Susanna gick in i sin makes företag som delägare år 2007 i samband med att det omvandlades till aktiebolag. Grundstommen för företaget grundade dock maken år 1985, innan paret träffats.
} 
Kapitel 6: Livet som veterinär och företagare

\section{Företagandets frihet}

En fördel som ofta lyfts fram av intervjupersonerna med att vara egen företagare är friheten och möjligheten att själv bestämma över sin arbetssituation. Det finns givetvis också nackdelar med att vara egen företagare i det hänseendet. Rebecca berättar om sin syn på detta:

Det har ju sina för- och nackdelar att vara helt själv. Nackdelen är att det är lite mer nischat. Folk kommer till mig. Jag säljer mig själv. Då är det inte så lätt att skaffa en vikarie. Okej om de kommer med ett akutfall då kanske man bara är glad att man får komma någonstans. Men det är lite så där att det blir väldigt lite semester och bortavaro.

Rebecca är ensam veterinär på sin klinik och är därmed den som håller verksamheten igång. Då verksamheten är beroende av henne är det svårt att skaffa vikarie. Många djurägare åker flera mil för att få träffa just henne. Detta ställs mot det faktum att Rebecca värnar om sin hälsa. Erfarenheter av kollegor som gått in i väggen har föranlett henne att vara ledig på onsdagar och helger. Själv ser hon det som ett sätt att kompensera generellt korta semestrar. Annika har en liknande upplevelse:

Men samtidigt så är det ju så att jag ställer ju upp på mina djurägare dygnet runt. Det är inte så många som gör det faktiskt. Men det är ju lite granna så som jag har nischat mig. Jag har ju inte fullt hela dagarna utan nu jobbar jag i princip varannan dag.

Annika talar också om att ha nischat sig som tillgänglig. Även hon är ensam veterinär på kliniken och förhållandet till djurägarna tycks på så sätt bli mer personligt precis som för Rebecca. Annika är vid tillfället för intervjun sjukskriven på 50 procent och arbetar därmed bara vissa dagar i veckan. Susanna menar att friheten inte handlar så mycket om fritid som om friheten att styra själv:

Men en stor fördel tycker jag är att man kan styra sin vardag väldigt mycket själv. Särskilt när man har fått barn så är det ju otroligt värdefullt. Man styr mer över sina tider själv. Det är jätteskönt. Den här friheten som man har.

Lena, som än så länge driver sitt företag på 20 procent och har en tjänst hos en statlig myndighet på 80 procent, berättar om sitt företagande:

Man sitter ju på kvällar och helger. Ringer någon så åker jag ut och hjälper. Det är på väldigt olika tider på helgerna, förstås när jag kan. Det är väldigt uppskattat att jag kan komma ut sent en kväll eller på juldagen. Det gör jag ju nu för att hålla det här och vara tillgänglig. Det har jag ingenting emot för jag gillar att jobba praktiskt och jag saknar det. Men jag tycker att 
det är på en bra nivå nu. Jag har min hemsida men jag har inte annonserat någonting i övrigt och det sprids från person till person.

För Lena är tillgängligheten viktig. Hon vill inte gärna säga nej till kunder och menar att det är väldigt uppskattat när hon kan komma sent en kväll (Lena arbetar som ambulerande veterinär). Hon driver inte sitt företag på heltid ännu men uppskattar möjligheten att få jobba praktiskt. Lena jämför med sin tidigare situation som anställd veterinär och menar att det är vardag för henne att jobba mycket. Skillnaden i arbetstid för Lena är snarare att hon numera själv bestämmer över sin tid. Samtidigt uttrycker hon en oro över att för många ska upptäcka hennes företag så att hon ska få för mycket att göra. Roten till denna oro är svårigheten att säga nej till kunder. Annika menar att företagandet måste värderas utifrån den frihet som det ger:

Annars skulle jag ju inte ha fortsatt under alla de här åren. Jag är inte ett dugg intresserad av ... det är en del som har frågat om jag inte kan komma och jobba lite här och där. Nej dels släpper jag ju mina djurägare lite granna då. Jag har det bra på det här viset och jag vill inte ha en ändring där. Jag kan inte tänka mig att gå tillbaka till någon slags anställningsform. Men det är ju det som är fördelen med företagandet att man har sin lilla frihet även om den kan vara ganska inskränkt ibland.

Att gå tillbaka till någon form av anställning, ens på deltid är otänkbart för Annika. Hon framhåller sin frihet som en stor anledning men lägger även till lojaliteten till djurägarna. Hon är dock tydlig med att även friheten har sina begränsningar. Annika har sitt företag i anslutning till hemmet och det påverkar arbetstiden och friheten:

Det blir lite speciellt när man har det hemma om man säger så. Det jobbiga är att man har svårt att sätta sig ned och göra ingenting eller sätta sig och läsa. Jag har ju alltid något att pyssla med.

Motsägelsen av att hylla friheten samtidigt som man lever för sitt arbete - antingen det gäller önskan om tillgänglighet eller därför att det som hela tiden finns där - är intressant. Det intervjupersonerna ser som en fördel med att vara företagare försakas till förmån för arbetet:

Det är väl så att om jag ska vara ledig, riktigt ledig ... det känner jag mig inte om jag inte åker härifrån. Det känns som att då får man åka bort. För det är alltid någon som; "kan inte du titta på min häst", "jag brukar ju aldrig ringa dig men min hund det är så här och så här", "jag förstår att du är ledig men”. Jag är så där att jag inte kan säga nej. (...) Då får jag dåligt samvete. (...) Det är inte bara under samtalet i två minuter utan det är en process på 45 minuter medan jag har dåligt samvete och mår dåligt. Jag fortsätter att fundera på det där och jag tänker "nästa gång jag ser den 
Kapitel 6: Livet som veterinär och företagare

[djurägaren] måste jag fråga hur det gick". Så jag försöker att inte vara anträffbar när jag är ledig. Men det är inte helt lätt alla gånger.

Beatrice och Lena delar detta dilemma med svårigheten att säga nej. Beatrice beskriver en efterföljande process då hon har sagt nej som tar mycket energi. Annika menar att hon genom åren har lärt sig att säga nej:

Jag kan ju säga nej nu, det kunde jag inte förut. Nu kan jag välja. Så att det har jag ju blivit lite bättre på nu men på djursjukhuset fick jag ju inte säga nej. Det var ju bara att ta in. Är det så att jag inte trivs med en djurägare här, så kan man ju på något sätt krångla sig ur det. Oftast i alla fall.

Som anställd fick Annika inte säga nej men nu kan hon välja själv. Hon kan välja att säga ja eller nej till arbetstillfällen men i vissa fall även till djurägare som hon inte trivs med. Det finns möjligheter i företagandet som inte fanns när hon var anställd. Annika väljer att nyttja dessa möjligheter. Som vi dock tidigare sett är det svårare för Annika att dra en gräns mellan arbetstid och fritid, mycket på grund av att hon har sin verksamhet i hemmet. Karin är liksom Lena ambulerande men med fokus på häst och seminverksamhet samt frysning av embryon:

Det är på ett sätt mycket lättare att bara glida in som veterinär när man är ambulerande. (...) Fast det är mycket mer bilkörning. Jag hade fem mil emellan de här stationerna; en i Kolmården och en på Vikbolandet, så jag åkte färja över Bråviken. Det var jättevackert. Fem minuter fick man där. Så det är mycket lättare att vara ambulerande än att ha alltihop liksom.

Intervjupersonerna kopplar samman företagande med frihet. En frihet att bestämma över sin arbetssituation och arbetstid. Det finns de som värnar om lediga dagar medan andra tycks ha ett närmast personligt förhållande till "sina" djurägare. Ett förhållande som bygger på att de ska vara tillgängliga hela tiden. Friheten som kommer med företagande mynnar till viss del ut i en frihet att arbeta mer snarare än mindre. Konsten att kunna säga nej framhålls samtidigt som viktig såväl som svår. Några intervjupersoner har lättare att bemästra denna konst än andra. Företagandets omständigheter i fråga om lokalitet - i hemmet, utanför hemmet eller ambulerande tycks också inverka på möjligheterna till den frihet som intervjupersonerna hyllar. 


\section{Ambitioner}

Att företagande och profession för intervjupersonerna är intrikat sammantvinnade råder det inte något tvivel om. Utgångspunkten för företagandet är professionen. Sandra reflekterar kring sitt företagande och menar att hon är nöjd som det är:

Det är som jag säger till alla som ringer och försöker sälja annonser - jag är ändå så pass priviligierad att jag har så mycket att göra som jag vill ha. Så jag annonserar inte och jag klarar mig. Sedan är jag inte rik, jag tjänar inga miljoner och jag köper ingen dyr bil och jag kan inte utvidga, jag kan inte anställa någon utan det går precis så här [visar jämvikt med handen]. Som jag sa det skulle ju inte gå om jag inte hade en till i familjen som har en inkomst. Men samtidigt har jag ju kommit så pass långt $i$ livet att jag inser att jag inte kommer att göra någon stor karriär. Jag kommer inte starta djursjukhuset och doktorera eller något sådant. Utan nu har man landat på något sätt i det där att ha det bra. Man träffar sina kollegor och de stressar ihjäl sig och mår dåligt och de utvidgar och de ska tjäna pengar - de jagar och jagar och jagar. Får jag ett återbud på eftermiddagen så tänker jag att "oh vad skönt då kan jag åka och rida i stället". Det har jag börjat inse att det är ju ett jätteprivilegium.

Sandra har nått en jämvikt i sitt företagande som hon är bekväm med. Hon väger möjligheten att tjäna miljoner mot den stress som hon menar finns bland hennes tidigare kollegor. Att kunna ta ett återbud med jämnmod och se det som en chans att kunna åka iväg och rida istället är en alternativ rikedom. Samtidigt varnar hon för en syn på företagande som en dans på rosor, där flexibilitet oreflekterat tolkas som mycket ledig tid. Eva har under sitt arbetsliv pendlat mellan att vara anställd och företagare. Hon gick under 1990-talet från företagande till att vara anställd vid en hästklinik då hon ville utvecklas som veterinär:

Det hade ingenting med firma eller anställda att göra utan det hade att göra med att jag ville göra andra arbetsuppgifter och lära mig lite mera. Jobba lite mer med kirurgi - då måste man kunna söva och det kan man inte göra ensam ute i fältet utan det måste man göra på en klinik.

Eva återgick sedermera till att vara företagare år 2001, även denna gång med en önskan om att förnya sig. I ett eget mindre företag kan Eva sköta sig själv och göra det hon är intresserad av men kirurgi är samtidigt inte möjligt då det ställer stora krav på verksamheten, inte minst i form av pengar. Ett utlopp för intresset för kirurgi finns då snarare i en anställning. Att pendla mellan företagande och anställning har i Evas fall varit ett sätt att få det bästa av två världar. 
Rebecca är i likhet med Sandra ovan nöjd med sitt företagande som det är. Ett behov av att utvecklas kopplar hon snarare till professionen. Förhoppningen är att ständigt utvecklas som veterinär:

Jag vill nog ständigt lära mig mer. Inte stagnera. Jag hoppas ju att kunna lägga lite mer tid på att söka mer kunskap. Det finns ju så mycket och det är lätt att söka kunskap idag. Jämfört med förut att man fick ha hyllmeter med böcker. Jag vill utvecklas ständigt och sen själva företagandet det är rätt så bra som det är.

I samtalen med intervjupersonerna skildras olika ambitioner för företagande och profession och även strategier för att uppnå dem. Rebecca och Eva uttrycker ovan en ambition om att fortsätta utvecklas och Eva ger exempel på hur hon har agerat för att förnya sig med jämna mellanrum. Ambitionerna kan också, som i Sandras fall, handla om att hitta en jämvikt i livet.

Lena är ambulerande veterinär i likhet med Karin men med fokus på sällskapsdjur istället för häst och där Karin har hela Sverige som sitt arbetsfält håller sig Lena till sitt hemlän. Lena åker hem till djurägaren och utför behandlingen där. För henne har företagandet öppnat dörrar för professionella strävanden som hon inte kunnat få utlopp för som anställd:

Men det är affärsidén och det är också det som jag har fått flest frågor om, kan jag säga.

- Kan du komma hem och hjälpa oss hemma för vi har en jätterädd tax som blir åksjuk?

- Vi har en hund som inte klarar av att åka in [till en djurklinik].

- Vi orkar inte åka in själva för att vi blir så ledsna när vi kommer dit och ska avliva honom.

Då när jag jobbade på klinikerna så var jag ju tvungen att svara nej på de där frågorna och säga att det inte är någonting som vi utför. Det kändes lite jobbigt eller tråkigt, för att jag kunde definitivt tänka mig att göra så. Så det är en del utav det hela.

Rebecca har en liten djurklinik på landet men med en affärsidé som påminner om Lenas. Även för Rebecca har företagandet inneburit en möjlighet att följa sitt professionella hjärta:

Min slogan är djursjukvård i hemmamiljö. Faktum är att det är många hundar som kommer hit som är väldigt rädda för veterinärer och de [hundarna] fattar inte att det här är en klinik. Det som inte fungerar annars 
fungerar här. Sen är det ju också att man är lite lyhörd för, om de [djurägarna] exempelvis säger att:

- Jag har en hanhund som blir väldigt stressad av andra!

- Ja, men vad bra då ser vi till att vi bokar det när det är lugnt, typ första patienten efter lunch eller sista innan, svarar jag då.

Det vet jag att det uppskattar folk att dom får komma med egna synpunkter. För jag menar åker man till ett djursjukhus som tar emot kanske 15000 patienter om året så finns det inte mycket utrymme för sådant.

Både Lena och Rebecca tar chansen att anpassa sina verksamheter och sin professionella utövning till omständigheter och aktiviteter som de förut varit förhindrade från på ett eller annat sätt. De tar båda tillfället $\mathrm{i}$ akt att agera på de brister de upplevt vid tidigare arbetsplatser. Jourtid lyfts av flera intervjupersoner fram som ett problem i länet. Att kunna erbjuda exempelvis kennelägare beredskap vid valpning är en ambition som Lena har i sitt framtida företagande. Tidsaspekten är även del i Anjas affärsidé:

Det som jag tänker konkurrera med det är inte så mycket priser. För jag måste ta rimliga priser. Utan det är tider, det är flexibiliteten och det är jourmöjligheten. Eftersom jag inte har familj så har jag inga stora krav på mig hemifrån. Så då kan jag ställa upp lite när som helst, jag kan köra kvällsmottagningar, jag kan köra hembesök och på helger.

Intervjupersonerna uttrycker olika slags ambitioner, kopplade till det egna lärandet, jämvikt i livet eller helt enkelt i strävan att åtgärda olika brister de identifierat. Ambitionerna är till stor del grundade i professionen men utloppet för dem återfinns inte sällan i företagandet. Eva pendlar bokstavligt talat mellan anställning och företagande för att få ut det bästa av professionen.

\section{Synen på framgång}

I närmare diskussioner med intervjupersonerna om hur de ser på sina företag och vad de tycker är ett framgångsrikt företag uppkommer flera viktiga faktorer, inte minst ekonomi. Karin är ambulerande veterinär med inriktning mot häst. Hon är den äldsta och mest erfarna av veterinärerna sett till examensår (1976):

Det är egentligen att man har gott renommé och kunskap, erfarenhet och omdöme. Så att man får nöjda djurägare. Det är väl det egentligen. Sen ska det ju gå runt med. Det är väl det. Ja kompetens, erfarenhet och gott 
Kapitel 6: Livet som veterinär och företagare

omdöme. Det är det som krävs tror jag och det utvecklar man i bästa fall. Och sen att ha nöjda djurägare då.

Karin nämner en tillräcklig ekonomi som ett kriterium för ett framgångsrikt företagande. Det nämns dock mer i förbifarten. Flera av de faktorer som Karin lyfter fram är kopplade till professionen. Gott renommé och nöjda djurägare hänger samman och är viktiga förutsättningar för Karin som företagare men också som veterinär. Företaget har under några år legat i träda och vid tiden för intervjun har Karin nyligen dragit igång verksamheten igen och går än så länge precis runt. Karin är dock en av få personer i Sverige som har inriktning mot embryotransfer och hon litar till sin kunskap och erfarenhet som en god grund för företaget.

Anja skiljer sig från övriga intervjupersoner i sin beskrivning av ett framgångsrikt företagande. Hon betonar det som hon på andra arbetsplatser ofta har saknat; kontroll. Behovet och strävan efter den kontroll som hon tidigare saknat för Anja över i sin syn på vad som är ett framgångsrikt företagande:

Jag tror att just det här med kontroll, när man har kontroll över vardagen och kontroll över vad som händer i företaget. Att alla bitar faller på plats och att man kan etablera bra arbetsrutiner, bra förhållanden med personalen och att man känner att man har kontroll på läget. Att det är någon som sköter fakturorna, någon som sköter beställningar i butiken och det är någon som sköter det veterinärmedicinska. Man kan organisera jobbet men ändå känna att det har kontroll över mig. Men det är ju jag som ska ha kontroll över jobbet. Alldeles för mycket har det varit tvärtom.

Anja har vid flera tillfällen återkommit till ämnet kontroll. Hon har beskrivit ett antal situationer i likhet med ovan där hon inte har känt att hon haft kontroll. Detta behov vidgas, i tal om framgång, till att även inkludera företagandet.

Flera intervjupersoner kopplar diskussionen om ett framgångsrikt företagande till det egna företagets förutsättningar. Christina, med den stora hästkliniken, tar dock ett större grepp på det hela och menar att allt startar med en idé:

Framgångsrikt företagande, det är väl om en person har en egen idé. Och startar upp med det och förmår att vidareutveckla den här idén och får skapa arbetstillfällen åt många människor och sen att vidareutveckla den verksamheten så att den genererar arbetstillfällen. Alltså något positivt till både samhälle och många människor. Och genererar en känsla av tillfredsställelse för den personen som driver företaget. Så att man lever sin dröm på något sätt. Och ändå kan få det positivt för många människor. Inte i första hand göra det av ekonomisk vinning. Men genererar man pengar, så genererar det också möjligheter att göra nytta i samhället. 
Christina erbjuder en syn på företagande som till viss del är frikopplad från hennes egen situation. Hon poängterar snarare företagande som att vara en del av, och ge tillbaka till, samhället exempelvis i form av arbetstillfällen. Att utveckla en idé, leva sin dröm och till viss del generera pengar är tecken på ett lyckat företagande menar hon.

Lena talar passionerat om sitt företagande, något som skiljer ut henne från övriga intervjupersoner. Lena är, icke att förglömma, den av intervjupersonerna som än så länge inte driver sitt företag på 100 procent:

Det största skälet är att jag vill framåt, jag vill skapa någonting, jag vill bli bra på någonting och jag vill stå för det också. Jag vill ta smällen men jag vill även få berömmet. För annars när man är anställd så har man sin lön och man kan få löneförhöjning om man är bra men äran är det någon annan som får ta åt sig. I och för sig också smällarna då, men det känner jag att de kan jag ta. Jag vill skapa något eget som jag kan vara stolt över och som kan gagna mig.

Detta kan ställas i kontrast till Eva, med sin hästklinik mitt i smeten, som är nöjd med sitt företag som det är:

Jag tycker att det här är en rätt så lagom nivå. (...) Jag är inte så road av att hålla på med papper och med anställda. Så jag är ingen sådan där som vill ha ett imperium av kliniker och jag är inte särskilt sugen på att anställa några fler människor i verksamheten heller. Jag har full styrning till vad jag orkar att göra själv, så jag behöver inte öka på kundantalet. Det är rätt lagom nivå och jag trivs med det. Det kanske hade varit skillnad om jag varit 40 och suttit på det här stället. Men nu har jag också insett att om jag ska ändra på någonting så blir det kanske någon annan verksamhet. Denna så som den är, den sitter rätt så bra. Den är flexibel, vi kan packa in alla grejer och åka till Frankrike och jobba om vi vill det.

Intervjupersonerna relaterar i många fall framgångsrikt företagande till sin egen situation. Det de har, om det så är stabil ekonomi, nöjda kunder eller kontroll, är också det som framhävs som viktigt. Samtliga är nöjda med sitt företagande och flera tycks ha lagom som ett slags ledord, om än implicit. Att i detta fall försöka särskilja deras syn på profession från den om företagande blir svårt då de bygger på varandra.

\section{Företaget eller professionen?}

Även om en god ekonomi ses som en av de främsta indikatorerna för ett framgångsrikt företag, så prioriteras det inte av intervjupersonerna till vilket pris som helst. Samtidigt 
som det är viktigt att företaget går runt och kanske till och med har en stabil ekonomi, finns det många sätt att tjäna pengar som inte alltid är förenliga med intervjupersonernas syn på professionalitet. Då avstår de intervjuade. I de fall då Sandra känner att hon inte kan göra ett professionellt arbete remitterar hon gärna till en kollega:

Vi är kurskamrater och det är ju helt suveränt för att hon har ju fullt upp att göra på sin klinik, vilket innebär att de [djurägarna] ju kan ringa mig och säga att hästen är halt och si och så och så kan jag åka och titta på den och så kan jag säga att - Ta din häst och åk till hästkliniken! Det är liksom aldrig mer än tre fyra mil bort. Det är ju jättebra för det är inte professionellt att stå på en lerig gårdsplan och sticka nålar i leder. Utan då är det bättre att jag tittar på det, säger om de ska vila, kanske ge medicin eller om de ska åka in mer akut och så följer dem upp där. Det är jättebra.

Att generera pengar till företaget ställs mot att upprätthålla en god professionell standard. Hellre än att tumma på standarden så remitterar Sandra till en kollega. Lena ger exempel på en alltför liberal användning av antibiotika som en enkel men oetisk väg för veterinärer att gå39:

Det är jättelätt att skriva ut antibiotika hela tiden, djuren blir ju friska oavsett om de behövde den eller inte. Man kan ju faktiskt damma på med det mesta men man har ju liksom bäddat lite för sig då. Jag försöker hålla de här etiska riktlinjerna och där ligger ju faktiskt en fara när man är helt själv och egen företagare. För man vill vara populär, man vill tjäna pengar, man vill göra bra ifrån sig och man vill få gott omdöme och att alla blir friska.

En liberal förskrivning av antibiotika skulle ur ett strikt ekonomiskt perspektiv kunna vara fördelaktigt för företaget men går emot professionens etiska riktlinjer. Lena ser detta som en potentiell fallgrop för den företagande veterinären. Önskan om ett gott rykte kan leda veterinären på avvägar menar hon.

Det tycks finnas många irrvägar mellan företagsamhet och professionalitet. De kan visa sig i liberala förskrivningar av antibiotika, annonsering av pris eller överutnyttjande av utrustning. Även i den direkta kontakten med djurägaren finns det moraliska överväganden att göra:

Alltså om vi tar den här 9-åriga tiken som får livmoderinflammation. Då måste jag analysera deras ekonomiska situation, deras vilja. De kanske har opererat en 9-årig tik tidigare som kanske levde ett halvår och de vill inte

\footnotetext{
${ }^{39}$ Riktlinjer för användning av antibiotika föreskrivs i Sveriges veterinärförbunds antibiotikapolicy.
} 
göra det igen. Eller de kanske gjorde det förr och den hunden levde 15 år och de tycker absolut att det är värt det. Det här måste du liksom lirka fram på några minuter. Jag menar för det finns ju inget rätt och fel, det är rätt att operera men jag kan inte garantera att den lever mer än ett halvår. Det är rätt att försöka med medicinsk behandling för det kan funka men då ska man veta att risken är stor att det kommer tillbaka. Det kan också vara rätt att avliva hunden om de har dåliga erfarenheter. Jag kan inte tvinga dem och vad de nu väljer ska kunden känna att jag gjorde rätt.

I scenariot som Rebecca beskriver ovan finns en rad olika aspekter att ta hänsyn till. Att ställa diagnosen på djuret är i vissa fall endast ett första steg, därefter behövs också en bedömning av djurägaren. Det som vore bäst för verksamheten ekonomiskt sett kanske inte är vad som är bäst vare sig för djuret eller djurägaren.

Sandra beskriver sin vardag och hur hon resonerar kring att vara veterinär och företagare:

I den här verksamheten är det ju operationerna som ger pengar. Då tjänar du mycket pengar på kort tid. Jag gör ju sådana här idiotsaker som att jag kan åka tre mil enkel resa och vaccinera en häst och så åker jag tillbaka igen. Då kostar det ju alltså 500 kronor att vaccinera hästen. Det är ju fullständigt vansinnigt. För sådant ska man ju inte göra. Jag gör det och det säger min man att jag inte ska. På något sätt så tycker jag att det inte ska vara dyrare. Jag vet inte varför. Det känns nästan omoraliskt att ta 500 spänn betalt bara för att jag kommer dit. (...) Sen så är det att folk är vana. Om jag skulle säga att - Ja jag kan vaccinera men det kostar 1500 spänn! gah säger de. För alla som har djur här ute har ju inte pengar.

Sandra vet med sig att det är operationer som hon tjänar bäst på i sin verksamhet. Trots det gör hon även långa resor med bil för att vaccinera en häst för 500 kronor. Ett agerande som hon själv kallar fullständigt vansinnigt samtidigt som hon menar att det känns omoraliskt att ta en inställelseavgift. 1500 kronor skulle vara ett mer skäligt pris men då skulle inte djurägarna ha råd. Hon fortsätter dock eftertänksamt:

Fast att vaccinera en häst är ju inte så viktigt egentligen. Inte som om jag hade ett lamm som brutit benet - det kanske hade känts mer motiverat. Det borde rimligtvis vara så att jag skulle kunna säga att:

- Jamen vaddå, din häst dör inte om den inte blir vaccinerad - du kan inte tävla men det är inte mitt problem!

Sandra jämför vaccineringen av en häst med ett mer akut fall som ett lamm som brutit benet. Rimligtvis borde hon kunna säga nej till att vaccinera någons häst utan problem 
då det inte handlar om någon form av lidande eller livshotande tillstånd. Ingen skulle kunna kritisera henne för att vara oprofessionell. Sandra förklarar sitt agerande:

Samtidigt så är det ju så att det här är ett samhälle - landet är landet - och det handlar ju en del om ens goda rykte. Alla känner alla här. Om någon säger att den där veterinären hon är en snobbig typ, hon sa si och hon sa så. Det sprider sig snabbt. Så att det handlar ju också om ens goodwill.

Det som tillsynes är ett oekonomiskt agerande på kort sikt visar sig i slutändan vara en fråga om att sätta företagandet främst. Att få ett rykte som snobbig skulle kunna inverka menligt på kundunderlaget på lång sikt. Utifrån detta synsätt sammanfaller till viss del profession och företagande.

Intervjupersonerna beskriver en balansgång vad gäller företagande och professionalitet. En balansgång där etiska riktlinjer ibland ställs mot ekonomiskt välstånd. Det som främjar företagandet rent ekonomiskt är inte alltid förenligt med vad som anses som professionellt och vice versa. Men ibland kan de faktiskt sammanfalla i en positiv kombination. Lena är i uppstartsfasen av sitt företagande och drivs av en strävan efter något eget. Samtidigt som hon beskriver arbetssituationen för en anställd veterinär som mycket krävande berättar hon att hon är beredd att arbeta hårt i sitt företag:

Ska jag jobba 53 timmar i sträck under en helg så ska jag banne mig göra det åt mig själv (skratt). Då ska jag bestämma det på egen hand och när jag har blivit så galen då ska jag starta eget (skratt).

Lena skrattar åt sig själv i samband med detta uttalande. Att arbeta 53 timmar i sträck ser hon som en galenskap i sig men menar också att hon hellre gör det till förmån för sitt eget företag än för någon annans. Företagandet ger henne därmed möjligheten att bestämma över sin professionsutövning.

Christina driver tillsammans med en kompanjon en hästklinik. Hon beskriver sin kompanjon som den riktiga företagare som tar hand om det administrativa medan hon får ägna sig åt att vara veterinär:

Jag var tvungen att ha någon samarbetspartner som drog den tunga biten administrativt och sen ha en tillräckligt liten verksamhet så att jag inte var tvungen att jobba hysteriskt. Det räckte med en begränsad mängd tid i början för att ändå få företaget att gå ihop sig. Vi hade en kalkyl som inte innebar att generera en jättestor vinst utan vi skulle bara gå plus minus noll.

Förbehållen för att starta företag var i Christinas fall flera. Prioritet nummer ett var dock att själv få fokusera på att vara veterinär och överlåta administrationen till någon 
annan. Den första kalkylen var medvetet försiktig då Christina inte ville överhopas av arbete. Hon tillägger:

Jag vet inte om jag är någon representativ företagare. Jag tror att veterinärer är intresserade av veterinärmedicin och att företagandet är ett bifynd.

En önskan om att "bara" få vara veterinär uttrycker även Rebecca:

Och som jag sa till min karl - Om jag bara fick vara veterinär, vad härligt det skulle vara! Men när man måste lösa en massa andra problem också. Och sen det här med att folk kör i diket och så också. Ja, då ringer jag ju i och för sig till honom [maken] så får han lösa det.

Rebecca vill helst av allt vara veterinär och ägna sig åt det. Eftersom Rebeccas klinik är belägen ute på landsbygden, kan det vid snörika vintrar bli problem för de djurägare som försöker ta sig till henne. I dessa fall hanterar dock Rebecca detta genom att ringa in sin make. Även krånglande datorer ges som exempel på sådant som Rebecca i egenskap av egen företagare behöver hantera vid sidan av att vara veterinär.

Samtidigt som Christina ovan framhåller att företagande för veterinärer snarare kommer i andra hand berättar hon med beundran i rösten om en manlig kollega i länet som inte passar in i denna bild:

Så vi har en kollega som, om jag är rätt informerad, köpte ... men han är ju man då ... Han var ju företagare och sålde det företaget och började läsa till veterinär. Sen hade han ju ganska mycket pengar efter att ha sålt det här framgångsrika företaget. När en djurklinik blev till salu så köpte han den samtidigt som han var veterinärstudent och anställde veterinärer med specialistkompetens. Det tycker jag är framgångsrikt företagande. Men då hade ju han pengarna. Han hade genererat pengar och han hade inte kompetens själv utan han köpte in den. Det kan ju jag känna att företagsbiten - att vi är lite för lite renodlade företagare, vi tvingas att bli företagare för att överleva fast vi vill egentligen hålla på med veterinärmedicin. Lite så kan jag känna. Medan han ju faktiskt är företagare rent tekniskt och så ser ju han den här lösningen och sen kan ju han skaffa sig kompetensen och gå in vart efter och lära sig av dem han har anställt. Så det var ju lite roligt.

Mannen beskrivs som en företagare i första hand som sedan utbildade sig till veterinär. Christina poängterar åter att den typiska veterinären är någon som är veterinär i första hand och företagare i andra hand. I exemplet med den manliga kollegan illustreras 
någon som sätter företagande framför profession. Christina själv, och de flesta veterinärer menar hon, prioriterar dock professionsutövningen framför företagandet.

Karin har sedan tidigare erfarenhet av företagande och har nyligen återupptagit sin verksamhet men numera som ambulerande veterinär med inriktning mot semin och embryotransfer. Hon menar att professionen möjliggör för företagande:

Yrket är ju lite så att man kan nästan sätta upp och starta upp vart som helst. Har man den traditionen med sig hemifrån så tror jag att det är lättare att kasta sig ut. Först behöver man ju skaffa sig lite erfarenhet egentligen innan man gör det.

Susanna hade ingen tidigare erfarenhet av företagande och gick in i det företag som hennes make drivit sedan många år:

Jag känner mig inte som en företagare så mycket. Faktiskt inte. Det är nog mycket det att jag har hoppat in i ett befintligt företag. Jag har inte behövt ha de här hundåren som man säger. När det är besvärligt med ekonomi och så.

Det Susanna ironiskt nog kallar hundåren, de första åren med bland annat en besvärlig ekonomisk situation, är det som hon kopplar samman med att vara företagare:

I och med att det är en veterinärverksamhet, så har ju jag ett övergripande ansvar. Om man ska vara ledig så får man ju ta in en vikarie i sådana fall och då blir det ju genast ekonomiska peakar kring det. Så jag är kvar liksom som verksamhetsansvarig [i samband med att hon är föräldraledig]. Egentligen arbetsmässigt så gör vi samma saker kan man säga. Min man har ju blivit godkänd av jordbruksverket som sådan här djurvårdspersonal som det heter nu för tiden. Och då kan jag delegera behandlingar till honom. Jag behöver inte stå och ge patienterna lugnande medel till exempel. Så på det sättet funkar det. Men det krävs att det är en veterinär som är i verksamheten för att det ska godkännas.

Susanna identifierar sig inte som företagare då hon inte var med från uppstarten. Något hon ser som ett kriterium för att få kalla sig företagare. I synen på sig själv prioriteras därmed också hennes roll som professionell framför den som företagare. Sett till företaget är dock Susanna en nyckelperson. Utan henne är verksamheten inte möjlig. På detta vis möjliggör hennes roll som professionell företagandet. Här uppstår en situation där synen på jaget går på tvärs med förutsättningarna för verksamheten. 


\section{Sammanfattning}

En aspekt som flertalet intervjupersoner lyfter fram avseende livet som veterinär och företagare är att företagande handlar om frihet. En närmare granskning av denna frihet visar dock att den på många sätt är inskränkt. Intervjupersonerna uttrycker olika slags ambitioner, kopplade till det egna lärandet, jämvikt i livet eller helt enkelt i strävan att åtgärda olika brister. Ambitionerna är till stor del grundade i professionen men utloppet för dem återfinns inte sällan i företagandet. Framgångsrikt företagande relateras i många fall till den egna situationen. Det blir tydligt att professionen ses som en stor del i vad som utgör ett framgångsrikt företagande. Samtidigt beskrivs en balansgång vad gäller företagande och professionalitet. Där det ena ibland prioriteras framför det andra. Men det finns även situationer då företagande och profession samspelar och där strävan efter det ena möjliggörs av det andra. 
Kapitel 6: Livet som veterinär och företagare 


\section{Kapitel 7}

\section{Livet som företagare och kvinna}

Ietta kapitel kommer livet som företagare och kvinna vara i fokus. Resultatet

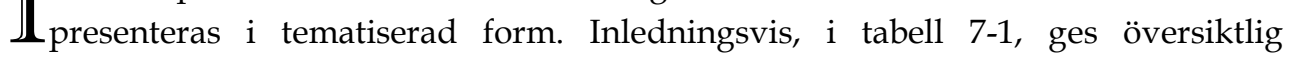
information om intervjupersonernas företagande.

\begin{tabular}{lllll}
\hline Tabell 7-1: Översikt företagande & & \\
\hline Namn & $\begin{array}{l}\text { Företagsstart } \\
\text { (nuvarande } \\
\text { verksamhet) }\end{array}$ & $\begin{array}{l}\text { Tidigare } \\
\text { erfarenheter } \\
\text { av företagande }\end{array}$ & $\begin{array}{l}\text { Summerad } \\
\text { erfarenhet i } \\
\text { år }\end{array}$ & Ägande \\
\hline Karin & 2002 & Ja & 25 & Ensam \\
Beatrice & 1995 & Inga & 17 & Ensam \\
Christina & 2005 & Till viss del & 7 & Delat \\
Eva & 2001 & Ja & 20 & Delat \\
Annika & 1996 & Inga & 16 & Ensam \\
Rebecca & 2006 & Ja & 24 & Delat \\
Sandra & 1994 & Till viss del & 18 & Ensam \\
Susanna & $2007(1985)^{40}$ & Inga & 5 & Delat \\
Anja & 2011 & Till viss del & 2 & Ensam \\
Lena & 2009 & Inga & 3 & Ensam \\
\hline
\end{tabular}

\footnotetext{
40 Susanna gick in i sin makes företag som delägare år 2007 i samband med att det omvandlades till aktiebolag. Grundstommen för företaget grundade dock maken innan paret träffats år 1985.
} 


\section{Att bli företagare}

Flera av de intervjuade veterinärerna har utöver det aktuella företaget tidigare erfarenheter av företagande. Vissa har företagande i släkten eller familjen och andra har haft företag innan nuvarande verksamhet. Christinas pappa drev företag under hennes uppväxt och hon relaterar den erfarenheten till att hon på så sätt redan från början visste att det krävdes mycket att driva ett företag. Genom att under flera år kombinera olika anställningar med verksamhet i enskild firma hade Christina egna erfarenheter av företagande redan innan den nuvarande verksamheten startades.

Jag var ju både anställd på trav och galopp-banan, vid SLU och av ATG. Jag hade även enskild firma. Jag jobbade halvtid på kliniken och ibland så kanske någon travtränare ringde och hade femton hästar han ville ha kollade. Jag hade ju inte tid, det fanns inte plats på kliniken att få in dem. Då hade vi ju förlorat den travtränaren, om inte jag hade kunnat åka ut själv. Jag kunde ju inte fakturera via kliniken för det stämde ju inte med arbetstiden så det gick inte och jag kunde ju inte köra svart (det är ju proffsfolk). De behöver kvitto och fakturor till sina hästägare. Så då hade jag ju enskild firma. Med bokföring och redovisning och allt det här, det tar ju jättelång tid. Sen hoppade jag in på jourerna åt Jordbruksverket dessutom ibland när det fattades folk på helgen. Så då jag gick jourerna också. Men som sagt jag har nog ett väldigt företagstänkande i botten och det är väl det som krävs på något vis. Men livssituationen och vad man prioriterar i livet avgör väl om man gör slag i saken.

Christina hade under en period många järn i elden. Hennes enskilda firma beskrivs som ett sätt att hantera de kunder som det inte fanns utrymme för i den dagliga verksamheten vid kliniken där hon arbetade deltid. Den bild av företagande som Christina förmedlar i ovanstående citat är att ett företag kräver mycket, inte minst i form av bokföring och redovisning. Hon reflekterar över att hon själv nog i vissa fall tänker som en företagare. Livssituation och prioriteringar i livet menar hon dock är det som är avgörande för att starta företag.

Sandra startade sin första enskilda firma långt innan hon blev veterinär, som ett sätt att försörja sig:

Under alla de här åren som jag väntade på att bli veterinär så jobbade jag som assistent hos en veterinär. Som vanligt för alla flickor som är djuroch hästintresserade så fick jag ingen lön. Men jag skötte labbet där; jag gick och utbildade mig hos en labbassistent som hade ATG kliniken där och så fanns det en del apparater som jag kunde sköta plus att jag skickade prover till sjukhuset. Så jag fick gå ut i stallarna och ta blodprover och fixa 
med dem. Då startade jag firman. Det var ett sätt att försörja mig samtidigt som jag jobbade gratis hos veterinären. (...) När jag började här var jag alltså redan enskild näringsidkare. Så jag har haft egen firma sen jag var 19 år. Fast den första var ju vilande i massor av år.

Sandras företagande började i unga år som ett sätt att försörja sig. Intresset gick i detta fall före möjligheten att få lön och företagande blev ett sätt för Sandra att lösa situationen. Med sina tidigare erfarenheter av företagande fanns det redan i Rebeccas fall en kunskapsgrund som samspelade med önskningar om ett enklare sätt att leva:

Så vi startade 1987 och jag jobbade där i 17 år. Sen började man komma till den ålder då halva arbetslivet var bakom och halva framför. Ville jag verkligen pendla och köra den här vägen? Jag satt ungefär två timmar i bilen varje dag. Jag hade önskat en egen häst sen jag var barn och först hade jag inte råd och sen bodde jag i stan och hade inte möjlighet. Nu hade jag alla möjligheter att ha en häst och så hade jag ändå inte tid för att jag bilade till och från jobbet. Det stod en ladugård tom här på gården och jag började väcka idén hos min man att vi skulle renovera den. Han trodde väl inte på den här idén riktigt men han nappade på det.

Till skillnad från Christina, Sandra och Rebecca hade Lena inga tidigare erfarenheter av företagande, varken själv eller inom familjen. Hon påpekar att många har arbetat statligt och är akademiker på ett eller annat sätt men vad gäller företagande är det hon som banar väg. Det innebär också att det inte finns någon som riktigt vet hur det går till eller hur mycket jobb det är att vara företagare:

Jag får försöka få familjen att förstå detta och jag tror att dom har köpt det för länge sen för de vet att det är så det går till. De tycker att det är jättespännande med det här, nu när de har förstått, för mina föräldrar i början blev ju väldigt:

- Åh hur ska det gå? Eget, hur ska man överleva på det?'

De har ju ett väldigt förtroende för mig som veterinär men just det där med att försörja sig till fullo på det, det är ju en annan grej. Det låter ju lite läskigare. Det tyckte nog jag också. Är det här någonting för mig och hur gör man? (skrattar).

Lena målar upp företagande som något som är svårt och en utmaning. Flera intervjupersoner, de med tidigare erfarenhet av företagande men även andra, talar snarare om företagandet som en lösning; för att kunna hinna med att ha häst, för att få en inkomst vid gratisarbete eller för att hålla kunderna glada. Beatrice var anställd som distriktsveterinär när hon fattade beslutet att starta eget. En omorganisation av DVO 
samt nya regler för lönesättning som påverkade henne negativt var faktorer som bidrog till beslutet:

Det var en massa grejer om att eftersom jag inte gjort slakteripraktik så skulle jag få sämre lön än de som var nyutexaminerade. Då surnade jag till. Då kan jag vara utan sa jag. Dessutom tyckte jag väl inte att Jordbruksverket hade framstått som någon bra arbetsgivare. (...) Det gick ju bra för jag var ju så pass etablerad här. Folk kände mig. I och med att jag var så inarbetad så blev det ingen större skillnad egentligen att starta eget.

Som vi kan ses finns det flera olika orsaker bakom intervjupersonernas val att starta företag. För Christina, Sandra och Eva var företagande tidigt en lösning på problematik kopplad till deras dåvarande arbetsplatser. Rebecca gick från ett företag till ett annat med en önskan om mer fritid medan Lena beskriver valet att starta företag som en utmaning.

\section{Anpassning}

Reflektionerna kring företagande kombineras med reflektioner kring livet i stort, där familj och relationer utgör en viktig del. I veterinärernas berättelser anpassas företagande till familjesituationen och ibland anpassas familjesituationen till företagande. Att båda dessa områden är stora och viktiga delar i veterinärernas liv är tydligt. I Annikas fall har bildandet av familj och bildandet av företag varit parallella processer:

Jag var gravid när jag sa upp mig. Egentligen väldigt vanskligt i och för sig men jag är sådan. Vad gör man när man inte har så mycket annat att välja på egentligen. Visst hade jag ju kunnat fortsätta men det var just det här med jourerna. Alltså man hade jour en gång i veckan och sen har man en helgjour en gång i månaden. Det tär och fungerade oftast inte så där jättebra. Det blev väl naturligt sen att det råkade bli hemma. Jag jobbade fram till det att jag födde men var och jobbade samma dag som jag kom hem. Jag tog ju helt enkelt med honom. Jag hade börjat lite smått på kvällarna, men det här var ju inte konkurrerande verksamhet till dem [djurkliniken] så det var ju inga problem att göra det. Så det var ett bra sätt att arbeta upp det på då. Sen hade jag som tur var en son som var fullt frisk, han var väldigt regelbunden. Det händer ju ibland att jag gör lite hembesök, det är inte så där jättevanligt men. Ibland kan de [djurägarna] säga; - Det var ju då när du precis fått barn då som du var här! 
På väg bort från en arbetssituation som Annika upplevde som ickefungerande valde hon att kombinera företagandet med att bli mamma. Företaget var till viss del redan upparbetat. Sandra hade under en period arbetat som djursjukvårdslärare dagtid och som veterinär på kvällstid men längtade tillbaka till arbetet som veterinär. Att starta företag var ett sätt att få bli veterinär på heltid igen.

Det var väl mest av praktiska skäl jag började fundera på att starta eget tror jag. Jag ville ju inte jobba som lärare, jag var ju veterinär. Jag hade folk som kom till mig, jag hade ju en liten mottagning med ett rum i källaren, och den växte mer och mer och till slut var det ohållbart att ha två jobb plus småbarn. Det sprider sig ju alltid mer eller mindre. Jag hade inte någonstans som jag kunde jobba, och det fanns inte utrymme för mig på distriktet här för de (särskilt en) ville inte ha mig. Då såg jag det som ett alternativ och det där växte ju mer och mer. Jag hade nog inte klarat det från början om jag inte hade haft en man som också tjänade pengar. Även om han till en början ... Det var ganska bråkigt. För han tyckte att om jag ändå hade mottagningen hemma i källaren så behövde jag ju inte ha barnomsorg. För jag var ju ändå hemma. Så smart. (Skrattar). Jag kan säkert stå och göra kejsarsnitt med en skrikande ett-åring vid fötterna. Faktum är att det hände men då fick ju djurägaren vara barnvakt medan jag opererade.

Sandra beskriver sin tillvaro som företagare samtidigt som hon relaterar till sin familj. Att ha mottagningen i källaren var på många sätt en utmaning. Företagandet och familjesituationen influerade varandra. Susanna funderar på om det är någon skillnad att vara företagare som kvinna eller man:

Att vara företagare som kvinna eller man det tror jag inte spelar någon roll egentligen. Det ska ju inte det i alla fall. Kvinnorna är ju hemma mer med barnen. Det är ju så. I början har man ju inte så mycket att välja på när det ska matas. Om man nu då inte väljer att använda flaskmatning från början. Men de flesta vill ju inte göra det. Så det är väl det som styr lite kanske. Just som egen företagare kan man ju inte stänga i tre månader och sen tro att man bara kan öppna igen och köra på som vanligt. Jag menar man måste ju vårda sin kundkrets. Det kan kanske också vara en förklaring till att det är många män som står som företagare. Det är ju alltid sådant som man funderar på.

I ovanstående citat går Susanna från att säga att kön inte har betydelse till att säga att det $i$ alla fall inte borde ha betydelse. Till detta läggs förbehållet om reproduktion och kvinnors ansvar. När det ansvaret kopplas samman med företagandets upplevda förutsättningar kring ledighet, kommer Susanna fram till att det kan vara en förklaring 
till att det är många män som är företagare. Lena kopplar å sin sida ihop kön med tidigare erfarenhet av företagande respektive osäkerhet:

Jag har funderat på varför det är så många fler män som startar veterinärkliniker. För när man tittar på hur det ser ut där så är det många män som är chefer och företagare för djursjukhus och veterinärkliniker och det är klart att det finns tjejer också, för det finns så få män i den här branschen. Men de är ändå överrepresenterade [män som chefer och företagare]. Jag vet inte hur mycket man ska lägga in där men jag tänker ju själv att det är ett steg att ta och jag vet inte om det är för att jag inte har någon tradition i familjen då med företagare, för hade jag det så kanske jag skulle kasta mig ut lite mera hejdlöst, men man tänker hela tiden - Åh, kommer det här att lyckas, hur ska jag börja, hur stor ska jag bli, ska jag investera i det här och det här, hur ska jag dra igång och hur ska jag då försörja mig?

Lena menar att män är överrepresenterade som chefer och företagare inom veterinärprofessionen samtidigt som det finns fler kvinnor än män i yrket. Benämningen av könen, som tjejer respektive män, ger en bild av skilda generationer där männen är de äldre, något som intervjupersonerna förknippar med erfarenhet och auktoritet samtidigt som tjejerna är unga, det vill säga oerfarna och osäkra.

Företagandet kombineras ofta med någon sorts familjeliv. Flera av intervjupersonerna lyfter fram just den kombinationen när de talar om sitt företagande. Ibland tar de anpassningar intervjupersonerna gör utgångspunkt i familjen och ibland i företagandet. I diskussioner om kvinnors och mäns förutsättningar för företagandet anger några inledningsvis en visshet om att det inte är någon skillnad. Susanna och Lena landar dock i att det kanske är så att män främst är företagare och kvinnor främst är mammor.

\section{Synen på företagande}

Intervjupersonerna ser företaget - såväl själva handlingen som verksamheten - med tidvis kritiska ögon. Tveksamheter och funderingar ger en bild av företagande som en komplicerad handling med mycket krav och regler: Christina skulle, ur ett rent ekonomiskt perspektiv, kunna ses som den som är mest framgångsrik bland intervjupersonerna:

Jag vet inte om vi är något typiskt företag direkt, jag tror inte det. Jag vet inte om det finns några typiska företag. Det finns väl olika lösningar på allt eller hur? Det är ju det som är charmen med det. Det utvecklas ju 
under resans gång. Alltså det händer saker och även om man inte är helt passiv i den här beslutsprocessen så glider man delvis med och delvis påverkar man tror jag.

Vad Christina bedömer vara ett typiskt företag är oklart. Hon är inte ens själv säker på att det finns några typiska företag. Hon menar att det är utvecklingen under resans gång som är det charmiga med företagande. Det finns ett ge och ta i utvecklingen där företagaren ibland bara kan följa med processen och ibland har möjlighet att påverka. Christina liknar på så sätt företagande med livet i stort, något som endast delvis kan styras.

Att gå in i ett redan existerande företag har inverkat på hur Susanna ser sig själv som företagare:

Det är väl det om man ska tänka på mig som företagare. Jag har egentligen bara gått in i ett etablerat företag, så jag har ju ingen erfarenhet av att starta ett företag. Jag är ju del i det men det är min man som sköter det mesta, i alla fall det här med ekonomi och så. Men vi fattar beslut tillsammans det gör vi ju. Men just pappersarbetet det sköter han. Det är enklast om en gör det kanske. Man hinner ju inte med när man har barn och så. Då måste man ju ta tid till annat också.

För Susanna är tillsynes att starta företag detsamma som ett klartecken för att få kalla sig själv företagare. Trots flera år som delägare och som delaktig i alla beslut som fattas ser hon fortfarande inte sig själv som en företagare. Susanna målar en bild av en företagare som någon som är med från företagets start och som hanterar papper och ekonomi. Lena lägger snarare tonvikt vid företagsformen:

Jag kände att jag ville smyga igång med enskild firma och då när jag startade, i augusti 2009, då var det fortfarande 100000 som insats till ett aktiebolag och det kändes som att det blev jättestort. Så jag tänkte att, nämen alltså är det så krångligt att omforma det här att jag verkligen måste starta ett aktiebolag? Jag vet ju inte riktigt hur många år som jag ska köra i den här lite mindre skalan. Det var kanske ett sätt att lura sig själv på något sätt genom att säga - Ja, så mycket företagare är jag inte! (skrattar) Jag startar bara lite grann. Så jag skulle nog säga att det inte är ett lika stort steg att ta.

Lena skämtar om att valet att smyga igång med enskild firma inte kändes som ett lika stort åtagande. Upplevelsen var att enskild firma inte på samma sätt som aktiebolag basunerade ut att hon var företagare. Att vara försiktig i sitt företagande är något som även Annika relaterar till: 
Jag har tagit det väldigt försiktigt just med tanke på mig själv och dels med tanke på att det ligger här ute på landet. Så jag har ju aldrig tagit några lån utan jag har tagit det lite pö om pö. Det är väl med tanke på övriga. Men nu spelar det ju ingen stor roll. Om man tänker på lönen så har jag ju aldrig haft det särskilt bra. Jag sitter som ett kassabiträde ungefär i lön. Men sen jobbar jag ju inte så mycket. Jag jobbar ju inte 100 procent, det gör jag inte.

Annika har varit försiktig med att ta lån för sin verksamhet, istället har hon låtit den utvecklas över tid. Försiktigheten tillskriver hon hänsynen till sig själv, till lokaliteten samt till övriga familjemedlemmar. Hon jämför sin lön med ett kassabiträdes. Det är dock inte en fulltidslön som tas ut poängterar hon.

Christina har innan uppstarten av nuvarande verksamhet varit involverad i flera projekt för att starta en hästklinik men det har gång på gång runnit ut i sanden av olika anledningar. I sin nuvarande verksamhet är hon delägare tillsammans med en man som hon kallar för en "riktig företagare":

Så jag behöver ju bara vara veterinär. Så frågan är om jag är riktigt lämplig för det här. Jag slapp ju hela den här företagsbiten och först tänkte jag; vad är haken? Undrar varför han ska bygga en klinik åt mig? Men det är klart att han behöll ju gårdens status och han har som hobby att driva företag. Det var bara så. Han tyckte att det lät som att det varit lite jobbigt för mig med allt det här som hade varit. Det var ju bättre ... han hade ju en massa hästar så då var det ju bättre att ha veterinären på gården. Jag tänker som en företagare och det har jag alltid gjort. Och just därför har jag heller inte startat eget. Därför att jag visste ju att det inte skulle gå med den livssituation jag hade. Jag kan inte både ta hand om gamla sjuka föräldrar och vara ensamstående med barn och slåss mot Jordbruksverket som då höll på och byggde klinik här. Det var ju dömt att misslyckas. De hade ju krossat mig med tumnageln.

Christina ifrågasätter i och med detta upplägg om hon ens är lämplig för att delta i studien. Det dröjer dock inte lång tid innan Christina påpekar att hon tänker som en företagare. Hon förklarar att det också var det som gjorde att hon inte startade eget tidigare. Med en livssituation som inbegrep flera hinder för företagande menar Christina att valet att inte starta var det som bekräftade att hon tänkte som en företagare. På denna linje fortsätter hon när hon berättar om sin kompanjon:

Han är så driftig - han är ju visionär. Han sa det: - Det är nog bra, för med dig är det som att släpa en stor tiger i koppel som det blir jättestora släpspår efter, det går ju inte att göra någonting! Men då sa jag att vi sparade ju en miljon där och en där. Men hade det inte varit för honom 
med hans visioner och drivkraft ... skulle alla vara som jag då blir det ju ingenting. Det funkar liksom inte. Så vi kompletterar nog varandra rätt så bra. Han bara rusar på och jag bara säger: - Det där går inte! Alltså jag har nog mycket företagartänkande i mig egentligen.

Christina säger att det aldrig skulle bli något om alla var som hon samtidigt som hon framhåller att förnuftet i olika situationer är ett utslag för hennes egenskap att tänka som en företagare. Beatrice reflekterar kring veterinärt företagande som företeelse:

Men det är ju så där att det är ju precis som i företagsvärlden i övrigt. Man köper upp, någon köper upp och lägger ned för att slippa konkurrens och så. Det är sådant där som en annan inte riktigt förstår sig på.

Företagandet $\mathrm{i}$ veterinärsektorn är precis som vilket företagande som helst menar hon. Även här görs till exempel uppköp för att eliminera konkurrens. Företagsvärlden och då även företagandet i veterinärsektorn skildras i och med Beatrice sista kommentar som något som stundtals är svårförståeligt. Det är inte den sortens aktiviteter som Beatrice ägnar sig åt i sitt företag. Sandra som arbetar delvis ambulerande berättar om långa, kostsamma bilresor för att vaccinera en häst. Priset för vaccinationen täcker inte bensinkostnaden och hon bannar sig själv för att hon inte tar ett högre pris:

Ja, det skulle jag ju kunna säga att antingen så kostar det dig 1500 kronor eller också så kommer du hit med hästen. Egentligen så skulle jag ju inte förlora något på att förlora den kunden för den ger ju inga pengar. Men det är något slags moral tror jag. Som man inte ska ha om man ska tjäna pengar. Man får inte ha moral om man ska vara affärskvinna eller affärsman.

Det som hindrar Sandra från att höja priset är moral menar hon. En företeelse som inte går ihop med att tjäna pengar. Sandra menar att hon i och med sin moral inte passar som affärskvinna.

\section{Sammanfattning}

Intervjupersonerna har en varierande grad av tidigare erfarenheter av företagande. Några är uppvuxna med företagande föräldrar. Andra har drivit företag tidigare medan några är helt nya på området. I flera av intervjupersonernas reflektioner kring erfarenheter formuleras företagande som krävande. För flera av intervjupersonerna har företagande varit en lösning. Det har varit ett sätt att komma ifrån diskriminerande arbetsplatser eller helt enkelt ett sätt att försörja sig. 
Kapitel 7: Livet som företagare och kvinna

I intervjupersonernas beskrivningar av företagande framställs det som en pusselbit jämte andra i livet. Företagandet anpassas till familjesituation och vice versa. Professionen är en stor del i företagandet. Flera av intervjupersonerna ger uttryck för tveksamhet inför den egna statusen som företagare. En beskriver sig som otypisk företagare och en som företagare endast till viss del. Andra menar att det inte är någon skillnad på kvinnors och mäns företagande. Eller att det i alla fall inte borde vara det. 


\section{Kapitel 8}

\section{Livet som veterinär och kvinna}

I

detta kapitel kommer kombinationen av profession och genus att vara huvudtemat. Resultatet för detta huvudtema presenteras i tematiserad form. Inledningsvis, i tabell 8-1, ges översiktlig information om intervjupersonerna med fokus på profession i form av examensår, verksamhetens lokalitet samt inriktning vad gäller djurslag.

\begin{tabular}{lllll}
\hline \multicolumn{4}{l}{ Tabell 8-1: Översikt professionsutövning } & \\
\hline Namn & Födelseår & Examensår & Lokalitet $^{41}$ & Djurslag42 \\
\hline Karin & 1949 & 1976 & Ambulerande ${ }^{43}$ & Häst \\
Beatrice & 1951 & 1989 & Stad & Alla \\
Christina & 1956 & 1987 & Landsbygd & Häst \\
Eva & 1957 & 1981 & Landsbygd & Häst \\
Annika & 1958 & 1984 & Landsbygd & Sällskapsdjur \\
Rebecca & 1958 & 1983 & Landsbygd & Sällskapsdjur \\
Sandra & 1961 & $1988 / 89$ & Landsbygd & Sällskapsdjur, Häst \\
Susanna & 1966 & 1995 & Landsbygd & Häst \\
Anja & 1967 & 2000 & Landsbygd & Alla \\
Lena & 1972 & $2005 / 06$ & Ambulerande & Sällskapsdjur \\
\hline
\end{tabular}

41 Indelningen i stad respektive landsbygd bygger på en definition i kapitel 2.

42 Alla djurslag innefattar lantbruksdjur, sällskapsdjur samt häst. Sällskapsdjur står främst för hund och katt men även mindre djur.

43 Ambulerande innebär att veterinären tar verksamheten till kunden istället för att ha egna lokaler dit kunden kan komma. 


\section{En profession i förändring}

Det sägs att det enda vi kan vara säkra på är att allting förändras. Förändringen kan vara liten eller stor, snabb eller långsam. Veterinärprofessionen har genomgått och genomgår fortsatt förändringar. Eva beskriver sin första sommar som veterinär, som ett närmast nostalgiskt minne av fornstora dagar.

Det har ju ändrats jättemycket från när jag började min första sommar. Det var ju helt ofattbart när man kom ut på en gård. Där stod uppdukat på ett bord med handfat och varmt vatten i en termos för tvättning. Det låg en ny tvål och det var rena handdukar upplagda och man hade sin avställningsbänk där man ställde väskan. Veterinärbesöket var någonting viktigt och dom stod nästan med mössan i handen. Många gjorde det och de var jätteartiga och vänliga och man kom ju som en liten spoling där och visste ju ingenting om kor jämfört med vad bonden själv visste. Men man hade den där magiska sprutan i handen. Om jag åker ut till ett stall nu så får jag fråga om det finns någon möjlighet att tvätta sig om händerna. Det har dom inte haft en tanke på. Så just den där respekten för själva yrkesrollen den finns ju inte längre. Däremot så kan jag ju känna mig respekterad för mina kunskaper. Men precis som man inte bugar för doktorn längre så bugar man inte för veterinären heller. Det är liksom en svunnen tid bara.

I denna redogörelse framgår en förändring i veterinärens auktoritet, något som jämförs med den av läkaren. Respekten finns fortfarande för kunskapen menar Eva men inte för yrkesrollen. Rebecca berättar även hon om en förändring, vad gäller distriktsveterinärens vardag. Dagens upplägg med stationer där distriktsveterinärerna samlas varje morgon var ännu ovanligt i början av 1980-talet. Vid sommarjobb hos en "distriktare" fick hemmet bli kontor och väntplats vid jour. Rebeccas tillbakablick till sin egen tid som sommarjobbare ställs mot ett reportage hon läst i veterinärtidningen:

Det handlade om just en sådan här studentflicka som var ute och jobbade och följde med en distriktare under en dag. Det var väldigt många samtal med stationschefen och undringar. Det fanns inte en möjlighet för oss. Vem skulle vi ha kunnat ringa? Veterinären var ju på semester, vi fick inte ens telefonnummer till honom.

Studentflickans situation med möjligheter att fråga och undra jämförs med Rebeccas egen upplevelse av att vara utelämnad till sig själv. Dåtidens frånvarande manlige auktoritet ställs mot dagens frågande studentflicka. Implicit ställer Rebecca frågan - Hur hade studentflickan hanterat Rebeccas situation? 
Minnen av gamla tider och egna upplevelser ställs gång på gång mot funderingar om den nya generationen verkligen har det som krävs. Dagens veterinärstudenter framställs som unga (direkt från gymnasiet) och ofta utan vare sig arbets- eller livserfarenheter. Risken att fel personer kommer in på veterinärutbildningen är ett återkommande ämne i de intervjuade veterinärernas berättelser. Så även hos Eva:

Av dom 100 som kommer in så kanske det inte är mer än 70 som är kvar när man kommer till de kliniska ämnena. För de är ju helt fel, de har ingen aning om vad veterinäryrket går ut på. De tycker det är äckligt att skära i döda djur. Det luktar illa och det är tungt och det är bråkigt och de har ju liksom ingen aning om hur det är att hålla på med djur. De har haft en hund eller en hamster och så har de femma i betyget och så är veterinär ett fint yrke.

Karin menar att det finns en romantisk bild av veterinärer som influerar unga människor. Egna erfarenheter av praktikanter vid stuterier, som har fått sin syn på professionens arbete reviderad, bekräftar Karins slutsats:

Det är inget sådant där gulljobb. Det är det absolut inte utan det är ett otroligt hårt jobb. Det är rätt bra att testa på som praktikant. Testa en eller två veckor så kan vi se om du vill gå vidare. Det finns de som inte klarar två dagar. Så det är väldigt påfrestande.

Under utbildningens gång och vid praktiker skiljs agnarna från vetet, menar veterinärerna. Lena instämmer i att det är ett tufft yrke och menar att hon är osäker på om hon skulle vilja att hennes barn blev veterinärer. Även hon menar att det finns en skev bild av vad en veterinär faktiskt gör eller hur det är att jobba som en veterinär. Karin använder uttrycket "gulljobb". Lena förklarar å sin sida att man ska vara medveten om att det inte bara är att klappa på djur. Arbetsbelastningen är snarare tuff. Som en eftertanke tillägger hon dock att det ju också är ett kul och spännande jobb.

Vid en konferens i England några veckor innan vår intervju mötte Beatrice några svenska studenter som hon kom i samtal med. Studenterna beskrivs som framför allt naiva av Beatrice.

Det är tydligen jättemånga där [på utbildningen] som är vegetarianer eller veganer och som har inställningen att de inte ska döda några djur. De hade nog aldrig varit i en svinbesättning. Hurdan veterinär ska du bli egentligen? Jag tycker att det är en viktig del att man hjälper folk att ta bort de här djuren som är kroniskt sjuka och mår dåligt och inte kan bli bra. Visst det är tråkigt men det är mer för att ägarna blir ledsna. Men inte för att man tar död på djuret. Det känns ju som en välgärning tycker jag. Jag undrar om dom med den inställningen kan ... 
- Inga djur ska dödas och jag ska hjälpa alla djur! (Beatrice föreställer sin röst, mjuk och ljus)

Ska man sen jobba med lantbrukets djur. Det handlar ju om livsmedelsproduktion. Jag menar alla djur ska ju ätas upp förr eller senare. Jag fattar inte att man söker sig till den utbildningen då. Men det är klart, de går ju där fem och ett halvt år, så en del kanske ser verkligheten i ögonen [under tiden för utbildningen].

En äldre, visare generation ställs i intervjupersonernas berättelser mot en ung, naiv generation. I ovanstående fall ställs att hjälpa gulliga djur mot påfrestande arbetsförhållanden med svinbesättningar och avlivningar. Farhågorna att den nya generationens blivande veterinärer inte vet vad de ger sig in i blandas med beskrivningar av vad som karaktäriserar veterinärens arbete.

I en vidare dialog om de nya studenters naivitet kommer jag och Beatrice in på de krav på arbetslivserfarenhet som tidigare tillämpats på bland annat veterinärutbildningen. Beatrice menar att det är ett kriterium som kunde använts bättre då erfarenhet från att jobba i labb räknades lika mycket som att ha suttit i kassan på ICA.

Jag tycker att det skulle värderas högre att ha arbetat med något som har med djur att göra. Man kan ju ha jobbat i en ladugård till exempel. Mjölkat kor eller något. Det är ju en erfarenhet som väldigt många saknar idag. De vet ju inte ens hur det går till. Jag menar de har bott i stan hela sitt liv och mjölken kommer i paket. Hur blir det då när man kommer ut i en kobesättning utan att veta någonting och känner sig jättedum? Några av mina kurskamrater kom ju direkt från gymnasiet och de kanske hade lite erfarenhet, men de var ju så unga då, så att när dom skulle jobba sin första sommar hade de ju lite problem med djurägarkontakt och så. Då tänkte nog djurägaren:

- Ska den där lilla stumpan ...!

De kanske i och för sig var jätteduktiga men hade inte det rätta sättet att prata med folk och ingav inte ett förtroende på samma sätt. Det var nog lite problem för en del av de där tjejerna. För de som kommer från gymnasiet de hade ju femma i allting, de hade ju inte gjort annat än att plugga.

Hon beskriver den nya generationen som först och främst oerfarna särskilt vad gäller livet på en bondgård. Några av hennes egna kurskamrater kom direkt från gymnasiet, ett säkert tecken på att de var duktiga på att plugga men också något som Beatrice menar påverkade kommunikationen med djurägare. En omständighet att hålla i 
minnet är att Beatrice var cirka 30 år då hon påbörjade veterinärutbildningen i mitten av 1980-talet.

Flera av intervjupersonerna kommer också in på aspekter av veterinärprofessionen och veterinärers beteenden som de inte tycker om. Det som ogillas lyfter fram deras egna egenskaper som innefattar ett mer korrekt beteende. I en anekdot från några år efter att hon avslutat veterinärutbildningen berättar Christina om karaktärsdrag som hon har haft fördelar av:

Men i alla fall så började jag jobba som distriktsveterinär och så frågade de på hästkliniken vid travbanan om jag inte kunde komma dit och jobba. För jag gick med och auskulterade där då jag hade väldigt lite utbildning på hästsidan under studietiden. De hade några veterinärer där som slängde hästarna i väggen och småflickorna grät. Så de visste ju inget om mig egentligen men de tyckte väl att jag kanske inte var riktigt lika burdus mot kunderna.

Christinas alternativa sätt att behandla såväl hästar som kunder premieras trots hennes då begränsade utbildning. Hur gamla de som benämns som småflickor faktiskt är och om det är de som senare refereras till som kunder är oklart. En kontrast illustreras dock där veterinärerna och småflickorna befinner sig på kollisionskurs. Även Anja berättar om det hon ser som problem i veterinärprofessionen:

Det är tyvärr ett problem bland veterinärer sen tidigare. Ganska många är ganska arroganta och förmer. I områden där det inte finns någon annan veterinär så kan man bete sig hur man vill. Men det finns många som åker hur långt som helst för att komma till en veterinär som dom trivs med.

Anja har nyligen öppnat upp en liten klinik på en mindre ort i Östergötland. Hon har under flera år varit verksam deltid som ambulerande veterinär samt har haft viss mottagning i hemmet. Ortsborna är därmed förtrogna med henne. Anja positionerar sig gentemot veterinärer som är arroganta eller överlägsna och ger därmed sig själv en roll som ödmjuk. Arrogans kan accepteras på områden där det inte finns några alternativ medan ödmjukhet kan få djurägare att färdas lång väg. Anjas strävan är att vara den sortens veterinär som lockar djurägare snarare än bara accepteras. I sitt uttalande dömer inte Anja ut professionen som sådan utan delar snarare upp den utifrån det hon bedömer som ett bra respektive ett dåligt beteende. Själv ser hon sig tillhöra delen med ett bra beteende.

Om vi ska summera den bild av veterinären och dennes arbete som hittills har trätt fram så blir det en fylld av kontraster. I en nostalgisk reflektion skildras veterinären som en respekterad auktoritet $\mathrm{i}$ en tid då nya veterinärer sattes på prov då de började jobba på distrikt. Dagens studenter utmålas komma direkt från gymnasiet med liten 
eller ingen erfarenhet av djur och saknar dessutom såväl arbets- och yrkeserfarenhet som en insikt i vad arbetet faktiskt innebär.

\section{Feminisering?}

Intervjupersonernas berättelser vittnar om en profession i förändring, där andelen kvinnor i jämförelse med män stadigt har ökat. Erfarenheterna från utbildningen har ett stort spann med 30 år mellan den tidigast och senast examinerade. Karin är den som är äldst av intervjupersonerna och är också den enda som tog sin examen på 1970talet:

Jag började på veterinärutbildningen 1971. Vi var 50 som kom in och jag tror att det var ungefär hälften tjejer. Däremot när man kom ut sen då ... Vi var klara att börja jobba 1976. Sommaren 1976 så fanns det ju fortfarande det här att vi inte riktigt var accepterade som kvinnor men däremot om man gjorde något bra så då var det godkänt direkt. De var lite tveksamma när vi kom in. Sen gick det jättebra.

Karin skiljer i ovanstående citat mellan tjejer som börjar utbildningen och kvinnor som är klara med utbildningen. Acceptansen av de nyutexaminerade kvinnorna var avhängig om de "gjorde något bra". Ett bra arbete vägde upp tveksamheten som kvinnorna möttes av. Denna tveksamhet benämns dock som tidsbunden, som om Karin inte tror att det är på samma sätt nu. Kvinnors inträde i veterinärprofessionen är ett ämne som väcker många tankar och funderingar hos intervjupersonerna. I några reflektioner ges olika förklaringar till skiftet, ibland konstateras endast fördelningen. Beatrice tog sin examen 1989:

När jag gick på utbildningen då var det var lite överskott på tjejer men vi var nog ganska fifty/fifty ungefär. Nu är det ju nästan bara tjejer. Men var är killarna då? Går de på IT-linjer eller? Men det är väl tjejer där också, det är ju tjejer överallt.

Beatrice funderar över de förändringar som skett sedan hon gick utbildningen. Som hon minns det var fördelningen relativt jämn då. Något hon ser som mer fördelaktigt än en majoritet av kvinnor. I likhet med Beatrice så funderar Anja (som tog examen 2000) över den sneda könsfördelningen vid olika utbildningar och vad den kan bero på:

Sen i slutet av 80-talet och början av 90-talet så blev det som det är. Teknik blev väldigt inne och det blev mycket jobb inom data. Det blev ju den här boomen inom IT. Många killar var väldigt attraherade av det. Det var 
snabba pengar, teknik och man kunde hålla på med sina hobbys. Medan tjejerna var mer ... de kände mer av ett kall kan man säga.

Både Beatrice och Anja lyfter fram IT och teknik som möjliga utbildningsområden dit killar numera söker sig. Anja menar att kvinnor snarare tycks basera sina utbildningsval på att de känner ett kall.

Karin minns tillbaka till tiden när hon själv började arbeta som veterinär och reflekterar över att var många äldre män i yrket då:

Det har ju varit många gamla uvar i länet sen man själv körde igång. Det var ju liksom bara gubbar. Det har ju, som sagt var, varit ett helt manligt dominerat yrke och nu är det ju helt tvärtom. Jag tror ju i och för sig inte att det är bra alltså. Det är mycket bättre med uppblandade arbetsplatser det är ju så faktiskt. Nu är det är ju de gamla uvarna som hänger kvar där.

Karin är osäker på om det är bra att yrket numera är dominerat av kvinnor. Uppblandat är bättre menar hon. Det är det gamla uvarna som hänger kvar som gör att arbetsplatserna inte enbart består av kvinnor. En intressant uppdelning mellan män och kvinnor görs genom att äldre manliga veterinärer liknas vid uvar. Ytterligare en djurmetafor används av Anja:

Under hela 90-talet så var det överskott på veterinärer och sen började de här gamla rävarna gå i pension. Många fler kvinnor kom in och de tog ut sina semestrar, tog kompledighet, föräldraledighet - de förde vanliga liv. Så då blev det mycket bättre arbetsmarknad under 2000-talet.

Anja menar att arbetsmarknaden för veterinärer har gynnats av ett ökat antal kvinnor. Inträdet av kvinnor som i jämförelse med de äldre männen tar ut semester och föräldraledighet, har gett fler öppningar och möjligheter på arbetsmarknaden.

I Östergötland fanns det under några år ett nätverk för kvinnor som är veterinärer och företagare. Vid tillfället för intervjuerna har det dock varit vilande under några år. Lena berättar att hon då hon startade sitt företag år 2009 blev inbjuden att delta i nätverket och reflekterar över dess varande:

Det är kanske ett sätt att krossa gubbväldet också (skratt). Alltså det är inget fel på vissa av gubbarna men det är ju ändå så att man behöver på något sätt hålla ihop. Det är lite tråkigt, för jag har lite problem med sådant där från första början med kvinnligt och manligt. Jag har försökt att hålla mig utanför den där ramen där man ska befinna sig. Jag har nog varit ovanligt killaktig men samtidigt så tycker jag att det är viktigt. För det finns ju ändå sådana problem och då måste man väl på något sätt göra 
någonting för att balansera det i alla fall. Så jag tycker att det är roligt att det finns ett nätverk.

Detta kan kontrasteras med ytterligare av tillbakablick från Karin som berättar om problemen hon stötte på i samband med att hon började doktorera i början av 1980talet:

Det fanns en man som hade byggt upp ett travstuteri i Stockholm, och han var på väg tillbaka till skolan [SLU]. Så det var egentligen därför som jag började där. Jag hade liksom bespetsat mig på att få lära mig utav honom. Men han ville inte ha någon kvinnlig medhjälpare. Utan det var en kille som fick hjälpa honom. Så han var inget att ha. Men så var det mycket på den tiden faktiskt, det var det. Så jag fick ta mig fram själv och skaffa mina kontakter och så småningom så lyckades vi få forskningspengar. (...) Men sen när jag hade varit där ett antal år. Den här personen som inte hade accepterat mig, han skulle åka och jaga älg och då fick jag ta hand om hans stuteri. Så småningom accepterade han mig mer och mer. Men han var absolut ingen hjälp i avhandlingen. Det var en liten besvikelse.

Som ett svar på att bli bortvisad väljer Karin att själv avfärda mannen ifråga som "inget att ha". Att bli bortvisad på grund av sitt kön ser hon samtidigt inte som ovanligt på den tiden. Det var först efter ett antal år som Karin erhöll någon slags acceptans från mannen. Hon beskriver det som en besvikelse men också som en motgång som hon överkom. Karin menar dock att saker och ting har förändrats sedan dess:

Men på veterinärsidan känns det inte alls som då; att vi var lite motarbetade. Det känner jag inte alls. Det finns många kvinnor som kommer fram så det kommer att ändra sig. Den akademiska världen är också väldigt mansdominerad. För mig är ju jämlikhet något självklart.

Ökningen av kvinnor beskrivs som en anledning till denna förändring bibehålls - det vill säga att kvinnor inte motarbetas på samma sätt som tidigare. Karin poängterar att jämlikhet för henne är något självklart men indikerar därmed också att det kanske inte är det för alla andra.

Erfarenheterna av just bemötanden i relation till kön är olika bland intervjupersonerna. Annika beskriver det som att hon har fått ett bra bemötande:

För mig, även då när jag var ute på distriktet så var det aldrig några konstigheter. Fast man var kvinna och de inte var vana vid det. Tvärtom så tycker jag att man har fått väldigt bra bemötande från djurägare. Det har aldrig varit några konstigheter. 
Distriktet beskrivs som en speciell omständighet i sammanhanget. Bemötandet bedöms utifrån de försvårande omständigheterna av att vara kvinna, något som kunderna inte var vana vid. Allt detta till trots så var alltså bemötandet bra. Eva berättar om sina upplevelser på konferenser:

Det var rätt roligt för förut när man åkte på de här hästkonferenserna ... där träffades ju alla klinikveterinärer då en gång om året på två dagars möte och då var det nog ofta så att männen de diskuterade hur stora instrument de hade till sin kirurgi medan tjejerna alltid pratade om:

- Ja jag vet inte om jag vågar mig på den där operationen och det känns lite osäkert och den där bedövningen tycker jag är svår att få och ta!

Det var mera att man diskuterade sina svagheter medan männen bara diskuterade hur duktiga de var på olika saker. (...) Men det finns ju oerhört skickliga företagsledare, tjejer som jobbar som veterinärer [ger exempel på en som blivit utnämnd till årets företagare]. Fantastiskt bra resultat och jätteduktig veterinär och väldigt omtyckt av sin personal. Så att det finns ju kvinnor som kan göra det precis lika bra. Men hon förde också samma diskussion.

Alltså mycket mildare framtoning. Men jag tror att det är en mycket större acceptans i samhället idag också.

Exemplen på en "mild framtoning" som ges präglas av osäkerhet och självkritik. Eva beskriver ett sammanhang där män framhäver sina styrkor och kvinnor framhäver sina svagheter och reflekterar över att det förmodligen inte är något som är unikt för veterinärprofessionen. Ett exempel på undantag erbjuds, en skicklig företagsledare som är kvinna och som har haft stora framgångar, trots en mild framtoning.

Under åren 2006 och 2007 använde sig SLU av så kallad viktad lottning vid antagningen till veterinärutbildningen. I efterhand stämdes SLU för olaglig könsdiskriminering vid antagningen av 44 kvinnor. SLU fälldes sedermera för att ha diskriminerat kvinnliga sökande till veterinärutbildningen. Susanna och Karin kommenterar båda kvoteringen vid intervjutillfällena. De har dock lite olika ståndpunkter. Susanna återkommer till problemen med en enkönad arbetsstyrka:

På distriktet hade vi ju en manlig stationschef när jag började men han gick i pension efter några år, så sen var det bara tjejer. Det märktes. Det är lite tråkigt och jag vet inte om det kommer att svänga åt andra hållet. Det var ju synd att kvoteringen inte kunde få vara. Det tyckte jag var jättebra. De fick ju betala skadestånd till jag vet inte hur många det var. 
Vad det var som märktes förklarar inte Susanna. Vi vet dock sedan tidigare att hon har talat om stora grupper med kvinnor som besvärliga. En äldre manlig chef ges som kontrast till det som sedan märktes. Kvoteringen, som beskrivs ovan, togs bort och i den vägen tycks i alla fall inte någon ytterligare förändring initieras. Karin ger sin syn på professionens numerära feminisering och kvotering:

Jag är mer för erfarenhet. Låt bästa kvinna vinna. För det var ju tal om en annan kvotering då för väldigt länge sen och det blev ju aldrig något. Nej jag tror inte att man ska ha kvotering. Däremot så tror jag nog att det vore bra med intervjuer, för det hade de ett antal år. Men jag vet inte för yrket som sådant. Visst är det bra med en blandning - men jag tror inte på kvotering - det gör jag inte. (...) Jag vet inte vad man ska säga om fördelningen och framtiden. Det sägs att lönerna kryper ned när vi är mycket kvinnor som inte slåss för lön. Sen är det ju så att distriktsveterinärer och annat ... ibland är det bra att ha någon som är stark och det är det även i mitt gebit när man håller på med hingstar. Man behöver inte vara veterinär för det $\mathrm{i}$ och för sig.

En förändring vad gäller könsfördelning har skett inom veterinärprofessionen och intervjupersonerna är överens om att det har påverkat professionen. Det råder dock skilda meningar om hur och framför allt om förändringarna är positiva eller negativa. I det ovanstående kopplas män samman med arbetsområden som IT och teknik. De beskrivs som drivna av en strävan efter pengar och varandes plikttrogna, bättre på att förhandla lön, att vara fysiskt starka och bra på att framhäva sina styrkor och inte lika besvärliga i grupp. Kvinnor blir i jämförelse beskrivna som uppoffrande, besvärliga och med en mild framtoning. Kvinnor är dessutom lediga mer. Det råder delade meningar om kvotering men att blandade grupper med både män och kvinnor är bra är en utbredd åsikt bland intervjupersonerna.

\section{Från kossor till katter?}

Att yrket har förändrats vad gäller vilka djur som utgör majoriteten av veterinärens arbete är inte något konstigt i sig. Förändringar i djurhållningen och samhället i stort har påverkat även veterinärens vardag. Det finns färre lantbruksdjur att behandla samtidigt som sällskapsdjuren ökat i både antal och värde, såväl ekonomiskt som känslomässigt. Sandra kommenterar försöket med kvotering, som nämnts i ett tidigare avsnitt, med att det hade varit bättre att kvotera utifrån val av yrkesinriktning snarare än kön. Hon menar att de bakomliggande orsakerna till kvoteringen var rädsla:

Det som händer när det är mycket tjejer det är ju att de får barn (det är ju livets gång) och att de inte vill jobba jour. Men det finns ju en massa killar 
som inte vill jobba jour heller. Det jag tror att de är rädda för, det är att alla flickor ska jobba med smådjur och så ska det vara smådjurskliniker eller vara anställda och så finns det inga som kommer ut och drar ut kalvar på nätterna. Men det finns ju faktiskt tjejer som är intresserade av det. Jag hade inte tänkt hålla på med smådjur. Jag ville vara distriktsveterinär men när jag var näst intill färdig då blev jag faktiskt värvad till djursjukhuset i Linköping.

Sandra reflekterar över att ovilja att arbeta jour inte behöver vara kopplat till kön och positionerar sig själv som en av de tjejer som faktiskt ville bli distriktsveterinär men där arbetsmöjligheter istället ledde in henne mot smådjur. Susanna tror att kön har betydelse i valet av yrkesinriktning, i valet mellan stora djur och smådjur:

Det blir ju också förändrat tror jag när det i princip bara är kvinnor, kanske till och med unga tjejer. Eftersom man fokuserar så mycket på betyg idag så är det många som kommer in som kanske kommer direkt från gymnasiet tror jag. Det är väl allt vanligare. Då kanske man som tjej inte väljer ko-praktik i första hand. Utan att man har den här bilden av smådjursveterinär kanske. Det tycker jag att det finns en tendens till. Jag hörde att de på distrikt har svårt att få vikarier nu för tiden. Jag vet när jag gick ut, det var ju inte så hemskt länge sen, då var det ju riktig huggsexa kring de här vikariaten på distrikt. Alla ville jobba på distrikt.

Bilden som målas upp är att kvinnor som kommer direkt från gymnasiet väljer smådjur som yrkesinriktning snarare än lantbruksdjur. Ett samband mellan ett ökat antal kvinnor i utbildning och ett minskat intresse för att vikariera på distrikt antyds här. Susanna relaterar förändringen till tiden för sin examen år 1995 och en klass med förhållandevis många killar (14 i en klass på totalt 60-65 personer).

Flera av intervjupersonerna menar att de först och främst, då det begav sig, utbildades till distriktsveterinärer. Det fanns givetvis även då smådjur och hästar men målet med utbildningen upplevdes vara att den examinerade skulle klara av att "kvarta", det vill säga jobba på distrikt.

Yrket har blivit lite snuttifierat. När vi utbildade oss så var det till distriktsveterinärer. När man gick ut var man fullfjädrad distriktsveterinär. Ko-medicin och förlossningar det kunde man utan och innan.

Här görs en jämförelse med hur det var förr, i detta fall vid utbildningen. Rebecca tog examen år 1983 och menar att studenterna hade med sig mer kunskaper då än nu. Även Annika ger oss en återblick till gamla tider, i detta fall rörande distriktsveterinärens vardag: 
Förr var det så att man hade sin fru som tog telefonen och sen var man ute och jobbade på vägarna som distriktare då. Det var ju inte så mycket smådjurspraktiker då.

I ovanstående citat illustreras hur distriktsveterinärens arbetssituation har förändrats. Det var en tid innan mobiltelefoner och med hemmet som bas. Distriktsveterinären var en gift man som inte jobbade med smådjur. Denna koppling mellan mannen, i egenskap av distriktsveterinär, och det som ofta betecknas som stora djur gör flera av intervjupersonerna.

Annika beskriver sin verksamhetsinriktning som smådjur. Det vill säga det som inbegriper hund, katt och andra mindre djur:

Från början var det ju lite så där att - Vad då starta upp en smådjursklinik långt ute på landet? Då var det ju till exempel många som trodde att jag bara körde på lantbrukets djur, för att det var på landet. Samtidigt är det inte många som är medvetna om att jag bor väldigt centralt egentligen. För ofta så måste man ändå ha bil.

Associationen mellan en verksamhet belägen på landsbygden och lantbruksdjur gjordes i detta fall. Beatrice klinik ligger mitt inne i stadskärna i en medelstor östgötsk stad. En liknande association som ovan skulle i detta fall betyda att hon arbetar med smådjur. Med sådana generella antagande missar vi dock ofta målet visar det sig:

Jag har några boskapsbesättningar. Men det är inte så mycket. Det har blivit mindre, för att det har varit en sådan där strukturomvandling. Besättningarna har ju blivit större och större så i det här området finns väl tre riktigt stora mjölkbesättningar och de har inte jag någon utav dem. (...) Häst är ju det stora som jag har nu. På kliniken så är det nog ekonomiskt fifty/fifty häst och smådjur. Men då är det ju både [anställd] och jag som jobbar med smådjur. För mig är det väl mer häst än smådjur.

Beatrice arbetar med lantbruksdjur, hästar och smådjur i sin verksamhet. Att det inte är så mycket arbete med lantbruksdjur längre förklarar hon med den strukturomvandling som skett. Hästar är det djurslag som Beatrice ser som sin huvudinriktning. Ekonomiskt sett står hästar och smådjur för ungefär lika stora delar i verksamheten. Även Anja arbetar med samtliga tre grupper djur i sin verksamhet. Hon förutspår dock ett större behov av hennes tjänster för hästar snarare än för mjölkkor:

Det finns inte så många mjölkgårdar kvar här, det är bara tio stycken eller så. Så det beror lite granna på vad dom vill. Om de är intresserade av att ha mig som veterinär då ser jag till att jag har grejer hemma. Men om de 
inte är intresserade så kan jag inte hålla massvis med grejer hemma. Jag kan hålla lite akutgrejer hemma. Men häst tror jag att de kommer vara väldigt intresserade av.

Av de stora djuren tycks hästar vara vanligast förekommande i det praktiska arbetet för flera av de intervjuade veterinärerna. Men även när det gäller hästar finns det föreställningar om manligt och kvinnligt.

Om man är på en hästkurs i England då är det ju fifty/fifty ungefär och det är likadant i USA på hästkurser. Börjar man titta på smådjurskurser då är det mer tjejer. Det ser man ju också i USA att dom yngre veterinärerna ... där är det nog överskott på tjejer om man ser på de som är yngre. Om man åker på en konferens då är det ju även äldre veterinärer. Då är det ju verkligen ett överskott på män som jobbar med hästar.

Det Beatrice avser med fifty/fifty är könsfördelningen på hästkurser i England och USA. När det gäller smådjurskurser är det dock fler tjejer. Som jag redan varit inne på syns professionens numerära feminisering tydligt mellan olika generationer. Bland de yngre veterinärerna är det fler tjejer och bland de äldre är det fler män. Vid konferenser snarare än kurser ökar antalet äldre veterinärer som deltar och då märks en tydlig överrepresentation av män som jobbar med häst.

Jag ville ju jobba med stordjur, i alla fall inte med smådjur. Utan jag ville jobba med stordjur och helst med hästar då - det hade jag ju hållit på med. Men det insåg man ju att det blev ju ganska prestigefyllt. Det är ju dollartecken stämplade på dem på sätt och vis. Hästeriet är ju dyrt.

Christina styrker föreställningen att stora djur är mer attraktiva att arbeta med än smådjur men även att hästen är den representant för stora djur som är mest prestigefylld att arbeta med. Hon går så lång som att beskriva dem som stämplade med dollartecken. Hästen är ett värdefullt djur, för såväl djurägare som veterinär. Eva hade från början inte avsikten att bli hästveterinär:

För det kändes som att de var ju lite gudar så där. Det var ju jättefina, skickliga, otroligt smarta manliga veterinärer allihop förstås. Utan jag hade väl tänkt att jag skulle bli distriktsveterinär kanske eller något sådant. Så att styrs man ju dit man ska på något sätt och hamnar i sin fålla. Men så gick det till.

Sandra beskriver med ett sarkastiskt tonfall den klassiska veterinären såsom en hästveterinär:

Den klassiska veterinären som tjänar bra är det en man över 50 som håller på med hästar, som är ganska tystlåten, lite hemlig och som inte säger vad 
han gör. Han kan gärna vara otrevlig, för det gör ingenting, för att de (kunderna) tror att han är duktig då. Ju mer svårpratade man är vet du. Så har det alltid varit. För att det är bara de här hästveterinärmännen över femtio, som kan vara oförskämda mot folk.

Hästen beskrivs i det ovanstående som ett djur som företrädesvis är för manliga veterinärer över femtio. Här möter vi även en karaktärisering av den typiska veterinären. Hästveterinären beskrivs som en gud Eva - någon som står över andra ifråga om skicklighet och intellekt. Han beskrivs också som en man som kan vara såväl otrevlig och svårpratad. Ett beteende som även sanktioneras av kunderna.

Utifrån beskrivningen tycks det som att hästen alltid har varit högt värderad och ett djur som ger prestige åt den som hanterar den. Karin berättar dock en något annorlunda historia. Denna gång dock förlagd till akademien:

Så jag var i Västergötland först och sen så sökte jag mig till lantbruksuniversitetet då och var ju intresserad av häst men det fanns egentligen inget hästintresse på universitetet. Det var inte accepterat. Det var produktionsdjuren som man skulle jobba med. Så att jag kom med på ett forskningsprojekt om galtsperma. Det jobbad jag med 1977-82. Jag lyckades aldrig bli riktigt intresserad av gris. Men jag var ju intresserad av häst från början.

Vid detta tillfälle, under 1970-talet hade hästen ingen särskild särställning, i alla fall inte vid SLU menar Karin. Produktionsdjuren var snarare det som prioriterades på den tiden. Karin hade ett intresse av häst och hade dessutom observerat ett forskningsproblem som hon ville gå vidare med. Det gjorde hon också slutligen. Numera är hästen en del av många veterinärers vardag och det gäller både kvinnor och män oavsett vilka föreställningar som är rådande. Anja, som tog sin examen år 2000, arbetade under sina första år som stordjursveterinär på Irland. För Anja är de stora djuren den bästa delen med att vara veterinär. Hon förklarar att arbetet med lantbruksdjur ger en frihetskänsla och att pengarna i samband med joursamtal för häst dessutom är väldigt bra. Christina driver det företag som har högst omsättning bland intervjupersonerna, en hästklinik. Hon berättar om kraven som ställs på en hästklinik:

Det är väldigt speciellt med en hästklinik för hästar de är stora, de är snabba och de är jättefarliga. Det kräver stora utrymmen och det går inte att springa igenom lika många hästar på en dag som man springer igenom hundar eller katter. Det går inte att jämföra liksom. Du måste ha ett helt annat säkerhetstänkande och det kräver mycket större ytor.

I kontrast till de stora pengar som finns att tjäna på att behandla hästar så ställs en rad krav på utformningen av verksamheten. Christina lyfter fram utrymmet som en viktig 
faktor men även säkerheten och det antalet patienter som veterinären kan hinna med att behandla på en dag. Detta i jämförelse med hund eller katt.

Beatrice menar att det är fler och fler veterinärer som inriktar sig mot sällskapsdjur mycket på grund av att det är en expanderande djurgrupp. Katten är ett djur som beskrivs ta allt mer plats när det gäller vilka djur som veterinärer främst behandlar:

Förut var ju katt ett sådant här djur som man bara hade. Men nu är ju katten också familjemedlem. De är ju ofta lika omhändertagna som hundarna. I de flesta familjer i alla fall. Så det har ju ökat väldigt mycket. Det ser vi ju när vi ser statistiken från varje år, att hundarna ligger ungefär på samma nivå. Vi har ju kommit upp i en stabil nivå. De som bor runt omkring oss som vill åker till oss. Medan katterna blir fler och fler för varje år. Katter och kaniner ökar. Det är likadant med kaniner. Många djur är liksom mera nära nu. Det är barnens första riktiga egna djur. Så de åker man ju också till veterinären med mer än vad man gjorde förr. Då var det mer - Ja den är sjuk - den dör väl!

Kattens status har ökat och betraktas numera ofta precis som hunden som en familjemedlem. Denna förändring märker även Beatrice på sin klinik där behandlingar på hundar håller sig stabilt medan det ökar för katter. Som en familjemedlem har synen på kattens mående förändrats. Det som förr hade ryckts på axlarna åt innebär nu en tur till veterinären. Rebecca reflekterar över synen på katten och skillnaden mellan stad och landsbygd. Men även hur veterinären kan influera detta:

Det fanns ju en gammal distriktare i här i trakten som dog för länge sen men det märktes att folk här har levt $\mathrm{i}$ tron att veterinärer vill inte behandla katter. I början så tyckte jag nästan att det var skrattretande när de kunde ringa och frågade om jag tog emot katter.

- Ja - självklart!

Det är klart att man får komma och lämna katter. Nu har jag väl kommit upp till att jag har 35 procent katter och 65 procent hundar här. Men det är fortfarande långt ifrån hur det var [vid den tidigare kliniken]. Det tycker jag är helfestligt. Det är liksom 3,7 mil emellan och ändå är det som två olika världar. Var är katterna?

Rebecca bytte pendling till en stad mot egen klinik på landet och fick då uppleva hur synen på katter kan skilja sig. Rebecca skrattar gott åt tanken att folk ringde för att fråga om hon tog emot katter. Förändringen av kattens status var hon bekant med från sin tidigare verksamhet men hon var inte beredd på att det fortfarande skulle finnas 
sådana attityder. Annika för fram fördelarna med att behandla katter och ger oss den andra sidan av myntet:

Jag är lite specialintresserad av hudproblem och så är jag väldigt intresserad av katter. Katter är ju mer detektivarbete när det gäller sjukdomar och så, för de går ju iväg för att överleva. Hundarna är mer tydliga. Så min inriktning det är ju hund och katt. (...) Katt kan man göra det mesta med och även ensam då. Det är litet och behändigt.

En farhåga bland intervjupersonerna, men även vid SLU, är att dagens kvinnliga veterinärstudenter bara vill befatta sig med gulliga sällskapsdjur. Samtidigt framhåller flertalet av intervjupersonerna att de, sitt kön till trots, faktiskt ville arbeta med stora djur och på distrikt en gång i tiden. Men inte minst en förändring i djurhållningen vad gäller kobesättningar har förändrat saker och ting. Veterinärens arbete, visar det sig, koncentrerar sig till hästar och sällskapsdjur.

\section{Vem gör vad?}

Vad veterinärer gör och inte gör samt vilken status de olika aktiviteterna har råder det delade meningar om. Kirurgi har en särställning inom humansjukvården och så även inom djursjukvården. Erfarenheterna av kirurgi har varierat bland intervjupersonerna. Annikas första erfarenhet av kirurgi när hon kom som nybliven veterinär till en klinik blev dramatisk:

Då blev det så där att även jag skulle gå jourer och så där - fast jag inte hade så stor erfarenhet liksom. Men man hade ju bra arbetskamrater som ju är det viktiga. Annars så chefen - lämnade en med skalpellen i handen i princip.

Stödet fann Annika främst i sina arbetskamrater. Sandra hade, åtminstone till en början, en liknande upplevelse i sin introduktion till kirurgi på ett djursjukhus:

Jag började där våren 1989, när jag varit där i två dagar så fick jag min första stora operation. Jag var nygift och fick barn i december 1990 och när jag hade varit på mammaledighet och då nästan jobbat två år och kunde göra det mesta så började eländet. När jag kom tillbaka fick jag inte göra någonting. Sen var det inte kul att jobba där. Innan så var man påläggskalv och det var kul och man fick liksom prova på. Sen så kom man tillbaka som mamma och då var man plötsligt ... oren? ... och fick inte gå in på operationsavdelningen. Då skulle jag mest hålla mig undan. Då hade ju de här killarna kommit och pinkat in sina revir. Så då var man mest i vägen. Nej, jag kunde nog ingenting. Så då fick jag inte operera plötsligt, 
men på jourerna skulle jag operera - fast egentligen var jag tvungen att ringa någon bakjour då för jag kunde nog egentligen inte i alla fall. Han som har djursjukhuset var väl den som var värst skulle jag vilja påstå. Jag vet inte varför men det var inget roligt $i$ alla fall. Jag var kvar ett tag till, så det blev väl totalt nästan fyra år. Den sista tiden där var inte så rolig. Sen så gick jag ju över till att bli lärare.

Känslan av att vara i vägen och att betecknas som okunnig var jobbig för Sandra och det hela slutade med att hon efter nästan fyra år sökte sig bort från djursjukhuset och tog en lärartjänst istället. Sandra beskriver det som att förändringen kom i samband med hennes mammaledighet. Innan dess fick hon operera men efteråt var allt förändrat. Som enda kvinnliga veterinär vid ett djursjukhus upplevde även Rebecca en särbehandling när det kom till kirurgi:

Sen hamnade jag på djursjukhuset, de hade fyra lediga tjänster just när jag började. Jag jobbade där i två och ett halvt år men där var en riktigt gammaldags chef som inte pushade på kvinnor direkt. Jag var den enda kvinnliga veterinären där och fast jag själv tyckte att jag hade talang för kirurgi, så blev killar som kanske inte hade fullt så mycket talang mer coachade. Jag tänkte att det här funkar inte, jag måste hitta på något annat.

Det hela slutade med att Rebecca sökte sig bort från djursjukhuset och startade upp sitt första företag tillsammans med en kollega. Rebecca funderar i vårt samtal vidare kring manligt och kvinnligt i förhållande till kirurgi:

Det är lite som med kvinnliga piloter och så ... Det här klassiskt kvinnliga. Samtidigt skulle man vilja ha en manlig barnmorska? På något vis inbillar jag mig att där är kvinnorna bättre ... Men det här med kirurgi, det ska vara manligt? Något som jag tycker är otroligt tråkigt är medicinska utredningar och utreda diarréer. Usch det är tråkigt. Det ska vara kvinnogöra det där, man ska tycka att det är roligt att jobba med hudar och så där. Lösa kliande hundar som aldrig blir bra.

Rebecca kommer in på det som hon ser som klassiskt kvinnliga yrken. Samtidigt är det med stor skepsis i rösten som hon frågar sig om kirurgi kan ses som manligt. Som kontrast till kirurgi ger Rebecca det som hon betecknar som det tråkiga arbetet, medicinska utredningar. Sarkastiskt ifrågasätter hon att det är detta kvinnliga veterinärer ska tycka är roligt att arbeta med, snarare än med kirurgi. Med hjälp av sarkasm illustrerar Rebecca stereotypa föreställningar samtidigt som hon tar avstånd från och till viss del förlöjligar dem.

Lena har som ambulerande veterinär inte möjlighet att praktisera kirurgi såsom hon gjorde när hon var anställd vid en klinik. Istället får Lena nu till viss del ägna sig åt det 
som Rebecca finner synnerligen tråkigt. För Lena handlar det dock snarare om att vara flexibel och inställd på att det mesta kan dyka upp:

Jag har en väska med utrustning eller rättare sagt flera väskor beroende på vad jag ska göra för någonting. Man utrustar dom lite beroende på vad som ska ske och med lite extra för ibland dyker det upp en hund till som ska vaccineras bara som av en slump (skratt). (...) Man får liksom utgå ifrån att det kan hända fler saker.

Som anställd vid en klinik var kirurgi ett moment som Lena uppskattade. Det är dock en talang som det inte finns utrymme för att praktisera i en ambulerande verksamhet. Hon skrattar åt det faktum att det vid en inbokad, till synes enkel vaccinering, kan krävas större beredskap i form av utrustning. Det krävs flexibilitet för att kunna hantera överraskningar.

Bakgrunden till Rebeccas fråga ovan om huruvida kirurgi är något manligt står att finna i en upplevelse då hon deltog i en neurologikurs i Uppsala:

Vi skulle åka bil någonstans. Det var min bil, jag hade en sådan där sportbil, en 16 ventilers Golf GTI. Det var jag och en finsk manlig kollega som jag inte alls kände, en svensk manlig kollega och sen en finsk kvinnlig kollega. Sen började den här finska manliga veterinären, han var lite äldre, att för det första kommentera att det var färddator i bilen. Det var så oerhört. Sen började han undra vad en tjej gjorde med en sportbil över huvud taget. Sen började vi prata om jobb och kirurgi och då sa han att kvinnor ska hålla på med medicinska utredningar och inte med kirurgi. Då svarade jag att jag tycker att det är en enorm fördel att vara kvinna, att ha små händer och dessutom vara gammal pianist. Jag kunde inte riktigt bli ilsken på honom för jag kände honom inte. Men sen tänkte jag så här säg att vi skulle träffas i en årskurs och sen skulle någon av killarna ställa sig upp och säga att killar är bättre kirurger än tjejer. Alltså till och med killarna skulle tycka att han var helt puckad. De [män] har vassare armbågar så de kan ta sig in i operationssalar. Men han tyckte verkligen så att kvinnor bara ska hålla på med medicinska utredningar.

Bilen blir i ovanstående utgångspunkten i ett samtal som cirklar kring manlighet. Rebecca bryter mot en stereotyp könsmärkning då hon som kvinna äger det som kan betecknas som en sportig bil, något som den hon mötte såg som manligt. Mannen beskriver kirurgi som manligt och medicinska utredningar som kvinnligt. I en diskussion framför Rebecca det egna könets fördelar med små händer när det gäller kirurgi. I och med benämningen av den manlige finske veterinären som äldre framhävs generationsskillnader som en bakgrund/förklaring till diskussionen. Detta förstärks av att Rebecca ger ett exempel från den yngre generationen som utbildar sig 
till veterinärer. Rebecca menar att det handlar om att män har vassare armbågar än tjejer. Något hon menar krävs för att man [sic!] ska kunna ta sig in i operationssalen.

Eva och Christina har båda verksamheter med inriktning mot häst. Eva har genom åren pendlat mellan att vara egen företagare och anställd. Valet att gå över till att bli anställd igen under en period på 1990-talet baserades på en vilja att lära mer och nytt:

Det hade ingenting med firma eller anställda att göra utan det hade att göra med att jag ville göra andra arbetsuppgifter och lära mig lite mera. Jobba lite mer med kirurgi. Då måste man kunna söva och det kan man inte göra ensam ute i fältet utan det måste man göra på en klinik.

Eva lämnade under en tioårsperiod rollen som företagare och tog anställning på en hästklinik istället. Särskilt lockade kirurgin. I sin nuvarande verksamhet har Eva inte längre möjlighet att praktisera kirurgi:

Det är ju sporthästpraktik kan man ju säga. Stationärvård där jag skriver in patienter gör jag ju inte heller eftersom jag är ensam [veterinär]. Jag skulle ju få jobba dygnet runt om jag hade dem kvar. Utan det är som poliklinikverksamhet med inriktning sporthäst kan man säga. Jag tycker att det är roligt att hålla på med kirurgin men jag skulle aldrig hinna det som det är nu. Den här dagliga verksamheten tar så mycket tid. Jag gjorde det i många år och tyckte att det var kul. Men det här funkar jättebra också. För jag är ju road av det. Jag tycker fortfarande att det är spännande att börja på en hältutredning och hitta hur man kan lösa det. Så jag har inga bekymmer med det.

Kirurgin ser hon fortfarande som rolig men inte som ett måste för att vara nöjd med sitt arbete. Eva känner att hon i sin nuvarande verksamhet har en tillräcklig arbetsbelastning men även ett stimulerande arbete med hältutredningar. Den nuvarande verksamheten är poliklinisk ${ }^{44}$ med inriktning mot sporthäst och begränsar till viss del vad Eva kan göra rent praktiskt. Men intresset för kirurgi finns fortfarande kvar. Christina, med den lite större hästkliniken har en liknande situation:

Nu när vi är flera veterinärer så skulle man kunna bygga ut med kirurgi men samtidigt så finns det ju en massa kliniker där man håller på med kirurgi och det är ju ett rent hantverk och så måste man ha eftervård. 95 procent av de vi har här dom reder vi ju ut utan kirurgi. Då tycker jag kanske att man remitterar dem, den lilla procent ... men ändå är det ju där de stora pengarna finns. Fast för mig ligger ju utmaningen i att hitta stället som ska opereras och inte att stå och göra samma sak varje dag. Det är inte

\footnotetext{
${ }^{44}$ Poliklinisk verksamhet är i princip synonymt med öppen, primär djursjukvård. Att jämföra med stationärvård vilket betecknar vård av inneliggande patienter. SOU 2007:24, s. 68 .
} 
spännande nog för mig. Får man bara operera framknän och kotleder och hasleder hela dagarna då skulle jag tröttna faktiskt.

Christina framhåller risken för monotoni i arbetet som en faktor som talar mot en kirurgisatsning. Hon håller hellre fast i spänningen. Eva och Christina konstruerar ovan kirurgi som något som är roligt och inbringar pengar men som också kan bli monotont i längden. Hältutredningar kan vara minst lika stimulerande och spännande menar de båda.

Lena reflekterar över vilka behandlingar och ingrepp hon har möjlighet att utföra inom ramen för sin nuvarande arbetssituation:

Jag utför faktiskt nästan det mesta som går att göra på hundar och katter som inte kräver en operationssal eller liknande. Det vet jag att vissa veterinärer gör hemma, alltså opererar djur i magen på ett köksbord, och det ligger jättelångt ifrån min moral och vad jag kan tänka mig att göra. (...) Det finns ju veterinärer som agerar på helt andra sätt som kastrerar katter ute i ladugårdar. Men jag är inte född på det sättet kan man säga och jag vill inte sänka på den standarden. Jag vill ju ändå kalla mig för hund- och kattveterinär, smådjursveterinär. Då vill jag hålla den kvaliteten på det hela. Det är ändå en ökad risk för komplikationer. Det är inte etiskt försvarbart tycker jag.

Liksom Eva och Christina är Lena begränsad i vilka behandlingar och ingrepp som hon kan utföra samtidigt som hon också tidigare har uttryckt ett stort intresse för och nöje i att praktisera kirurgi. I det ovanstående utvecklar Lena diskussionen kring vad som är etiskt försvarbart för en veterinär. Att inte praktisera kirurgi på ett olämpligt sätt framhäver Lena som något statushöjande i sig. För henne handlar det om att hålla på en viss kvalitet och standard, även i förhållande till katter, vilka vi tidigare har sett ibland har en lägre status bland sällskapsdjuren. Föreställningar om vem som gör vad tar sig olika uttryck. Anja minns när hon var ute på ett jobb i trakten:

En kommentar som jag hört indirekt var när jag tog bort en häst för en lokal bonden. Då var det någon som sa:

- Och hon gör det också!

Det är det som är bra med distriktsveterinärjobbet. Man får ganska brett. Man blir inte så duktig på allt men man har i alla fall gjort det några gånger.

Den lokala bonden uttryckte förvåning över att Anja även kunde avliva hästar. Kommentaren var riktad till någon annan och oavsett om häpnaden involverade Anjas 
kön eller ej var det med en beundran i botten. Anjas egen tolkning var att det handlade om att hon var kvinna och besatt denna färdighet.

Vad som utgör veterinärens arbete och vilka aktiviteter detta innefattar finns det olika tankar kring. Att utföra arbetsuppgifter som ses som simpla kan ge värdefullt utrymmet att tänka och lägga upp en behandlingsplan. Den aktivitet som lyfts fram framför andra är kirurgi. Det beskrivs som något alla gör eller har gjort och tycker om. Statusen går inte att ta miste på. I det eftersträvansvärda blir kirurgi exklusivt och en arbetsuppgift som inte är för alla utan främst för män.

\section{Sammanfattning}

Bilden av veterinärprofessionen och veterinären som målas upp av intervjupersonerna är fylld av kontraster. En generell oro för vart professionen är på väg ställs mot nostalgiska återblickar. Samtidigt som de berättar om egna erfarenheter av att behandlas annorlunda som kvinnor i en tidigare mansdominerad profession så framhäver de ofta mäns egenskaper framför kvinnors. Både djurslag och arbetsuppgifter delas in i manligt och kvinnligt. Hästar och kirurgi har en upphöjd ställning och kopplas på ett eller annat sätt till män medan katter och medicinska utredningar kopplas närmare samman med kvinnor. 
Kapitel 8: Livet som veterinär och kvinna 
Del 3 


\section{Kapitel 9}

\section{Diskussion}

$\mathrm{H}$

är ställs redogörelsen för veterinärernas berättelser mot teori och tidigare forskning om småföretagande, profession och genus. Inledningsvis diskuteras företagande som en lösning och därefter analyseras samspelet mellan företagande och profession med hjälp av livsformsteori. Avslutningsvis diskuteras hur genus görs i företagande respektive profession utifrån olika nivåer och dimensioner.

\section{Företagande som lösning och livsform}

Intervjupersonernas berättelser visar på en mångfald när det kommer till tidigare erfarenheter. Synen på företagande och vem som är företagare, incitament för att starta och sätt att se på framtiden skiljer sig åt veterinärerna emellan. Inte heller i denna studie är kvinnor som företagare en homogen grupp (jmf Sundin \& Holmquist, 1989). Mönster framträder dock även i heterogena grupper. Majoriteten av intervjupersoner var veterinärer innan de blev företagare. Berättelserna från deras liv visar därmed en tidsmässig uppdelning mellan valet att bli veterinär och valet att bli företagare. Rebecca beskriver hur hon efter utbildningen började arbeta på ett djursjukhus men hur särbehandling som hon relaterade till sitt kön gjorde att hon valde att starta företag tillsammans med en kollega:

Jag jobbade där i två och ett halvt år men där var en riktigt gammaldags chef som inte pushade på kvinnor direkt. Jag var den enda kvinnliga veterinären där och fast jag själv tyckte att jag hade talang för kirurgi så blev killar som kanske inte hade fullt så mycket talang mer coachade. Jag tänkte att det här funkar inte, jag måste hitta på något annat. 
Sandras erfarenheter av företagande uppkom i samband med hennes första möte med professionen; inte såsom veterinär själv men som en djurintresserad flicka och obetald assistent hos en veterinär. För Sandra var starten av en enskild firma ett sätt att kunna försörja sig samtidigt som hon närmade sig sitt drömyrke genom oavlönat arbete. Sandra betonar sitt kön i dessa omständigheter men som vi kan se finns här även en åldersdimension:

Som vanligt för alla flickor som är djur- och hästintresserade så fick jag ingen lön.

Problem som kan relateras till genussystemet gjorde att Sandra då hon blivit legitimerad veterinär efter ett par år lämnade sin anställning på ett djursjukhus och istället blev lärare i djursjukvård. Sandra startade i ett senare skede återigen ett företag för att få möjlighet att arbeta enbart som veterinär. Företagandet kan tolkas som ett sätt för Sandra att återgå till professionen utan att åter utsätta sig för mönster av hierarkisering och segregering inom en organisation. Företagande som en lösning kan i Rebeccas och Sandras fall förstås i form av ett samspel mellan å ena sida genussystemet såsom en struktur och å andra sidan kvinnornas handlingsutrymme som aktörer. Genussystemets struktur inverkar på olika sätt på dessa kvinnors arbetssituation och att bli företagare kan ses som aktörernas försök att förändra sin situation (jmf Giddens, 1984) och undkomma strukturens (här genussystemets) begränsningar (Hirdman, 1988).

Företagandet beskrivs av flera intervjupersoner i denna studie som en lösning. I flertalet situationer kan valet att blir företagare relateras till en problematik vad gäller genussystemets krafter av hierarkisering och segregering. Företagandet kan ses som ett exempel på FemInc.ism, det vill säga företagandet blir en möjlig arena för handlingskraft och förändring (Ahl et al., 2016). Detta är något som jag kommer att diskutera i kommande avsnitt.

Företagande har tidigare beskrivits som en livsform, det vill säga som ett sätt att leva (Bergqvist, 2004; Holmquist \& Sundin, 2002; Lönnbring, 2003). Livsformsteorin tar utgångspunkt i att människor av olika anledningar har skilda sätt att hantera och leva sina liv. Företagande beskrivs av intervjupersonerna som en flexibel arbetsform med stort utrymme för anpassning till olika situationer. Oberoende och frihet tillskrivs särskilt stor vikt. Samtliga intervjupersoners berättelser skulle på basis av detta kunna sägas passa in i självständighetens livsform (jmf Höjrup, 1983/89). För denna livsform är just oberoende och önskan att ha kommandot över sitt eget liv tydliga kännetecken.

Företagande betonas av intervjupersonerna i denna studie främst som ett sätt att kunna vara veterinär på egna villkor. Detta blir tydligt inte minst när intervjupersonerna betonar företagande som frihet. Med frihet avser de att som företagare vara fria att välja när, hur och var de arbetar. 
Flera av intervjupersonerna relaterar återkommande $\mathrm{i}$ sina berättelser om sitt företagande till tiden då de enbart var anställda. Upplevelserna av att vara anställd respektive företagare jämförs och samtliga föredrar att vara företagare framför att vara anställd. Lenas sätt att uttrycka sig kan användas som exempel på något som framkommer både explicit och implicit i samtliga av intervjupersoners berättelser:

Ska jag jobba 53 timmar i sträck under en helg så ska jag banne mig göra det åt mig själv (skratt). Då ska jag bestämma det på egen hand.

Friheten som intervjupersonerna beskriver innebär i realiteten begränsad ledighet då valet ibland faller på att uppoffra sig till förmån för patienter och kunder i det dagliga arbetet. Ibland leder friheten till dåligt samvete vid ledighet. Att säga nej kan vara svårt och är något man lär sig menar Rebecca. Beatrice har dock svårt att komma undan sitt dåliga samvete och föredrar att spendera sin ledighet på annan ort för att undvika situationer där hon måste säga nej till kunder och patienter. Upplevelsen av frihet trots en omfattande arbetsbörda identifierade även Hellberg (1990) i sin studie av kvinnors företagande på landsbygden ur ett försörjningsperspektiv. Hon visade att omfattande arbetsinsatser med begränsad semester uppvägs av flexibilitet och känslan av frihet i arbetet. Detta är något som även framkommer i föreliggande studie; hårt arbete och uppoffringar beskrivs i samma andetag som en känsla av frihet. Att det självständiga arbetet är en större drivkraft för företagare än pengar och hög status visar även Tillväxtverket (2012a) i en undersökning.

Professionstillhörigheten och professionsutövningen framträder i intervjupersonernas beskrivning av sitt dagliga arbete som den främsta drivkraften för dem. Detta kan jämföras med Lindgren (2002) som i sin studie av lärare som startat friskolor fann att det var det pedagogiska engagemanget som var den huvudsakliga drivkraften snarare än lusten att driva företag. Friheten som företagandet för med sig för intervjupersonerna i föreliggande studie riktas mot och gagnar främst patienter och kunder men även själva professionen. Föresatsen att uppfylla samhällskontraktet och de normativa förväntningar som knyts till professionen kan ses som en del i arbetet för professionens existensberättigande (jmf Molander \& Terum, 2008). Sandra beskriver en konflikt mellan företagandet och professionen då hon företar långa bilfärder för att göra en enkel vaccination. Det hon tjänar täcker knappt kostnaderna. Sandra betecknar sitt agerande som oekonomiskt men i diskussionen med mig blir det dock tydligt att hennes agerande även kan ses som ekonomiskt rationellt på längre sikt då det handlar om att bevara ett gott rykte.

Samtidigt som intervjupersonernas företagande kan kopplas till självständighetens livsform anger flera att ytterligare en anledning till att starta eget företag är att kunna ha en rik fritid och möjligheten att värna om sig själva. Detta är ett kännetecken för löntagarlivsformen (jmf Höjrup, 1983/89). Flera intervjupersoner anpassar sina 
verksamheter och har exempelvis en ledig dag i veckan för att vila, alternativt för att sköta administration för att inte behöva arbeta övertid. Exempelvis ses en avbokad tid av flera intervjupersoner som en möjlighet till en lugn eftermiddag snarare än orsakar oro över förlorad inkomst. Att strikt skilja mellan arbete och fritid såsom denna livsform påbjuder passar dock inte med intervjupersonernas beskrivningar av det dagliga arbetet. Inte minst när en dörr är det enda som skiljer hem från företag kan det vara svårt att lägga tankarna på arbete åt sidan.

Företagandets frihet, som jag redan varit inne på, handlar för intervjupersonerna främst om en möjlighet att kunna välja hur de vill utöva sin profession. De flesta vill göra det med fokus på kvalitet gentemot både kund och patient. Detta är något som dessutom ligger till grund för allmänhetens och det politiska samfundets tillit till professionen (jmf Molander \& Terum, 2008). Kvalitet åstadkoms genom att vara tillgänglig, genom att åka hem till kund och patient, genom att vara flexibel och genom att själv välja hur, vad och när. Företagande lyfts fram som ett sätt för intervjupersonerna att kunna bestämma själva, få utlopp för idéer och anpassa verksamheten till brister som de upplevt i sina anställningar. Både Lena och Rebecca poängterar fördelen med att kunna anpassa sina verksamheter till exempelvis rädda hundar. Detta utrymme för omtanke och flexibilitet som professionella förmågor möjliggörs i och med företagandet.

En brist i veterinärsektorn som lyfts fram av intervjupersonerna är tillgänglighet för djurägarna och flera menar att de kan göra mycket för att fylla de luckor som finns vad gäller jourmöjligheter i länet. Företagandet blir på detta sätt möjliggörande för professionsutövningen samtidigt som det för individen skapas ett visst handlingsutrymme (jmf Ahl et al., 2016).

Jag kan ju säga nej nu, det kunde jag inte förut. Nu kan jag välja. Så att det har jag ju blivit lite bättre på nu men på djursjukhuset fick jag ju inte säga nej.

För Annika finns det nu även möjlighet att avvisa kunder som hon inte trivs med men även att vara tillgänglig för andra kunder dygnet runt. Det är till syvende och sist hon som bestämmer över verksamheten.

Karriärlivsformen kan främst identifieras hos de mer nystartade företagarna som Lena och Anja, vilka ger uttryck för ambitioner att ta sig uppåt och framåt. Även i denna livsform ses arbetet som ett sätt att leva men där finns också en viss strävan efter goda ekonomiska förhållanden. De intervjupersoner som kan beskrivas som gamla i gemet, som Annika och Rebecca som tillsammans har över 40 års erfarenhet som företagare, uttrycker dock snarare en tillfredsställelse i sitt företagande och är nöjda med sin arbetsbörda och ekonomiska situation. På detta sätt resonerar även Eva: 
Jag är ingen sån där som vill ha ett imperium av kliniker och jag är inte särskilt sugen på att anställa några fler människor i verksamheten heller. Jag har full styrning till vad jag orkar att göra själv så jag behöver inte öka på kundantalet. Det är rätt lagom nivå och jag trivs med det.

I sin klassificering av kvinnors företagande inkluderar Goffee och Scase (1985) könsrollsideal vid sidan av företagarideal och formade fyra typer av företagare: konventionella, innovativa, familjerelaterade och radikala. Två av dessa typer är applicerbara i denna studie; de innovativa respektive de radikala företagarna. Båda dessa kännetecknas av hög utbildning och av att de prioriterar sitt arbete/yrke framför sin fritid. De innovativa företagarna beskrivs av Goffee och Scase främst som karriärsdrivna kvinnor som delvis tar avstånd från genusproblematik och istället har en hög tilltro till individuella drivkrafter. Som vi har sett intar några av professionsföretagarna synsättet att blunda för genussystemet, som också diskuterats av Lewis (2006). I så måtto liknar dessa de innovativa företagarna som de beskrivs av Goffee och Scase (1985). De radikala företagarna beskrivs som individer som försöker undkomma underordning och som har erfarenhet av mäns fördomar från tidigare arbete i storskaliga organisationer. Exempel på den radikala typen av företagare har vi sett ovan i form av bland andra Sandra och Rebecca som efter upplevelser av diskriminering valde att starta eget. I viss mån kan dock de flesta av intervjupersonerna betecknas som radikala utifrån Goffee och Scases (1985) klassificering. Ingen av professionsföretagarna är konventionella eller familjerelaterade på det utpräglade sätt som Goffee och Scase (1985) beskriver.

Företagandet relateras av intervjupersonerna i denna studie $\mathrm{i}$ viss mån till familjesituationen. Sundin och Holmquist (1989) tog i sin pionjärsstudie inspiration från bland andra Goffee och Scases (1985) uppdelning i företagarideal och könsrollsideal och lade till familjesituation som en viktig faktor i sammanhanget.

Jag hade nog inte klarat det från början om jag inte hade haft en man som också tjänade pengar. Även om han till en början tyckte att om jag ändå hade mottagningen hemma i källaren så behövde jag ju inte ha barnomsorg. För jag var ju ändå hemma. Så smart. (Skrattar). Jag kan säkert stå och göra kejsarsnitt med en skrikande ettåring vid fötterna. Faktum är att det hände men då fick ju djurägaren vara barnvakt medan jag opererade.

Sandra beskriver ovan hur barnpassningen anpassas till förmån för utövningen av professionen. Kejsarsnittet på en hund blir gjort medan djurägaren är barnvakt. Jag ser Sandra, som ett exempel på någon som utmanar genussystemet och som skapar glipor i mönstret i sin egen vardag (jmf Fogelberg Eriksson, 2005). Hon valde att starta företag för att kunna vara veterinär på sina egna villkor och för att komma bort från att i rollen 
som anställd vara utlämnad till organisationens hierarkisering och segregering. Sandras fall visar också att företagande kvinnor kan vara både karriärsinriktade och privilegierade men ändå samtidigt marginaliserade och styrda av nödvändighet i likhet med de kvinnor som studerades av Sundin och Holmquist (1989).

\section{Landsbygdsföretagande och livsform}

Utifrån den definition av landsbygdsföretagande som används i denna studie är sju av tio intervjupersoner företagare på landsbygden. Företagarna har dock haft en annan bevekelsegrund än det försörjningsperspektiv som både Lönnbring (2003) och Hellberg (1990) lyfter fram i sina studier av kvinnors företagande på landsbygden. Flera av intervjupersonerna för fram landsbygden som en fördelaktig arena för deras företagande. De som har en inriktning mot häst har en given plats på landsbygden med tanke på de utrymmen som krävs för sådan verksamhet samt då tillgänglighetsfrågan i viss mån blir irrelevant då en klinisk undersökning antingen kräver hästtransport eller en ambulerande veterinär. De strukturella hinder för företagande på landsbygden i form av glesa marknader vad gäller utbud och efterfrågan (jmf Företagarna, 2013) baseras till stor del på en annan typ av företagande än vad som är centralt i denna studie och är därför inte tillämpliga i samma utsträckning. Evas verksamhets placering på landsbygden, men även i närheten av en travbana och mitt i ett kluster av travstall, framstår som både udda och fördelaktig då detta medger ett visst mått av möjlighet till spontana besök. Travkuskarna kan vid behov ta sina hästar i betslet och promenera bort till kliniken. Landsbygden är en traditionell arbetsplats för veterinärer och därmed även för veterinärer som är företagare.

Företagarnas inriktning mot veterinärverksamhet gör att de skiljer ut sig gentemot de områden av turism, naturresurser och livsmedelsproduktion som forskningen om företagande på landsbygden vanligen fokuserar (Waldenström \& Westholm, 2006). Ett

fåtal av intervjupersonerna har kunder med företag inriktade mot livsmedelsproduktion, exempelvis i form av mjölkbesättningar. Denna verksamhet är dock, som vi har sett, begränsad.

En stor del av den tidigare forskningen om landsbygdsföretagande kan beskrivas utifrån ett försörjningsperspektiv på företagande (Hellberg, 1990; Lönnbring, 2004) och synen på landsbygden som en plats där stereotypa genusmönster reproduceras. Även om genus till viss del förstärks i turistföretagandet genom gestaltningen av bondmoran förändras också hur genus görs då kvinnor på lantgårdar blir företagare och förändrar användningen av lantgården (Pettersson \& Heldt-Cassel, 2014). Inom forskningen om kvinnors företagande på landsbygden blir min inriktning mot 
veterinärprofessionen en annorlunda utgångspunkt. Det handlar inte om företagare på landet som går in i upplevelseturism för att kunna behålla släktgården. Det handlar heller inte om något hobbyföretagande eller om försök att skapa jobb på en döende landsbygd. Veterinärprofessionen har traditionellt haft sin bas på landsbygden.

\section{Professionsföretagande som livsform}

Intervjupersonerna ser sig som veterinärer som driver företag snarare än att vara företagare i veterinärbranschen. Christina och Rebecca säger explicit att de helst av allt vill vara veterinärer. Christina menar att företagandet handlar om ett sätt att försörja sig medan veterinärprofessionen utgör en grundpelare i tillvaron:

Jag tror att veterinärer är intresserade av veterinärmedicin och att företagandet är ett bifynd.

Självständighetens livsform skulle utifrån den här studien kunna omformas till att professionen istället för företagandet sätts i centrum. Kännetecknen skulle då utgöras av att professionen är den huvudsakliga drivkraften snarare än lönen och att det är professionsutövningen som har en tendens att flyta ihop med fritiden. Ytterligare ett kännetecken skulle vara att oberoende och frihet i utövningen av professionen tillskrivs stor vikt. Samtliga av dessa kännetecken är tydliga i studiens empiri. Även aspekter av karriärlivsformen och löntagarlivsformen, justerade utifrån professionen som det centrala framför företagandet, står att finna i intervjupersonernas berättelser. Det finns de som är mer karriärinriktade strävar efter utveckling av företaget och professionen genom att arbeta mycket, samtidigt som det finns de som i högre grad än andra skiljer mellan arbete och fritid och som ser arbetet som en förutsättning för att kunna leva.

Flera av intervjupersonerna önskar att de enbart behövde vara veterinärer samtidigt som de är nöjda med sitt företagande. Generellt sett tycks nöjdheten med företagandet kombineras med strävanden i professionen. Inte minst strävanden efter att utvecklas som veterinär. Företagandet är en viktig del av intervjupersonernas sätt att leva sina liv men det är inte dominerande i relation till professionen. Professionen utgör en större del i det som kan beskrivas som intervjupersonernas livsform än vad företagandet gör.

Benämningen intervjupersoner, som hitintills nyttjats för att referera till de tio individer som intervjuats inom ramen för denna studie, kan i sammanhanget ses som ett uttryck för ett språkligt dilemma där varken företagare eller veterinär har varit heltäckande begrepp för att beskriva dessa individer. Givet professionens och företagandets samspel där dock professionen är överordnad företagandet föreslår jag 
begreppet professionsföretagare som en lämplig benämning för denna kategori och det är detta begrepp jag kommer att använda härefter.

\section{Professionsföretagare som gör genus}

Hur görs då genus i företagande respektive profession? En teoretisk utgångspunkt i denna studie är att genus är något som ständigt görs; i interaktioner mellan människor och i relation till en viss kontext. Genus är en social konstruktion som är seglivad men möjlig att förändra (jmf Kelan \& Nentwich, 2009; Kvande, 2003; West \& Zimmerman, 1987). Professionsföretagarna gör genus i sina berättelser i form av könsmärkningar av både företagande och profession. Könsmärkning innebär att yrken, arbetsuppgifter, artefakter och tekniker arrangeras in i genussystemets krafter av hierarkisering och segregering genom att tillskrivas kön (Sundin, 1995a). Upplevelser av veterinärprofessionen såsom manligt könsmärkt visar sig i professionsföretagarnas tillbakablickar på sina liv som veterinärer. Samtidigt, som vi ska se, reproducerar professionsföretagarna själva på en normativ föreställning om professionen som förefaller vara manligt könsmärkt. Detta kan ses i skenet av att professionsepitetet i sig är präglat av manliga normer och karaktärsdrag och att flera av de klassiska professionerna traditionellt har varit manligt könsmärkta. Eva berättar om en tid då veterinären möttes med respekt och beundran av bonden. Rebecca berättar om sin tid som sommarjobbande veterinärstudent i form av ensamarbete och att vara lämnad att klara sig själv och jämför detta med en artikel hon läst om en veterinärstudent på praktik.

Den numerära feminiseringen av flertalet privilegierade professioner såsom läkare, jurister, revisorer och veterinärer har aktualiserat frågan huruvida detta kan ha en påverkan på genussystemet i positiv bemärkelse (Davies, 1996). Flera studier, bland annat en brittisk studie av revisorer indikerar dock att kvinnors underordning i enlighet med genussystemet består även i kontexten av en numerärt feminiserad profession (Marlow \& Carter, 2004). Flera av professionsföretagarna i föreliggande studie beskriver sin övergång från anställd till företagare som influerad av negativa upplevelser som kan relateras till deras kön och som givit bränsle till valet att bli företagare.

\section{Hur görs genus i företagande?}

Christina beskriver sin affärspartner som den riktiga företagaren som möjliggör för henne att enbart få ägna sig åt att vara veterinär. Det är dock Christina som är ansiktet utåt. Hon är genom sin professionsstatus mer synlig än sin affärspartner som snarare ägnar sig åt administrativt arbete i kulisserna. Min tolkning ur ett genusperspektiv är att Christinas obenägenhet att trots detta identifiera sig som företagare kan kopplas 
till företagandets manliga könsmärkning i vårt samhälle (jmf Ahl, 2006). Ytterligare ett exempel är Susanna som hänvisar till sin make som den riktiga företagaren men då på basis av att det var han som startade företaget. Samtidigt har Susanna i sin roll som legitimerad veterinär ett övergripande ansvar för verksamheten. Men i förhållande till maken som den som startade företaget blir Susanna osynlig som företagare i sina egna ögon.

Företagande är en manligt könsmärkt företeelse (Ahl, 2006; Holmquist, 2008; Sundin, 2002). I likhet med flera professioner och såsom i fallet med veterinären beskriver intervjupersonerna den typiska företagaren främst som en man, då de talar i generella termer. Detta görs explicit av professionsföretagarna bland annat genom exempel på män som goda företagare, av Christina i förhållande till sin affärspartner och av Susanna i förhållande till sin make. Christina berättar dessutom med viss beundran i rösten om en manlig kollega i länet som hade erfarenheter av företagande sedan tidigare och som köpte en veterinärklinik medan han fortfarande studerade till veterinär.

Professionsföretagarna konstruerar företagaren som en man i sina berättelser genom sina sätt att tala om både män och kvinnor. Den typiska företagaren beskrivs av flera av professionsföretagarna som en man som till skillnad från kvinnor inte skräms av företagandets krav. Det är en man med visioner. Som kontrast till detta beskriver professionsföretagarna kvinnor som grupp som försiktiga, osäkra och med huvudansvaret för familjen såsom en försvårande faktor för att kunna vara företagare. Flera av professionsföretagarna ger även uttryck för tveksamhet vad gäller den egna statusen som företagare. De beskriver sig som otypiska, ej representativa och såsom varandes företagare endast till viss del. Detta görs i jämförelse med män och mäns företagande. Företagande formuleras i flera av professionsföretagarnas beskrivningar som något som är svårt och krävande.

Professionsstatusens fördelar när det gäller att modifiera genussystemets uttryck för kvinnor som är företagare har diskuterats av Javefors Grauers (2002). Författaren såg att kvinnorna i egenskap av att tillhöra en profession samt att vara företagare blev dubbelt synliga och att detta var något som gynnade dem. Fokus för studien var företagarpar och en jämförelse gjordes mellan advokater samt ICA-handlare. I denna studie visar resultaten snarare att det är företagandet som ger professionsföretagarna möjlighet att modifiera genussystemets uttryck i professionen. Det är dock inte alltid som professionsföretagarna ser sig som företagare.

\section{Hur görs genus i profession?}

I sina berättelser ger professionsföretagarna en gemensam bild av veterinärens arbete som framför allt hårt och många gånger påfrestande. Betoningen läggs på avlivningar 
och livsmedelsproduktion och arbetet beskrivs som både illaluktande och fysiskt krävande. Detta är egenskaper som enligt Bems index förknippas med maskulinitet (Ahl, 2004). Eva menar att ett stort antal av de personer som nu antas till veterinärutbildningen (det vill säga huvudsakligen unga kvinnor) inte håller måttet:

Av dom 100 som kommer in så kanske det inte är mer än 70 som är kvar när man kommer till dom kliniska ämnena. För dom är ju helt fel, dom har ingen aning om vad veterinäryrket går ut på. Dom tycker det är äckligt att skära i döda djur.

Samtidigt som professionsföretagarnas beskrivningar av veterinärens arbete i föreliggande studie kan ses som avskräckande fungerar den även statushöjande. Det är med viss stolthet i rösten som arbetet som veterinär beskrivs som illaluktande och tufft. Implicit sägs; det här klarar inte vem som helst av, det krävs en särskild kaliber. Professionsföretagarna framhäver på detta sätt sina färdigheter i förhållande till den manliga normen. Detta sätt att beskriva kan ses som ett uttryck för veterinärprofessionens maskulina prägling i likhet med det Irvine och Vermilya (2010) fann i en studie av den amerikanska veterinärprofessionen. Författarna visade att veterinärprofessionen var en numerärt feminiserad profession med en kultur som glorifierade stereotypa maskulina aktiviteter och attityder.

Berättelserna om veterinärprofessionens upphöjda status och relaterad till hårt arbete landar så småningom i farhågor inför framtiden och frågan om dagens veterinärstudenter verkligen har det som krävs. Uteslutning baserad på kön har historiskt fungerat som en barriär för att säkra mäns tillgång till möjligheter och belöningar inom ett yrke (jmf Witz, 1992). I och med skiftet från kvinnors exkludering till inkludering i professionerna är dock kön inte längre en barriär för tillträde till professionen. Dagens veterinärstudenter (som alltså till 88 \% är kvinnor) diskuteras av intervjupersonerna främst i generella termer och ges endast i undantagsfall kön. Implicit präglas dock beskrivningarna av negativa konnotationer av det feminina. I några fall exemplifieras detta med en tillgjort feminin röst som för att understryka illustrationen av veterinärstudenterna som naiva och som formandes en romantisk bild av yrket.

I skenet av generella professionskaraktäristika kan den manliga könsmärkningen av professionen ses som ett utslag för den kåranda som är ett av kriterierna för en profession (jmf Abrahamsson, 1986). Kårandan grundar sig bland annat i att vissa kandidater sorteras bort vid rekrytering och genom utbildning. Kvinnor sorterades tidigare i veterinärprofessionens historia, som nämnts ovan, bort på grund av sitt kön redan vid inträdet till utbildningen. Professionsföretagarna ger uttryck för professionens kåranda på det sätt som de lärt sig; genom att inkludera sig själva och exkludera andra. De inkluderar sig själva på basis av, delvis, maskulina färdigheter 
och exkluderar nästkommande generation på basis av ofärdigheter som $\mathrm{i}$ berättelserna kopplas till kön. Detta sätt att inkludera sig själva och utesluta andra kan liknas vid de inneslutande strategier som utgör underordnade gruppers motreaktion mot dominanta gruppers uteslutningsstrategier, som tidigare studerats. Argument för att inkluderas baseras ofta på individualistiska kriterier som färdigheter och meriter medan könet tonas ned (Witz, 1992). Väl inkluderade i veterinärprofessionen börjar cykeln om genom att professionsföretagarna i sin tur exkluderar andra.

Professionsföretagarna uttrycker att den nya generationens studenter har sökt sig till utbildningen därför att de i första hand vill arbeta med smådjur. Om det är det som eftersöks kommer studenterna att bli besvikna menar flera av professionsföretagarna. Det spekuleras kring studenternas färdigheter och intressen i negativa termer. De har höga betyg och kommer direkt från gymnasiet. Utifrån detta betonas att studenterna snarare har erfarenheter av att plugga än av att ha sett en svinbesättning. Deras erfarenheter av djur består av att ha haft en hund eller hamster. De inger definitivt inte förtroende. På detta vis gör professionsföretagarna genus i förhållande till professionen även i form av en kvinnlig könsmärkning. Denna könsmärkning präglas dock av negativa konnotationer och en låg status och konstrueras utifrån ett motsatsförhållande till den manliga könsmärkningen.

Spekulationerna kring den nya generationen och deras karaktärsdrag är utbredda och gemensamt för dem är att feminina färdigheter och konnotationer beskrivs som negativa. Genussystemet i form av mannen som normen och kvinnan som avvikande, en uppdelning i överordning och underordning skiner i dessa spekulationer igenom. Ett flertal stereotypa föreställningar om kvinnor såväl som deras företagande står att finna i professionsföretagarnas berättelser. Flera föreställningar formuleras även utanför ramarna för profession och företagande, såsom att kvinnor i grupp inte kan hålla sams, att män är intresserade av teknik och pengar medan kvinnor är osäkra och uppoffrande. Även då kvinnligt könsmärkta karaktäristika som är positiva kommer på tal är de likväl stereotypa. Det handlar om omvårdande kvaliteter och omtanke, uppoffring $\mathrm{i}$ arbetet och för familjen samt $\mathrm{i}$ att se arbetet som ett kall. Professionsföretagarna speglar sig i den nya generationens veterinärstudenter och finner den full av brister. Samtidigt som de uttrycker oro för framtiden bekräftar de sig själva som värdiga kvinnor och veterinärer. I egenskap av legitimerade veterinärer och i termer som glorifierar det maskulina framstår professionsföretagarna i min mening som "hedersmän" (jmf Powell, Bagilhole, \& Dainty, 2009).

Försöken till kvotering till veterinärutbildningen vid SLU 2006 samt 2007 berörs i flera av intervjuerna. Professionsföretagarna lägger då betoningen på att det är viktigt med en könsbalans i professionen och särskilt på arbetsplatsen. Professionens numerära feminisering beskrivs företrädesvis som problematisk och kvinnor i grupp som besvärliga. SLU stämdes och fälldes även för att ha diskriminerat kvinnliga sökande 
till veterinärutbildningen. I statens yttrande i domen gavs följande som skäl till försöken med kvotering till utbildningen:

SLU har vid valet av underrepresenterat kön som skiljekriterium eftersträvat en förbättring av den studiesociala miljön på utbildningen. SLU har inte bortsett från förhållandena på arbetsmarknaden. Tvärtom har SLU upplevt att könsfördelningen på arbetsmarknaden utgjort ett problem. Det har varit svårt att rekrytera veterinärer för arbete med lantbruksdjur vilken kan bero på att det är fysiskt krävande. Kvinnorna har i större utsträckning valt att arbeta med häst och hund.

(Uppsala Tingsrätt, 2009-03-30)

Dessa argument; könsfördelningen som ett problem vid utbildningen och på arbetsmarknaden samt oron för lantbruksdjuren står att finna även i professionsföretagarnas kommentarer till professionens numerära feminisering. Givet hur professionens numerära feminisering berörts på utbildningsnivå är argumenten som Susanna och flera andra professionsföretagare för fram inte förvånande. Snarare kan det ses som att den manliga könskodningen av veterinärprofessionen genom t.ex. betoningen på fysiskt krävande uppgifter i statens yttrande men även inom yrkeskåren och i massmedia har anammats av professionsföretagarna och förs vidare.

Samtidigt finns det exempel där professionen diskuteras i generella ordalag med en betoning på en positiv utveckling gällande den numerära feminiseringen:

Under hela nittiotalet så var det överskott på veterinärer och sen började dom här gamla rävarna gå i pension. Många fler kvinnor kom in och dom tog ut sina semestrar, tog kompledighet, föräldraledighet - de förde vanliga liv. Så då blev det mycket bättre arbetsmarknad under 2000-talet.

Anja för som en av få fram det hon ser som positivt med skiftet i professionens könssammansättning. Hon erbjuder en alternativ syn på förändringen och öppnar samtidigt upp för en utmaning av genussystemets normer genom att beskriva professionens numerära feminisering som en positiv förändring som lett till en förbättrad arbetsmarknad.

Sammanfattningsvis konstaterar jag att män är ständigt närvarande i det empiriska materialet trots att inga män som är företagare intervjuats för denna studie. Män är dock ständigt närvarande i egenskap av att vara normen. De konstrueras både explicit och implicit i professionsföretagarnas berättelser om att vara företagande veterinärer. Vi erbjuds olika bilder av män både som veterinärer och företagare och ibland som både och. Bilderna skiljer sig åt och är mer eller mindre smickrande men har det gemensamt att de tar utgångspunkt i mannen som norm och förebild. Män 
karaktäriseras löpande i berättelserna, främst i form av goda exempel när det gäller företagande och i form av både goda och dåliga exempel vad gäller professionen.

\section{Genus görs på olika nivåer}

Vi gör alla, både män och kvinnor, genus i interaktioner med varandra och i förhållande till en viss kontext. Genus görs dels i relation till vad som anses passande enligt ett normativt beteende men kan även göras utanför normen och utmana traditionella genusstrukturer (Korvajärvi, 2003; West \& Zimmerman, 1987). Genus görs på skilda sätt av professionsföretagarna i denna studie beroende på om de tar utgångspunkt i profession och företagande generellt eller i sig själva. Detta har vi sett exempel på i föregående avsnitt. I sin studie av den amerikanska veterinärprofessionen visade Irvine och Vermilya (2010) att de diskurser som de kvinnliga veterinärerna nyttjade för att själva förstå den numerära feminiseringen var de som bidrog till att upprätthålla den maskulina normen inom professionen. Ett exempel på detta i föreliggande studie är när Lena refererar till sig själv som ovanligt "killaktig" och positionera sig själv som ett undantag från traditionella genusramar:

Det är kanske ett sätt att krossa gubbväldet också (skratt). Alltså det är inget fel på vissa av gubbarna men det är ju ändå så att man behöver på nåt sätt hålla ihop. Det är lite tråkigt, för jag har lite problem med sånt där från första början med kvinnligt och manligt. Jag har försökt att hålla mig utanför den där ramen där man ska befinna sig. Jag har nog varit ovanligt killaktig men samtidigt så tycker jag att det är viktigt. För det finns ju ändå såna problem och då måste man väl på nåt sätt göra nånting för att balansera det i alla fall. Så jag tycker att det är roligt att det finns ett nätverk.

Lena argumenterar å ena sidan för att ett nätverk för kvinnor som är företagare och veterinärer i Östergötland behövs samtidigt som hon å andra sidan framhäver sina egna maskulina färdigheter. Att på detta sätt argumentera för sin tillhörighet utifrån professionens maskulina normer kan ses som ett utslag för den strategi som Bird och Rhoton (2011) betecknar "vara en av grabbarna", det vill säga att individen anpassar sig till professionens maskulina norm. Samtidigt kan hennes kommentar om manligt och kvinnligt ses som utslag för en strategi av att "hävda neutralitet" där genussystemets uttryck delvis avvisas. Förhållandet till genussystemets varande är dock som vi kan se ambivalent och Lena vidkänns dess existens till viss del i förhållande till kvinnliga veterinärer som grupp. Att på detta sätt nyttja flera olika strategier samtidigt är inte ovanligt utan ett sätt för individen att bringa klarhet i 
diskrepansen mellan egna värderingar och faktiska omständigheter (Jmf Bird \& Rhoton, 2011).

Irvine och Vermilya (2010) visade vidare att den diskurs de kvinnliga veterinärerna nyttjade då de försökte förstå professionens feminisering skilde sig åt beroende på om de talade om kvinnor i professionen generellt eller diskuterade sin egen vardag. På ett liknande sätt diskuterar professionsföretagarna i denna studie professionens numerära feminisering och andra kvinnor på ett sätt och sina egna färdigheter och val på ett annat sätt. Jag har i denna studie valt begreppen generell och specifik för att särskilja mellan dessa två nivåer. På generell nivå stereotypiseras kvinnor som grupp utifrån mannen som norm. På specifik nivå betonas de individuella färdigheterna. En skillnad i förhållande till Irvine och Vermilyas (2010) studie är att de kvinnliga veterinärerna där bidrog till att upprätthålla professionens maskulina norm genom såväl generella som individuella diskurser. I föreliggande studie upprätthålls den maskulina normen på generell nivå medan den utmanas på specifik nivå.

På generell nivå har vi i tidigare avsnitt sett hur professionsföretagarna gör genus när de diskuterar den nya generationen veterinärstudenter. Osäkerhet och omtanke har i dessa berättelser kontrasterats mot styrka och tuffhet, egenskaper som går i linje med Bems index (jmf Ahl, 2004). Professionsföretagarna erbjuder dock även berättelser som relaterar till dem själva som individer och till deras dagliga arbete i företaget på ett alternativt sätt. Här bjuds vi på en annan bild av hur genus görs. En bild som präglas av utmaning och förändring snarare än stabilitet och tradition:

Men i alla fall så började jag jobba som distriktsveterinär och så frågade dom på hästkliniken vid travbanan om jag inte kunde komma dit och jobba. För jag gick med och auskulterade där då jag hade väldigt lite utbildning på hästsidan under studietiden. Dom hade några veterinärer där som slängde hästarna i väggen och småflickorna grät. Så dom visste ju inget om mig egentligen men dom tyckte väl att jag kanske inte var riktigt lika burdus mot kunderna.

I ovanstående citat lyfter Christina fram sig själv och sitt agerande genom att ställa det mot ett mer aggressivt beteende. Detta alternativa sätt att hantera hästarna var något som gynnade Christina men även hästkliniken.

Professionsföretagarna har i olika grad och på olika sätt själva missgynnats av att vara kvinnor i en profession där mannen är norm. Karin, en av de seniora veterinärerna berättar om en inledande skepticism inför nyexaminerade kvinnliga veterinärer på 1970-talet. En skepticism som dock lade sig när de nya bevisat sina färdigheter menar hon. Flera berättelser förekommer om hur professionsföretagarna blivit ifrågasatta som veterinärer på basis av sitt kön. Samtidigt ifrågasätter de själva nästa generation, 
inte minst på basis av deras kön. Resultatet blir att de som en gång har behövt bevisa sig värdiga nu kräver det av nästa generation.

Allt professionsföretagarna säger är dock inte enbart upphöjande av professionen. Det medges att det även finns veterinärer med negativa sidor. Dessa beskrivningar tycks dock nyttjas främst för att betona de egna positiva sidorna. Anja berättar om det som hon ser som ett problem i professionen:

Det är tyvärr ett problem bland veterinärer sen tidigare. Ganska många är ganska arroganta och förmer. I områden där det inte finns någon annan veterinär så kan man bete sig hur man vill.

I gengäld betonar professionsföretagarna att de själva försöker vara tillmötesgående, förstående, empatiska och lyhörda. Att vara medveten om sin status utan att låta den stiga åt huvudet förespråkas. Med hjälp av andra, vare sig det är oerfarna studenter eller arroganta kollegor, positionerar sig professionsföretagarna såsom värdiga individer. De sköter sitt tunga och påfrestande arbete men utan att vara nedlåtande och arroganta.

Därtill finns det ett motstånd som tar sig uttryck snarare i handling än i ord. Ingen av professionsföretagarna, som jag tolkar deras berättelser, tror egentligen att veterinärprofessionen passar män bättre än kvinnor. Jag ser det som att de genom åren har hittat sätt att parera och strategiskt föra sig inom ramen för professionen. Detta kan förstås i termer av inneslutande och avgränsande strategier såsom de diskuterats av Witz (1992) (se figur 3-3). En inneslutande strategi som tillämpas av professionsföretagarna är att framhäva sin egen legitimitet. Även en avgränsande strategi tillämpas är att nedvärdera de kvinnliga veterinärstudenternas förmågor. Många av argumenten för dessa avgränsningar bygger på traditionella föreställningar om professionen men också om kvinnor.

Genom att göra en uppdelning utifrån huruvida professionsföretagarna talar om professionen generellt eller om sig själva specifikt blir diskrepanserna i hur genus görs extra synliga. På generell nivå diskuteras professionen övergripande och i talet om bland annat den nya generationen markeras en avgränsning vad gäller tillträde till professionen. Denna avgränsning har tydliga genuskonnotationer då den diskuteras främst i relation till professionens förändring vad gäller könssammansättning. På specifik nivå diskuteras professionen utifrån individen själv. Här markeras snarare en inneslutning vad gäller tillträde till professionen (jmf Witz, 1992). Denna inneslutning baseras på individuella meriter och förtjänster i praktiken snarare än på kön. 


\section{Genus görs i olika dimensioner}

Vikten av att särskilja generell från specifik nivå framstår än mer tydligt när vi ser till dimensionerna djur och arbetsuppgifter. Dessa dimensioner kan identifieras i återkommande exempel i professionsföretagarnas beskrivningar av det som kan ses som en pågående könsmärkningsprocess $\mathrm{i}$ veterinärprofessionen. De djur som behandlas och de arbetsuppgifter som utförs kan ses som två dimensioner där genussystemets principer av hierarkisering och segregering möts och formar professionens interna segregering (jmf Einarsdóttir, 1997).

\section{Djurens könsmärkning}

Djuren är alltså en viktig del i den interna segregeringen och könsmärkningen av veterinärprofessionen. Föreställningar om, och den därtill kopplade könsmärkningen av, de djur som utgör professionens fokus är komplexa. De djur som traditionellt varit del av veterinärens arbete är lantbruksdjur och hästar. Till viss del gäller det även sällskapsdjur men då främst hunden och inte i den utsträckning som vi kan se idag.

Lantbrukets djur utgör grunden för hela professionen då det var i samband med 1700talets boskapsdöd i Europa som den första veterinärutbildningen inrättades. Dessa djur, som även benämns som "produktionens djur", gav kött, mjölk, hudar och arbetskraft och var en viktig del i samhällsekonomin (SOU, 2007:24). De var även länge veterinärens främsta källa till arbete och inkomst. SLUs argument till kvoteringen, som diskuterades i ett tidigare avsnitt, visar att lantbruksdjurens manliga könsmärkning fortfarande är stark. Flera av professionsföretagarna framhäver att de i första hand var inställda på att arbete med lantbruksdjur efter utbildningen men att det, väl ute i arbetslivet, föll sig annorlunda. Såväl Beatrice som Anja beskriver behovet av veterinärer för mjölkbesättningar som begränsat. Något som Beatrice menar kan förklaras med den förändrade djurhållningen.

Samtidigt förstärks den manliga könsmärkningen av lantbruksdjuren då professionsföretagarna på generell nivå för vidare föreställningar om unga flickor som helst vill arbeta med sällskapsdjur och som har bristande erfarenhet gällande lantbruksdjur. Sandra menar att incitamenten till kvotering var en rädsla för att ingen (läs kvinnor) skulle vilja arbeta med lantbruksdjur. Själv skrattar Sandra åt denna förklaring och menar att hon ville bli distriktsveterinär men inte fick möjlighet då hon motarbetades av en manlig distriktsveterinär. Intern segregering i form av en uppdelning av arbetsuppgifter, specialiseringar och inriktningar fördelas ofta i enlighet med stereotypa antaganden om att en viss sorts arbete lämpar sig bättre för kvinnor medan ett annat lämpar sig bättre för män (jmf Abrahamsson, 2004; Bradley, 2013; Sommestad, 1992). På detta sätt nyttjas avgränsande strategier för att kontrollera kompetensområden inom professionen (jmf Witz, 1992). 
Professionsföretagarna utmanar lantbruksdjurens manliga könsmärkning när de på specifik nivå använder sig själva som exempel på kvinnor som vill/har velat arbeta med dessa djur.

(...)men det finns ju faktiskt tjejer som är intresserade av det. Jag hade inte tänkt hålla på med smådjur. Jag ville vara distriktsveterinär men när jag var näst intill färdig då blev jag faktiskt värvad till djursjukhuset $\mathrm{i}$ Linköping.

Lantbruksdjuren minskar i landet medan sällskapsdjuren ökar och diskussionen kring vad den nya generationens veterinärer vill arbeta med tycks bygga på gamla traditionella föreställningar om såväl professionen som könen. Det är viktigt att minnas att en del i professionens särställning handlar om lantbruksdjuren och dessa har även varit del i det samhälleliga argumentet för att bibehålla professionens unika position. Olika utredningar har sedan 1970-talet genomförts och fokus har återkommande varit förslag på omorganisation av veterinärprofessionens uppdrag av ekonomiska skäl. Denna omorganisation ifråga om en privatisering av distriktsveterinärerna har dock gång på gång avvisats med hänvisning till behovet av beredskap för sjukdomsutbrott, så kallad epizootiberedskap. Lantbruksdjuren, som potentiella smittspridare, är därmed en viktig del i veterinärprofessionens existens.

I jämförelse med lantbruksdjuren och sällskapsdjuren är det hästen som är det djur som tycks åtnjuta högst status att behandla. Hästen beskrivs som ett prestigefyllt och värdefullt djur, något som även influerar hästveterinärens status. Christina med den stora hästkliniken menar att hon inte hade för avsikt att bli hästveterinär från början. Detta då hon såg dem som ouppnåeliga. Hon berättar om sin tidigare syn på hästveterinärer som en upphöjd grupp och beskriver dem i termer av intelligenta män. Även Eva menar att sinnebilden av den klassiska hästveterinären är en man, företrädesvis i 50-årsåldern. Själva är de dock båda exempel på att hästveterinären likväl kan vara en kvinna.

Könsmärkning av arbetsuppgifter och specialiseringar kan ses som en variant av avgränsande strategier som Witz (1992) ger exempel på i sin modell över strategier för yrkesstängningar. Dessa strategier används enligt Witz (1992) som ett sätt att kontrollera närliggande grupper när det gäller arbetsdelning. Könade former av avgränsningar inom en profession används för att ringa in kvinnor i en avskiljd kompetenssfär som kan underordnas mäns kompetenssfär. I detta fall kan hästen ses som manligt könsmärkt och som en utgångspunkt för avgränsningar i professionen.

Det är väldigt speciellt med en hästklinik för hästar dom är stora, dom är snabba och dom är jättefarliga. Det kräver stora utrymmen och det går inte att springa igenom lika många hästar på en dag som man springer 
igenom hundar eller katter. Det går inte att jämföra liksom. Du måste ha ett helt annat säkerhetstänkande och det kräver mycket större ytor.

Christina lyfter hästveterinärens status ytterligare genom att beskriva arbetet med hästar som riskfyllt, något som kan relateras till Bems index för manligt könsmärkta egenskaper (jmf Ahl, 2004). Hunden och katten är i jämförelse enklare att arbeta med menar Christina. Också Annika beskriver att katten erbjuder fördelar i jämförelse med andra djur då det är ett litet och behändigt djur för en ensam veterinär att arbeta med. Både Rebecca och Annika argumenterar för kattens statushöjning så som ett djur som är en stor utmaning att behandla. Inte minst då den kan vara svår att ställa diagnos på. Annika talar om diagnosticering av katter som ett detektivarbete. På en specifik nivå, med utgångspunkt från sig själv och sin verksamhet, lyfter Annika på så sätt sin egen och andra kattveterinärers status. Detta kan jämföras med hur genus görs på en generell nivå då det snarare är lantbruksdjuren som lyfts fram i jämförelse med de feminint könsmärkta smådjuren.

Professionsföretagarna gör i sina berättelser genus på generell nivå i enlighet med genussystemets krafter av hierarkisering och segregering. Detta menar jag görs delvis omedvetet samtidigt som de på specifik nivå snarare utmanar flera av dessa stereotypa föreställningar. Flera av dem är själva exempel på att kvinnliga veterinärer är intresserade av att arbeta med lantbruksdjur men ser att denna del av arbetsmarknaden har blivit alltmer begränsad. Samtidigt har försäkringsgraden för katter i Sverige ökat och är unik i världen (Agria Djurförsäkring, 2013). I realiteten utgör sällskapsdjuren generellt sett en större del av veterinärens vardagliga arbete än lantbruksdjuren.

På specifik nivå argumenterar professionsföretagarna för en alternativ syn på djuren. Flera berättar om föreställningar om hästens manliga könsmärkning som de har mött under sina arbetsliv men i egenskap av att själva ha trotsat dessa föreställningar är de också exempel på att denna könsmärkning inte är huggen i sten.

\section{Arbetsuppgifternas könsmärkning}

Även de arbetsuppgifter som veterinären ägnar sig åt i sin verksamhet en viktig dimension vad gäller hur genus görs. Principen om mannen som norm i veterinärprofessionen och kvinnan som den avvikande medför att det som betecknas som mannens arbetsuppgifter generellt ges en hög status medan kvinnors arbetsuppgifter generellt ges en låg status. Även inom läkarprofessionen har kirurgi en hög status och mannen var under lång tid sinnebilden för en kirurg. I professionsföretagarnas tal om kirurgi märks även i denna studie en upphöjd ställning för denna arbetsuppgift. Kirurgi kan här liksom djurslag ses som del i ett större sammanhang av avgränsningar mellan olika fält inom professionen som fungerar som 
internt segregerande (jmf Witz, 1992). Kirurgi lyfts av samtliga professionsföretagare fram som en av de viktigaste och mest statusfyllda arbetsuppgifterna inom veterinärprofessionen. Kirurgi jämförs då främst med medicinska utredningar. Einarsdóttir (1997) menar att avgränsningar mellan olika fält uppstår som en följd av en intern trängsel på grund av en ständigt pågående specialisering och utvidgning av kunskap. Könsmärkning av arbetsuppgifter blir en viktig utgångspunkt för avgränsningarna inom professionen.

Denna könsmärkning av kirurgi har professionsföretagarna på olika sätt fått erfara under sin tid i veterinärprofessionen. Rebecca berättar om mötet med en man som var veterinär som förde fram åsikten att män skulle ägna sig åt kirurgi och kvinnor åt medicinska utredningar. Rebecca förkastar detta påstående och menar att det är männens vassa armbågar som ger dem tillträde till operationssalen. Både Sandra och Rebeccas motiverar sina val att starta företag som delvis grundade i denna erfarenhet. Sandra berättar om en förändrad situation på arbetsplatsen när hon kom tillbaka från sin föräldraledighet:

(...)då hade ju dom här killarna kommit och pinkat in sina revir. Så då var man mest i vägen. Näe, jag kunde nog ingenting. Så då fick jag inte operera plötsligt, men på jourerna skulle jag operera - fast egentligen var jag tvungen att ringa någon bakjour då för jag kunde nog egentligen inte i alla fall.

Ovanstående är ett exempel på flexibilitet i utestängning av kvinnor från vissa arbetsutgifter. I detta fall gällde det kirurgi, men det kan liknas vid flexibiliteten i utestängningen från vissa arbetsuppgifter inom jordbruket under delar av 1900-talet (jmf Flygare \& Isacson, 2003). När kvinnorna verkligen behövdes tilläts de utföra arbetsuppgifter som annars var förbehållna männen. Utestängningen från operationssalen blev sedermera det som förde Sandra bort från djursjukhuset, via en lärartjänst, till företagandet. I Rebeccas fall handlade det mer om en känsla av att hennes kirurgiska talang inte uppmuntrades i samma utsträckning som männens vid djursjukhuset där hon arbetade. Inkluderingen av kvinnor i professionen kan på detta sätt ses som begränsad. Samtidigt som det finns ett behov av arbetskraften så marginaliseras, exploateras och nedvärderas kvinnors arbete (jmf Bolton \& Muzio, 2007).

Genus görs alltså i relation till kirurgi dels i professionsföretagarnas berättelser om problem och motgångar, dels i deras berättelser om lösningar och alternativa perspektiv. Professionsföretagarna talar med utgångpunkt i sig själva om kirurgi som något de tycker är roligt och intressant, som de saknar att utöva eller som de vill lära sig mer om. Kirurgi betonas som något eftersträvansvärt. Eva har pendlat mellan företagande och anställning, till viss del på grund av sitt intresse för kirurgi: 
Det hade ingenting med firma eller anställda att göra utan det hade att göra med att jag ville göra andra arbetsuppgifter och lära mig lite mera. Jobba lite mer med kirurgi. Då måste man kunna söva och det kan man inte göra ensam ute i fältet utan det måste man göra på en klinik.

Efter tio år som anställd vid en hästklinik valde Eva att återgå till företagande igen. Både Eva och Christina utmanar kirurgins statussymbol genom att lyfta fram alternativa perspektiv på sitt dagliga arbete. Båda företagarna har en inriktning mot häst i sina verksamheter, ett djur som vi sett redan har en förhållandevis hög status i veterinärprofessionen. Ingen av dem har dock möjlighet att utöva kirurgi inom ramen för sina respektive företag. Eva lyfter som en motpol till kirurgi fram hältutredningarnas fördelar som spännande och varierat arbete. Christina betonar å sin sida kirurgins potentiella monotoni:

Fast för mig ligger ju utmaningen i att hitta stället som ska opereras och inte att stå och göra samma sak varje dag. Det är inte spännande nog för mig.

Ett annat sätt att argumentera kring kirurgins status är att lyfta fram den professionella etiken. Möjligheter till kirurgi i verksamheten avfärdas då på basis av patientsäkerhet och kvalitet. Lena berättar:

Jag utför faktiskt nästan det mesta som går att göra på hundar och katter som inte kräver en operationssal eller liknande. Det vet jag att vissa veterinärer gör hemma, alltså opererar djur i magen på ett köksbord, och det ligger jättelångt ifrån min moral och vad jag kan tänka mig att göra. (...) Det finns ju veterinärer som agerar på helt andra sätt som kastrerar katter ute i ladugårdar. Men jag är inte född på det sättet kan man säga och jag vill inte sänka på den standarden. Jag vill ju ändå kalla mig för hund- och kattveterinär, smådjursveterinär. Då vill jag hålla den kvaliteten på det hela. Det är ändå en ökad risk för komplikationer. Det är inte etiskt försvarbart tycker jag.

Min tolkning är att professionsföretagarna hanterar det faktum att de inte ha möjlighet att utöva kirurgi inom ramen för sina verksamheter genom att tona kirurgins betydelse och uppvärderar annat arbetet men även betona professionell etik.

Den senare delen av diskussionen sammanfattas nedan i en matris som illustrerar hur genus görs på olika nivåer och i olika dimensioner. Citat från resultatkapitlen har infogats i matrisen i syfte att synliggöra hur genus görs. Dessa citat sätts i sitt sammanhang i efterföljande text. På en generell nivå, det vill säga när professionsföretagarna tar utgångspunkt i professionen görs genus enligt stereotypa föreställningar. Här finns dock utrymme för såväl stabilitet som förändring i förhållande till genussystemets struktur, då professionsföretagarna på en specifik 
nivå, med utgångspunkt i sig själva för fram alternativa perspektiv och argument vad gäller både djurslag och arbetsuppgifter.

\section{Dimension}

\section{Djurslag}

Arbetsuppgifter

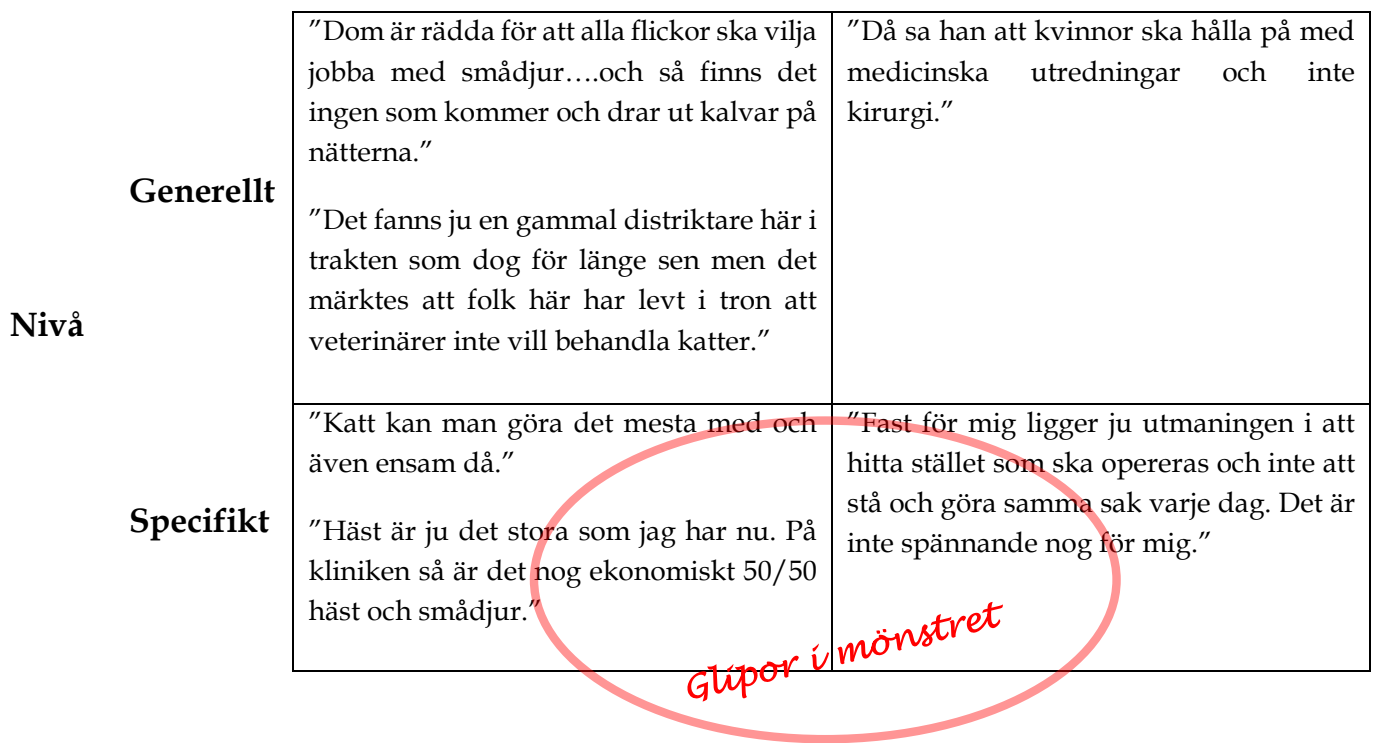

Figur 9-1: Att göra genus; nivåer och dimensioner (veterinärer)

Generellt/Djurslag: Citaten illustrerar hur djurslagen könsmärks på generell nivå utifrån professionens traditionella synsätt på djur. I det första citatet kommenterar Sandra försöken till inkvotering av män på veterinärutbildningen. Kon könsmärks som manlig och av stor vikt för professionen i jämförelse med de kvinnligt könsmärkta smådjuren. I det andra citatet berättar Rebecca om hur influenserna från en manlig distriktsveterinär som vägrat behandla katter levde kvar som en allmän föreställning bland djurägarna i trakten där hon etablerat sitt företag. Katten könsmärks som opassande för veterinärer att arbeta med.

Generellt/Arbetsuppgifter: Citatet illustrerar hur arbetsuppgifter könsmärks på generell nivå. I citatet berättar Rebecca om ett möte med en manlig veterinär. Kirurgi könsmärktes av mannen som manligt och som en opassande arbetsuppgift för kvinnor. Istället tilldelade mannen medicinska utredningar som passande arbetsuppgifter för kvinnor. 
Specifikt/Djurslag: Citaten illustrerar hur professionsföretagarna på specifik nivå uppvärderar sig själva, sina verksamheter och djuren de behandlar. I det första citatet framhåller Rebecca kattens fördelar. I det andra citatet framhäver Beatrice hästen och smådjuren som lika lönsamma i hennes verksamhet.

Specifikt/Arbetsuppgifter: Citatet illustrerar hur professionsföretagarna på specifik nivå uppvärderar sina verksamheter och arbetsuppgifter. Christina beskriver varför hon valt att inte ägna sig åt kirurgi i sin verksamhet. Här uppvärderar hon funktionsutredningar som ett mer spännande och utmanande arbete än att operera leder hela dagarna. På detta sätt tas udden av den manligt könsmärkta kirurgin och de arbetsuppgifter som på generell nivå beskrivs som kvinnliga uppvärderas. 


\section{Kapitel 10}

\section{Slutsatser och fortsatt forskning}

$\mathrm{V}$ I har nu kommit till avhandlingens sista kapitel. Här diskuterar jag de övergripande slutsatser som jag drar av studien i relation till de frågeställningar som formulerades i inledningskapitlet. Därefter ger jag förslag till fortsatt forskning. Först kan det dock vara på sin plats att åter erinra om studiens syfte samt preciserade frågeställningar.

Syftet med denna studie har varit att beskriva och analysera kvinnors företagande inom en profession stadd i förändring utifrån vad som sker i skärningspunkten mellan småföretagande, profession och genus. Specifikt analyseras hur genus görs bland företagare som är kvinnor och medlemmar av en profession stadd i förändring.

Hur yttrar sig samspelet mellan företagande och profession?

Hur görs genus i företagande respektive profession?

Hur påverkar förändringar inom profession och företagande hur genus görs?

\section{Hur yttrar sig samspelet mellan företagande och profession?}

Då varken professionsbenämningen - som exempelvis veterinär eller läkare - eller ordet företagare är begrepp som fångar vad det innebär att vara företagare inom en profession, föreslår jag att begreppet professionsföretagare används för den här kategorin. Begreppet avser att synliggöra samspelet mellan företagande och profession, där professionen är grunden och prioriteras. Föreliggande studie har visat att professionen, i detta fall veterinärverksamheten och dess normer, i många avseenden får prioritet framför företagandet. Då det professionsspecifika visat sig så framträdande i företagarnas sätt att tala om sitt företagande, menar jag att 
professionsföretagare bör ses som en särskild kategori av företagare. Det är centralt för både forskning, policy och stödfunktioner kring småföretagande att förstå att den här typen av företagande styrs utifrån, och i förhållande till, professionsvillkor.

Det är företagandets frihet i relation till, och med utgångspunkt i, professionen och professionsutövningen som lyfts fram i analysen av professionsföretagarna. Företagandet har för flera av professionsföretagarna fungerat som en lösning på problem och hinder som uppstått för dem som kvinnor då de varit anställda i genderiserade organisationer. Företagandet har uppkommit i strävan efter självständighet i professionsutövningen. Detta resultat är i enlighet med de studier som visar att de vanligaste skälen till att vilja bli företagare är möjligheten till självständigt arbete och att förverkliga idéer (jmf Tillväxtverket, 2012a). Den här studien har bland annat visat att det är de starka maskulina normerna i professionen som kvinnorna har sökt självständighet från och lyckats få viss distans till, genom sitt företagande.

Att anlägga ett livsformsperspektiv på företagande synliggör företagande som ett sätt leva. Genom att se företagande som ett uttryck för självständighetens livsform framhävs ett alternativ till den ekonomiskt rationella människan. Det leder oss en bit på vägen att förstå de studerade professionsföretagarna. Denna studie visar dock att drivkraften och grunden till företagandet tar utgångspunkt i strävan efter självständig professionsutövning. Här uppstår en diskrepans i förhållande till livsformsteorins syn på företagande som ett sätt att leva. Företagandet är för professionsföretagarna ett medel för att utöva professionen på egna villkor. Detta innebär att det snarare är professionen än företagandet som kan ses som ett sätt att leva. Därför anser jag att professionsföretagare är ett lämpligt begrepp att inkludera i livsformsteorin.

Även befintlig forskning om landsbygdsföretagande leder oss en bit på vägen, men inte ända fram, i förståelsen av de studerade professionsföretagarna. Landsbygden utgör utgångspunkt för majoriteten av de studerade verksamheterna och att vara företagare på landsbygden kan i sig ses som en livsform (Jmf Lönnbring, 2003; Sundin \& Holmquist, 1989). I forskningen beskrivs dock landsbygdsföretagande övervägande ur ett försörjningsperspektiv där landsbygdsboendet står i centrum och företagandet är en lösning för att kunna försörja sig i ett marginaliserat lokalsamhälle med dålig infrastruktur och få arbetstillfällen (Jmf Hellberg, 1990; Lönnbring, 2003). Landsbygdsföretagande har främst studerats i anknytning till areella näringar men på senare år även turism (Jmf Sundin, 2009; Waldenström \& Westholm, 2006). Den här studien och dess analys av profession och företagande erbjuder ett kompletterande perspektiv på landsbygdsföretagande som livsform. För en viss typ av professionsföretagande, så som inom veterinärprofessionen, kan placeringen på landsbygden vara både praktisk och strategisk. 


\section{Hur görs genus i företagande respektive profession?}

Redan i avhandlingens inledning konstaterades att kvinnor som är företagare inom en manligt könsmärkt profession är avvikande i dubbel bemärkelse. Som vi har sett i de empiriska avsnitten framträder detta tydligt även i professionsföretagarnas berättelser. Genom sitt sätt att förhålla sig till detta är professionsföretagarna också delaktiga i att göra genus. Som vi såg i analyskapitlet bidrar de både till att reproducera och utmana könsmärkningar. I den här avhandlingen har jag visat att professionsföretagarna gör genus på olika nivåer, samt i olika dimensioner i relation till profession och företagande (se figur 10-1).

\section{Nivåer}

Det rådande genusmönstret reproduceras på generell nivå medan det utmanas på specifik nivå. Med generell nivå menar jag uttalanden som intervjupersonerna gör kring profession, företagande och kön på ett allmänt plan. Med specifik nivå menar jag de uttalanden som intervjupersonerna göra om sin egen konkreta situation. Som vi ska se kan diskrepansen mellan hur genus görs på dessa båda nivåer delvis förstås och beskrivas i relation till företagandets roll.

Genus görs på generell nivå av professionsföretagarna när de diskuterar kvinnor som grupp utifrån traditionella föreställningar om könen där mannen är norm. Detta gäller såväl i förhållande till profession som företagande. Det maskulina upphöjs av professionsföretagarna som en norm samtidigt som det feminina tillbakavisas som avvikande och oprofessionellt. Med tanke på att veterinärprofessionen har genomgått en så kraftig numerär feminisering kan det ses som både anmärkningsvärt och särskilt intressant. Det går i linje med den forskning som visar att numerärt feminiserade professioner även fortsatt präglas av maskulina normer (Irvine \& Vermilya, 2010) samt att det underläge som det innebär att vara kvinna och företagare till viss del består även i kontexten av en profession (Marlow \& Carter, 2004). Resultatet blir även ett inlägg i den vidare debatten om huruvida professioners feminisering inverkar på genussystemet i positiv bemärkelse (Bottero, 1992; Davies, 1996) eller endast innebär att exkludering byts mot inkludering; i form av intern segregering och exploatering (Bolton \& Muzio, 2007; Walby, 1986). Styrkan i en professions könsmärkning blir här synliggjord och likaså företagandets, då det maskulina i verksamheten upphöjs samtidigt som det egna företagandet förminskas i jämförelse. Detta innebär att företagandets manliga könsmärkning reproduceras.

Samtidigt visar denna studie att genus görs även på specifik nivå genom att professionsföretagarna framhäver sina verksamheter och genom att de uppvärderar sig själva och sina feminint kodade färdigheter utifrån alternativa synsätt vad gäller traditionella och normativa föreställningar i både företagande och profession. 
Exempelvis framhävs egenskaper som flexibilitet och omtanke som fördelar i konkurrensen om kunderna (se analysen s. 139). Detta är delar av professionsutövningen som uppfattas som centrala av professionsföretagarna, men som inte varit möjligt som anställd i en organisation präglad av manlig könsmärkning. På detta sätt utmanas både företagandets och professionens traditionella könsmärkning i den dagliga verksamheten.

\section{Dimensioner}

Som framgått av analysen blir det tydligt i det studerade fallet att genus görs huvudsakligen i relation till profession. Jag tolkar det som en följd av att profession utgör grunden för professionsföretagarna. Studien visar vidare att genus även görs i olika dimensioner inom professionen. Intern segregering inom en profession är ett fenomen som tidigare påvisats av bland andra Einarsdottir (1997) samt Bolton och Muzio (2007). I denna studie har jag gått steget längre och visar att görandet av genus skapar intern segregering i de båda dimensionerna subjekt/objekt och arbetsuppgifter. Dessa dimensioner är en del i det övergripande mönstret av hur genus görs och via dessa både befästs och utmanas genussystemet.

Vad gäller subjekt/objekt visar studien att vissa av dessa könsmärks som manliga medan andra könsmärks som kvinnliga. Där skulle subjekten kunna handla om olika patientgrupper. I den studerade veterinärprofessionen är detta något som fått konsekvenser även i utbildningssystemet i form av ett försök till inkvotering av män till utbildningen (se s. 150), då beslutsfattare uttryckt en farhåga att det annars skulle komma att saknas professionsutövare specialiserade på vissa manligt könsmärkta subjekt/objekt. Beroende på vilken typ av profession det handlar om så kan det vara mer korrekt att tala om objekt (vid T-profession) och i andra fall subjekt (vid Lprofession) (Hellberg, 1999). Läkarprofessionen är ett exempel på en L-profession där kunskap om det levande är centralt och där klienten utgörs av människan.

Vad gäller arbetsuppgifter ges kirurgi en manlig könsmärkning och därmed upphöjd status gentemot det kvinnligt könsmärkta arbetet med medicinska utredningar. Samtidigt tonar professionsföretagarna ned kirurgins betydelse på specifik nivå. Här betonas snarare variation, utmaningar men även etik och kvalitet som mer värdefullt.

Hur genus görs i professionsföretagandet på olika nivåer och i olika dimensioner illustreras i nedanstående figur: 


\section{Dimension}

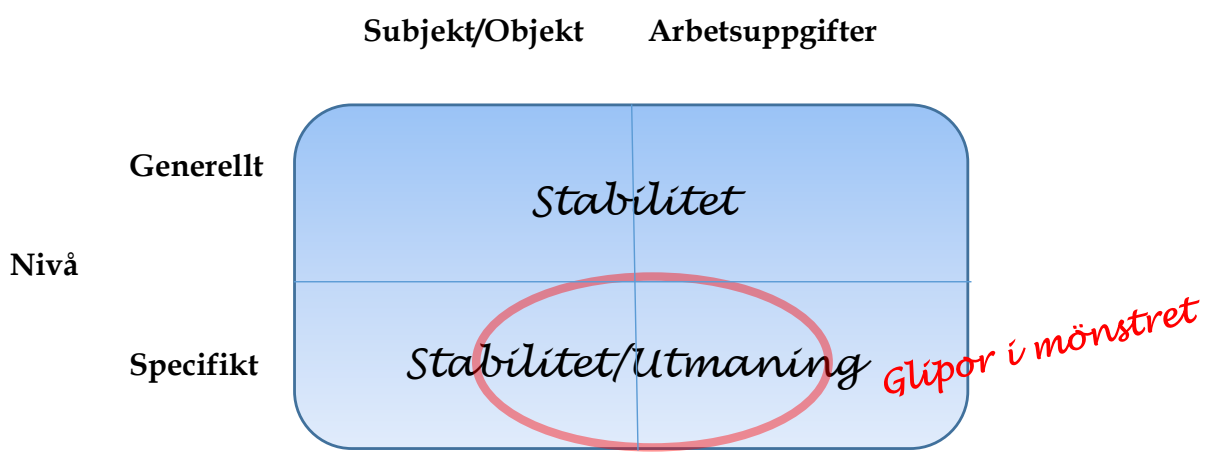

Figur 10-1: Att göra genus; nivåer och dimensioner

Även om professionsföretagarna huvudsakligen gör genus i relation till profession framkommer också hur de gör genus i relation till företagande både explicit och implicit. Företagande som fenomen beskrivs som mycket krävande och i förhållande till detta framhävs manliga företagare som goda exempel såsom varandes visionära och handlingskraftiga. Det rådande genusmönstret reproduceras på detta sätt när mäns företagande upphöjs som en norm i jämförelse med kvinnors företagande. Flera gånger ställs mannen som företagare i form av goda exempel mot kvinnan som företagare såsom avvikande. Professionsföretagarna beskriver sig själva och kvinnor i allmänhet i ordalag av osäkerhet, försiktighet och i vissa fall som otypiska. Detta görs samtidigt som de själva i egenskap av småföretagare, i flera fall med många års erfarenhet, kan ses som både förebilder och framgångsrika företagare. Mönstret av dimensioner och nivåer är inte lika framträdande i relation till företagande som i relation till profession.

\section{Hur påverkar förändringar inom profession och företagande hur genus görs?}

Förändringar i form av en numerär feminisering har inte influerat hur genus görs i relation till den aktuella professionen i så stor utsträckning. Trots den ökande andelen kvinnor inom professionen upprätthålls manligt könsmärkta normer. Resultaten av denna studie stödjer därmed den forskning som visar att den organisation eller profession som numerärt domineras av kvinnor inte nödvändigtvis behöver präglas 
av en korresponderande kvinnlig kultur (Acker, 1990; Britton, 2000; Irvine \& Vermilya, 2010). Som beskrivits ovan gäller detta i synnerhet på generell nivå.

På specifik nivå blir det däremot tydligt att förändringar i profession och företagande inte går obemärkta förbi. Att bedriva sin professionella verksamhet i företagsform gör det möjligt för kvinnor som är medlemmar av en profession att få en viss autonomi i sitt yrkesutövande, och en distans till de maskulina normerna inom professionen som varit dominerande på tidigare arbetsplatser.

Företagandet har alltså påverkat görandet av genus genom att det möjliggjort för professionsföretagarna att utöva sin profession mer självständigt samt att se på (och tala om) professionen på ett sätt som utmanar traditionella maskulint könsmärkta normer. Därigenom skapas vissa glipor i genussystemets annars så konsekventa mönster.

De intervjuade professionsföretagarna uppvärderar professionella förmågor som omtanke och flexibilitet, samt kvinnligt könsmärkta subjekt/objekt och arbetsuppgifter. Flera kan dessutom utföra manligt könsmärkta arbetsuppgifter men även mer generellt ägna sig åt en typ av verksamhet inom ramen för sitt företagande som de inte hade möjlighet att göra som anställda. Annorlunda uttryckt visar studien att företagandet är en förutsättning för diskrepansen mellan nivåerna som beskrivs ovan. Vid just den tidpunkt då studien genomfördes, på just den plats där den genomfördes, fanns utrymme för viss handlingsfrihet för professionsföretagandet. Det kan ses som ett exempel på det Ahl et al (2016) kallar FemInc.ism, d.v.s. att företagandet blev ett medel som ledde till social förändring i termer att glipor i genusmönstret. Sådan förändring var en oavsedd konsekvens av just professionsföretagandet.

Vidare bör påpekas att det handlingsutrymme som skapas för professionsföretagarna är begränsat även av företagandets villkor. Handlingsutrymmet beror alltså på situationen på marknaden. I det studerade fallet fanns vid 2010-talets början, i Östergötland, ett visst utrymmer för småskalig veterinärverksamhet. Som vi ska återkomma till nedan krävs fortsatt forskning vid en senare tidsperiod och på andra platser, för att utröna om detta varit ett specialfall i tid och rum. Vad händer med handlingsutrymmet inom kvinnors företagande när de stora bolagen och riskkapitalet nu i ökande grad går in i branschen?

Resonemanget illustrerar att genus görs dels i relation till de traditionella förhållandena inom profession och företagande och dels i relation till de aktuella förändringarna (numerär feminisering, ändrad djurhållning samt ökat företagande). Det gamla möter det nya i det ständiga görandet av genus, profession och företagande. Förändringarna i profession och företagande ger förutsättningar för att skapa glipor i genussystemets mönster, vilket i sin tur påverkar både professionen och företagandet. 


\section{Avhandlingens bidrag}

Den här avhandlingen bidrar till kunskapsbildningen om småföretagande, kvinnors företagande och profession genom att beskriva och analysera kvinnors företagande i skärningspunkten mellan företagande, profession och genus. Genom att belysa och diskutera hur dessa olika områden påverkar och påverkas av varandra bidrar avhandlingen till flera kunskapsfält.

Utgångspunkten för studien var kunskapsfältet kring kvinnors företagande. Där bidrar studien med att påvisa vikten av professionen som kontext och i hur hög grad företagandet påverkas av professionen, men även hur genus görs i profession och företagande. Kontextens roll för kvinnors företagande har tidigare uppmärksammats (Ahl, 2006; de Bruin, Brush, \& Welter, 2006) och fokuseras även i en nu aktuell bok från Diana-gruppen (Diaz-Garcia et al., Kommande). Den här avhandlingen bidrar till den pågående diskussionen genom att belysa just professionskontextens avgörande betydelse för kvinnors företagande.

Bidraget som rör professionskontextens betydelse för småföretagandet och dess villkor torde inte vara begränsat till kvinnor som företagare. Jag myntar begreppet professionsföretagare, som kompletterar existerande teoribildning kring företagande som livsform. Tidigare studier om företagande som livsform fokuserar självständighet, familj och/eller livet på landet. Den här studien visar att professionsutövningen som sådan kan vara det viktigaste för företagaren.

Forskningsfältet som rör hur genus görs i professioner har tidigare belyst att genussystemet tenderar att reproduceras inom en profession genom intern segregering (Bolton \& Muzio, 2007; Einarsdóttir, 1997). Mitt bidrag till denna teoribildning är att visa att genus kan göras på olika sätt på olika nivåer och i olika dimensioner. Jag menar att matrisen kan användas för framtida analyser av hur genus görs, då uppdelningen utifrån nivåer och dimensioner möjliggör att se inte bara genussystemets reproduktion utan även möjligheter till förändring. Den detaljerade analysen av den interna segregeringen inom professionen har också visat hur företagandet påverkas i termer av valt kundsegment och specialisering.

Som framgår framförallt av svaren på den tredje forskningsfrågan så möjliggjorde företagandet vid den tid och plats som studien genomfördes viss förändring av hur genus görs. Huruvida det ökande företagandet inom professionen över tid kommer att fortsätta göra detta möjligt är fortfarande en öppen empirisk fråga, som kan antas bero på marknadsförutsättningarna och framtida fördelning av kunder och vinstpotential mellan små och stora företag. Den numerära feminiseringen inom professionen däremot, visade sig inte påverka hur genus gjordes. På generell nivå gjordes genus fortfarande enligt traditionella manliga mönster även av de intervjuade 
kvinnorna. Härvidlag är min tolkning att småföretagandet som organisatorisk form hade större påverkan på gliporna i mönstret än den numerära feminiseringen av professionen. Nedan sammanfattas studiens bidrag i relation till forskningsfrågorna i en tabell (10-1).

\section{Tabell 10-1: Sammanfattning av avhandlingens bidrag för respektive forskningsfråga}

\begin{tabular}{|c|c|}
\hline Forskningsfråga & Bidrag \\
\hline $\begin{array}{l}\text { Hur yttrar sig samspelet mellan företagande } \\
\text { och profession? }\end{array}$ & $\begin{array}{l}\text { Begreppet professionsföretagare utvecklas } \\
\text { baserat på analysen av de intervjuade för att } \\
\text { visa professionskontextens betydelse och } \\
\text { professionsföretagande som en särskild } \\
\text { livsform. }\end{array}$ \\
\hline
\end{tabular}

Hur görs genus i företagande respektive profession?
En matris utvecklas för detaljerade analyser av hur den interna segregeringen inom professioner skapas/görs.

Matrisen illustrerar att genus görs både på generell och specifik nivå samt i relation till subjekt/objekt och arbetsuppgifter.

Användande av matrisen för framtida analyser kan synliggöra diskrepanser mellan hur genus görs i de olika dimensionerna.

Numerär feminisering påverkar inte görandet av genus på generell nivå.

Företagandet möjliggör glipor i mönstret av hur genus görs vid den studerade tiden och platsen. 


\section{Praktiska implikationer}

Studien har också relevans för policy och praktik på flera nivåer och områden.

Policy som rör kvinnors företagande har en tid varit inriktad på förebilder och ambassadörer för kvinnors företagande. Policy kring offentlig sektors omvandling har också varit inriktad, i alla fall retoriskt, på att underlätta för kvinnor att starta företag. Trots detta visar den här studien att de maskulint könsmärkta normerna påverkar professionsföretagandet. Det indikerar att en god policy för kvinnors företagande, liksom för ett ökat och breddat professionsföretagande, vore att fokusera på en förändring av genussystemet. Att integrera utbildning i genussystemet och hur genus görs i såväl företagarutbildningar som professionsutbildningar av olika slag är en stark policyrekommendation som kommer av denna studie.

Policy för kvinnors företagande, och policy för småföretagande och näringslivspolitiken bör också bevaka hur olika marknader utvecklar sig i termer av handlingsutrymmet för företagarna. Den här studien har visat att det finns ett litet handlingsutrymme för kvinnor som var professionsföretagare då studien genomfördes. Att bevaka vad som sker med detta handlingsutrymme över tid förefaller vara en viktig angelägenhet för näringslivspolitik likaväl som jämställdhetspolitiskt. Skulle utrymmet minska i takt med ökad konkurrens från riskkapitalbolag (se vidare om detta i epilogen) bör regleringar övervägas.

Resultaten av denna studie manar till viss försiktighet i tolkningar av vad en professions numerära feminisering innebär. Inom den studerade veterinärprofessionen har inkvotering av män i utbildningen varit aktuell, och en rädsla för avprofessionalisering har dryftats. Det förefaller utifrån denna studie inte som om ökningen av antalet kvinnor inom professionen är något reellt problem som skulle kunna leda till brist på veterinärer för de stora djuren. Sådana föreställningar tycks i hög grad grundade på traditionella värderingar och tankesätt inom professionen. Det förstärker slutsatsen att kunskap och kännedom om genussystemet och dessa värderingar är viktigt att förmedla till blivande veterinärer. En stor del av den reproduktion av genussystemet som professionsföretagarna själva bidrar till grundar sig enligt min tolkning på föreställningar som internaliserats under studietiden, men även fortsatt i socialiseringen som medlemmar av professionen, och som de inte har verktyg för att problematisera.

Studien visar även på implikationer för professionsföretagare, inte minst gällande den delikata balansen mellan profession och företagande. På många sätt kan professionsföretagande tyckas enkelt då verksamhetens inriktning är given och det finns en begränsning $i$ fråga om konkurrenter till den egna professionen. Samtidigt är det viktigt att hålla i minne den specifika professionens förutsättningar i form av 
exempelvis etiska regler. Professionsföretagande kan dock även ses som en möjlighet att göra saker annorlunda.

\section{Förslag till fortsatt forskning}

Det finns fortfarande mycket att göra vad gäller studier av kvinnors företagande. Studier som synliggör nyanser och tar hänsyn till en mångfald av kontexter är av stor vikt för att visa på både möjligheter och begränsningar för kvinnors företagande. Villkor och förutsättningar reproduceras, som vi har sett, delvis i företagandet. För att förstå detta behövs fler studier av såväl stabilitet som förändring vad gäller genussystemet. Studier av såväl rurala som urbana kontexter men även i relation till andra professioner är nödvändiga för att skapa en rikare bild av de processer som äger rum i skärningspunkten mellan småföretagande, genus och profession.

I den aktuella skärningspunkten, där de studerade professionsföretagarna verkar, görs genus i företagande och profession simultant. När professionsföretagarna i sina berättelser gör genus så gör de också profession och företagande. Den här avhandlingen, som tog sin utgångspunkt i kvinnors företagande, har fokuserat mest på att analysera hur genus görs. Materialet hade också kunnat användas för att mer explicit analysera hur profession görs, liksom hur företagande görs. Framtida forskning skulle kunna analysera detta eller dylikt intervjumaterial i termer av $\mathrm{t}$ ex "entrepreneuring" (Steyaert, 2007).

Då de empiriska studierna för denna avhandling genomfördes var det främst andelen kvinnor inom professionen som hade förändrats. I skrivande stund förändras förutsättningarna på marknaden. En trend, såväl internationellt som i Sverige, vad gäller företagande är att små oberoende praktiker ersätts av stora företagskedjor- som främst är inriktade mot att arbete med sällskapsdjur såsom exempelvis hund och katt (Henry, Baillie, \& Treanor, 2010; Lövgren, 2012).

Tidigare studier från Storbritannien (Treanor \& Marlow, 2016) har visat att genussystemet, likt i andra branscher (Sköld, 2015; Sundin \& Tillmar, 2010a) reproduceras i företagandet då en sådan utveckling sker. Vad händer med de glipor i genusmönstret som småföretagandet nu möjliggör? Kommer gliporna att kunna kvarstå? Eller blir kanske kvinnornas företagande marginaliserat på så sätt att kvinnorna hänvisas till att göra det de privata djursjukhusen inte finner lönsamt, som att vaccinera hästar på landsbygden? Eller, baserat på trenden av djurens status som en familjemedlem, blir det en motreaktion från kunderna vad gäller de opersonliga djursjukhusen i form av önskan om ett individuellt och personligt bemötande? Till vilken grad är en sådan motreaktion möjlig? Blir det djursjukhusens huvudsakliga 
uppgift att operera och småföretagarnas att vara serviceinriktade? Hur skulle det påverka villkoren för kvinnors företagande i branschen och inom professionen?

Ännu mer specifikt, vore en studie av hur genus görs i relation till objekt (se figur 101) i veterinärsektorn mycket intressant. Utifrån professionens tradition har lantbruksdjuren fortfarande en maskulin könsmärkning och hög status, medan sällskapsdjuren är kvinnligt könskodade och har lägre status. Utifrån ett företagsekonomiskt perspektiv är värderingen i högre grad den omvända. Det är sällskapsdjuren i form av hundar och katter som genererar vinst. Hur genussystemets hierarkiseringsdimension utvecklas i framtiden torde därför bero på om man tar utgångspunkt i professionen eller företagandet. Kommer den ekonomiska logiken och den förändrade djurhållningen att påverka vad som inom veterinärprofessionen betraktas som kvinnligt respektive manligt könskodade objekt att arbeta med? Dylika studier skulle med fördel kunna analyseras med hjälp av den matris som utvecklats i den här avhandlingen. 
Kapitel 10: Slutsatser och fortsatt forskning 


\section{Epilog}

Under de senaste tre åren, efter att empirin till denna avhandling insamlades, har svensk djursjukvård och därmed även veterinärsektorn i Sverige genomgått stora förändringar. Fram till 2012 dominerades den svenska djursjukvården av stora och medelstora företag vid sidan av ett fåtal stiftelseägda djursjukhus. Idag, efter några turbulenta år, är situationen delvis en annan. Den alltmer lukrativa djursjukvården har uppmärksammats av riskkapitalister, som tidigare i Sverige främst associerats med vård, skola och omsorg. Det som till en början beskrevs som en ren huggsexa har stabiliserat sig och numera dominerar främst två stora kedjor med inriktning mot djursjukvård i Sverige: AniCura och Evidensia (se bilaga 2). Tillsammans har dessa två företagskedjor knutit till sig ca $60 \%$ av veterinärsektorns företag, uppköpen är dock fortgående.

Enligt Svensk Djursjukvårds branschrapport (2014) omsätter huvudaktörerna AniCura och Evidensia tillsammans uppskattningsvis 1,5 miljarder kronor och har ca 1600 anställda. Jämförelsevis omsätts 3,3 miljarder kronor på hälso-och sjukvård för sällskapsdjur i Sverige. I och med detta kan nära hälften av den totala omsättningen för hälso- och djursjukvård för sällskapsdjur i Sverige i dag kopplas till riskkapital. Många företag har valt att sälja till dessa aktörer men det finns de som öppet deklarerar att de inte är till salu och som även använder detta i sin marknadsföring gentemot djurägare. Oron för vad denna förändring har och ska komma att innebära för veterinärprofessionen, djursjukvården samt djurägarna har ventilerats i dagspress, kvällstidningar, veterinärförbundets egen tidning samt $i$ andra branschsammanhang. Inte minst har en oro för höjda försäkringspremier lyfts fram (Neurath \& Almgren, 2014). Vid sidan av de två "drakarna" finns dock fortfarande ca 400 enskilda djursjukvårdsföretag i Sverige, företag som av olika anledningar inte varit till salu alternativt inte har varit intressanta att köpa upp.

Inträdet av företagskedjorna AniCura och Evidensia har även påverkat den östgötska delen av veterinärsektorn. Sex stycken av de största företagen i länet med inriktning mot djursjukvård har sedan denna studies begynnelse köpts upp. Inget av dessa företag tillhör någon av professionsföretagarna i föreliggande studie. Vidare hör ett nystartat företag i länet till franchisekedjan Vettris (se bilaga 2). 
"There is no real ending. It's just the place where you stop the story"

\author{
Frank Herbert
}




\section{English summary}

\section{Introduction and aim of the study}

In the last decades Sweden has, like many other countries, gone through transformations with the purpose of increasing business ownership in the public sector (Government Bill, 1990/91). The political ambition has been to increase women's small business ownership 45 (Hirdman, 2014; Olofsson, 2010). Both quantitative and qualitative research on the transformations reinforces the conclusion that the gender order is reproduced in business ownership both internationally (Thomas \& Davies, 2002) and in the Swedish context (Sköld, 2015; Sundin \& Tillmar, 2010a).

At the same time structural transformations in society are affecting professions including as medicine, dentistry and teaching through a decrease of the public sector and an increase of the private sector (Svensson, 2003). The medical profession, accounting and teaching are also professions that are characterized by changes in the number of women, both in Sweden (Florin, 1987; Jonnergård \& Stafsudd, 2009; Nordgren, 2000) and internationally (Crompton \& Lyonette, 2011; San Román \& Cortina, 2006). From previous research we know that education is important for women's small business ownership, for example in providing security and legitimacy in dealing with authorities (Holmquist \& Sundin, 2002). At the same time studies show that several of the classic professions, such as medicine and law, are gender coded (Einarsdottir, 1999; Lindgren, 2008).

Research on women's business ownership is more extensive today than 25 years ago. Yet compared to what is produced in the context of small business and entrepreneurship research, research on women's business ownership is still a very small part (Achtenhagen \& Tillmar, 2013; Sundin \& Holmquist, 2015). To understand how and why small business ownership develops as it does over time and how this affects and is affected by the gender order we need more knowledge about women's business ownership within professions undergoing changes. It is at the intersection between the three theoretic fields of small business ownership, profession and gender that this dissertation makes its primary contribution (as illustrated in the figure below).

\footnotetext{
${ }^{45}$ In this English summary I use the term small business ownership to denote what is in Swedish termed "småföretagande". A dilemma with the translation is that in Swedish the word is a verb that is suitable in a process perspective such as this whereas in English the word denotes a noun. The study is focused on the process of operating a business, not on the ownership as such.
} 


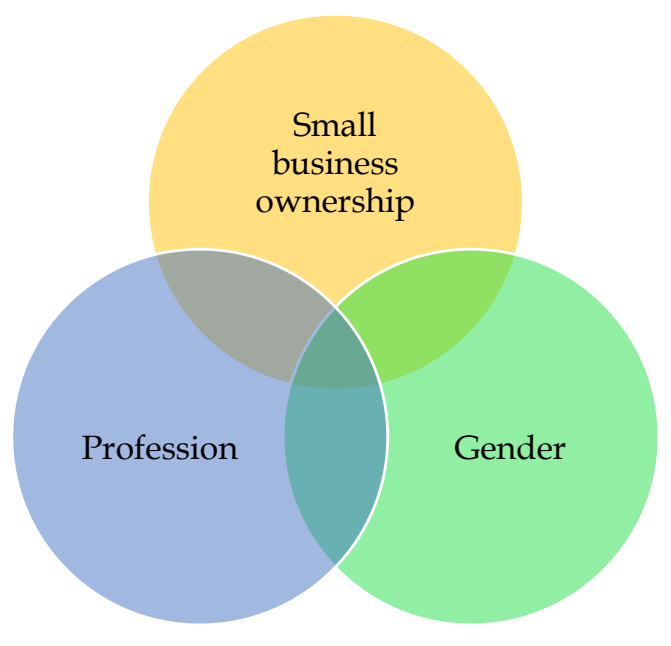

The purpose of the study is to describe and analyze women's business ownership within a profession in a state of change, regarding what happens at the intersection between small business ownership, profession and gender. More specifically it analyzes how gender is done by business owners who are women and members of a profession in a state of change. The research questions of the study are:

How does the interplay between small business ownership and the profession manifest itself?

> How is gender done in relation to being a small business owner and a professional respectively?

$>$ How do changes within the profession and in relation to small business ownership within the profession influence on how gender is done?

In this study the empirical case is the veterinary profession. This profession has been chosen as an interesting case for the study of women's business ownership in a profession in a state of change for two main reasons.

Firstly, the veterinary profession is a clear example of a status profession that has become numerically feminized. The profession's numerical feminization is an international phenomenon (Henry \& Treanor, 2012b; Lofstedt, 2003; Maines, 2007) but is particularly evident in Sweden, where women account for $77 \%$ of the active veterinarians within the profession (Saco, 2014).

Secondly, the veterinary profession is characterized by changes regarding both animal keeping and in the animals that account for the veterinarians' primary work area, as 
well as an increase in business ownership (Appelgren, Jämte, \& Östensson, 2010; SOU, 2007:24).

\section{The veterinary profession in Sweden}

In the last century structural transformations have changed the Swedish society and we have gone from agriculture, fishing and manual labor to an economy which is largely based on services (Schöön, 2014). In connection with these changes, the Swedish agricultural sector has gone from being a primary industry dependent on animal and human muscle power to becoming a high-tech industry with a limited number of employees (Flygare \& Isacson, 2003).

Parallel with this, farm animals of virtually every kind have declined in numbers between 1980 and 2005 (SOU, 2007:24). Meanwhile the number of small/domestic animals has increased. For veterinarians, this has meant a growth in small/domestic animal care and a reduction in large animal work.

The origins of today's Swedish veterinary profession emerged in the late 1700s (Hallgren, 1962) and has since been established, organized and developed continuously. The 1900s were a tumultuous century for the profession, not least because of the transformation of the agricultural sector. At present, veterinary activities in the Swedish market are undertaken both by state "district veterinarians" employed by the Swedish Board of Agriculture and by veterinarians in the private sector (SOU, 2007:24).

The district veterinarian's main task is to provide nationwide emergency veterinary care, to maintain 24-hour preparedness for the control of infectious animal diseases and to conduct preventive animal health care for all animals in human care. The district veterinarians are largely financed by fees and central government grants (Distriktsveterinärerna, 2015; Jordbruksverket, 2015). Over time, state veterinary activities have focused increasingly on animal care for pets and horses alongside farm animals (SOU, 2007:24). This organization, in addition to the veterinary education, has become a "rite of passage" for newly qualified veterinarians (Appelkvist, 2013).

The Swedish veterinary profession is characterized by a numerical feminization (c.f. Saco, 2014). The pioneer Waldy Bergengren was admitted to the veterinary education in 1914 (Hallgren, 1962). However, it was not until 1930 that more women were admitted to veterinary training (Hellberg, 1978). The proportion of female veterinary students increased tenfold between 1955 - 1970, and women constituted more than half of the new students in 1973 (Östensson, 2010). The number of veterinarians working in Sweden in 2014 amounted to 2,365 (of which 77\% were women and 23\% men). 
Women are in the majority in the profession in general, although it is more common that they are private sector employees than business owners (Saco, 2014).

As the veterinary profession, in Sweden and internationally, has become increasingly numerically feminized various explanations have been offered with regard to the cause of the phenomenon. Four explanations are predominant in the Anglo-Saxon research: (1) women gaining the right/access to higher education (Slater \& Slater, 2000); (2) the development of anesthesia and sedatives to facilitate handling of large animals (Slater \& Slater, 2000); (3) the existence of female role models (Smith, 2002); and (4) the media image of the caring veterinarian (Lofstedt, 2003).

\section{Theoretical frame of reference}

The theoretical frame of reference in this dissertation takes its starting point in the three research fields of small business ownership, profession and gender and in particular in the areas in which these fields overlap.

Small business ownership is the focus of this dissertation but since the research on small business ownership and entrepreneurship partially overlap I will also include theories on entrepreneurship ${ }^{46}$ where these can be applied. The principal interest lies in processes rather than qualities.

I use both sex and gender as terms with the distinction that sex is linked to biology (man/woman) while gender refers to what is socially and culturally constructed (male/female). The gender system is a way of describing and highlighting power relations between the sexes on a structural level (Hirdman, 1988). That gender is something which is done is a theoretical point of departure which can be included under the term “doing gender"(West \& Zimmerman, 1987). I see combining a "doing gender" starting point with the gender system's principles of hierarchization and segregation as a fruitful way to study the pendulation between structure and actor. It opens up for the possibility to see both stability and change in terms of gaps in the pattern of the system (jmf Fogelberg Eriksson, 2005).

There are a number of definitions and classifications of what constitutes a profession. The term refers to, among other things, an organization of work according to occupation and encompasses criteria such as knowledge monopoly and autonomy (Molander \& Terum, 2008). In terms of their characteristics, professions are heterogeneous rather than homogeneous.

\footnotetext{
${ }^{46}$ Whether the small business owners studied are entrepreneurial or not (in the Schumpeterian sense) has however not been an issue for the study at hand. Hence, I do not use 'entrepreneurship' as the core concept in this English summary.
} 
Greater attention is being paid to women's business ownership within the research community but in relation to what is written within the framework of research on small business ownership and entrepreneurship it is still only a small part. The focus of this research has shifted from studies of business ownership to studies of discourse in the media and policy documents. Just as Barley and Kunda (2001) advocated a return to studying the tangible organization of work so do I wish in this study to return to studying the everyday situation of the business owner as it is described by business owners themselves.

It has long been observed that business ownership and entrepreneurship are embedded in their context, in a way which has great significance for how the business is conducted. When a profession has control over knowledge and work tasks this creates good conditions for business. Several professions have a tradition of business ownership, yet despite this the research on business and profession in combination is limited. Life mode theory takes as its starting point that people have different ways of managing and living their lives and of making decisions as a result of different conditions. In life mode theory, business ownership has primarily been linked to the life mode of independence and in relation to women's business ownership a number of categories of business ownership have been developed. Life mode theory has also been related to business ownership in rural areas. In rural areas there is a tradition of an independent way of life (Glesbygdsverket, 2008a). This tradition has been underpinned primarily by the agricultural and forestry industries. In this study, the rural area is a spatial context which must be taken into account since 7 of 10 interviewees are located in a rural area.

Several of the traditional professions are characterized by a male gender code. This gender code is also expressed within professions in the form of an internal segregation. The internal segregation can be seen as part of the closure strategies (Witz, 1992) utilized by professions to uphold and maintain knowledge and a professional monopoly against adjoining groups. It is primarily in this way that I will utilize the terminology of closure theory in this dissertation (that is to say within a profession and from a gender perspective).

Research which combines small business ownership, profession and gender is limited. Some studies have focused on the identity of the business owner. Others have discussed how the status of the profession affects the subordination of women. In a Swedish study of married couples who jointly owned businesses Javefors Grauers (2002) found that in the case of the women lawyers the profession contributed to modifying the expression of the gender system. In contrast, Marlow and Carter (2004) argue that the subordination persists even in the context of a profession (in this case in the context of the United Kingdom and the accounting profession). 


\section{Methodology}

In this study women's business ownership is studied as framed within a profession in a state of change. The aim has been to describe and analyze the interplay between business ownership, profession and gender.

Since I knew only little about the organization of the veterinary profession at the beginning of the study my first port of call in the research process was to read up on the subject. This was done primarily during the spring of 2010 but is something to which I have returned on a number of occasions during the course of the study. Information of various types has been retrieved and combined for the purpose of providing a nuanced background to the study, including official documents from the Swedish Board of Agriculture, the Swedish Government and the County Administration of Östergötland, among others. A mapping of all businesses with veterinary activities in Östergötland has constituted another important part of the research process since this was the basis for the selection for interviews. The mapping also aimed to provide an overview of the private veterinary sector in the county.

A qualitative approach and in-depth interviews were considered a relevant strategy to fulfil the aim of the study. The interview study includes all women (ten) who were business owners and veterinarians in Östergötland in 2011. The average age of the interviewees was 51.5, where the youngest was 39 and the oldest 63 .

The interview guide was designed as a list of topics and can be termed semi-structured (Bryman \& Bell, 2005). This implies that the interview process is flexible and allows the interviewees to have a large degree of freedom to express their answers in their own way. Semi-structured or topic-based interviews have the advantage that they make it clear for the interviewee that the basis for the interview is their narrative, rather than specific questions which have been prepared in advance (Thomsson, 2010). In this way this method of interview also laid the foundation for what came to be developed as life stories.

The topics included in the interview guide covered aspects such as the interviewees' background in terms of profession and business ownership, as well as circumstances around the establishment of the business and the present business. The interview guide was used primarily as a checklist at the end of the interview, to ensure that nothing important had been missed. The interviews lasted on average 1.5 hours. The interviews were recorded digitally and I transcribed them myself in full in order to facilitate the subsequent analysis work. The analysis was done in multiple steps through the use of categorization.

\section{Results}

Most interviewees emphasize that small business ownership is all about freedom. A closer examination of this freedom, however, shows that it is in many ways limited. 
The interviewees express various kinds of ambition, linked to their own learning, balance in life, or simply in the effort to address various shortcomings. The ambitions are largely based in the profession, but the outlet for them is often reflected in the business. What they regard as a successful business is related in many cases to their own situation. It becomes clear that the profession is seen as a large part of what constitutes a successful business. At the same time the interviewees describe a balancing act in terms of business and profession, in which one is sometimes given priority over the other. But there are also situations where business and profession interact and where the quest for the one is made possible by the other.

The interviewees have a varying degree of previous experience of business ownership. Some have grown up with parents who were small business owners. Others have owned a company previously, while some are completely new to the field. In reflections on their experiences, business ownership is expressed as demanding. For many of the interviewees starting a business has been a solution. It has been a way to escape a discriminatory workplace or simply a way to earn a living. In their descriptions, business ownership is one piece in the puzzle of life. Adjustments are made to the family situation and vice versa. The profession is a large part of the business ownership. Several of the interviewees express doubts about their own status as business owners.

The image of the veterinary profession and veterinarians painted by the interviewees is full of contrasts. There is a general concern about the future of the profession. While they talk about their own experiences of being treated differently as women in a previously male-dominated profession, they promote male qualities in front of female. Two venues for gender coding are found in animal species and in activities. Working with horses and surgery has an elevated position and has a male gender label. Working with cats and medical investigations has a female label.

\section{I nterpretations and conclusions}

As a result of the study I coin the term "profeneur" to denote the category of business owning professionals with the intention of making visible the interplay between profession and business ownership. This is because the results of the study show that the profession is in many cases given priority over business ownership. Since what is specific to the profession has proven to be prominent in the way in which the business owners talk about their business ownership, I believe that business owning professionals should be viewed as a distinct category of business owners. It is the freedom of owning a business in relation to the profession which is highlighted in the analysis of the profeneurs. For several of the profeneurs, the business has been a solution to problems and barriers that relate to them being women and employed in gendered organizations. Business ownership has been a strategy for practicing their profession more independently. 
Introducing life mode theory into the analysis of profeneurs makes business ownership or self-employment as a way of life visible. Viewing business ownership as an expression of an independent life mode emphasizes that there is an alternative to the perspective held in micro economics of a fully economically rational human being. This study shows that the driving force and the basis of business ownership takes it's starting point in the striving for the independent exercising of profession. Here there is a discrepancy in relation to the life mode theory's view of business ownership as a way of life. For the profeneurs, business ownership offers a way to exercise the profession on their own terms. Still, the profession rather than the business ownership is their way of life. I consider business owning professional as an appropriate term to include in the life mode theory.

Gender is done on a general level by the profeneurs when they discuss women as a group based on traditional perceptions of sex in situations where the man is the norm. This is true in relation to both profession and business ownership. That which is considered masculine is elevated as a norm by the profeneurs at the same time as that which is considered feminine is rejected as deviating and unprofessional.

Given that the veterinary profession has undergone such a pronounced numerical feminization this can be regarded as both remarkable and particularly interesting. It is in line with research which shows that numerically feminized professions continue to be characterized by masculine norms (Irvine \& Vermilya, 2010) and that the disadvantage of being a woman and a business owner still exists to some extent in the context of a profession (Marlow \& Carter, 2004). The result is also a contribution to the continuing discussion as to whether the feminization of professions has a positive impact on the gender system (Bottero, 1992; Davies, 1996) or simply implies that exclusion is exchanged for inclusion, in the form of internal segregation and exploitation within the profession (Bolton \& Muzio, 2007; Walby, 1986). The strength in the gender code of a profession is here made visible, as with the gender code of business ownerships.

At the same time this study shows that gender is also done at a specific level in that the profeneurs emphasize their businesses and revalue themselves and their feminine coded skills based on alternative views of traditional and normative perceptions in both business ownership and profession. To take an example, qualities such as flexibility and consideration are held up as advantages in the competition for customers. These are aspects of the exercising of profession which are perceived as central by the business owning professionals, but which would not have been possible if acting as an employee in an organization characterized by male gender codes. In this way the traditional gender codes of both business ownership and profession are challenged in the daily activities of the profeneurs.

Gender is done primarily in relation to profession. I interpret this as being a consequence of the profession serving as the main basis for the profeneurs. The study further shows that gender is also done in different dimensions within the profession. 
Internal segregation within a profession is a phenomenon which has previously been pointed out by Einarsdottir (1997) as well as Bolton and Muzio (2007). In this study I have gone one step further and show that doing gender creates internal segregation in both the subject/object and work tasks dimensions. These dimensions are part of the overall pattern of how gender is done and through them the gender system is both confirmed and challenged.

With regards to subject/object the study shows that some of these aspects are gender coded as male while others are gender coded as female. The subject in these cases might be different categories of patients. In the veterinary profession this is something which has also had consequences in the education system, in the form of an attempt to impose admission quotas for men after the decision makers expressed a fear that without these there would be a shortage of practitioners specializing in certain male gender coded subjects/objects. With regards to work tasks, surgery is given a male gender code and thereby elevated status in contrast to the female gender coded work of medical investigations. At the same time the profeneurs tone down the importance of surgery at the specific level. Here there is a stronger emphasis on variation and challenges but also on ethics and on quality as being more valuable.

How gender is done among the profeneurs at different levels is illustrated in the figure below:

\section{Dimension}

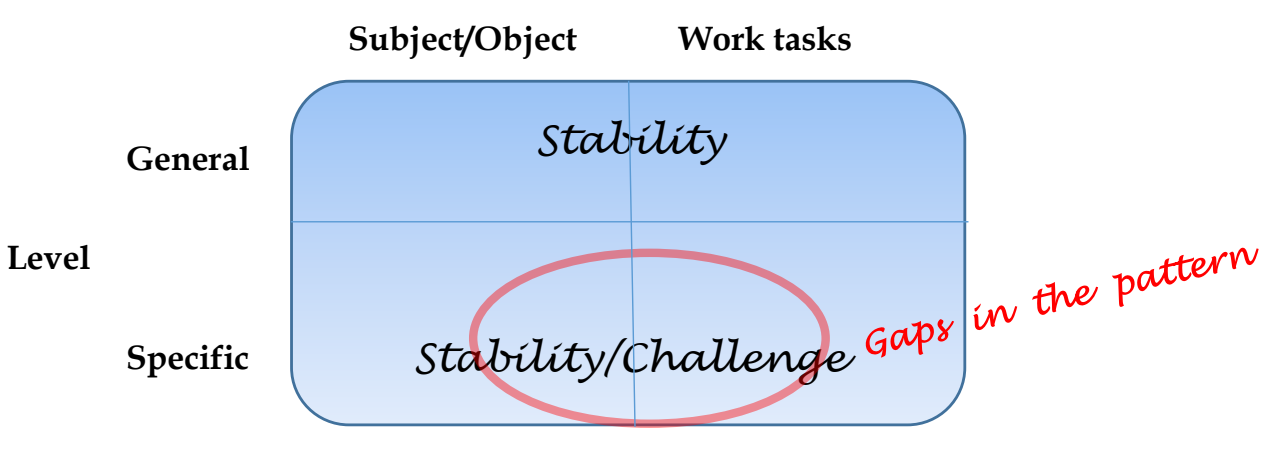

Even though the profeneurs primarily do gender in relation to profession, it is also apparent that they do gender in relation to business ownership - explicitly as well as implicitly. The phenomenon of business ownership is described as being extremely demanding and in relation to this male business owners are held up as good examples as, for example, being visionary and having the driving forces for action. The prevailing gender pattern is thus reproduced when men's business ownership is elevated as a norm in comparison to women's business ownership. Male business owners are frequently presented as good role models as opposed to women business 
owners who are presented as deviating from the norm. The profeneurs describe themselves and women in general in terms of uncertainty, caution, and in some cases as untypical. This is done at the same time as they themselves and in the capacity of being small business owners, in several cases with many years of experience, can be seen as both good role models and successful business owners. The pattern of dimensions and levels is not as obvious in relation to business ownership as it is in relation to profession.

Changes in the form of a numerical feminization have not had any significant impact on how gender is done in relation to the profession in question. Despite the increasing number of women in the profession male gender coded norms are sustained. The result of the study thus supports the research showing that an organization or profession which is numerically dominated by women is not necessarily characterized by a corresponding feminine culture (Acker, 1990; Britton, 2000; Irvine \& Vermilya, 2010). As is described above, this applies particularly on a general level.

On a specific level, in contrast, it is clear that the changes do not pass unnoticed. Conducting their profession in the business format allows women who are members of a profession to have certain autonomy in the exercise of their profession, as well as a distance to the masculine norms within the profession which have been dominant in previous workplaces. Business ownership has thus impacted the doing of gender by making it possible for the profeneurs to exercise their profession more independently and to observe (and talk about) the profession in a way which challenges the traditional masculine gender coded norms. This creates certain gaps in the gender system's otherwise so consistent pattern.

The profeneurs interviewed revalue professional capabilities such as consideration and flexibility, as well as female gender coded subjects/objects and work tasks. Further, several of the profeneurs can perform male gender coded work tasks but also more generally dedicate themselves to a type of activity within the framework for their business ownership which they were unable to do as employees. Put differently, the study shows that business ownership is a condition for the discrepancy between the levels described above. At the particular point in time at which the study was made, in the particular place where it was conducted, there was scope for a certain freedom of action for business ownership among professionals.

This line of reasoning illustrates that gender is done both in relation to the traditional circumstances within the profession and to business ownership as well as in relation to the current changes (numerical feminization, changed animal keeping and increased business ownership). The old meets the new in the constant doing of gender, profession and business ownership. The changes provide conditions for creating gaps in the gender system's pattern, which in turn influences both the profession and the business ownership. 


\section{Suggestions for further research}

There is still much to be done with regards to studies of women's business ownership. Studies which make nuances visible and take account of a diversity of contexts are of great importance for showing both the possibilities and the limitations for women's business ownership. Conditions and circumstances are to some extent reproduced, as we have seen, in the business ownership. To understand this, further studies of stability and change with regards to the gender system are required. Studies of both rural and urban contexts but also in relation to other professions are necessary to create a richer picture of the processes which take place at the intersection between small business ownership, gender and profession. 


\section{Referenser}

Abbott, A. (1988). The System of Professions - An Essay on the Division of Expert Labor. Chicago: The University of Chicago Press.

Abrahamsson, B. (1986). Vad är Intressant med Professioner. In D. Broady (Ed.), Professionaliseringsfällan. Borås: Carlssons.

Abrahamsson, L. (2004). Organisationsförändringar och det Könssegregerande Arbetslivet. In SOU 2004:43 (Ed.), Den Könsuppdelade Arbetsmarknaden.

Achtenhagen, L., \& Tillmar, M. (2013). Editorial: Studies on Women's Entrepreneurship from Nordic Countries and Beyond. International Journal of Gender and Entrepreneurship, 5(1).

Acker, J. (1990). Hierarchies, Jobs, Bodies: A Theory of Gendered Organizations. Gender and Society, 4(2), 139-158.

Acs, Z. (2006). How is entrepreneurship good for economic growth? Innovations, 1(1), 97-107.

Agevall, L., \& Jonnergård, K. (2010). Vad är Professioner? In T. Klasson (Ed.), Professioner i Offentlig Förvaltning. Lund: Studentlitteratur.

Agria Djurförsäkring. (2012). Fakta om antal sällskapsdjur i Sverige 2012. Retrieved 2015-11-26, from http://www.agria.se/pressrum/pressmeddelanden-2013/scb-studie-2012-av-antaletsallskapsdjur/

Agria Djurförsäkring. (2013). Katten är det vanligaste sällskapsdjuret. Retrieved 2015-11-26, from http://www.agria.se/pressrum/pressmeddelanden-2013/katten-ar-det-vanligastesallskapsdjuret/

Ahl, H. (2004). The Scientific Reproduction of Gender Inequality. Malmö: Liber AB.

Ahl, H. (2006). Why research on women entrepreneurs needs new directions. Entrepreneurship: Theory and Practice, 30(5), 595-621.

Ahl, H., Berglund, K., Pettersson, K., \& Tillmar, M. (2016). From feminism to FemInc. ism: On the uneasy relationship between feminism, entrepreneurship and the Nordic welfare state. International Entrepreneurship and Management Journal, 12(2), 369-392.

Alsos, G., Jensen, R., \& Ljunggren, E. (2010). Gender and entrepreneurship: revealing constructions and underlying processes-the case of Norway. In C. Brush, A. de Bruin, E. J. Gatewood, \& C. Henry (Eds.), Women Entrepreneurs and the Global Environment for Growth: A Research Perspective (pp. 40-56). Cheltenham: Edward Elgar Publishing.

Alvesson, M., \& Sköldberg, K. (2008). Tolkning och Reflektion - Vetenskapsfilosofi och Kvalitativ Metod (2 ed.). Lund: Studentlitteratur.

Andersen, H. (1994). Vetenskapsteori och Metodlära - En Introduktion. Lund: Studentlitteratur.

AniCura. (2015). Om AniCura. Retrieved 2015-04-13, from http://www.anicuragroup.com/

Ansvarsnämnden för djurens hälso- och sjukvård. (2015). Om nämnden. Retrieved 2015-04-09, from http://www.vetansvar.se/introsida/startsida/omnamnden.4.778a5d1001f29869a7fff2220.ht $\mathrm{ml}$

Appelgren, L.-E., Jämte, I., \& Östensson, K. (2010). Veterinär - Yrke i Förvandling. Från manligt till kvinnligt, från ensamvarg till lagarbetare: Sveriges Veterinärförbund 150 år Jubileumsutgåva.

Appelkvist, J. (2013). Det Självklara Företagandet? Kvinnors företagande i veterinärprofessionen. (Licentiatavhandling), Linköpings universitet, Linköping.

Ashcraft, K. L., Muhr, S. L., Rennstam, J., \& Sullivan, K. (2012). Professionalization as a Branding Activity: Occupational Identity and the Dialectic of Inclusivity-Exclusivity. Gender, Work and Organization, 19(5), 467-488. 
AVMA. (2012). Market Research Statistics - U.S Veterinarians. Retrieved 2013-04-09, from https://www.avma.org/KB/Resources/Statistics/Pages/Market-research-statistics-USveterinarians.aspx?PF $=1$

Barley, S. R., \& Kunda, G. (2001). Bringing work back in. Organization Science, 12(1), 76-95.

Berglund, K. (2007). Jakten på entreprenörer: om öppningar och låsningar i entreprenörskapsdiskursen. Mälardalen University, Västerås.

Berglund, K., \& Johansson, A. W. (2007). Contructions of Entrepreneurship: A Discourse Analysis of Academic Publications. Journal of Enterprising Communities: People and Places in the Global Economy, 1(1), 77-102.

Bergqvist, T. (2004). Självständighetens livsform(er) och småföretagande - tillämpning och utveckling av realistisk livsformsanalys. (Doktorsavhandling), Karlstads universitet, Karlstad.

Bird, S. R., \& Rhoton, L. A. (2011). Women Professionals' Gender Strategies: Negotiating Gendered Organizational Barriers. In E. L. Jeanes, D. Knights, \& P. Yancey Martin (Eds.), Handbook of Gender, Work \& Organization. Wiltshire: Wiley.

Bjerke, L., Johansson, S., \& Pettersson, L. (2012) Arbete och liv på landsbygden - Landsbygdens förutsättningar i kunskapsekonomin. 2012:19 Jordbruksverket:

Blackburn, R., \& Kovalainen, A. (2009). Researching Small Firms and Entrepreneurship: Past, Present and Future. International Journal of Management Reviews, 11(2), 127-148.

Bolton, J. E. (1971). Small Firms: Report of the committee of Inquiry on Small Firms. London: Her Majesty's Stationery Office.

Bolton, S., \& Muzio, D. (2008). The Paradoxical Processes of Feminization in the Professions: The Case of Established, Aspiring and Semi-professions. Work, Employment \& Society, 22(2), 281-299.

Bolton, S. C., \& Muzio, D. (2007). Can't Live with'Em; Can't Live without'Em Gendered Segmentation in the Legal Profession. Sociology, 41(1), 47-64.

Booth, A. L., Francesconi, M., \& Frank, J. (2003). A Sticky Floors Model of Promotion, Pay and Gender. European Economic Review, 47(2), 295-322.

Bottero, W. (1992). The Changing Face of the Professions - Gender and Explanations of Womens Entry to Pharmacy. Work, Employment and Society, 6(3), 329-346.

Bradley, H. (1989). Men's Work, Women's Work - A Sociological History of the Sexual Division of Labour in Employment. Cambridge: Polity Press.

Bradley, H. (2013). Gender. Cambridge: Polity.

Braunerhjelm, P. (2007). Behövs entreprenörerna? Om deras betydelse för kunskapsutveckling, kommersialisering och tillväxt. Ekonomisk debatt, 35(6).

Bridge, S., \& O'Neill, K. (2012). Understanding enterprise: entrepreneurship and small business: Palgrave Macmillan.

Britton, D. (2000). The Epistemology of the Gendered Organization. Gender \& Society, 14, 418-434.

Brock, D. M. (2006). The changing professional organization: A review of competing archetypes. International Journal of Management Reviews, 8(3), 157-174.

Bruni, A., Gherardi, S., \& Poggio, B. (2004). Entrepreneur-mentality, Gender and the Study of Women Entrepreneurs. Journal of Organizational Change Management, 17(3), 256-268.

Brush, C. G., Carter, C., Gatewood, E. J., Greene, P. G., \& Hart, M. (Eds.). (2006). Growth-oriented women entrepreneurs and their businesses: A global research perspective. Cheltenham: Edward Elgar Publishing.

Brush, C. G., De Bruin, A., Gatewood, E. J., \& Henry, C. (2010). Women entrepreneurs and the global environment for growth: a research perspective. Cheltenham: Edward Elgar Publishing.

Brush, C. G., De Bruin, A., \& Welter, F. (2009). A Gender-aware Framework for Women's Entrepreneurship. International Journal of Gender and Entrepreneurship, 1(1), 8-24.

Bryman, A., \& Bell, E. (2005). Företagsekonomiska Forskningsmetoder. Malmö: Liber.

Bögenhold, D. (2004). Creative Destruction and Human Resources. Small Business Economics, 22, 165-177.

Bögenhold, D., \& Fachinger, U. (2013). Rationality of Self-employment: Do Female and Male Entrepreneurs Differ? Journal of Business and Finance, 1(2), 21. 
Bögenhold, D., Heinonen, J., \& Akola, E. (2014). Entrepreneurship and Independent Professionals: Social and Economic Logics. International Advances in Economic Research, 20(3), 295-310.

Chef Distriktsveterinärernas huvudkontor (2010-04-14). Personlig kommunikation.

Christensen, L. R. (1987). Hver vore veje. Livsformer, familietyper og kvindeliv. Lyngby: Etnologisk Forum.

Collins, P. H., Maldonado, L. A., Takagi, D. Y., Thorne, B., Weber, L., \& Winant, H. (1995). Symposium On West and Fenstermaker's "Doing Difference". Gender and Society, 9(4), 491-506.

Colyar, J. (2009). Becoming Writing, Becoming Writers. Qualitative Inquiry, 15(2), 421-436.

Crompton, R., \& Lyonette, C. (2011). Women's Career Success and Work-life Adaptations in the Accountancy and Medical Professions in Britain. Gender Work and Organization, 18(2), 231254.

Cron, W. L., Bruton, G. D., \& Slocum Jr., J. W. (2006). Professional Service Ventures, Performance and the Gender Effect. Journal of Leadership and Organizational Studies, 12(3), 53-67.

Dahlman, C. (2004) Kvinnors företagande. Svenskt Näringsliv

Dambrin, C., \& Lambert, C. (2008). Mothering or auditing? the case of two Big Four in France. Accounting, Auditing and Accountability Journal, 21(4), 474-506.

Daunfeldt, S.-O., \& Halvarsson, D. (2011) Snabbväxarnas dynamik - Är hög företagstillväxt uthållig? Rapport 2011:27 Östersund: Tillväxtanalys

Davies, C. (1996). The Sociology of Professions and the Profession of Gender. Sociology, 30(4), 661678.

de Bruin, A., Brush, C. G., \& Welter, F. (2006). Introduction to the Special Issue: Towards Building Cumulative Knowledge on Women's Entrepreneurship. Entrepreneurship Theory and Practice(September), 585-593.

Dellgran, P., \& Höjer, S. (2005). Rörelser i tiden. Professionalisering och privatisering i socialt arbete. Socialvetenskaplig tidskrift, 2-3, 246-267.

Deutsch, F. M. (2007). Undoing Gender. Gender \& Society, 21(1), 106-127.

Diaz-Garcia, C., Brush, C., Gatewood, E., \& Welter, F. (Eds.). (Kommande). Women's Entrepreneurship in Global and Local Contexts. Cheltenham: Edward Elgar Publishing.

Distriktsveterinärerna. (2015). Om Distriktsveterinärerna. Retrieved 2015-01-14, from http://www.distriktsveterinarerna.se/

Drum, S., \& Whiteley, H. E. (1991). Women in veterinary medicine: profiles of success. Ames lowa state university press.

Due Billing, Y., \& Alvesson, M. (1989). Four Ways of Looking at Women and Leadership. Scandinavian Journal of Management, 5(1), 63-80.

Einarsdottir, G. (1999). The Gendering of Status and Status of Gendering - The Case of the Swedish Medical Profession. In I. Hellberg, M. Saks, \& C. Benoit (Eds.), Professional Identities in Transition - Cross Cultural Dimensions. Södertälje: Almqvist \& Wiksell International.

Einarsdóttir, T. (1997). Läkaryrket i förändring : en studie av den medicinska professionens heterogenisering och könsdifferentiering. Göteborg.

Ekstedt, E., \& Sundin, E. (2006). Den Nya Arbetsdelningen - Dimensioner och Perspektiv. In E. Ekstedt \& E. Sundin (Eds.), Den Nya Arbetsdelningen - Arbets- och Näringslivets Organisatoriska Omvandling i Tid, Rum och Tal (Vol. 2006:11). Stockholm: Arbetslivsinstitutet.

Eriksson, K., \& Eriksson, M. (2002). " Kön har ingen betydelse men könsblandning är bra":" könsgörande" i två professionella sammanhang. Tidskrift för genusvetenskap(1), sid 53-72.

Evidensia. (2015). Retrieved 2015-04-13, from http://www.evidensia.se/

Felsted, K. E. (2000). Why do Women Earn Less? Veterinary Economics(October), 33-38.

Florin, C. (1987). Kampen om Katedern - Feminiserings och Professionaliseringsprocesser Inom den Svenska Folkskolans Lärarkår 1860-1906. (Doktorsavhandling), Umeå Universitet, Umeå.

Flygare, I. A. (1999). Generation och kontinuitet - Familjejordbruk i två svenska slättbygder under 1900-talet. (Doktorsavhandling), Sveriges Lantbruksuniversitet, Helsingborg.

Flygare, I. A., \& Isacson, M. (2003). Jordbruket i välfärdssamhället 1945-2000. Örebro: Natur och Kultur/LTs förlag. 
Fogelberg Eriksson, A. (2004). Glipor i mönstret - att lära sig genus på jobbet. In P.-E. Ellström \& G. Hultman (Eds.), Lärande och förändring i organisationer - om pedagogik i arbetslivet. Lund: Studentlitteratur.

Fogelberg Eriksson, A. (2005). Ledarskap och Kön. En Studie av Ledare och Maskuliniteter i ett Verkstadsindustriföretag. (Doktorsavhandling), Linköping universitet, Linköping.

Forsberg, L. (2012). Manegen är Krattad - Om Flickors och Kvinnors Företagsamhet i Hästrelaterade Verksamheter. (Doktorsvhandling), Luleå tekniska universitet, Luleå.

Freidson, E. (2001). Professionalism, the Third Logic: On the Practice of Knowledge. Chicago: The University of Chicago Press.

Företagarna. (2013) Perspektiv på landsbygdsföretagande - landsbygdsföretagarnas villkor och verklighet.

Gandemo, B. (1996). Tillväxt och Förändring. In B. Johannisson \& L. Lindmark (Eds.), Företag, Företagare, Företagsamhet. Lund: Studentlitteratur.

Gartner, W. B. (1989). "Who is an Entrepreneur?" Is the Wrong Question. Entrepreneurship Theory and Practice, Summer, 47-68.

Gatewood, E. J., Brush, C. G., Carter, N. M., Greene, P. G., \& Hart, M. M. (2009). Diana: A symbol of women entrepreneurs' hunt for knowledge, money, and the rewards of entrepreneurship. Small Business Economics, 32(2), 129-144.

Gatewood, E. J., Carter, N. M., Brush, C., Greene, P. G., \& Hart, M. (2003). Women entrepreneurs, their ventures and the venture capital industry: An annotated bibliography. Stockholm: ESBRI.

Giddens, A. (1984). The constitution of society: Outline of the theory of structures. Oakland: CA: University of California Press.

Glesbygdsverket. (2008a) Kvinnors företagande i gles- och landsbygder - Fakta och fönster.

Glesbygdsverket. (2008b) Landsbygdsdefinitioner i Sverige och andra länder.

Goffee, R., \& Scase, R. (1985). Women in Charge. London: Allen \& Unwin.

Government Bill. (1990/91) Utveckling av Offentlig Sektor - Gemensamma Frågor. 1990/91:100 Civildepartementet

Granovetter, M. (1985). Economic Action and Social Structure: The Problem of Embeddedness. American Journal of Sociology, 91, 481-510.

Greiff, M. (2006). Kall eller profession? : yrkeskulturer och skapandet av manligt och kvinnligt mellan klient och arbetsköpare. In H. Petersson, V. Leppänen, S. Jönsson, \& J. Tranquist (Eds.), Villkor $i$ arbete med människor : en antologi om human servicearbete 2006 (pp. 111-136). Stockholm: Arbetslivsinstitutet 2006:4.

Gunnarsson, E., Andersson, S., Vänje Rosell, A., Lethto, A., \& Salminen-Karlsson, M. (2003). Where have all the structures gone? Doing gender in organisations, Examples from Finland, Norway and Sweden. Stockholm: Stockholms universitet, Center for women's studies.

Gustavsson, M., \& Rönnqvist, D. (2004). Företagare i sin profession : i spänningsfältet mellan företagar- och yrkesidentitet. Stockholm: Verket för näringslivsutveckling (NUTEK).

Göteborgs-posten. (1995-06-20). Veterinärförhandling strandad, p. 30.

Göteborgs-posten. (1995-06-23). Ny organisation för veterinärer, p. 23.

Hallgren, W. (1962). Svensk Veterinärhistoria i Ord och Bild: Allhems Förlag.

Hamilton, E. (2013). The discourse of entrepreneurial masculinities (and femininities). Entrepreneurship and Regional Development, 25(1-2), 90-99.

Hammarberg, K. (2010). Från kon i båset till hunden i sängen. In L.-E. Appelgren, I. Jämte, \& K. Östensson (Eds.), Veterinär - yrke i omvandling: Sveriges veterinärförbund 150 år Jubileumsutgåva.

Hamrud, A. (2009, 2009-03-31). Universitetet fälls för könsdiskriminering. Dagens Nyheter, p. 11.

Harding, S. (1987). Introduction: Is There a Feminist Method? In S. Harding (Ed.), Feminism \& Methodology. Bloomington, Indiana: Indiana University Press.

Hasselbladh, H., \& Bejerot, E. (2008). New Public Management - En Problematisering i Tiden. In H. Hasselbladh, E. Bejerot, \& R. Å. Gustafsson (Eds.), Bortom New Public Management. Göteborg: Göteborgs Universitet. 
Hellberg, I. (1978). Studier i Professionell Organisation. En Professionsteori Tillämpad på Veterinäryrket. (Doktorsavhandling), Göterborg universitet, Göteborg.

Hellberg, I. (1989). Könsutjämning och Könspolarisering inom Professionerna på Dagens Svenska Arbetsmarknad. In S. Selander (Ed.), Kampen om Yrkesutövning, Status och Kunskap. Lund: Studentlitteratur.

Hellberg, I. (1990). Kvinnligt företagande som sysselsättning, försörjning och livsform - ett exempel. In M. Bäck-Wiklund \& H. Lindfors (Eds.), Arbetets organisering, människans försörjning Vänbok till Bengt G Rundblad. Göteborg: Länsstyrelsens tryckeri.

Hellberg, I. (1999). Altruism and Utility: Two Logics of Professional Action. In I. Hellberg, M. Saks, \& C. Benoit (Eds.), Professional Identities in Transition: Cross-Cultural Dimensions. Södertälje: Almqvist \& Wiksell.

Helsingborgs Dagblad. (1995a, 1995-07-06). Bra system för föräldrar.

Helsingborgs Dagblad. (1995b, 1995-07-06). Veterinärer säger upp sig - missnöjda med den nya statliga organisationen.

Helsingborgs Dagblad. (1995-07-01). Sveriges veterinärer rasar - Jordbruksverkets nya regler beskrivs som "ett kaos".

Helsingfors universitetsmuseum. (2011). Retrieved 2011-05-11, from http://www.museo.helsinki.fi/svenska/utstallningar/kvinnor_vid_universitetet/sjoberg_sve/s joberg2_sve.htm

Henry, C., Baillie, S., \& Treanor, L. (2010). Encouraging Women's Entrepreneurship in the Sciences: Women in Veterinary Medicine. In P. Wynarczyk \& S. Marlow (Eds.), Innovating Women: Contributions to Technological Advancement (Contemporary Issues in Entrepreneurship Research, Volume 1): Emerald Group Publishing Limited.

Henry, C., Foss, L., \& Ahl, H. (2016). Gender and entrepreneurship research: A review of methodological approaches. International Small Business Journal, 34(3), 217-241.

Henry, C., \& Treanor, L. (2010). Entrepreneurship education and veterinary medicine: enhancing employable skills. Education + Training, 52(8/9), 607-623.

Henry, C., \& Treanor, L. (2012a). Exploring entrepreneurship education within veterinary medicine: can it be taught? Journal of Small Business and Enterprise Development, 19(3), 484-499.

Henry, C., \& Treanor, L. (2012b). The Veterinary Business Landscape: Contemporary Issues and Emerging Trends. In C. C. Perez-Marin (Ed.), A Bird's-Eye View of Veterinary Medicine: InTech.

Hirdman, Y. (1988). Genussystemet - Reflexioner Kring Kvinnors Sociala Underordning. Kvinnovetenskaplig Tidskrift(3), 49-63.

Hirdman, Y. (2001). Genus - Om det Stabilas Föränderliga Former. Malmö: Liber.

Hirdman, Y. (2014). Vad bör göras? Jämställdhet och politik under femtio år. Stockholm: Ordfront.

Hjorth, D., \& Steyaert, C. (2004). Narrative and discursive approaches in entrepreneurship: a second movements in entrepreneurship Cheltenham: Edward Elgar.

Holmquist, C. (2008). Fältet Genus och Företagande - Introduktion och Sammanfattning. In P. Larsson, U. Göransson, \& M. Lagerholm (Eds.), Sesam Öppna Dig - Forskarperspektiv på Kvinnors Företagande: Vinnovarapport 2008:20.

Holmquist, C., \& Carter, S. (2009). The Diana Project: Pioneering women studying pioneering women. Small Business Economics, 32(2), 121-128.

Holmquist, C., \& Sundin, E. (Eds.). (2002). Företagerskan - Om Kvinnor och Entreprenörskap. Stockholm: SNS Förlag.

Hood, C. (1995). The "New Public Management" in the 1980s: variations on a theme. Accounting, Organizations and Society, 20(2), 93-109.

Hughes, E. C. (1984). The Sociological Eye: Selected Papers. New Brunswick: Transaction Books.

Hughes, K. D., Jennings, J. E., Brush, C., Carter, S., \& Welter, F. (2012). Extending Women's Entrepreneurship Research in New Directions. Entrepreneurship Theory and Practice, 36(3), 429-442.

Hytti, U. (2003). Stories of entrepreneurs: Narrative construction of identities. (Doktorsavhandling), Turku School of Economics and Business Administration. 
Hytti, U. (2005). New meanings for entrepreneurs: from risk-taking heroes to safe-seeking professionals. Journal of Organizational Change Management, 18(6), 594-611.

Högskoleverket. (2005) Dold könsdiskriminering på akademiska arenor - osynligt, synligt, subtilt.

Höjrup, T. (1983/89). Det Glemte Folk: Livsformer og centraldirigering. Köpenhamn: Institutet för Europaeisk folkelivsforskning och statens byggeforskningsinstitut.

Irvine, L., \& Vermilya, J. R. (2010). Gender Work in a Feminized Profession The Case of Veterinary Medicine. Gender \& Society, 24(1), 56-82.

Isacson, M. (2008). Historien om livet på landet - från mångsyssleri till mångsyssleri. In B. Johansson (Ed.), Ska hela Sverige leva? Stockholm: Formas Fokuserar.

Jack, S. L., \& Anderson, A. R. (2002). The Effects of Embeddedness on the Entrepreneurial Process. Journal of Business Venturing, 17, 467-487.

Javefors Grauers, E. (2002). Profession, Genus och Företagarpar - En Studie av Advokater och Köpmän. (Doktorsavhandling), Linköping universitet, Linköping.

Javefors Grauers, E. (2003) Kvinnor och män som jordbrukare: Lantbruksbaserat företagande och olika stödformer för utveckling av landsbygden i ett genusperspektiv med exempel från Östergötland. R 2003:3 Stockholm Nutek

Johannisson, B. (2008). "Glokalt" företagande till nytta för landsbygden. In B. Johansson (Ed.), Ska hela Sverige leva? Stockholm: Formas Fokuserar.

Johannisson, B., \& Lindmark, L. (1996a). Det Mångfasetterade Småföretagandet. In B. Johannisson \& L. Lindmark (Eds.), Företag, Företagare, Företagsamhet. Lund: Studentlitteratur.

Johannisson, B., \& Lindmark, L. (1996b). Företag , Företagare, Företagsamhet. Lund: Studentlitteratur.

Johansson, A. (2012). Narrativ teori och metod - med livsberättelsen i fokus. Lund: Studentlitteratur.

Johansson, S. (1997). Hälsoprofessioner i Välfärdsstatens Omvandling. In E. Sundin (Ed.), Om Makt och Kön - I Spåren av Offentliga Organisationers Omvandling: SOU 1997:83.

Jonnergård, K., Funck, E. K., \& Wolmesjö, M. (2008). Professionell autonomi som risk och möjlighet. In K. Jonnergård, E. K. Funck, \& M. Wolmesjö (Eds.), När den professionella autonomin blir ett problem. Växjö: Växjö University Press.

Jonnergård, K., \& Stafsudd, A. (2009). Uttalanden om Genusskillnader - Om Kvinnligt och Manligt i Revisionsbranschen. In C. Angelfors \& E. Schömer (Eds.), En Bok om Genus - Nyfikenhet, Nytänkande, Nytta. Göteborg: Växjö University Press.

Jordbruksverket. (2012) Hästhållning i Sverige 2010. Rapport 2012:1

Jordbruksverket. (2014) Årsredovisning

Jordbruksverket. (2015). Arbete inom djurens hälso-och sjukvård. Retrieved 2015-04-08, from http://www.jordbruksverket.se/amnesomraden/djur/djurhalsopersonal/arbeteinomdjurens halsoochsjukvard.4.5586fdf512e8fc79a8480002176.html

Justesen, L., \& Mik-Meyer, N. (2011). Kvalitativa metoder - Från vetenskapsteori till praktik. Lund: Studentlitteratur $\mathrm{AB}$.

Jällhage, L. (2008, 2008-05-10). Chanslös bli veterinär för att hon var kvinna. Dagens Nyheter, p. 9.

Jönsson, G. (2010). Veterinäryrkets Utveckling - En Klassresa i Ord och Bild. In L.-E. Appelgren, I. Jämte, \& K. Östensson (Eds.), Veterinär - Yrke i Förvandling: Sveriges Veterinärförbund 150 år Jubileumsutgåva.

Kay, F., \& Gorman, E. (2008). Women in the legal profession. Annual Review of law and social science, 4, 299-332.

Kelan, E. K., \& Nentwich, J. C. (2009). The value of seeing gender as a 'doing'. In M. F. Özbilgin (Ed.), Equality, diversity and inclusion at work: A research companion. Cheltenham: Edward Elgar.

Kelleher, F. (2011). Women and the teaching profession: exploring the feminisation debate. London: Commonwealth Secretariat.

Korsgaard, S., Ferguson, R., \& Gaddefors, J. (2015). The best of both worlds: how rural entrepreneurs use placial embeddedness and strategic networks to create opportunities. Entrepreneurship \& Regional Development, 27(9-10), 574-598. 
Korvajärvi, P. (1998). Gendering dynamics in white-collar work organizations. (Doktorsavhandling), Acta Universitatis Tamperensis 600, University of Tampere.

Korvajärvi, P. (2003). Doing gender - theoretical and methodological considerations. In E. Gunnarsson, S. Andersson, A. Vänje Rosell, A. Lehto, \& M. Salminen-Karlsson (Eds.), Where have all the structures gone. Stockholm: Center for women's studies.

Kovalainen, A., \& Arenius, P. (2006). Women's entrepreneurship in Finland. In C. Brush, N. Carter, E. Gatewood, P. Greene, \& M. Hart (Eds.), Growth-oriented Women Entrepreneurs and their Businesses. A Global Perspective (pp. 112-127). Cheltenham: Edward Elgar Publishing.

Kovalainen, A., \& Österberg-Högstedt, J. (2013). Entrepreneurship within social and health care: A question of identity, gender and professionalism. International Journal of Gender and Entrepreneurship, 5(1), 17-35.

Kreckel, R. (1980). Unequal Opportunities Structure and Labour Market Segmentation. Sociology, 4, 525-550.

Kvale, S., \& Brinkmann, S. (2014). Den kvalitativa forskningsintervjun (3:rd ed.). Lund: Studentlitteratur.

Kvande, E. (2003). Doing Gender in Organizations - Theoretical Possibilities and Limitations. In E. Gunnarsson, S. Andersson, A. Vänje Rosell, A. Lethto, \& M. Salminen-Karlsson (Eds.), Where have all the structures gone (pp. 15-43). Stockholm: Center for Women's Studies.

Landström, H. (2010). Entreprenörskapets Rötter. Lund: Studentlitteratur.

Lewis, P. (2006). The Quest for Invisibility: Female Entrepreneurs and the Masculine Norm of Entrepreneurship. Gender, Work \& Organization, 13(5), 453-469.

Lindgren, G. (1999). Klass, Kön och Kirurgi. Malmö: Liber.

Lindgren, M. (2000). Kvinnor i Friskolor - Om Kön, Entreprenörskap och Profession $i$ Identitetsskapande. Örebro: Forum För Småföretagsforskning.

Lindgren, M. (2002). Kvinnor och friskolor - kvinnliga entreprenörer och nya livsformer. In C. Holmquist \& E. Sundin (Eds.), Företagerskan - Om kvinnor och entreprenörskap. Stockholm: SNS Förlag.

Lindgren, M. (2008). Maskulint, Feminint, Entreprenöriellt - Könsstämpling av Branscher och Professioner. In P. Larsson, U. Göransson, \& M. Lagerholm (Eds.), Sesam Öppna Dig! Forskarperspektiv på Kvinnors Företagande: Vinnovarapport 2008:20.

Ljunggren, E., \& Alsos, G. A. (2007). Media expressions of entrepreneurs: presentations and discourse of male and female entrepreneurs in Norway. In C. Henry \& K. Johnston (Eds.), Promoting female entrepreneurship: Implications for education, training and policy. London: Routledge.

Lofstedt, J. (2003). Gender and the Veterinary Medicine. The Canadian Veterinary Journal, 44(July), 533-535.

Lorber, J. (2005). Breaking the bowls: Degendering and feminist change: WW Norton New York.

Lowe, P. (2010). A Public or Private Profession. Veterinary Record: Journal of the British Veterinary Association, 166(7), 211-212.

Lundström, A., \& Sundin, E. (Eds.). (2008). Perspektiv på Förnyelse och Enterprenörskap: FSF 2008:1.

Lönnbring, G. (2003). Självständighetens livsformer. Kvinnoföretagande på värmländsk landsbygd. (Doktorsavhandling), Karlstad University Karlstad.

Lönnbring, G. (2004). Kvinnoföretagande på landsbygden - olika former av självständighet. Arbetsmarknad och arbetsliv, 10(4), 219-232.

Lövgren, A. (2012, 2012-09-17). Riskkapitalets Nya Patient. Dagens Industri.

Maines, R. (2007). Why Women Become Veterinarians but Not Engineers. Chronicle of Higher Education, 53(30).

Manimalis. (2009) Manimalisrapporten.

Marlow, S. (2002). Women and self-employment: a part of or apart from theoretical construct? The International Journal of Entrepreneurship and Innovation, 3(2), 83-91.

Marlow, S. (2014). Exploring future research agendas in the field of gender and entrepreneurship. International Journal of Gender and Entrepreneurship, 6(2), 102-120. 
Marlow, S., \& Carter, S. (2004). Accounting for Change: Professional Status, Gender Disadvantage and Self-employment. Women In Managment Review, 19(1), 5-17.

McMurray, R. (2011). The struggle to professionalize: An ethnographic account of the occupational position of Advanced Nurse Practitioners. Human Relations, 64(6), 801-822.

Miller, W., Kerr, B., \& Reid, M. (1999). A National Study of Gender-Based Occupational Segregation in Municipal Bureaucracies: Persistence of Glass Walls? Public Administration Review, 59(3), 218-230.

Mintzberg, H. (1980). Structure in 5's: A Synthesis of the Research on Organization Design. Management science, 26(3), 322-341.

Mirchandani, K. (1999). Feminist insight on gendered work: New directions in research on women and entrepreneurship. Gender, Work \& Organization, 6(4), 224-235.

Molander, A., \& Terum, L. I. (2008). Profesjonsstudier - en Introduksjon. In A. Molander \& L. I. Terum (Eds.), Profesjonsstudier. Oslo: Universitetsforlaget.

Montin, S. (2007). Moderna Kommuner. Malmö: Liber.

Morrison, A. (2006). A contextualisation of entrepreneurship. International Journal of Entrepreneurial Behaviour \& Research, 12(4), 192-209.

Morrison, A. M., \& Von Glinow, M. A. (1990). Women and Minorities in Management. American Psychologist, 45(2), 200-208.

Mueller, S. L. (2007). Gender-based Income Disparity Among Self-employed Professionals. Journal of Enterprising Communities: People and Places in the Global Economy, 1(4), 293-307.

Murphy, R. (1984). The Structure of Closure: A Critique and Development of the Theories of Weber, Collins and Parkin. The British Journal of Sociology, 35(4), 547-567.

Murphy, R. (1986). Weberian Closure Theory: A Contribution to the Ongoing Assessment. The British Journal of Sociology, 37(1), 21-41.

Nationalencyklopedin. (2012). Hushållningssällskap. Retrieved 2012-03-01, from http://www.ne.se/lang/hushållningssällskap

Nationalencyklopedin. (2016). Sveriges lantbruksuniversitet. Retrieved 2016-03-25, from http://www.ne.se/uppslagsverk/encyklopedi/lång/sveriges-lantbruksuniversitet

Nentwich, J. C., \& Kelan, E. K. (2014). Towards a Topology of 'Doing Gender': An Analysis of Empirical Research and Its Challenges. Gender, Work \& Organization, 21(2), 121-134.

Neurath, C., \& Almgren, J. (2014, 2014-08-30). Bransch i Motvind. Svenska Dagbladet/SvD Näringsliv. Nordgren, M. (2000). Läkarprofessionens Feminisering - Ett Köns- och Maktperspektiv. (Doktorsavhandling), Stockholm University, Stockholm.

Nylén, U. (2005). Att presentera kvalitativa data - framställningsstrategier för empiriredovisning. Malmö: Liber.

Olofsson, M. (2010, 2010-03-15). Aktuella Frågor: Fler Kvinnor bör Driva Företag. Sydsvenskan.

Olson, D. R. (1996). Towards a psychology of literacy: on the relations between speech and writing. Cognition, 60(1), 83-104.

Parkin, F. (1974). Strategies of Social Closure in Class Formation. In F. Parkin (Ed.), The Social Analysis of Class Structure. London: Tavistock Publications.

Parkin, F. (1979). Marxism and class theory: A bourgeois critique. London: Tavistock Publications.

Pettersson, K. (2002). Företagande män och osynliggjorda kvinnor: diskursen om Gnosjö ur ett könsperspektiv. (Doktorsavhandling), Uppsala universitet, Uppsala.

Pettersson, K., \& Heldt-Cassel, S. (2014). Women tourism entrepreneurs: doing gender on farms in Sweden. Gender in Management: An International Journal, 29(8), 487-504.

Powell, A., Bagilhole, B., \& Dainty, A. (2009). How women engineers do and undo gender: consequences for gender equality. Gender, Work \& Organization, 16(4), 411-428.

RCVS. (2012a) The 2010 RCVS Survey of the UK Veterinary and Veterinary Nursing Professions.

RCVS. (2012b) RCVS Facts: The Annual Report of the Royal College of Veterinary Surgeons: Part 2.

Regeringens proposition. (1990/91) Utveckling av Offentlig Sektor - Gemensamma Frågor. 1990/91: 100 Civildepartementet 
Rennstam, J., \& Wästerfors, D. (2015). Från stoff till studie. Om analysarbete i kvalitativ forskning. Lund: Studentlitteratur.

Ridgeway, C. L., \& Correll, S. J. (2004). Unpacking the Gender System - A Teoretical Perspective on Gender Beliefs and Social Relations. Gender \& Society, 18(4), 510-531.

Ridgeway, C. L., \& Smith-Lovin, L. (1999). The Gender System and Interaction. Annual Review of Sociology, 25, 191-216.

Riksdagens Revisorer. (2002) Villkoren för veterinär verksamhet. 2002/03:4

Riska, E. (2010). Women in the Medical Profession; International Trends. In E. Kuhlmann \& E. Annandale (Eds.), The Palgrave handbook of gender and healthcare. Basingstoke: Palgrave Macmillan.

Risman, B. J. (2009). From doing to undoing: Gender as we know it. Gender and Society, 23(1), 81-84. Rosell, A. (2013). Stora löneskillnader mellan män och kvinnor. Veterinärmagazinet, 22-26.

Saco. (2004) Saco medlemsstatistik 2004-12-31.

Saco. (2014) Saco medlemsstatistik 2014-12-31.

San Román, S., \& Cortina, R. (2006). Women and teaching: Global perspectives on the feminization of a profession: Palgrave Macmillan.

Saunders, M., Lewis, P., \& Thornhill, A. (2007). Research Methods for Business Students (5 ed.). Essex: Pearson Education.

Schumpeter, J. A. (1934/1994). The theory of economic development. In R. Swedberg (Ed.), Schumpeter: Om skapande förstörelse och entreprenörskap. Stockholm: Nordstedts.

Schöön, L. (2014). En modern svensk ekonomisk historia. Lund: Studentlitteratur.

Sehested, K. (2002). How new public management reforms challenge the roles of professionals. International Journal of Public Administration, 25(12), 1513-1537.

Shane, S. (2000). Prior Knowledge and the Discovery of Entrepreneurial Opportunities. Organization Science, 11(4), 448-469.

Silius, H. (1989). Könssegregering i Ingenjörs-, Jurist- och Läkarkårerna. In H. Silius (Ed.), Kvinnor i Mansdominerade Yrken. Åbo: Institutet för Kvinnoforskning vid Åbo Akademi.

Sköld, B. (2013). Strukturerna och företagandet: En longitudinell studie av kvinnors och mäns företagande i spåren av offentlig sektors omvandling. (Licentiatavhandling), Linköping universitet, Linköping.

Sköld, B. (2015). Vad hände? Kvinnors företagande och de strukturella villkoren. (Doktorsavhandling), Linköpings universitet, Linköping.

Sköld, B., \& Tillmar, M. (2015). Resilient gender order in entrepreneurship: the case of Swedish welfare industries. International Journal of Gender and Entrepreneurship, 7(1), 2-26.

Slater, M. R., \& Slater, M. (2000). Women in Veterinary Medicine. Journal of the American Veterinary Medical Association, 217(4), 472-476.

Smith, C. A. (2002). Gender and Work: What Veterinarians Can Learn From Research About Women, Men, and Work. Journal of the American Veterinary Medical Association, 220(9), 1304-1311.

Sommestad, L. (1992). Från Mejerska till Mejerist - En Studie av Mejeriyrkets Maskuliniseringsprocess. (Doktorsavhandling), Uppsala University, Uppsala.

SOU. (1981:57) Djurens hälso- och sjukvård. Stockholm: Statens Offentliga Utredningar

SOU. (1990:44) Demokrati och Makt i Sverige. Stockholm: Statens Offentliga Utredningar

SOU. (2007:24) Veterinär Fältverksamhet i Nya Former. Stockholm: Statens Offentliga Utredningar

Statens Veterinärmedicinska Anstalt. (2015). Mer om SVA. Retrieved 2015-04-08, from http://www.sva.se/om-sva/mer-om-svas-verksamhet

Statistiska Centralbyrån. (2010) Tätorter 2010.

Statistiska Centralbyrån. (2014) Utbildningsstatistisk Årsbok.

Stenbacka, S. (2008). Vardagsliv och jämställdhet - landsbygd i förändring. In B. Johansson (Ed.), Ska hela Sverige leva? Stockholm: Formas Fokuserar.

Sternberg, R., \& Wennekers, S. (2005). Determinants and effects of new business creation using global entrepreneurship monitor data. Small Business Economics, 24(3), 193-203. 
Stevenson, L. (1990). Some methodological problems associated with researching women entrepreneurs. Journal of Business Ethics, 9(4-5), 439-446.

Steyaert, C. (2007). 'Entrepreneuring'as a conceptual attractor? A review of process theories in 20 years of entrepreneurship studies. Entrepreneurship and Regional Development, 19(6), 453477.

Sundin, E. (1995a). Kvinnors Företagsamhet - En Avspegling av Samhället. In E. Sundin (Ed.), Pengarna och Livet - Perspektiv på Kvinnors Företagande. Stockholm: NUTEK B 1995:3.

Sundin, E. (1995b). Teknik och Organisation i Teori och Praktik. Lund: Nerenius \& Santérus Förlag AB.

Sundin, E. (2002). Företagandets Manliga Prägling - Orsaker och Konsekvenser. In C. Holmquist \& E. Sundin (Eds.), Företagerskan - Om Kvinnor och Entreprenörskap. Stockholm: SNS Förlag.

Sundin, E. (2003). Små Företag - Lösning på Vad och För Vem? In C. Von Otter (Ed.), Ute och Inne i Svenskt Arbetsliv: Arbetslivsinstitutet.

Sundin, E. (2009). Det dolda samhällsentreprenörskapet - Omsorgsmotiv i småföretag. In M. Gawell, B. Johannisson, \& M. Lundqvist (Eds.), Samhällets entreprenörer - En forskarantologi om samhällsentreprenörskap. Stockholm: KK Stiftelsen.

Sundin, E. (2010). Vem Är Egentligen Företagare. In N. Brunsson (Ed.), Företagsekonomins Frågor. Stockholm: SNS Förlag.

Sundin, E. (2011). Entrepreneurship and the reorganization of the public sector: A gendered story. Economic and Industrial Democracy, $0143831 \times 10392394$.

Sundin, E., \& Holmquist, C. (1989). Kvinnor som Företagare - Osynlighet, Mångfald, Anpassning. Malmö: Liber.

Sundin, E., \& Holmquist, C. (2015). 25 år med kvinnors företagande - Från osynligt till drivkraft för tillväxt: Tillväxtverket.

Sundin, E., \& Tillmar, M. (2008). A Nurse and a Civil Servant Changing Institutions: Entrepreneurial Processes in Different Public Sector Organizations. Scandinavian Journal of Management, 24, 113-124.

Sundin, E., \& Tillmar, M. (2010a). Masculinisation of the Public Sector; Local-level Studies of Public Sector Outsourcing in Elder Care. International Journal of Gender and Entrepreneurship, 2(1), 49-67.

Sundin, E., \& Tillmar, M. (2010b). Varför Ska Kvinnor Starta Företag inom Vård och Omsorg? In E. Sundin, M. Tillmar, \& M. Renstig (Eds.), Varför Ska Kvinnor Starta Företag inom Vård och Omsorg? Stockholm: Tillväxtverket.

Svensk Djursjukvård. (2014) Branschrapport.

Svensk Djursjukvård. (2015). Om SLA Svensk Djursjukvård. Retrieved 2015-04-09, from http://svenskdjursjukvard.se/om-sla/

Svensson, L. G. (2003). Professionella villkor och värderingar: en sociologisk studie av akademiker $i$ 1990-talets Sverige: Göteborg: Sociologiska institutionen.

Svensson, L. G., \& Evetts, J. (Eds.). (2010). Sociology of Professions: Continental and Anglo-saxon Traditions. Göteborg: Bokförlaget Daidalos AB.

Sveriges Kommuner och Landsting. (2015). Kommungruppsindelning. Retrieved 2015-12-15, from http://skl.se/tjanster/kommunerlandsting/faktakommunerochlandsting/kommungruppsinde Ining.2051.html

Sveriges lantbruksuniversitet. (2015). Retrieved 2015-04-09, from http://www.slu.se/sv/

Sveriges Veterinärförbund. (2015). Det här är Sveriges Veterinärförbund. Retrieved 2015-04-09, from http://www.svf.se/sv/Forbundet/Det-har-ar-Sveriges-Veterinarforbund/

Thomas, R., \& Davies, A. (2002). Gender and new public management: Reconstituting academic subjectivities. Gender, Work and Organization, 9(4), 372-397.

Thomsson, H. (2010). Reflexiva Intervjuer. Lund: Studentlitteratur.

Thurén, B.-M. (1996). Om styrka, räckvidd och hierarki, samt andra genusteoretiska begrepp. Tidskrift för genusvetenskap(3-4), sid 69-85.

Tillmar, M. (2007). Gendered Small-Business Assistance: Lessons from a Swedish Project. Journal of European Industrial Training, 21(1), 84-99. 
Tillmar, M. (2009). No Longer So Strange? (Dis)Trust in Municipality-Small Business Relationships. Economic and Industrial Democracy, 30(3), 401-428.

Tillväxtverket. (2012a) Entreprenörskapsbarometern - attityder till företagande i Sverige.

Tillväxtverket. (2012b) Kvinnors och Mäns Företagande - Företagens Villkor och Verklighet. Stockholm:

Tillväxtverket. (2015). Kvinnors företagande ökar. Retrieved 2015-02-09, from http://www.tillvaxtverket.se/huvudmeny/faktaochstatistik/foretagande/kvinnor.4.2fb8c830 14597db7ce977f2f.html

Treanor, L., \& Marlow, S. (2016). The Limiting Effects of a Gendered Professional Context on Women's Entrepreneurial Activity: The Case of the Feminising UK Veterinary Profession. Paper presented at the Gender, Work \& Organization, Keele University, UK.

Trost, J. (2005). Kvalitativa Intervjuer. Lund: Studentlitteratur.

Ulfsdotter Eriksson, Y. (2006). Yrke, status \& genus: en sociologisk studie om yrken på en segregerad arbetsmarknad: Department of Sociology Sociologiska institutionen.

Universitets- och högskolerådets antagningsstatistik. (2015). Retrieved 2015-04-13, from http://statistik.uhr.se/

Uppsala Tingsrätt. (2009-03-30) Dom.

Wahl, A., Holgersson, C., Höök, P., \& Linghag, S. (2011). Det Ordnar Sig - Teorier om Organisation och Kön. Lund: Studentlitteratur.

Walby, S. (1986). Theorizing Patriarchy. Cambridge: Polity.

Waldenström, C., \& Westholm, E. (2006). En strategi för landsbygdsforskning - underlag till landbygdskommittén. Stocholm Fritzes.

Welter, F. (2011). Contextualizing Entrepreneurship - Conceptual Challenges and Ways Forward. Entrepreneurship Theory and Practice, 35(1), 165-184.

West, C., \& Fenstermaker, S. (1995). Doing Difference. Gender and Society, 9(1), 8-37.

West, C., \& Zimmerman, D. H. (1987). Doing Gender. Gender \& Society, 1(2), 125-151.

Westholm, E. (2008). Vad menas egentligen med landsbygd. In B. Johansson (Ed.), Ska hela Sverige leva? Stockholm: Formas Fokuserar.

Vetenskapsrådet. (2002) Forskningsetiska principer inom humanistisk-samhällvetenskaplig forskning. Veterinärmagazinet. (2012-01-11). Ny Veterinärkedja Lanseras.

Wetterberg, C. (1992). Från patriarkat till genussystem - och vad kommer sedan? Kvinnovetenskaplig Tidskrift(3), 34-48.

Winston Castro, F. (1992). Bortom den nya medelklassen - Durkheim och de moderna professionella yrkesgrupperna. (Doktorsavhandling), Götebord universitet, Göteborg.

Witz, A. (1988). Patriarchal Relations and Patterns of Sex Segregation in the Medical Division of Labour. In S. Walby (Ed.), Gender Segregation at Work. Philadelphia: Open University Press.

Witz, A. (1992). Professions and Patriarchy. London Routledge.

VMCAS Statistics. (2012). Retrieved 2013-04-24, from http://www.aavmc.org/Public-Data/VMCASStatistics.aspx

Zahra, S. A. (2007). Contextualizing theory building in entrepreneurship research. Journal of Business Venturing, 22(3), 443-452.

Åsberg, C. (1998). Debatten om Begreppen - "Genus" i Kvinnovetenskaplig Tidskrift 1980-1998. Kvinnovetenskaplig Tidskrift(2), 29-41.

Öberg, P. (2011). Livshistorieintervjuer. In G. Ahrne \& P. Svensson (Eds.), Handbok i kvalitativa metoder. Malmö: Liber AB.

Östensson, K. (2010). Från Manligt till Kvinnligt. In L.-E. Appelgren, I. Jämte, \& K. Östensson (Eds.), Veterinär - Yrke i Förvandling: Sveriges Veterinärförbund 150 år Jubileumsutgåva. 


\section{Intervjuguide}

Företag:

Datum:
IP:

Tid:

Plats:

\section{Information om avhandlingen etc.}

Går det bra om jag spelar in den här intervjun?

Syfte att beskriva och analysera villkoren för kvinnors företagande inom veterinärsektorn $i$ Östergötland.

Ambition att tala med alla kvinnor som är företagare inom veterinärsektorn $i$ Östergötland har identifierat ett 10-tal. Jag vill försöka fä en övergripande bild av villkoren för företagande.

Jag kommer inte att publicera något där du nämns vid namn utan att först få godkännande för detta. Du kan avbryta när som helst.

\section{Korta bakgrundsfakta}

- Företagare alt. Veterinär i släkten?

- Egna djur

- Utbildning

- Tidslinje från utbildning fram tills idag (olika tjänster etc.)

Val av yrke

Val av att starta eget

\section{Berätta om företaget}

- När startade

- Bolagsform

- Vem står som ägare (om flera: vem gör vad och varför)

- Antal anställda (utbildning, tjänstetyp (Hel-, deltid)

- Verksamhetsinriktning (djurslag)

- Typer av behandlingar som genomförs 
Bilaga 1

Hur mycket tid läggs på företaget (skötseln av verksamheten)

Viktiga kringverksamheter (foder, kremering, kloklippning, vaccination - vad är lönsamt?)

Samarbetspartners/Konkurrenter

Försäkringar

Omsättning och lönsamhet

Hur viktigt är det med teknisk utrustning?

Övrigt

Andra engagemang förutom att driva verksamheten, föreningar etc.

\section{Avslutningsvis}

Något du vill tillägga? Återkomma om jag kommer på något ytterligare att fråga om? 


\section{Statliga myndigheter}

De statliga myndigheterna som är involverade i den svenska veterinärsektorn är Jordbruksverket, Distriktsveterinärorganisationen (DVO), Länsstyrelser, Livsmedelsverket, Ansvarsnämnden för djurens hälso- och sjukvård samt Statens veterinärmedicinska anstalt (SVA). Som statlig myndighet räknas även Sveriges Lantbruksuniversitet (SLU) vilken dock går att läsa om i kapitel 2. Av dessa är det Jordbruksverket, Livsmedelsverket samt Länsstyrelserna som har någon form av tillsynsansvar gällande de svenska veterinärerna.

Myndighetsstrukturen för den svenska veterinärprofessionen kan beskrivas som splittrad organisatoriskt; både horisontellt och vertikalt (SOU, 2007:24). I ett horisontellt perspektiv är ansvaret för djur- respektive livsmedelsfrågor delat mellan Jordbruksverket och Livsmedelsverket. I ett vertikalt perspektiv är länsstyrelserna regionalt ansvariga för tillsynen av veterinär yrkesutövning, samtidigt som Jordbruksverket är nationellt ansvarig för denna tillsyn.

\section{J ordbruksverket}

Jordbruksverket är en förvaltningsmyndighet inom jordbruket samt regeringens expertmyndighet på det jordbruks- och livsmedelspolitiskaområdet (Jordbruksverket, 2015). Jordbruksverket har en central tillsyn av veterinär yrkesutövning och dessutom ansvaras för smittskyddsorganisationen inom djurhållningen och för att lagstiftning om smittsamma djursjukdomar följs. Utöver detta utfärdar Jordbruksverket även legitimationer för de sex yrken inom djurens hälso-och sjukvård som är behörighetsreglerade och som går under det gemensamma epitetet djurhälsopersonal, däribland legitimation för veterinärer ${ }^{47}$. Uppdraget om central tillsyn av veterinär yrkesutövning ligger under avdelningen för djurskydd och hälsa (Chef Distriktsveterinärernas huvudkontor, 2010-04-14). Jordbruksverket är även chefsmyndighet för distriktsveterinärerna, vars organisation ligger som en särskild division inom myndigheten (Jordbruksverket, 2015).

\section{Länsstyrelserna}

I Sverige finns 21 länsstyrelser (SOU, 2007:24) som i egenskap av regionala, statliga myndigheter arbetar utifrån den grundläggande uppgiften att vara statens företrädare i regionerna och samordnare i de frågor som staten ålagt dem. I varje länsstyrelse finns en eller flera länsveterinärer, som har myndighetsuppgifter på regional nivå när det

\footnotetext{
47 Övriga yrken inom kategorin djurhälsopersonal är: legitimerade djursjukskötare, godkänd legitimerad sjuksköterska, godkänd legitimerad sjukgymnast, godkänd legitimerad tandläkare, godkänd hovslagare. Det finns även de som yrkesmässigt arbetar inom djurens hälso-och sjukvård men som inte anses tillhöra djurhälsopersonal: djurvårdare, hovslagare utan godkännande, fysioterapeuter, hästtandvårdare, massörer, equiterapeuter, biomedicinska analytiker är några exempel på dessa.
} 
gäller att exempelvis säkerställa och samordna veterinära resurser i länet. Länsstyrelserna har även ansvar för förebyggande smittskydd för djur, samt leder och samordnar bekämpning av vissa allvarliga smittsamma djursjukdomar. Länsstyrelserna lyder under finansdepartementet (SOU, 2007:24).

\section{Livsmedelsverket}

Livsmedelsverket är en central förvaltningsmyndighet för livsmedelsfrågor. Verket sorterar under Landsbygdsdepartementet och dess övergripande mål är bland annat att konsumenterna ska få säkra livsmedel men även att säkerställa redlighet i livsmedelshantering. Inom verksamhetsgrenen "Säkra Livsmedel" ligger resultatområdet köttbesiktning. Denna köttbesiktning utförs i huvudsak av besiktningsveterinärer anställda av Livsmedelsverket vid landets slakterier. Tillsynsoch kontrollverksamheten finansieras i huvudsak genom avgifter (SOU, 2007:24).

SVA

Statens veterinärmedicinska anstalt (SVA) är en veterinärmedicinsk expert- och uppdragsmyndighet som ska verka för god djur- och folkhälsa. SVA är en myndighet under Näringsdepartementet och kan beskrivas som ett kunskapscenter specialiserat på djurs sjukdomar och smittämnen samt hur de sprids - mellan djur, till människan och i miljön. Generaldirektören för SVA tillsätts av regeringen. Med uppgift att utöva insyn över myndighetens verksamhet finns ett insynsråd kopplat till SVA. Representanterna kommer från skilda håll såsom Folkhälsomyndigheten, LRF, SLU, Jordbruksverket, Evidensia Djursjukvård $\mathrm{AB}$ etc. Avsikten med insynsrådet är att förstärka den demokratiska insynen och därmed verka för medborgarnas möjligheter till inflytande (Statens Veterinärmedicinska Anstalt, 2015).

\section{Ansvarsnämnden för djurens hälso- och sjukvård}

Till ansvarsnämnden kan djurägare, men även tillsynsmyndigheter, göra anmälningar om de anser att en person som tillhör djurhälsopersonalgruppen i sin yrkesutövning ansvarar för felbehandling av djur eller felaktigt intygande. Ansvarsnämnden prövar, på uppdrag av Jordbruksverket, även frågor om återkallelse av legitimation/godkännande samt begränsningar i förskrivningsrätten (Ansvarsnämnden för djurens hälso- och sjukvård, 2015). 


\section{Övriga aktörer}

\section{Sveriges Veterinärförbund}

Sveriges veterinärförbund (SVF) bildades 1860 och är en intresseorganisation och ett yrkesförbund för veterinärer och veterinärstuderande. Syftet med verksamheten är bland annat att främja veterinäryrkets utveckling, den vetenskapliga utvecklingen inom det veterinärmedicinska området samt medlemmarnas sociala och ekonomiska intressen. Under SVF:s paraply residerar även Anställda Veterinärers Förening (AVF), Företagande Veterinärers Förening (FVF) samt Sveriges Veterinärmedicinska Sällskap (SVS). Förbundet är anslutet till Saco (Sveriges Akademikers Centralorganisation). SVF tar bland annat fram branschregler såsom etiska regler för veterinär verksamhet, regler för intygsskrivning samt för djurmottagningar. De verkar även för att upprätthålla en god och värdig anda inom veterinärkåren. Förbundet är även ansvarigt för en årligt arrangerad veterinärkongress samt utgivningen av tidskriften Svensk Veterinärtidning (Sveriges Veterinärförbund, 2015).

\section{Svensk Djursjukvård}

Svensk Djursjukvård är djursjukvårdsföretagens branschorganisation. Medlemsföretagen (cirka 200 stycken) bedriver hälso- och sjukvård under veterinärmedicinskt ansvar för sport- och sällskapsdjur. Organisationen verkar för en långsiktig utveckling i branschen och företräder sina medlemmar i kontakten med såväl myndigheter som beslutsfattare. Medlemsföretagen styr organisationen genom beslut och val på medlemsmöten där varje företag har en röst (Svensk Djursjukvård, 2015).

\section{AniCura}

Djursjukvårdskoncernen AniCura (tidigare Djursjukhusgruppen) etablerades 2011 i Sverige då fyra större djursjukhus lokaliserade i Stockholm, Göteborg samt Falun gick samman och bildade djursjukhusgruppen. Därefter har etablering även skett i Norge 2012 samt i Danmark 2013. Vården är främst inriktad på sällskapsdjur och finns i Sverige att tillgå via 34 verksamheter. AniCura ägs av medarbetare, stiftelsen Djursjukhus i Stor-Stockholm, det svenska investmentbolaget Fidelio Capital samt Nordic Capital (AniCura, 2015).

\section{Evidensia djursjukvård}

Evidensia Djursjukvård etablerades 2012 då några Djursjukhus och kliniker belägna i Helsingborg, Malmö, Strömsholm och Stockholm gick samman. Evidensia har inriktning mot vård av sällskapsdjur men även häst. Förutom verksamhet i Sverige (via ett 90-tal djursjukhus och kliniker) så är Evidensia även etablerat i Norge, 
Danmark och Finland. Evidensia Djursjukvård ägs av Stiftelsen Svensk Djursjukvård, Stiftelsen Strömsholm Djursjukvård, Private Equity-bolaget EQT samt Evidensias ledning och nyckelmedarbetare (Evidensia, 2015).

\section{Vettris}

Veterinärkedjan Vettris startades upp 2012. I samarbete med zoo-butikskedjan Arken Zoo var Vettris inspirerat av det i Storbritannien vanliga konceptet vet-in-shop (då det finns en veterinärmottagning $i$ eller i anslutning till en zoo-butik). Avsikten vara att etablera veterinärkedjan dels genom uppköp av befintliga veterinärkliniker, dels genom uppstart av nya kliniker. Till detta lades även, ett sedan tidigare ej praktiserat koncept i den svenska veterinärsektorn, erbjudanden av franchise-avtal till veterinärer eller andra villiga att etablera en klinik under Vettris varumärke. Bakom Vettris står investmentbolaget Braganza, sedan tidigare ägare till bland andra Arken Zoo i Sverige (Veterinärmagazinet). 


\section{Dokumentstudie}

\section{Nationellt}

Genomgång av hemsidor samt i vissa fall årsredovisningar

Jordbruksverket

Livsmedelsverket

Statens Veterinärmedicinska Anstalt (SVA)

Ansvarsnämnden för djurens hälso- och sjukvård

Sveriges lantbruksuniversitet (SLU)

$>$ Distriktsveterinärorganisationen (DVO)

Sveriges Veterinärförbund

Veterinärer i Sverige (ViS)

Svensk Djursjukvård

> Länsstyrelsen i Östergötland

Agria Djurförsäkring

Evidensia djursjukvård

AniCura

Vettris

Officiella statliga dokument

> Regeringens proposition 1990/91: 100. Utveckling av Offentlig Sektor Gemensamma Frågor. Civildepartementet

SOU. (1990:44) Demokrati och Makt i Sverige. Stockholm: Statens Offentliga Utredningar

> SOU. (1997:83) Om Makt och Kön - I Spåren av Offentliga Organisationers Omvandling. Stockholm: Statens Offentliga Utredningar

> SOU. (1981:57) Djurens hälso- och sjukvård. Stockholm: Statens Offentliga Utredningar 
> SOU. (1992:88) Veterinär verksamhet: Behov, Organisation och Finansiering. Betänkande. Stockholm: Statens Offentliga Utredningar

> SOU. (2007:24) Veterinär Fältverksamhet i Nya Former. Stockholm: Statens Offentliga Utredningar

Regeringens proposition 2008/09:211. En ny organisation för veterinär service och vid utbrott av smittsamma djursjukdomar.

> Riksdagens Revisorer. (2002/03:4). Villkoren för veterinär verksamhet.

\section{Jubileumsböcker - Veterinärförbundet}

Hallgren, W. (1962). Svensk Veterinärhistoria i Ord och Bild: Allhems Förlag.

Appelgren, L.-E., Jämte, I., \& Östensson, K. (2010). Veterinär - Yrke i

Förvandling. Från manligt till kvinnligt, från ensamvarg till lagarbetare: Sveriges Veterinärförbund 150 år Jubileumsutgåva.

\section{Övrig statistik, rapporter och uppslagsverk}

Statistiska Centralbyråns årsböcker 1975-2005

> Statistiska Centralbyrån. (2010) Tätorter 2010.

Statistiska Centralbyrån. (2012) Hundar, katter och andra sällskapsdjur 2012.

Manimalis. (2009). Manimalisrapporten.

Saco. (2014). Saco medlemsstatistik 2014-12-31.

> Nationalencyklopedin. (2012). Hushållningssällskap. Retrieved 2012-03-01, from http:/ / www.ne.se/lang/hushållningssällskap

$>$ Nationalencyklopedin. (2016). Sveriges lantbruksuniversitet. Retrieved 201603-25, from http://www.ne.se/uppslagsverk/encyklopedi/lång/sverigeslantbruksuniversitet

> Universitets- och högskolerådets antagningsstatistik. (2015). Retrieved 201504-13, from http://statistik.uhr.se/

> Agria Djursförsäkring. (2012). Fakta om antal sällskapsdjur i Sverige 2012. Retrieved 2015-11-26, from http://www.agria.se/pressrum/pressmeddelanden-2013/scb-studie-2012-avantalet-sallskapsdjur/

$>$ Agria Djursförsäkring. (2013). Katten är det vanligaste sällskapsdjuret. Retrieved 2015-11-26, from http://www.agria.se/pressrum/pressmeddelanden-2013/katten-ar-detvanligaste-sallskapsdjuret/ 


\section{Branschtidningar}

> Svensk veterinärtidning 2001-2015

> Veterinärmagazinet 2013-2015

\section{Dagspress (exempel)}

> Göteborgs-posten. (1995-06-20). Veterinärförhandling strandad, p. 30.

> Göteborgs-posten. (1995-06-23). Ny organisation för veterinärer, p. 23.

$>$ Helsingborgs Dagblad. (1995-07-06). Bra system för föräldrar.

Helsingborgs Dagblad. (1995-07-01). Sveriges veterinärer rasar Jordbruksverkets nya regler beskrivs som "ett kaos".

\section{Svensk forskning}

> Hellberg, I. (1978). Studier i Professionell Organisation. En professionsteori Tillämpad på Veterinäryrket. Göterborg universitet, Göteborg.

$>$ Hellberg, I. (1990). The Swedish veterinary profession and the Swedish state (Vol. S. [174]-185): The formation of professions: knowledge, state and strategy / edited by Rolf Torstendahl and Michael Burrage 1990.

\section{I nternationellt}

\section{Statistik}

AVMA. (2012). Market Research Statistics - U.S Veterinarians. Retrieved 2013-04-09, from

https://www.avma.org/KB/Resources/Statistics/Pages/Market-researchstatistics-US-veterinarians.aspx?PF=1

> RCVS. (2012). The 2010 RCVS Survey of the UK Veterinary and Veterinary Nursing Professions.

$>$ RCVS Facts. (2012). The Annual Report of the Royal College of Veterinary Surgeons: Part 2.

$>$ VMCAS Statistics. (2012). Retrieved 2013-04-24, from http://www.aavmc.org/Public-Data/VMCAS-Statistics.aspx 
Helsingfors universitetsmuseum. (2011). Retrieved 2011-05-11, from http://www.museo.helsinki.fi/svenska/utstallningar/kvinnor_vid_universit etet/sjoberg_sve/sjoberg2_sve.htm

\section{Artiklar från branschspecifika tidskrifter}

$>$ Slater, M. R., \& Slater, M. (2000). Women in Veterinary Medicine. Journal of the American Veterinary Medical Association, 217(4), 472-476.

$>$ Smith, C. A. (2002). Gender and Work: What Veterinarians Can Learn From Research About Women, Men, and Work. Journal of the American Veterinary Medical Association, 220(9), 1304-1311.

$>$ Lofstedt, J. (2003). Gender and the Veterinary Medicine. The Canadian Veterinary Journal, 44(July), 533-535.

Lowe, P. (2010). A Public or Private Profession. Veterinary Record: Journal of the British Veterinary Association, 166(7), 211-212.

Felsted, K. E. (2000). Why do Women Earn Less? Veterinary Economics(October), 33-38.

\section{Internationell forskning}

$>$ Henry, C., Baillie, S., \& Treanor, L. (2010). Encouraging Women's Entrepreneurship in the Sciences: Women in Veterinary Medicine. In P. Wynarczyk \& S. Marlow (Eds.), Innovating Women: Contributions to Technological Advancement (Contemporary Issues in Entrepreneurship Research, Volume 1): Emerald Group Publishing Limited.

$>$ Irvine, L., \& Vermilya, J. R. (2010). Gender Work in a Feminized Profession The Case of Veterinary Medicine. Gender \& Society, 24(1), 56-82.

$>$ Henry, C., \& Treanor, L. (2010). Entrepreneurship education and veterinary medicine: enhancing employable skills. Education + Training, 52(8/9), 607-623.

$>$ Henry, C., Treanor, L., \& Baillie, S. (2011). The challenges for female small business owners and managers: a consideration of the veterinary profession. In C. L. Cooper \& R. J. Burke (Eds.), Human Resource Management in Small Business - Achieving Peak Performance. Chelthenham UK: Edward Elgar.

> Henry, C., \& Treanor, L. (2012). The Veterinary Business Landscape: Contemporary Issues and Emerging Trends. In C. C. Perez-Marin (Ed.), A Bird's-Eye View of Veterinary Medicine: InTech. 
> Henry, C., \& Treanor, L. (2012). Exploring entrepreneurship education within veterinary medicine: can it be taught? Journal of Small Business and Enterprise Development, 19(3), 484-499.

Henry, C., Rushton, J., \& Baillie, S. (2016). Exploring the sustainability of small rural veterinary enterprise. Journal of Small Business and Enterprise Development, 23(1), 259-273. 
Bilaga 4

\section{Litteraturstudie:}

\section{Scopus; sökningar artiklar}

Sökningarna begränsades till nedanstående tidskrifter. Entreprenörskapstidskrifterna följer de som Karin Berglund fokuserat i sin forskningsöversikt över kvinnors företagande från 2007. Författaren har i sin tur baserat detta val på Jerome A Katz rangordning av entreprenörskapstidskrifter. Här gjordes ett tillägg av International Journal of Entrepreneurship and Small Business utifrån handledares rekommendation. Genustidskrifterna identifierades utifrån tidigare läsning och kollades därefter även av mot ISI ranking för att säkerställa kvalitet. Professionstidskrifterna identifierade genom sökningar på artiklar av kända professionsforskare som ex. Andrew Abbott. Dessa kollades även av mot ISI ranking för att säkerställa kvalitet.

Valda tidskrifter

- Gender, work and organisation

- Gender in management

- Gender and society

- Women in management review

- Journal of business venturing

- Small business economics

- Entrepreneurship theory and practice

- Entrepreneurship and regional development

- International journal of entrepreneurship and small business

- Journal of small business management

- Sociology

- American journal of sociology

- British journal of sociology

- Work and occupations

- Current sociology

- Sociological review

- International journal of health services

- Professions and professionalism

Settings för sökningar:

Date range: 2007-present

Document type: Article or review 
Subject area(s): Social Sciences and Humanities

Inställning för ordkombinationssträngar: Article title, abstract, keywords Inställning för tidskriftssträngar: Source title

Kombination med AND i samtliga fall

I några fall blev söksträngen för tidskrifter för lång och delades då upp i två delar. Dessa kombinerades då med OR.

Booleska kombinationer för sökningar, ämnesord

- Genus (G)

women* OR gender* OR femini* OR sex

- Entreprenörskap (E)

entrepren* OR "small business own*" OR self-employ* OR selfemploy*

OR "sme"

- Profession $(\mathrm{P})$

profession*

Sökkombinationer ämnesord

$$
\begin{aligned}
& G+E+P \\
& G+E \\
& E+P \\
& P+G
\end{aligned}
$$

\section{Manuellt; sökningar i Tidskrifter}

\section{International journal of gender and entrepreneurship}

Då denna tidskrift inte fanns kopplad till varken scopus eller web of science gick jag via databasen emerald insight. Värt att notera är att tidskriften startades 2009 och tidspannet för genomgång blir därmed 2009 nr 1 - 2013 nr 2. Sökningen gjordes i tre steg: 
Bilaga 4

1, Sökning inom tidskriften (enkel sökning)

Profession $^{*}=49$ träffar

2, Utdrag av table of content för samtliga nummer: vol 1 iss 1 - vol 5 iss

2. Dessa lästes av och kollades mot ovanstående träffar.

3, Titlar och abstrakt bedömdes utifrån innehåll i relation till avhandlingsområde. Utifrån detta gjordes urval till nettolista.

\section{Nordiske Organisasjonsstudier}

Översyn gjordes via tidningens egen sida och i tre steg:

1, Utdrag av innehållsförteckning gjordes för samtliga nummer mellan nr 1 2010-nr 1 2013, detta då tidskriften endast var tillgänglig digitalt från 2010.

2, År 2007-2010 gicks igenom manuellt på biblioteket

3, Titlar bedömdes utifrån innehåll i relation till avhandlingsområde. Utifrån detta gjordes urval till nettolista.

Libris; sökningar efter böcker/kapitel i böcker

Booleska kombinationer för sökningar; ämnesord

Engelska

(profession*) (women* OR gender* OR femini* OR sex) (entrepren* OR "small business own*" OR self-employ* OR selfemploy* OR "sme")

Svenska

(profession*) (kvinn* OR genus* Or femini* OR kön) (entrepren* OR företag*) 
$10 \quad \frac{7}{7}$

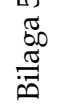

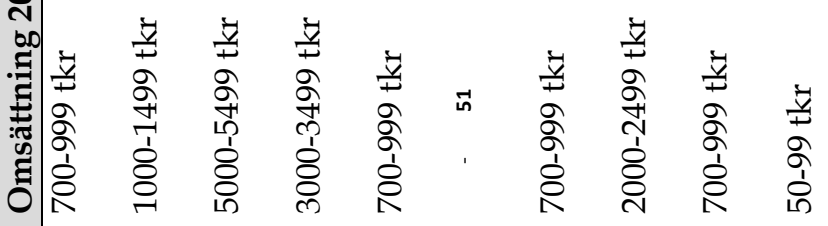

芠

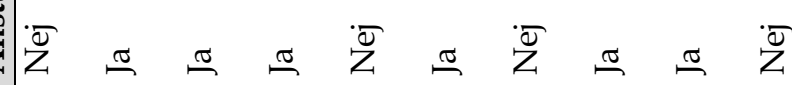

䔽

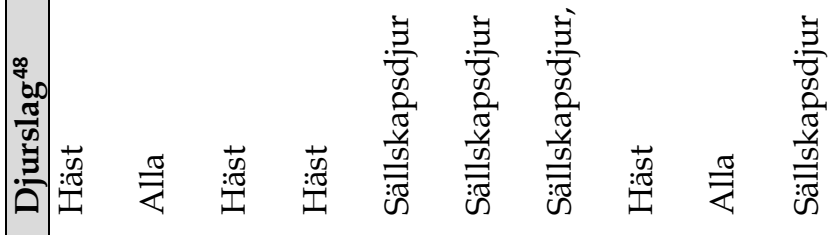

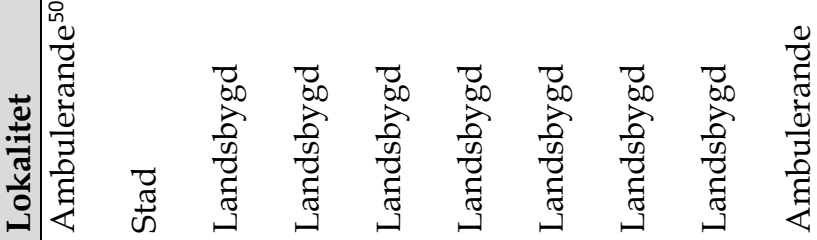

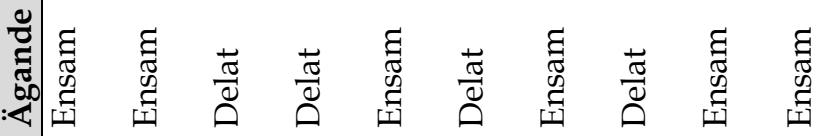

营

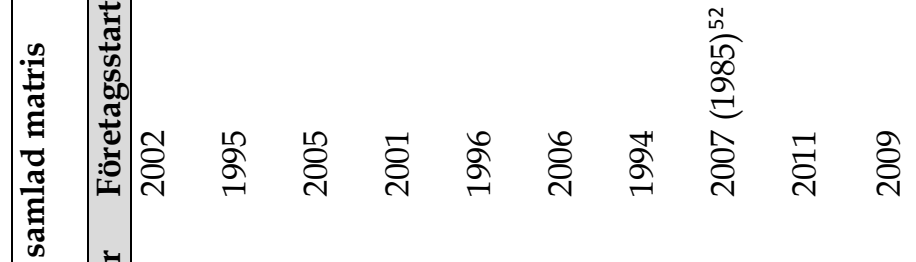

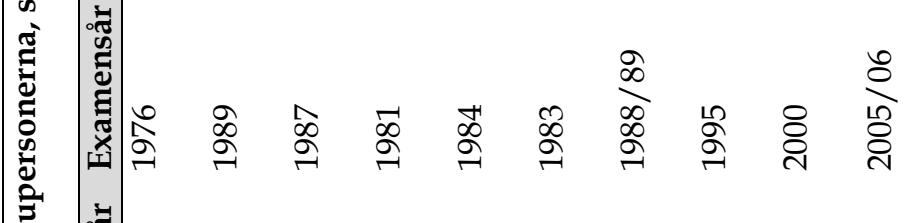

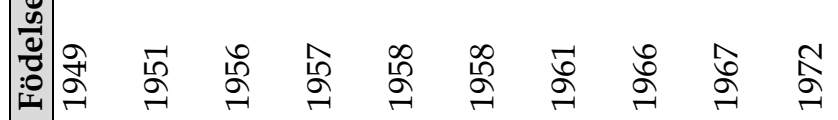

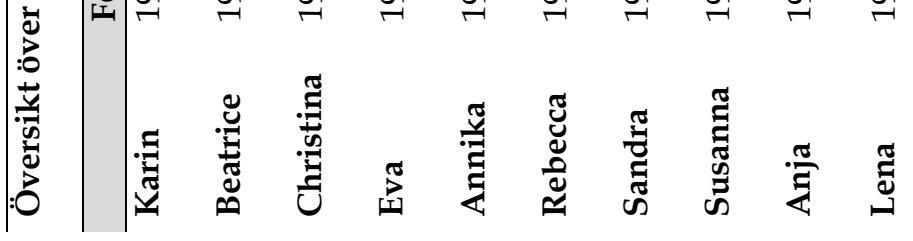


